February 2000

IMF Staff Country Report No. 00/22

\title{
Republic of Croatia: Selected Issues and Statistical Appendix
}

This Selected Issues and Statistical Appendix report on Republic of Croatia was prepared by a staff team of the International Monetary Fund as background documentation for the periodic consultation with this member country. As such, the views expressed in this document are those of the staff team and do not necessarily reflect the views of the Government of Republic of Croatia or the Executive Board of the IMF.

Copies of this report are available to the public from

International Monetary Fund • Publication Services

70019 th Street, N.W. - Washington, D.C. 20431

Telephone: (202) 623-7430 - Telefax: (202) 623-7201

Telex (RCA): 248331 IMF UR

E-mail: publications@imf.org

Internet: http://www.imf.org

Price: $\$ 15.00$ a copy

\section{International Monetary Fund Washington, D.C.}




\section{INTERNATIONAL MONETARY FUND \\ REPUBLIC OF CROATIA \\ Selected Issues and Statistical Appendix}

\section{Prepared by Rachel van Elkan, Riccardo Maggi (both EU1), Åke Lönnberg (MAE), and Jöel Toujas-Bernaté (PDR) \\ Approved by the European 1 Department}

December 21, 1999

Contents

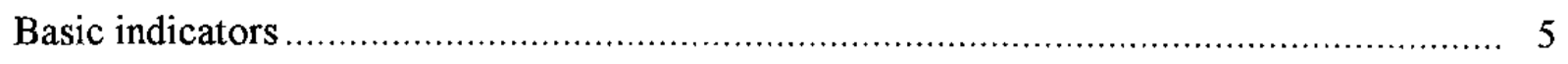

I. Trends in Croatia's Government Sector: A Cross-Country Comparison ……......... 6
A. Size of the Government Sector .............................................................. 6

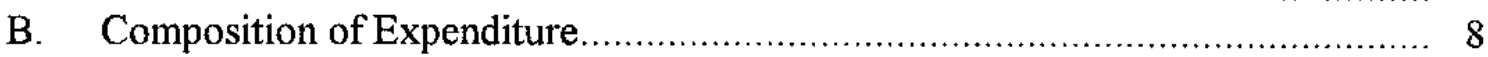
C. The Structure of General Government ....................................................... 14

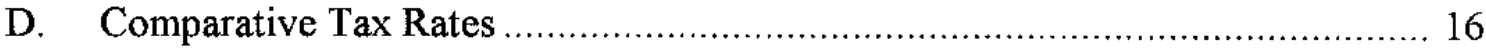

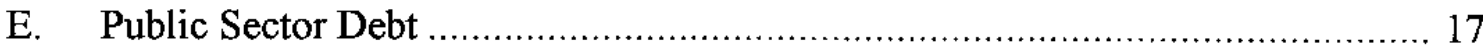

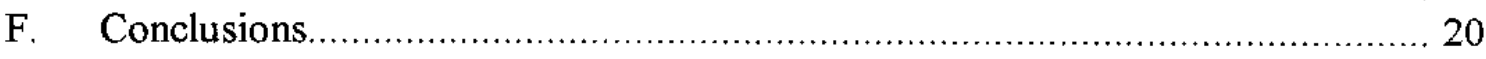

II. Recent Developments in Croatia's Financial Sector …......................................... 32

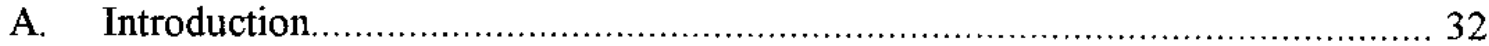

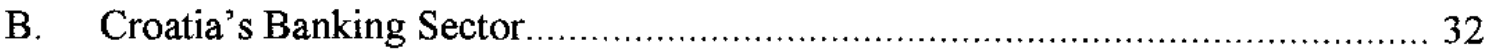
C. Other Financial Markets .................................................................................. 45

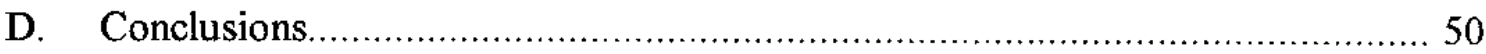

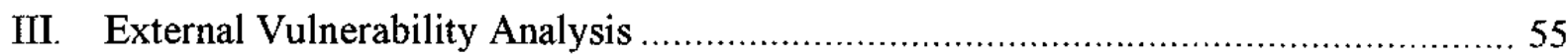

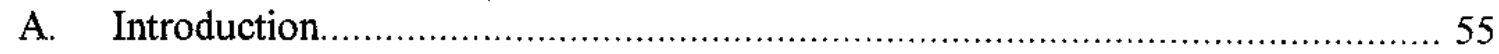

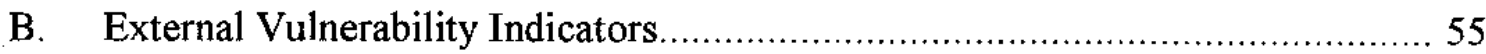

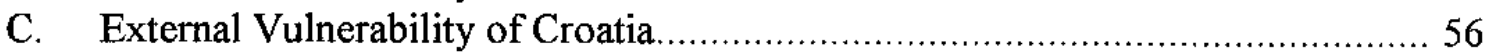

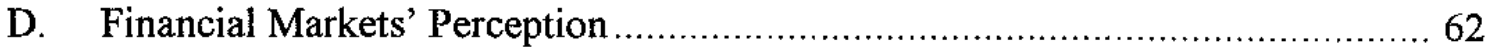

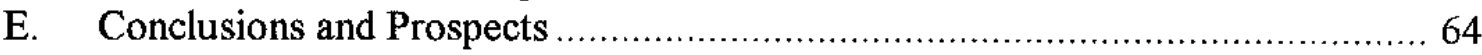

IV. Selected Aspects of Export Performance, Competitiveness, and Trade Policy ........... 67

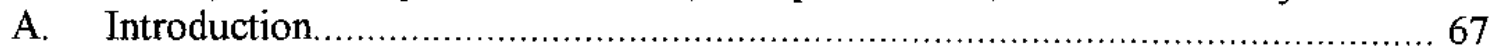

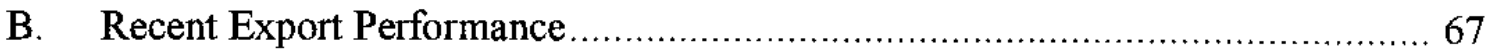




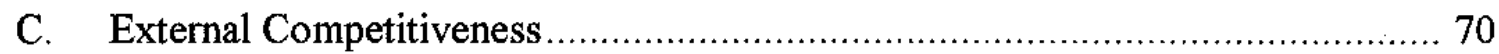

D. Trade Liberalization Since Independence ……......................................... 76

E. Preferential Trade Relations and WTO Accession ........................................ 82

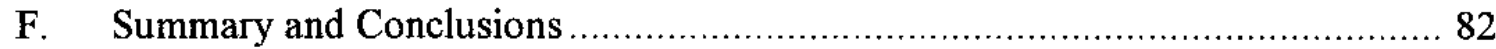

\section{Text Boxes}

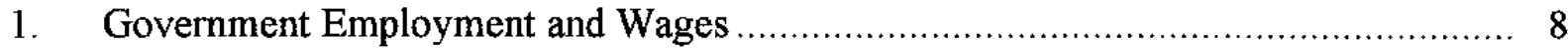

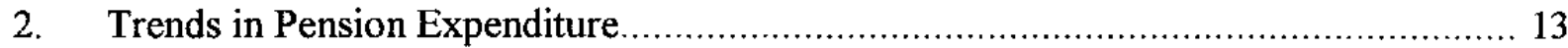

Figures

1. General Government Expenditure and Net Lending in Selected CEE and EU

Countries, 1994-98 ............................................................ 7

2. Consolidated Central Government Expenditure by Function, 1994-99 …................ 11

3. Structure of Public Sector Debt in September 1999 …........................................... 18

4. Number of Commercial Banks by Ownership, 1991-98 _......................................... 34

5. Assets and Liabilities of Top Five Banks by Assets, 1996-99 ................................. 41

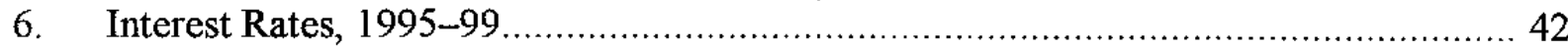

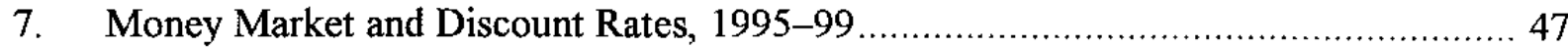

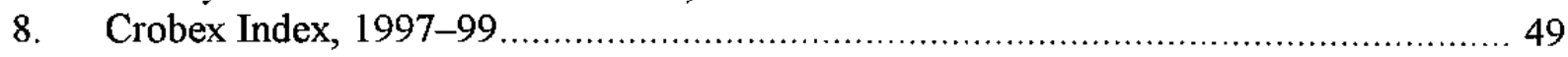

9. External Vulnerability Indicators in a Regional Perspective ................................... 59

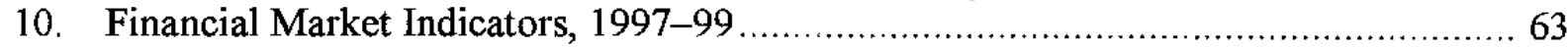

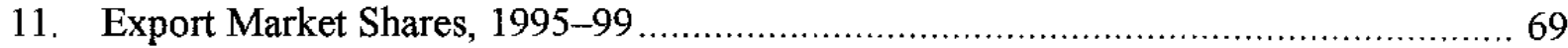

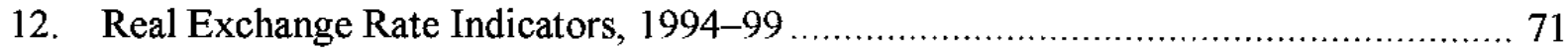

13. Unit Labor Costs of Croatia and Its Main Trading Partners, 1995-99 _.................... 72

14. Central and Eastern Europe: Real Exchange Rate Developments, 1994-99 ............... 74

Text Tables

1. General Government Balance and Expenditure and Net Lending in CEE

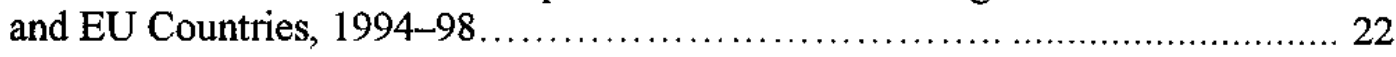

2. General Government Subsidies and Transfers, 1994-99 ….................................. 23

3. Consolidated Central Government Expenditure by Function, 1994-99 ….................. 24

4. Government Sector Social Spending in CEE Countries, 1997-98 …....................... 25

5. Number of Beneficiaries and Pension Payments by the Croatian

Pension Institute, 1993-2000 ................................................................. 26

6. Consolidated General Government Revenue and Expenditure by Level of

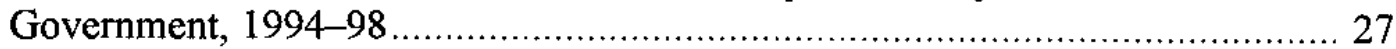

7. Comparison of General Government Revenues in Selected CEE Countries, 1998 ...... 28

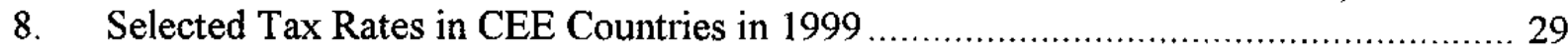

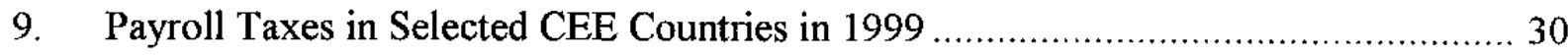

10. Total Debt of the Consolidated Central Government in Selected CEE

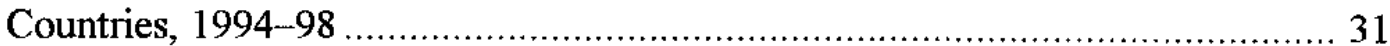

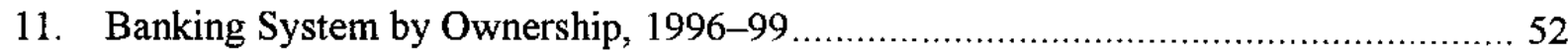

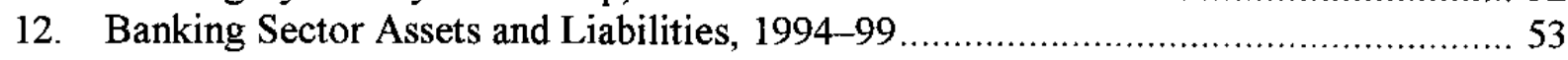

13. Quality of Banks' Loan Portfolio, 1994-98 …................................................ 54

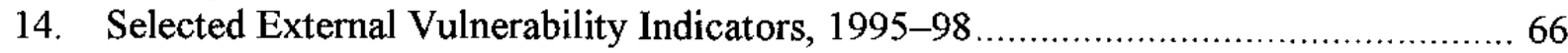

15. Central and Eastern European Countries: Export Performance Indicators .................. 85 
16. Central and Eastern Europe: Tariff Structure Summary and Trade

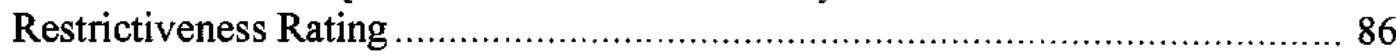

17. Central and Eastern Europe: Trade Arrangements, ...................................... 87

Appendices

I. Summary of the Croatian Exchange and Trade System .................................... 88

II. Summary of the Croatian Tax System .................................................... 92

Statistical Appendices

18. Quarterly GDP at Constant 1997 Prices, 1991-99 _......................................... 98

19. Gross Value Added and Gross Domestic Product at Current Prices, 1995-98 .......... 99

20. Gross Domestic Product at Constant Prices, 1996-98 ........................................ 100

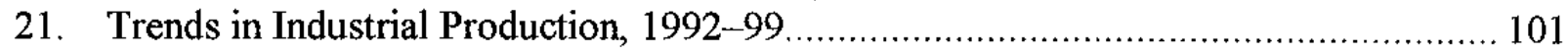

22. Agricultural Production, 1991-98 f........................................................ 102

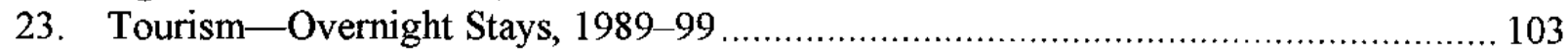

24. Nights Spent by Tourists According to Type of Accommodation, 1992-98............ 104

25. Nights Spent by Tourists According to Country of Origin, 1992-98_.................... 105

26. Composition of Employment, 1996-98 .................................................... 106

27. Trends in Employment and Unemployment, 1990-98 ...................................... 107

28. Trends in Total Labor Costs, 1998-99 ........................................................ 108

29. Trends in Average Monthly Net Wages and Salaries, 1994-99 ............................ 109

30. Average Gross Monthly Pay Per Employee, 1996-99 ....................................... 110

31. Indices of Nominal Net Wages and Salaries Per Employee, 1996-99 .................... 111

32. Indices of Real Net Wages and Salaries Per Employee, 1996-98 ........................ 112

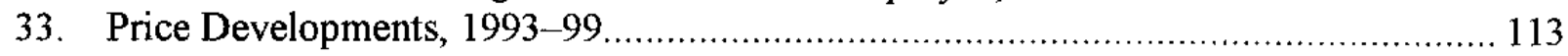

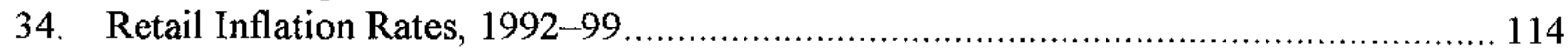

35. Employment in National Public Enterprises, 1992-98.................................... 115

36. Number of Enterprises in the Economic Sector and Number
of Legal Entities Undergoing Bankruptcy, 1993-98

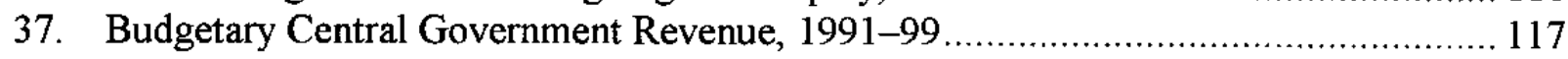

38. Budgetary Central Government Expenditure and Net Lending, 1992-99................ 118

39. Budgetary Central Government Expenditure by Function, 1991-99 ....................... 119

40. Consolidated Central Government Fiscal Accounts, 1991-99 ............................ 120

41. Outstanding Stocks of Domestic Debt of the Central Budgetary

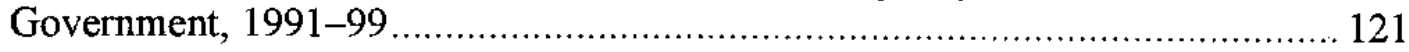

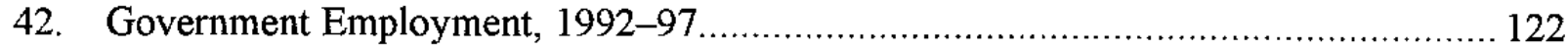

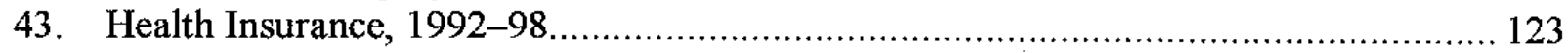

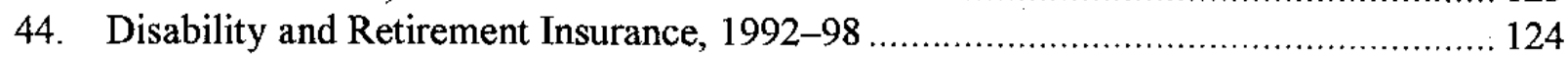

45. Accounts of the Health Fund, 1994-99 ....................................................... 125

46. Accounts of the Pension and Disability Insurance Fund, 1991-99 ......................... 126

47. Key Indicators of the Pension System, 1991-98............................................. 127

48. Consolidated General Government, 1994-98 …............................................ 128

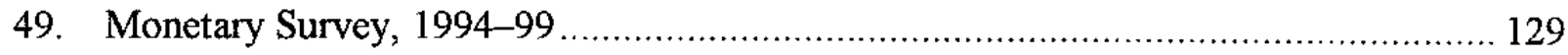

50. Monetary Authorities' Balance Sheet, 1994-99 ............................................. 130

51. Deposit Money Banks’ Accounts, 1994-99 .................................................. 131

52. Deposit Rates of the Croatian National Bank, 1994-99 .................................. 132 


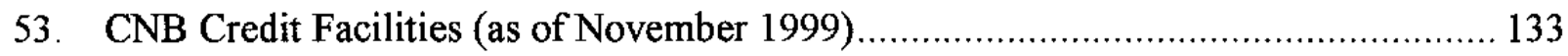

54. Credit Rates of the Croatian National Bank, 1994-99 ……................................. 134

55. Deposit Money Banks' Deposit Rates, 1994-99................................................ 135

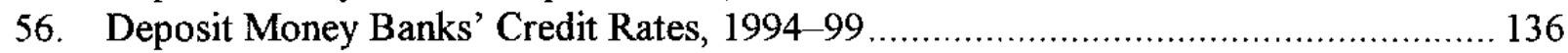

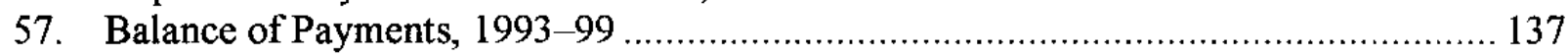

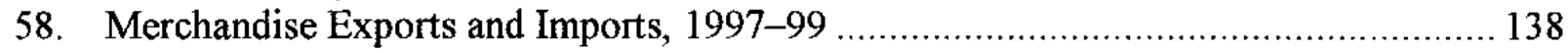

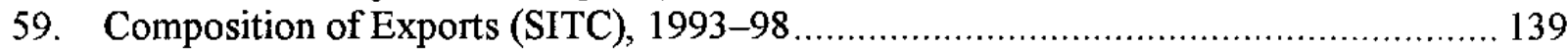

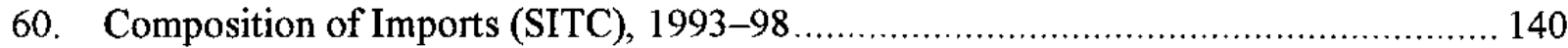

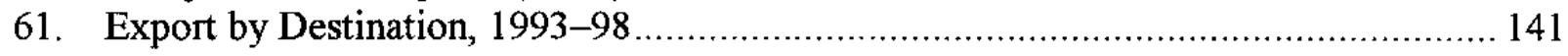

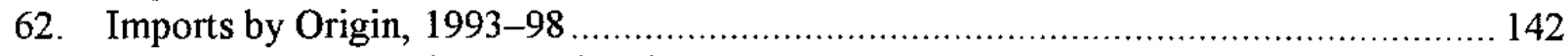

63. Exchange Rates and International Reserves, 1996-99 ...................................... 143

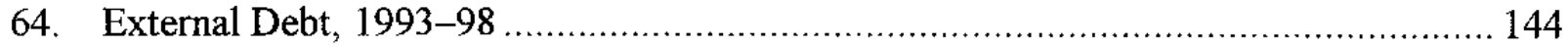


Croatia: Basic Economic Indicators, 1994-1999

\begin{tabular}{|c|c|c|c|c|c|c|}
\hline & 1994 & 1995 & 1996 & 1997 & 1998 & $\begin{array}{r}1999 \\
\text { Staff Proj. }\end{array}$ \\
\hline \multicolumn{7}{|l|}{ Real economy } \\
\hline Real GDP (percentage change) & 5.9 & 6.8 & 6.0 & 6.5 & 2.5 & -2.1 \\
\hline Unemployment rate (average; percent of labor force) $1 /$ & 14.5 & 14.5 & 16.4 & 17.5 & 17.2 & 20.14 \\
\hline Nominal gross wages (percentage change; period average) & $\quad \ldots$ & 34.0 & 12.3 & 13.1 & 12.6 & 10.45 \\
\hline Retail prices (percentage change; end of period) & -3.0 & 3.7 & 3.4 & 3.8 & 5.4 & 5.0 \\
\hline Gross national saving (percent of GDP) & 23.1 & 9.9 & 16.3 & 16.6 & 16.1 & 18.3 \\
\hline Gross domestic investment (percent of GDP) & 17.4 & 17.6 & 22.1 & 28.2 & 23.2 & 24.8 \\
\hline \multicolumn{7}{|l|}{ Public finance (percent of GDP) } \\
\hline Central budget (cash basis) & 0.6 & -0.7 & -0.1 & -0.9 & 0.9 & -0.1 \\
\hline Excluding privatization & 0.2 & -1.3 & -1.2 & -1.3 & -0.4 & -4.3 \\
\hline Consolidated central government (cash basis) $2 /$ & 1.6 & -0.9 & -0.4 & -1.3 & 0.6 & -0.7 \\
\hline Excluding privatization & 1.2 & -1.7 & -1.6 & -2.5 & -1.0 & 4.9 \\
\hline \multicolumn{7}{|l|}{ Money and credit (end of period; percentage change) } \\
\hline Broad money & 74.5 & 40.2 & 49.3 & 38.4 & 13.0 & -3.7 \\
\hline Credit to consolidated central government & -18.1 & -3.0 & -3.5 & -49.9 & -2.7 & 19.7 \\
\hline Other credit & 36.3 & 18.6 & 3.1 & 44.4 & 22.4 & -2.8 \\
\hline Average credit interest rate (end of period; percent) & 15.4 & 22.3 & 18.5 & 14.1 & 16.1 & $14.06 t$ \\
\hline \multicolumn{7}{|l|}{ Balance of payments } \\
\hline Trade balance (percent of GDP) & -8.0 & -17.4 & -18.6 & -26.0 & -19.1 & -17.6 \\
\hline Current account balance (percent of GDP) & 5.7 & -7.7 & -5.8 & -11.6 & -7.1 & -6.5 \\
\hline Total external debt (percent of GDP; end of period) & 22.5 & 20.8 & 23.2 & 31.9 & 37.1 & 39.0 \\
\hline Official reserves (US\$ million; end of period) & 1,405 & 1,895 & 2,314 & 2,539 & 2,816 & 2,783 \\
\hline Reserve cover (months of imports of goods and services) & 2.5 & 2.4 & 2.8 & 2.7 & 3.2 & 3.4 \\
\hline Short-term debt in percent of gross usable reserves $3 /$ & 35.2 & 31.6 & 40.7 & 45.6 & 51.4 & 88.1 \\
\hline \multicolumn{7}{|l|}{ Exchange rate } \\
\hline Nominal effective rate $(1995=100 ;$ end of periad $)$ & 96.8 & 99.1 & 101.0 & 102.8 & 98.0 & $99.86 /$ \\
\hline Real effective rate $(1995=100$; end of period $)$ & 97.6 & 98.6 & 99.8 & 101.6 & 100.0 & $102.76 /$ \\
\hline \multicolumn{7}{|l|}{ Gcographic, social, and demographic indicators } \\
\hline Per capita GDP (at market exchange rates) & & & & & $\$ 4,663$ & \\
\hline Land area $\left(\mathrm{km}^{2}\right)$ & & & & & 56,538 & \\
\hline Population & & & & & $4,501,000$ & \\
\hline Population density (people per $\mathrm{km}^{2}$ ) & & & & & 79.6 & \\
\hline Population growth (in percent) & & & & & -1.5 & \\
\hline Life expectancy at birth (years) & & & & 72 & & \\
\hline Male & & & & 68 & & \\
\hline Female & & & & 77 & & \\
\hline Infant mortality rate (per 1,000 live births) & & & & 8.2 & & \\
\hline Crude death rate (per 1,000 people) & & & & & 12.0 & \\
\hline
\end{tabular}

Sources: Croatian authorities; Information Notice System; and IMF staff estimates.

1/ Registered average unemployment rate. According to the Labor Force Survey (based on ILO standards), the unemployment rate was 10.0 percent in November 1996 and 12.6 percent in the first half of 1999.

$2 /$ Including extrabudgetary funds.

3/ On a remaining maturity basis; limited to debt contracts registered with the CNB.

4/ In October 1999.

5/In January-August 1999.

6/ In September 1999. 


\section{Trends in Croatia's Government Sector: A Cross-Country Perspective'}

\section{A. Size of the Government Sector}

1. Consolidated general government expenditure and net lending (ENL), on a cash basis, has risen steadily since the mid-1990s, to 52 percent of GDP in 1998, reflecting in part the cost of post-war reconstruction and compensation, and transition- and demography-induced changes in labor force participation. ${ }^{2}$ In periods of budgetary pressure, expenditures have also been financed by non-cash methods, including arrears accumulation and issuance of shares in state-owned companies. This would imply that cash-based measures tend to understate the true level of expenditures in such periods. ${ }^{3}$

2. Total revenue of the consolidated general government has tended to keep pace with expenditure and, on average, revenues provided full coverage of budgetary cash expenditures. ${ }^{4}$ Excluding the proceeds from privatization, however, the consolidated general government recorded an average cash deficit of more than 1 percent of GDP during 1994-98, while the primary balance (which excludes interest payments) averaged a surplus of 1.4 percent of GDP. This performance compares favorably with that in other Central and Eastern European (CEE) and EU countries (see Table 1).

3. In relation to GDP, Croatia's general government expenditure is large relative to EU and CEE countries. Moreover, one would expect that the fiscal sector would contract during the transition process as state subsidies to enterprises and consumers are reduced and the range of services provided by the state is scaled back. This tendency is evident in most other transition countries, but has not been observed in Croatia, where the state has increased its role in the economy in most functional and economic categories (see below and Figure 1).

\footnotetext{
${ }^{1}$ Prepared by Rachel van Elkan.

${ }^{2}$ The general government consists of the central government, five extrabudgetary funds (EBFs), and local governments (421 municipalities, 122 cities and 21 counties).

${ }^{3}$ When repayment of arrears is recorded above the line (as occurred in 1999), the use of arrears does not affect the overall level of cash spending, but postpones the recording of the expenditure.

${ }^{4}$ The cumulative deficits of between $1 / 2$ and $1 \frac{1}{4}$ percent of GDP recorded in 1995-97 were exactly offset by surpluses in 1994 and 1998.
} 
Figure 1. General Government Expenditure and Net Lending in Selected CEE and EU Countries, 1994-98 1/ (In percent of GDP)

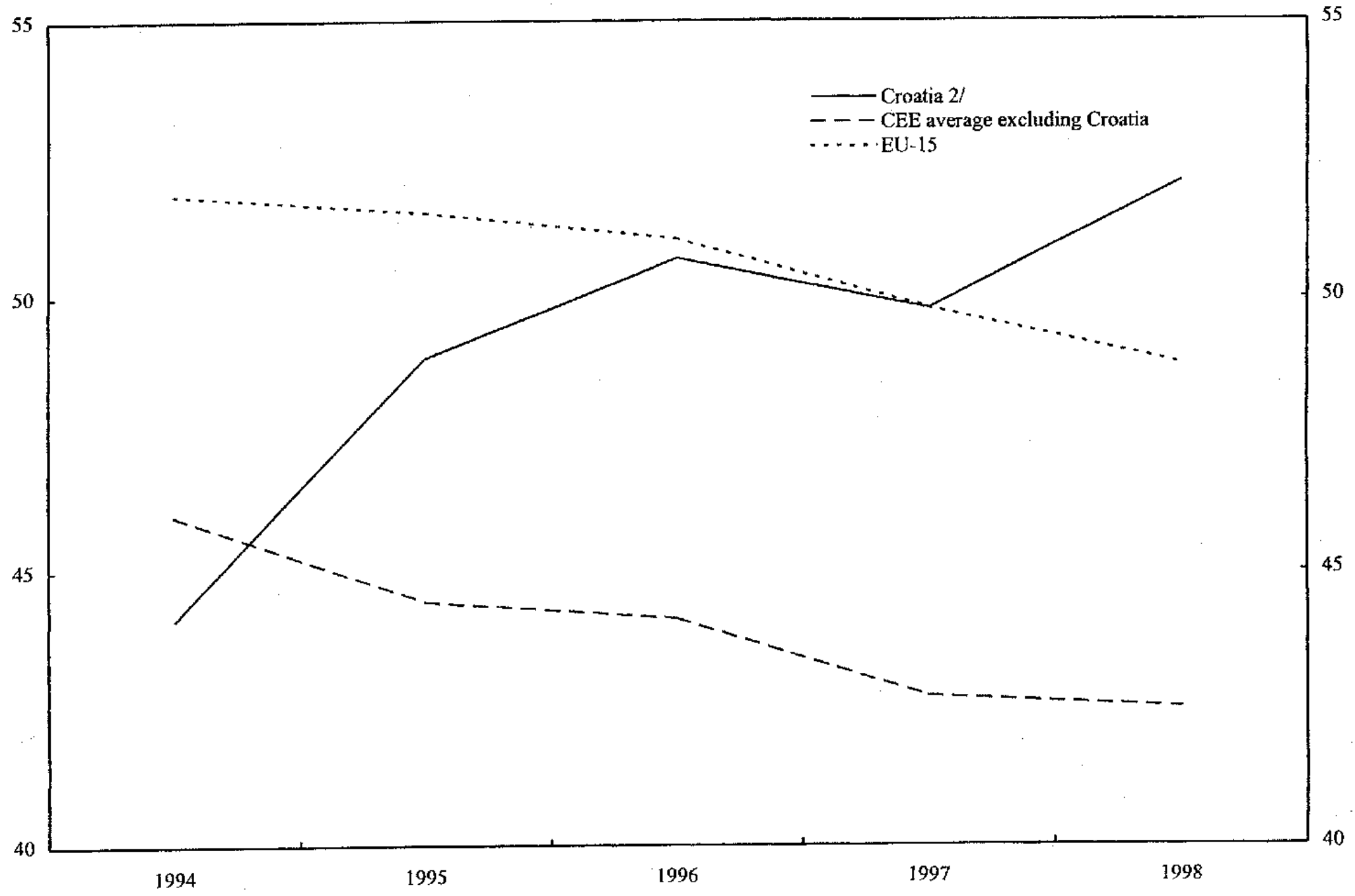

Source: WEO.

1/ Central and Eastern European countries include: Bulgaria, Czech Republic, Hungary, Poland, Romania, Slovakia, and Slovenia. 2/ Cash basis. 


\section{B. Composition of Expenditure}

\section{Economic classification}

4. The major expenditure items in the 1998 consolidated general government budget were transfers to households, nonprofit institutions and abroad (15.7 percent of GDP), goods and nonlabor services (12.7 percent of GDP), wages and salaries (11.8 percent of GDP), and capital expenditure (6.9 percent of GDP). These categories were also the four largest in 1994, but were ranked as follows: goods and nonlabor services (15.6 percent of GDP), transfers (11.2 percent of GDP), wages and salaries (10.4 percent of GDP), and capital expenditure (3.1 percent of GDP). Reflecting the relatively low level of public sector debt (see below), interest payments accounted for only about 1.5 percent of GDP on average since 1994. Moreover, a shift from domestic debt to cheaper external borrowing helped to further contain interest costs during the period.

\section{Box 1. Government Employment and Wages}

During 1994-98, the total wage bill of the general government increased by 80 percent, while employment (excluding the police and army) is estimated to have declined by $3 \frac{1}{2}$ percent. ${ }^{1}$ Moreover, while no data is available for previous years, it is thought that employment in the ministry of defense and the police was substantially higher than the 72,600 reported in 1998. This implies that average public sector wages rose by at least 84 percent during 1994-98. Despite the decline in the level of government sector employment (excluding the police and army), its share of total employment has risen slightly from 20 percent in 1994 to $211 \frac{1}{2}$ percent in 1998 , reflecting the larger decline in economy-wide employment during the period. Including security forces, the general government accounted for 26 percent of total employment in 1998.

Public administration at the central government, EBFs and local governments accounted for 16 percent of total government employment in 1998, while the police and armed forces, health and social services, and education each accounted for just over a quarter of total government employment. Gross earnings in public administration were 22 percent higher than the national average in 1998, while in health and education they were 20 percent above and 2 percent below the national average, respectively. ${ }^{2}$

\footnotetext{
${ }^{1 /}$ Public sector employment is defined as the sum of employment in public administration, compulsory social security, education, health and social work, and sanitation.

${ }^{2 /}$ Large wage increases granted in 1999 have raised wages in public administration and health care further above the national average. Following the 12 percent increase granted in December 1999, wages in public administration are expected to exceed even those in the financial services sector (which previously had the highest level of gross wages) by nearly 7 percent.
}

5. An indication of the redistributive nature of budgetary spending is given by the sum of subsidies and current and capital transfers (which is defined as all unrequited government 
cash payments). This item increased from 13.8 percent of GDP in 1994 to 20.8 percent of GDP in 1998, when it accounted for nearly two-fifths of total general government ENL (see Table 2). ${ }^{5}$ Spending in this category includes support to industry, various segments of the domestic population, and foreign governments and residents. Support to public and private enterprises through these channels in 1998 was 2.8 percent of GDP, up from 2.2 percent of GDP in $1996 .{ }^{6}$ The main beneficiaries during 1994-98 were the publicly owned Croatian Railways (averaging 1.2 percent of GDP), the agricultural sector (averaging 0.6 percent of GDP), the maritime industry (averaging 0.2 percent of GDP) and, more recently, the tourism sector. Subsidies and transfers to support the restructuring and rehabilitation of enterprises adversely affected by the transition process and the war amounted to 0.5 percent of GDP in 1997 and 1998.

6. Post-war related spending accounts for a large part of total subsidies and transfers and encompasses reconstruction of housing and infrastructure (averaging 1.1 percent of GDP during 1995-98), and transfers to veterans, invalids and civil war victims (averaging 1.5 percent of GDP during 1995-98). ${ }^{7}$ However, this understates the full extent of unrequited cash spending for post-war related purposes since transfers to veterans from the pension fund were not separately identified during 1994-96. Post-war related transfers are budgeted to increase to 3.1 percent of GDP in 1999.

7. The Croatian budget also provides financial support to the government and residents of Bosnia and Herzegovina, primarily to finance pensions of war veterans and to underwrite the Croat component of the Federation army. The amount of this support in 1999 is budgeted at 0.4 percent of GDP. Other types of transfers and subsidies include pensions, sick pay and maternity pay (see below), as well as consumer subsidies.

\section{Functional classification}

8. A functional classification is prepared by the Ministry of Finance only for unconsolidated central government expenditure. An estimate of consolidated central government expenditure (including the extrabudgetary funds, but excluding local

\footnotetext{
${ }^{5}$ Moreover, this item is budgeted to increase further in 1999 to 23.3 percent of GDP. All references to the 1999 budget refer to the revised budget.

${ }^{6}$ Additional budgetary support to industry is provided through the payment of interest and principal on guaranteed loans and, in 1999, through the cancellation of debt (primarily of the shipyards) to the pension and health funds for unpaid contributions. In the first nine months of 1999 , payments on guaranteed loans financed from the current budget were nearly HrK 470 million ( 0.3 percent of GDP), but total payments for this purpose-which are financed from past budgetary contributions to the guarantee reserve fund - are thought to have been significantly greater.

${ }^{7}$ This category excludes in-kind benefits (including to refugees) and capital goods acquired for reconstruction purposes.
} 
governments) by function was prepared by IMF staff by netting out intragovernmental transactions and allocating expenditures of the EBFs to various functional categories on the basis of available information regarding the purpose of the spending. ${ }^{8}$ The resulting functional breakdown of expenditures is shown in Table 3 and Figure 2.

9. The largest components of consolidated central government expenditure in 1998 were social security and welfare (16.3 percent of GDP), health (6.5 percent of GDP), defense (4.5 percent of GDP), and education (3.0 percent of GDP). This compares with the following structure of spending in 1994: social security and welfare (12.2 percent of GDP), defense (8.0 percent of GDP), health (5.6 percent of GDP), and education and public order and safety (each 2.9 percent of GDP). Total spending for social purposes (defined as social security and welfare, health and education) increased from 51.1 percent of total consolidated central government expenditure (20.6 percent of GDP) in 1994 to 56.4 percent of total spending (25.7 percent of GDP) in 1998. A further increase of $2 \frac{1}{2}$ percentage points of GDP is budgeted for 1999 .

10. Among the expenditure functions, the largest increases during 1994-98 were recorded in social security and welfare (4.1 percentage points of GDP) and housing and community amenities ( 1.7 percentage points of GDP), while the largest decline (3.4 percentage points of GDP) occurred in defense spending. These shifts reflect the improved security situation during the period that permitted a redistribution of expenditure from defense purposes to social outlays arising from post-war related priorities (including housing for veterans) and demographic shifts in the population. Significant increases are budgeted for 1999 in the categories "mining, manufacturing, construction" reflecting an increase in budgetary assistance to public and private enterprises, ${ }^{10}$ in "transport and communications" due to the initiation of an extensive road construction program, and in "expenditures not classified" reflecting the payout of insured deposits in failed banks financed from the budget and part of the transfer to Bosnia-Herzegovina.

${ }^{8}$ For example, sickness and maternity benefits paid by the health fund are recorded as social welfare spending, rather than health spending.

${ }^{9}$ This approach excludes net lending and local government expenditure, which together amount to about 5 percent of GDP.

${ }^{10}$ The revised 1999 central budget includes capital transfers to the pension and health funds in exchange for shares acquired by the funds through debt-equity swaps with the shipyards. In its functional classification, the Ministry of Finance (MoF) includes these capital transfers as manufacturing expenditure (which would be consistent with the central budget transferring the funds directly to the shipyards which, in turn, would then pay their obligations to the EBFs). However, in its calculation of total consolidated central government expenditure, the MoF treats these capital transfers as an intragovernmental transaction, implying that total consolidated expenditure would be lower than if the government transferred the funds directly to the shipyards. 
Figure 2. Croatia: Consolidated Central Government Expenditure by Function, 1994-99

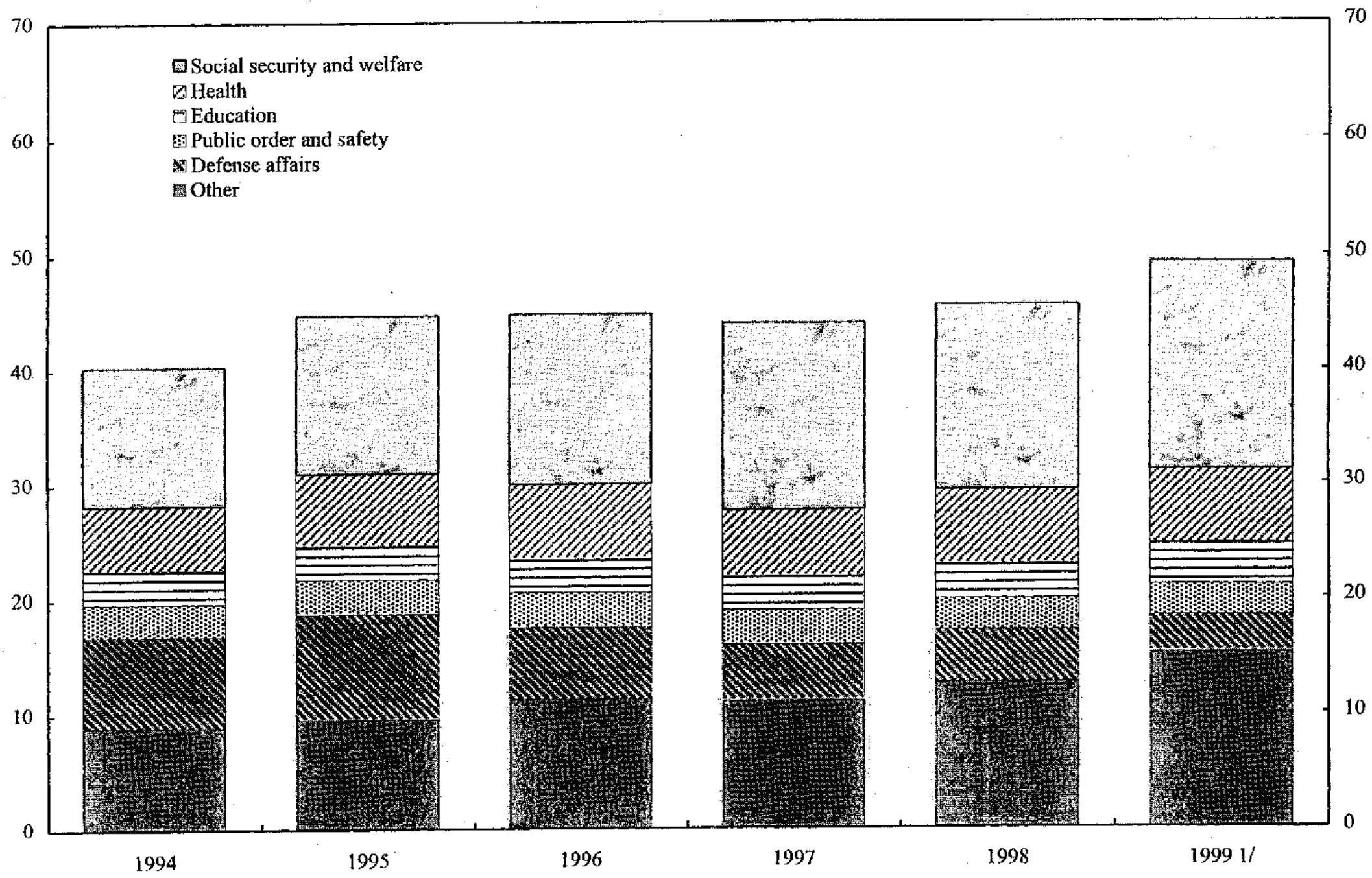

1
5
1

Sources: Ministry of Finance and IMF staff estimates.

1/ Revised budget 
11. The majority of spending for social security and welfare is devoted to retirement, invalidity, widows' and veterans' pensions, sickness and maternity benefits, unemployment benefits, and child benefits. ${ }^{11}$ With the exception of sick pay, which has risen sharply reflecting the liberal use of these benefits as an alternative form of unemployment relief, spending on benefits has remained stable since 1994 at around $23 / 4$ percent of GDP. In contrast, expenditure for pensions rose by more than 4 percentage points of GDP between 1994-98, to nearly 12 percent of GDP, and is budgeted to increase further in 1999 to nearly 14 percent of GDP.

12. Government social spending is relatively high by international standards (see Table 4). Spending on health, education, and social security and welfare by the consolidated central government in 1998 was equal to 25.7 percent of GDP in Croatia, compared with an average of 23.4 percent of GDP in CEE countries. ${ }^{12}$ This reflects spending on social security and welfare and health that was 2 percentage points of GDP and 1.5 percentage points of GDP, respectively, above the regional average, whereas education spending was 1.2 percentage points of GDP below the regional average.

13. However, in order to assess whether Croatia's social spending is out of line with that of other countries, adjustment should be made for the additional burden imposed on social spending by post-war obligations. Non-war related social expenditure (proxied by total social spending excluding expenses for refugees and others affected by civil war, and pensions for veterans, survivors and the disabled) totaled 19.5 percent of GDP in 1998, which is well below the regional average. However, non-war related social spending is budgeted to increase rapidly in 1999 to 23.1 percent of GDP, close to average social spending in CEE countries. $^{13}$

\section{Expenditure for specific purposes}

14. A functional classification based on the GFS methodology provides a sectoral breakdown of government expenditure. However, the classifications used by the authorities is quite broad, while expenditures which benefit some groups fall under different functional categories, making it difficult to identify total benefits for specific purposes. In this section, an attempt is made to identify and consolidate total budgetary resources devoted to three key policy priorities: post-war related purposes; road infrastructure and maintenance; and bank rehabilitation.

${ }^{11}$ Also included in this category are the costs associated with administering the welfare system and transfers in kind, including to veterans.

${ }^{12}$ The figures for Bulgaria, Hungary, Romania, and Slovakia relate to general government expenditure. To the extent that local governments undertake social spending, the comparable figures would be larger in Croatia, the Czech Republic, and Poland.

${ }^{13}$ However, 1.2 percentage points of this increase reflects temporary factors associated with the retroactive indexation of pensions. 


\section{Box 2. Trends in Pension Expenditure}

The expansion in pension expenditures since 1994 largely reflects population aging, the increase in the minimum guaranteed pension in 1996, legislated and constitutional court mandated retroactive indexation of pensions to wages, 'and the granting of pensions to war veterans and invalids, as well as to families of war victims. In addition, reintegration into Croatia of Eastern Slavonia and other regions in 1997 substantially increased pension obligations by increasing the number of beneficiaries. ${ }^{2}$

Between 1993 and 1999, the total number of pension beneficiaries grew by more than 26 percent, to just under one million (21.7 percent of the population). Since 1993, the number of old-age, disability, and survivors' pensioners increased by 23 percent, 27 percent, and 7 percent, respectively (Table 5). However, since veterans receiving pensions were recorded until 1999 according to the type of pension they received, the change in the number of recipients of old-age, disability, and survivors benefits in 1999 understates the actual increase in the number of non-veteran beneficiaries. ${ }^{3}$ More than half of all beneficiaries were old-age pensioners in 1999 , while disability and survivors pensioners each accounted for more than a fifth of all pensioners.

The rapid increase in the number of pensioners generated a sharp rise in the dependency ratio (defined as the ratio of pension beneficiaries to total employment) from 63 percent in 1993 to 96 percent in 1999. Also contributing to the increase in the dependency ratio-and to the financial burden on the current PAYG pension system - was a rapid decline in the number of contributors to the pension fund, reflecting lower overall employment and a shift of workers from an employment to a contractual relationship in order to avoid social security contributions.

Croatia: Dependency Ratio

(Period average)

\begin{tabular}{lllllll}
1993 & 1994 & 1995 & 1996 & 1997 & 1998 & $\begin{array}{l}1999 \\
\text { Jan.-Aug. }\end{array}$ \\
\hline
\end{tabular}

Ratio of pension beneficiaries

to total employment

63.4

67.2

81.6

83.4

91.2

87.6

96.0

Despite a fourfold increase in average pension benefits, replacement rates fell sharpiy between 1993 and 1999 , from 58 percent to 41 percent, as pension levels failed to keep pace with the growth in net wages. The oid-age replacement rate (defined as the ratio of the average old-age pension to the average net wage) declined even faster during this period, from 67 percent to 43 percent, reflecting the compression of benefits across different pension types, as the old-age benefit slipped from 1.45 to 1.15 times the pension with the lowest average benefit level (which was the survivors benefit in most years). This narrowing of old-age disability and survivors' benefits was fully reversed in 1999 , owing to the separate identification of benefits paid by the pension fund to veterans and members of the Croatian army, which were more than 175 percent of the average net wage and nearly six times the average old-age benefit level in 1999. In addition, veterans receive transfers from the central budget amounting to 0.6 percent of GDP.

\footnotetext{
'As part of the stabilization program of October 1993, the automatic indexation of pensions to wages was suspended through annual decree, and enshrined in law in February 1997, when the principle of price indexation of pensions was adopted. A 1998 ruling judged as unconstitutional the suspension of wage indexation of pensions and, in order to partially redress the fall in the replacement rate, the government decided to pay out an additional HrK 7.5 billion ( $51 / 4$ percent of 1999 GDP) in pensions during 1998-2001. Of this total, HrK 590 million was paid in 1998, and HrK 1.75 billion is to be paid in 1999.

${ }^{2}$ Reintegration also added to the deficit of the pension system since the increase in benefit payments was not matched by contribution receipts from the war-affected areas.

${ }^{3}$ The number of old-age pensioners increased by 10 percent in 1999 , as many workers opted for early retirement in order to receive benefits they were entitled to under the pre-reform pension system. However, official data indicate a smailer increase in the number of old-age pensioners, once veterans receiving old age pensions are separately identified. The jump in the total number of pensioners accounts for a significant part of the increase in pension expenditure projected for 1999.

${ }^{4}$ Since a proportionately larger number of veterans are eligible for disability and swyivors benefits, the average level of these benefits dropped sharply in 1999 once veterans were removed from those groups of beneficiaries.
} 


\section{Post-War Expenditure}

15. Post-war spending encompasses expenditure for reconstruction (primarily housing), and cash and in-kind benefits in support of veterans, invalids, refugees and others affected by civil war. Between 1995 and 1999, identifiable post-war budget expenditure totaled Hrk 21.7 billion (15.3 percent of 1999 GDP). Aid to veterans and invalids accounted for more than half of budgetary post-war spending, while reconstruction and refugees accounted for 30 percent and 17 percent, respectively. Reflecting their subsequent resettlement, spending for refugees declined over time, whereas spending in support of veterans and invalids increased more than three-fold between 1995 and 1999.

\section{Road construction and maintenance}

16. In support of the authorities' policy to improve cross-border and internal transport links, government expenditure for the construction and maintenance of roads accounted for 4.1 percent of 1999 GDP on a cumulative basis between 1996 and 1999, much of it financed by earmarked foreign loans. In addition, the government provided guarantees on foreign loans to private road construction companies in the amount of HrK 1,960 million (US $\$ 260$ million or 1.4 percent of GDP), and has granted VAT-exempt status to one such company, thereby raising the fiscal cost of road construction through foregone tax revenues.

\section{Banking sector rehabilitation}

17. The fiscal cost of bank rehabilitation is the sum of cash payments to troubled banks and the bank rehabilitation agency (to finance payouts of insured deposits in failed banks), and newly issued public sector debt to recapitalize banks that entered the rehabilitation program. ${ }^{14}$ During 1996-99, total cash injections amounted to HrK 2.6 billion (1.8 percent of 1999 GDP), while debt issues totaled HrK 5.3 billion (3.7 percent of 1999 GDP).

\section{The Structure of General Government}

18. The general government is divided into three parts: the central government; the extrabudgetary funds; and the local governments. The first two parts combine to form the consolidated central government. There are currently five extrabudgetary funds (pension,

${ }^{14}$ Since the Croatian National Bank (CNB) is not permitted to carry over any government debt from one calendar year to the next, an additional fiscal cost associated with the banking sector arises from the need to repay ahead of schedule government debt used by failed banks as collateral to secure liquidity loans from the CNB. The amount of early repayment in 1999 is about $\mathrm{HrK} 130$ million ( 0.1 percent of GDP). 
health, employment, child, and water).$^{15}$ The local government level is further divided into counties, cities, and municipalities, of which there are several hundred (see footnote 1).

19. A complex system of grants, revenue-sharing arrangements, and social security contributions connects the different levels of government, while smaller transfers also link branches within the same level of government. Transfers from the central budget to other parts of government-which are the largest type of intragovernmental transfer - totaled HrK 6.5 billion (4.7 percent of GDP) in 1998, compared with HrK 2.0 billion (2.0 percent of GDP) in 1994. Of these, HrK 220 million and HrK 6.2 billion went to the EBFs in 1994 and 1998 , respectively. Transfers from the central budget to other parts of government are budgeted to rise further to $\mathrm{HrK} 11.1$ billion (7.8 percent of GDP) in 1999, of which HrK 10.5 billion is slated for the EBFs.

20. These transfers distort the magnitude of underlying revenues and expenditures recorded by the donor and the recipient. Based on consolidated data (i.e., excluding intragovernmental transactions), the central budget and the EBFs accounted for 47 percent and 42 percent, respectively, of general government expenditure in 1998 (see Table 6). The share of the central government in total expenditure (and in GDP) declined sharply since 1994 , due to spending increases by the pension and health funds, and the local governments. $^{16}$

21. As a share of consolidated revenue, in 1998 the central government collected 60 percent of the total, while the EBFs collected 29 percent. The larger revenue-earning capacity of the central government reflects its ability to levy taxes on goods and services and income, as well as privatization receipts. The EBFs' main revenue source is wage-based contributions, while the local governments rely mainly on surcharges on income taxes collected by the central budget. ${ }^{17}$

${ }^{15}$ The road fund was absorbed into the central budget in 1995. The general government does not include the Croatian Privatization Fund or the Croatian Bank for Reconstruction and Development (HBOR).

16 This decline is measured after correcting for the absorption of the Croatian Road Fund into the central budget in 1995 .

${ }^{17}$ Cities with populations in excess of 40,000 may impose a surcharge on the personal income tax collected by the central government. In the case of Zagreb, the permitted rate is up to 60 percent, while in other cities the ceiling is 30 percent. In addition, income taxes collected from individuals living outside Zagreb are shared between the state budget (70 percent), counties ( 5 percent), and cities ( 25 percent). In the case of income taxes collected from individuals living in Zagreb, 55 percent goes to the central budget and 45 percent is allocated to the city. A summary of the Croatian tax system is given in Appendix II of this report. 
22. Excluding intragovernmental transactions, the central government budget has consistently run a surplus, which rose to a level of 7.4 percent of GDP in 1998 and is expected to increase further in 1999. This has been offset by persistent deficits in the extrabudgetary funds (primarily the pension and health funds), which also reached a new high in 1998 at 6.5 percent of GDP. The consolidated net position of the local governments has remained near balance during 1994-98.

\section{Comparative Tax Rates}

23. Compared with other transition countries, Croatia's tax system imposes a heavy burden on the economy. Tax collections by the general government totaled 46.6 percent of GDP in 1998, 10 percentage points above the average of other CEE countries (Table 7). This was due primarily to VAT revenues, which were 6 percentage points of GDP above the average collected in other CEE countries, and to social security contributions, which were 1.7 percentage points higher than the cross-country average.

24. The strong revenue-generating capacity of Croatia's VAT reflects its relatively high rate and limited exemptions (Table 8) ${ }^{18}$ Apart from Bulgaria, Croatia is the only CEE country with a uniform rate and, at 22 percent, its level is also comparatively high. Croatia's large share of VAT revenues may also reflect significant underreporting of GDP in official statistics. Replacement of the sales tax with the VAT in 1998 boosted Croatia's indirect tax revenue by 3.8 percentage points of GDP compared to 1997 . However, a contraction in private consumption, together with reduced compliance, is expected to reduce sharply the revenue yield from the VAT in 1999. On the other hand, Croatia's direct tax rates are not substantially out of line with those in other CEE countries, and this is reflected in personal and corporate income tax collections that are close to the CEE average. ${ }^{19}$ Moreover, Croatia's personal and corporate income tax systems appear to be simpler than in most other transition countries, having fewer tax brackets and a limited number of exemptions.

Nonetheless, after raising the rate from 25 percent to 35 percent in 1997, Croatia's corporate tax rate is almost double that in Hungary, which cut its tax rate in a revenue-neutral manner by eliminating a wide variety of exemptions. However, owing to the exclusion of dividends and the "normal" return on equity from the taxable base and reduced rates in the war-affected areas, the effective corporate tax rate was 22.8 percent in 1998 . Unlike most other CEE countries, Croatia does not yet offer investment incentives in the form of corporate tax holidays, but the Ministry of Economy is working on a proposal to do so in the near future.

25. Croatia's payroll taxes to finance social security and other benefits are not out of line with other CEE countries (Table 9). Contributions are levied at a rate of nearly 42 percent of gross wages and, consistent with trends in several neighboring countries, this rate has

18 The zero rating for bread, milk, books, and prescription drugs was introduced only in November 1999.

19 This excludes, however, surtaxes of up to 60 percent levied by local governments on personal income taxes collected by the central government. 
declined somewhat in recent years in order to stimulate employment and reduce incentives for evasion. ${ }^{20}$ Nonetheless, sharply lower collections in 1999 are due in large part to a drop in payroll tax compliance.

\section{E. Public Sector Debt}

26. Debt of the central government (excluding domestic arrears) stood at HrK 42.1 billion (30.5 percent of GDP) in September 1999, of which two-thirds was external debt (Figure 3). ${ }^{21} 22$ This represents a 6 percentage point increase over the level at end-1998, owing to new foreign borrowing and the depreciation of the kuna during 1999, which increased the kuna equivalent of both external and domestic debt since the latter is mostly denominated in, or indexed to, foreign exchange.

27. Croatia's public sector debt is the result of several factors: the assumption of debt as part of the succession process since independence; the transition process; and multilateral lending.

- $\quad$ As a result of succession to the Socialist Federal Republic of Yugoslavia (SFRY), Croatia inherited in 1995 a part of the debt owed by the SFRY to creditor governments and banks under the terms of Paris and London club agreements. Of this debt, part was assumed by the enterprises and banks that received the original loan proceeds, while the remaining, unallocated portion was assumed by the Republic of Croatia. The government's London and Paris club debt accounted for 31 percent of total public debt in September 1999. ${ }^{23}$

- Succession to the SFRY was also responsible for the buildup of debt arising from the confiscation by the National Bank of Yugoslavia of banks' foreign exchange reserves. These reserves, which amounted to about US\$3 billion, were the counterpart assets to the private sector's foreign currency deposits. In 1991, the Republic of Croatia assumed responsibility for these claims against the former SFRY; however, since the

${ }^{20}$ Since mid-1998, the child benefit fund has been financed by the central budget, permitting a reduction in payroll contributions.

${ }^{21}$ Debt data for the general government is not available, but borrowing opportunities for the EBFs and the local governments (except for the city of Zagreb) are small and limited primarily to domestic bank credit.

${ }^{22}$ Domestic arrears of the consolidated central government are not included in official debt statistics, and the Ministry of Finance does not have accurate information on their level. Staff estimates that at end-1999, the stock of domestic arrears was equal to some 6 percent of 1999 GDP.

${ }^{23}$ The government also inherited some multilateral debt, primarily from the IBRD, amounting to nearly US\$130 million. 
Figure 3. Croatia: Structure of Public Sector Debt in September 1999 (In percent of total; total debt: Hrk 42.1 billion)

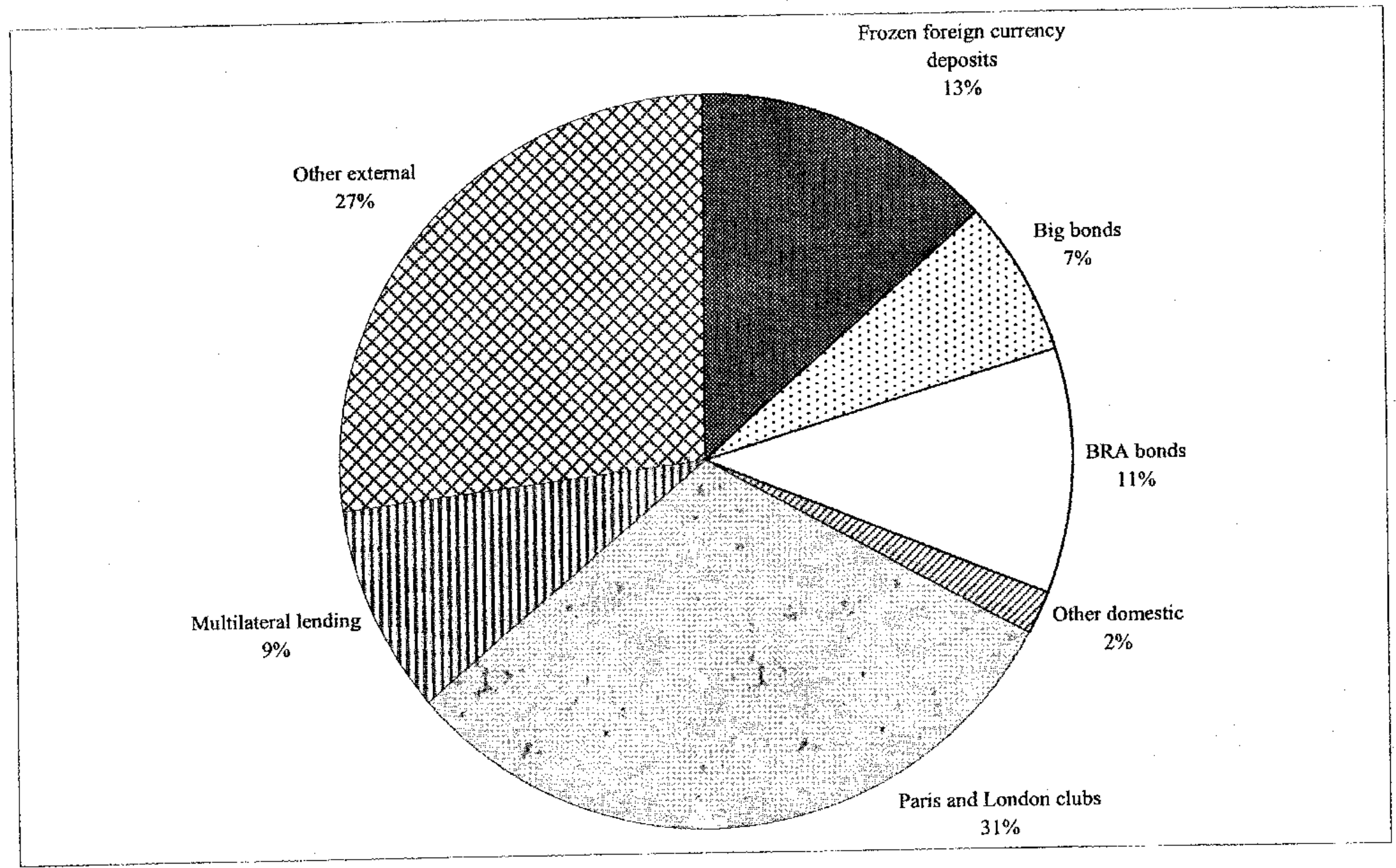


fledgling state had little foreign exchange reserves, the government issued to the commercial banks deutsche mark denominated "counterpart" bonds. ${ }^{24}$ The government also issued bonds (called JDA and JDB bonds) to finance the first two installments of principal of the counterpart bonds. Public debt associated with the frozen foreign exchange deposits accounted for 13 percent of total public debt in September 1999.

Reconstruction bonds, which were almost fully amortized by September 1999, were issued during 1992 and 1993 in an amount of about US\$80 million to finance the reconstruction of war-damaged property.

- $\quad$ Bonds to finance the rehabilitation and restructuring of enterprises (called "big bonds") were issued in 1991 in an amount of DM 1,550 million. They were used by the enterprises to clear their obligations to domestic banks. Outstanding public debt from this source stood at 7 percent of total public debt in September 1999.

- Official multilateral lending (primarily from the IBRD), to finance structural adjustment and sectoral projects, accounts for about 9 percent of the September 1999 public debt stock.

- $\quad$ The rehabilitation of five state-owned and renationalized banks during 1996-99 was associated with an increase in public debt (called bank rehabilitation agency (BRA) bonds) to recapitalize the banks and provide needed liquidity. Debt from this source accounted for 11 percent of public debt in September 1999, but the rehabilitation of an additional bank in October 1999 added a further $\mathrm{HrK} 550$ million to the stock of outstanding BRA bonds.

- The remaining 29 percent of public debt, which is largely foreign debt, has been used to refinance more expensive domestic debt.

28. Despite the recent increases, public sector debt has declined slightly from US\$5.9 billion in 1991 to US\$5.8 billion in September 1999 and remains relatively low in comparison to other transition countries, ${ }^{25}$ even though-unlike some other transition countries - Croatia has not seen the real value of its obligations eroded by rapid inflation (Table 10). The relatively low level of Croatia's public debt reflects moderate fiscal cash

\footnotetext{
${ }^{24}$ In order to prevent the withdrawal of these deposits from the domestic banking systemwhich would have precipitated the failure of the banks - these deposits were blocked for a period of three years (until July 1995), and thereafter unblocked at the minimum rate of 20 equal semi-annual installments.

${ }^{25}$ Data on public sector debt excludes the stock of arrears of the central government and the extrabudgetary funds.
} 
deficits, ${ }^{26}$ and the redemption of a significant part of domestic debt in exchange for stateowned assets, including housing and enterprise shares. ${ }^{27}$

29. While the level of debt contracted by the government remains moderate, public guarantees provided to loans from domestic and foreign sources have grown rapidly. Total outstanding public guarantees increased by HrK 4.6 billion from end-1998 to August 1999 to reach HrK 20.9 billion (14.7 percent of GDP). About 37 percent of guarantees are performance related, covering, inter alia, the on-time delivery of ordered goods, mostly ships.

30. External guarantees accounted for 47 percent of total outstanding guarantees in August 1999, and were equivalent to US\$1.4 billion or 6.9 percent of GDP. Major beneficiaries of external guarantees are Croatian Airlines, road construction companies, the shipbuilding industry, the state-owned Croatian Bank for Reconstruction and Development (HBOR), and Croatian Railways. External guarantees increased by HrK 3.5 billion (US $\$ 475$ million) during the first eight months of 1999, primarily in support of road construction and shipyards.

31. Regarding domestic guarantees, a large share is associated with lending by HBOR in support of various sectors of the economy, including shipbuilding, small enterprises, and tourism, as well as reconstruction of war-damaged industry and infrastructure. This lending is financed by government-guaranteed foreign borrowing, grants from the central budget and, until mid-1997, earmarked privatization receipts. To the extent that onlending by HBOR is financed by publicly guaranteed foreign borrowing, the state guarantees both the source and the use of the loan funds. Other publicly guaranteed domestic lending is undertaken by commercial banks and primarily supports public enterprises and tourism facilities.

\section{F. Conclusions}

32. Croatia's fiscal position appears relatively sound when measured by the overall balance and the public debt ratio. However, when compared with other CEEs and what would be expected during the transition process, Croatia's experience appears less favorable. In particular, the increase in the size of the government sector since the mid-1990s to more than 52 percent of GDP in 1998 reflects structural pressures on spending-including a rapidly increasing dependency ratio and an overly generous health and social transfer system-as well as excessive public sector wages and heavy spending in a number of areas.

33. A number of temporary budgetary obligations - including the cost of bank resolution and court-mandated supplementary pension payments - is expected to further increase general government expenditure in 1999 and 2000. Privatization receipts from state-owned utilities and banks will provide one-off coverage for these, while presenting a short window

${ }^{26}$ The cash deficits remained moderate, in part, because of the sale of state-owned assets.

${ }^{27}$ Public debt will increase by DM 120 million ( 0.3 percent of GDP) in early 2000 reflecting a bond issue to individuals whose property was confiscated during the previous regime. 
of opportunity in which to address the underlying structural deficiencies in the fiscal sector. However, the bulk of the privatization receipts is likely to be exhausted by 2002 , by which time the temporary budget obligations will also have been completed. Nonetheless, the structural problems will persist unless decisive measures are implemented early on. Resolving these problems will be complicated by the absence of an adequate public sector expenditure oversight and control mechanism. Moreover, the recent rapid increase in contingent government liabilities could lead to a substantial additional fiscal burden in light of the weak economic performance of several of the industries that received government guarantees.

34. Expenditure cuts will also be needed in response to the recent erosion in tax compliance, which experience from other countries suggests will be very difficult to reverse. Moreover, tax rates in several areas remain high in comparison to neighboring countries. In order to support increased compliance while improving external competitiveness and increasing Croatia's attractiveness to foreign investors, taxes on employment and profit should be reduced. However, given the uncertainties involved in projecting the likely savings from structural expenditure reforms, it is advisable that tax cuts be introduced only once expenditure savings have been realized. In addition, given the potentially significant revenue losses that could result from the planned introduction of corporate tax holidays, Croatia is advised to limit the breadth and duration of these incentives. 
Table 1. General Government Balance and Expenditure and Net Lending in CEE and EU Countries, 1994-98

(in percent of GDP)

\begin{tabular}{|c|c|c|c|c|c|}
\hline & 1994 & 1995 & 1996 & 1997 & 1998 \\
\hline \multicolumn{6}{|c|}{ Balance including privatiation receipts } \\
\hline Bulgaria & -5.8 & -6.3 & -12.7 & -2.5 & 0.9 \\
\hline Croatia 1/ & 1.8 & -0.7 & -0.4 & -1.2 & 0.5 \\
\hline Crech Rep & 0.4 & 0.2 & -0.4 & -1.4 & -1.4 \\
\hline Hungary & -8.6 & -6.2 & -3.1 & -4.8 & -4.6 \\
\hline Romania & -1.9 & -2.6 & 4.0 & -3.6 & -3.5 \\
\hline Slovakia & -1.3 & 0.4 & -1.3 & -5.2 & -6.0 \\
\hline Slovenia & -0.2 & 0.1 & 0.2 & -1.1 & -0.6 \\
\hline Poland & -3.0 & -3.1 & -3.3 & -3.1 & -3.3 \\
\hline CEE Average & -2.3 & -2.3 & -3.1 & -2.8 & -2.3 \\
\hline EU-15 & $\cdots$ & $\cdots$ & $\cdots$ & $\ldots$ & $\ldots$ \\
\hline \multicolumn{6}{|c|}{ Balance excluding privatization receipts } \\
\hline Bulgaria & -5.8 & -6.5 & -12.9 & -5.7 & -0.8 \\
\hline Croatia 1/ & 1.4 & -1.7 & -1.8 & -2.1 & -1.5 \\
\hline Czech Rep & -1.1 & -0.9 & -2.3 & -2.3 & -1.6 \\
\hline Hungary & -8.6 & -60.0 & -11.5 & -19.3 & -6.4 \\
\hline Romania & -1.9 & -2.6 & -4.0 & -4.6 & -5.5 \\
\hline Slovakia & -1.3 & -1.3 & -3.1 & -7.7 & -7.9 \\
\hline Slovenia & $\ldots$ & $\ldots$ & $\ldots$ & $\ldots$ & $\ldots$ \\
\hline Poland & -3.8 & -3.9 & -4.3 & -4.5 & -4.6 \\
\hline CEE Average & -3.0 & -11.0 & -5.7 & -6.6 & -4.0 \\
\hline EU-15 & -5.3 & -5.2 & 4.2 & -2.5 & -2.1 \\
\hline \multicolumn{6}{|c|}{ Expenditure and Net Lending } \\
\hline Bulgaria & 45.7 & 42.4 & 45.2 & 34.2 & 35.9 \\
\hline Croatia $1 /$ & 44.1 & 48.9 & 50.7 & 49.8 & 52.1 \\
\hline Czech Rep & 41.9 & 41.5 & 40.7 & 40.6 & 40.3 \\
\hline Hungary & 59.6 & 53.8 & 49.3 & 49.7 & 46.9 \\
\hline Romania & 33.9 & 34.7 & 33.9 & 34.2 & 38.3 \\
\hline Slovakia & 47.8 & 46.6 & 49.0 & 50.1 & 48.3 \\
\hline Slovenia & 46.1 & 45.7 & 44.9 & 44.8 & 43.8 \\
\hline Poland & 47.1 & 46.3 & 45.7 & 45.3 & 44.0 \\
\hline CEE Average & 45.8 & 45.0 & 44.9 & 43.6 & 43.7 \\
\hline EU-15 & 51.9 & 51.5 & $\$ 1.1$ & 49.8 & 48.8 \\
\hline
\end{tabular}

Sources; WEO and IMF staff estimates.

1/ Cash basis. 
Table 2. Croatia: General Government Subsidies and Transfers, 1994-99

(In percent of GDP)

\begin{tabular}{|c|c|c|c|c|c|c|}
\hline & 1994 & 1995 & 1996 & 1997 & 1998 & $\begin{array}{c}1999 \\
\text { Revised } \\
\text { Budget }\end{array}$ \\
\hline $\begin{array}{l}\text { Current and capital transfers and subsidies } \\
\text { Of which to: }\end{array}$ & 13.8 & 16.8 & 20.2 & 21.3 & 20.8 & $23.32 /$ \\
\hline Agriculture & 0.5 & 0.5 & 0.5 & 0.5 & 0.8 & 0.7 \\
\hline Railways & 1.3 & 1.1 & 1.2 & 1.1 & 1.2 & 1.0 \\
\hline Tourism & 0.0 & 0.0 & 0.0 & 0.0 & 0.1 & 0.1 \\
\hline Ports and shipping & $\ldots$ & 0.2 & 0.2 & 0.4 & 0.2 & 0.2 \\
\hline Enterprise restructuring and rehabilitation & $\ldots$ & $\ldots$ & 0.0 & 0.5 & 0.5 & 0.2 \\
\hline Bus and air transport & $\ldots$ & $\ldots$ & 0.0 & 0.0 & 0.0 & 0.1 \\
\hline Bank rehabilitation agency & 0.0 & 0.0 & 0.0 & 0.0 & 0.0 & 0.8 \\
\hline War veterans, invalids and civil war victims $1 /$ & $\ldots$ & 0.9 & 1.2 & 1.8 & 1.9 & 2.2 \\
\hline Reconstruction & $\ldots$ & 0.8 & 1.6 & 1.2 & 1.0 & 0.9 \\
\hline $\begin{array}{l}\text { Abroad } \\
\text { Of which: To Bosnia and Herzegovina 4/ }\end{array}$ & $\begin{array}{r}0.1 \\
\ldots\end{array}$ & $\begin{array}{r}0.1 \\
\ldots\end{array}$ & 0.1 & $\begin{array}{r}0.1 \\
\ldots\end{array}$ & $\begin{array}{r}0.1 \\
\ldots\end{array}$ & $\begin{array}{l}0.53 / \\
0.4\end{array}$ \\
\hline Other transfers and subsidies & 12.0 & 13.2 & 15.6 & 15.7 & 15.1 & 16.6 \\
\hline
\end{tabular}

Sources: Ministry of Finance and IMF staff estimates.

1/ For 1994-96, excludes transfers to veterans and the Croatian army by the pension fund, which are included under other current transfers.

2/ Estimate based on subsiclies and current transfers of the central government and extrabudgatary funds.

$3 /$ Consolidated central budget only.

4/ Not separately identified in the 1994-98 budget presentations. 
Table 3. Croatia: Consolidated Central Government Expenditure by Function, 1994-99

(In percent of GDP)

\begin{tabular}{|c|c|c|c|c|c|c|}
\hline & 1994 & 1995 & 1996 & 1997 & 1998 & $\begin{array}{c}1999 \\
\text { Revised } \\
\text { Budget }\end{array}$ \\
\hline Total expenditure & 40.3 & 44.7 & 44.8 & 44.0 & 45.6 & 49.3 \\
\hline General public services & 1.9 & 1.9 & 1.8 & 1.8 & 2.4 & 2.5 \\
\hline Defense affairs & 8.0 & 9.2 & 6.3 & 4.9 & 4.5 & 3.2 \\
\hline Public order and safety & 2.9 & 3.0 & 3.0 & 3.0 & 2.7 & 2.7 \\
\hline Social spending & 20.6 & 23.0 & 24.3 & 25.0 & 25.7 & 28.3 \\
\hline Education & 2.9 & 2.9 & 2.9 & 2.9 & 3.0 & 3.6 \\
\hline Health & 5.6 & 6.3 & 6.6 & 5.8 & 6.5 & 6.5 \\
\hline Social security and welfare & 12.2 & 13.8 & 14.9 & 16.4 & 16.3 & 18.2 \\
\hline Of which: & 8.9 & 12.0 & 12.9 & 14.4 & 14.4 & 16.2 \\
\hline Sickness and maternity benefits & 0.7 & 1.1 & 1.5 & 1.6 & 1.5 & 1.6 \\
\hline Unemployment benefits & 0.2 & 0.3 & 0.4 & 0.4 & 0.3 & 0.2 \\
\hline Child benefits & 0.7 & 0.8 & 0.8 & 0.8 & 0.7 & 0.9 \\
\hline Expenses for refugees and others affected by civil war & $\ldots$ & 1.2 & 1.0 & 0.9 & 0.7 & 0.4 \\
\hline Pensions (retirement, disability, veterans, widows) & 7.2 & 8.5 & 9.3 & 10.7 & 11.2 & 13.1 \\
\hline Housing and community amenities & 1.1 & 2.1 & 3.2 & 2.6 & 2.8 & 2.4 \\
\hline Recreation, culture, and religion & 0.4 & 0.4 & 0.4 & 0.4 & 0.4 & 0.6 \\
\hline Fuel and energy & 0.0 & 0.0 & 0.0 & 0.0 & 0.0 & 0.0 \\
\hline Agriculture, forestry, fishing, hunting & 0.7 & 0.5 & 0.5 & 0.5 & 0.8 & 0.8 \\
\hline Mining, manufacturing, construction & 0.2 & 0.3 & 0.4 & 0.6 & 0.5 & 1.9 \\
\hline Transport and communications & 2.6 & 2.3 & 3.2 & 2.8 & 2.9 & 3.3 \\
\hline Other & 0.3 & 0.2 & 0.3 & 0.5 & 0.4 & 0.5 \\
\hline Expenditure not classified & 1.6 & 1.8 & 1.7 & 2.0 & 2.4 & 3.2 \\
\hline
\end{tabular}

Sources: Ministry of Finance; and IMF staff estimates. 
Table 4. Government Sector Social Spending in CEE Countries, 1997-98

(In perceet of GDP)

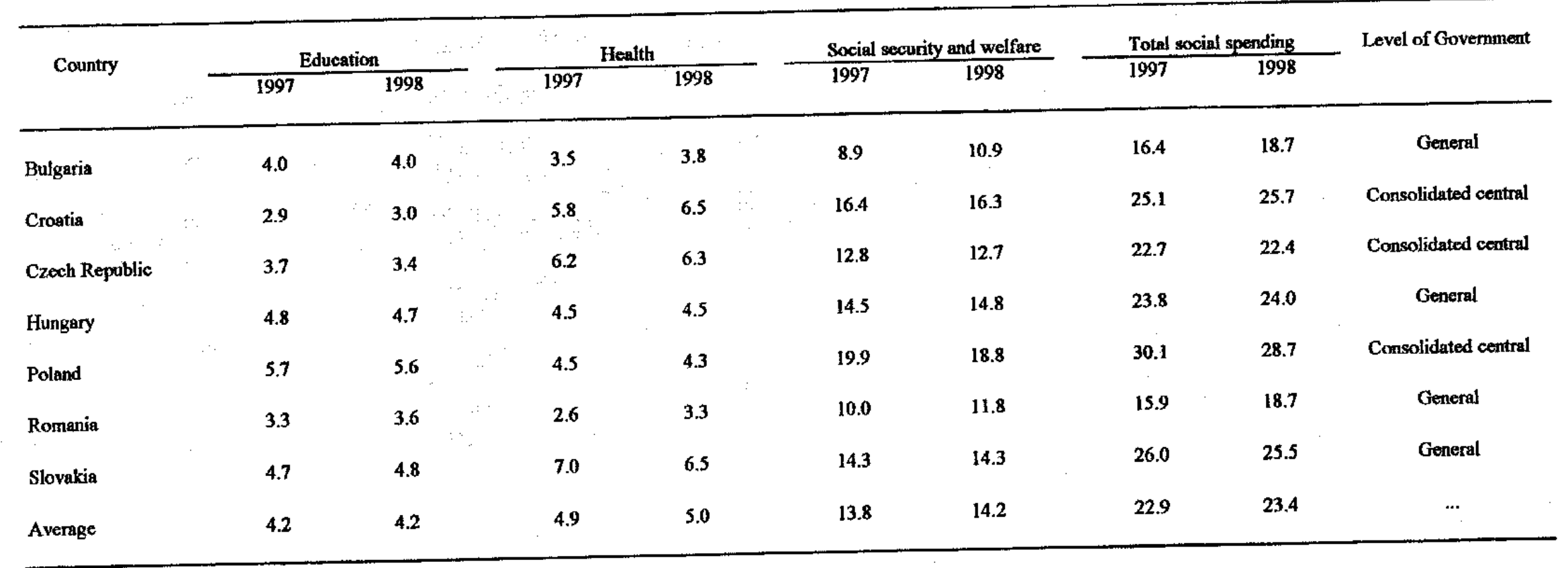

Sources: Govemment Finance Statistics and IMF country desks. 
Table 5. Croatia: Number of Beneficiaries and Pension Payments by the Croatian Pension Institute

\begin{tabular}{|c|c|c|c|c|c|c|c|c|}
\hline & 1993 & 1994 & 1995 & 1996 & 1997 & 1998 & $\begin{array}{l}1999 \\
\text { I-VIII }\end{array}$ & $\begin{array}{c}2000 \\
\text { authorit's } \\
\text { proj. }\end{array}$ \\
\hline & \multicolumn{8}{|c|}{$\begin{array}{l}\text { Number of Beneficiaries } \\
\text { (in units) }\end{array}$} \\
\hline Total & 784,364 & 813,982 & 837,931 & 844,698 & 907,420 & 938,648 & 992,162 & $1,044,850$ \\
\hline Old age & 409,122 & 433,180 & 443,688 & 451,046 & 467,363 & 487,432 & 502,261 & 526,000 \\
\hline Disability & 181,614 & 184,989 & 193,654 & 197,049 & 207,859 & 212,753 & 230,759 & 246,000 \\
\hline Survivors & 193,628 & 195,813 & 200,589 & 196,603 & 202,806 & 212,109 & 206,285 & 214,000 \\
\hline Croatian army and war veterans $1 /$ & $\ldots$ & $\ldots$ & $\ldots$ & $\ldots$ & $\ldots$ & $\ldots$ & 26,184 & 32,200 \\
\hline Total & 2,922 & 6,152 & 7,571 & 8,401 & 12,290 & 14,034 & 9,842 & $\ldots$ \\
\hline Old age & 1,756 & 3,698 & 4,412 & 4,758 & 6,648 & 7,493 & 5,175 & $\ldots$ \\
\hline Disability & 593 & 1,246 & 1,649 & 1,970 & 2,944 & 3,341 & 1,873 & $\ldots$ \\
\hline Survivors & 572 & 1,208 & 1,511 & 1,673 & 2,435 & 2,904 & 1,460 & $\ldots$ \\
\hline Croatian army and war veterans $1 /$ & $\ldots$ & $\ldots$ & $\ldots$ & $\ldots$ & $\ldots$ & $\ldots$ & 1,109 & $\ldots$ \\
\hline \multirow[t]{2}{*}{ Other-other formers SFRY republics $2 /$} & $\cdots$ & $\cdots$ & $\cdots$ & $\ldots$ & 263 & 294 & 224 & $\ldots$ \\
\hline & \multicolumn{6}{|c|}{$\begin{array}{l}\text { Annual Pension Benefits and Wages } \\
\text { (in kuna) }\end{array}$} & & \\
\hline Other-other formers SFRY republics 2/ & $\cdots$ & $\cdots$ & $\cdots$ & $\cdots$ & 8,946 & 11,166 & $12,6] 7$ & $\ldots$ \\
\hline \multicolumn{9}{|l|}{ Memorandum items } \\
\hline average replacement rate 3 / & 58.0 & 50.4 & 41.4 & 40.8 & 47.5 & 46.5 & 41.2 & $\ldots$ \\
\hline old age replacement rate $4 /$ & 66.8 & 57.0 & 45.6 & 43.3 & 49.9 & 47.8 & 42.8 & $\ldots$ \\
\hline
\end{tabular}

Sources: Pension Insurance Fund, Bureau of Statistics, and MF staff calculations.

1/ Before 1999 Croatian army and war veterans were not separately identified. According to the Ministry of Finance, pension payments to war veterans were Hrk 1.1 billion and Hrk 1.4 billion in 1997 and 1998, respectively, and the number of beneficiaries increased significantly over time.

2/ Before 1996 the number of beneficiaries from other former SFRY republics were not separately identified.

$3 /$ Average pension divided by average net wage.

4/ Old age pension divided by average net wage. 
Table 6. Consolidated General Government Revenue and Expenditure by Level of Government, 1994-9

\begin{tabular}{|c|c|c|c|c|c|c|c|c|c|c|}
\hline & $\begin{array}{c}1994 \\
\text { Actual }\end{array}$ & $\begin{array}{l}1995 \\
\text { Aotual }\end{array}$ & $\begin{array}{l}1996 \\
\text { Aotual }\end{array}$ & $\begin{array}{l}1997 \\
\text { Aotual }\end{array}$ & $\begin{array}{c}1998 \\
\text { Actual }\end{array}$ & $\begin{array}{l}1994 \\
\text { Actuol }\end{array}$ & $\begin{array}{c}1995 \\
\text { Actral }\end{array}$ & $\begin{array}{l}1996 \\
\text { Actual }\end{array}$ & $\begin{array}{l}1997 \\
\text { Actual }\end{array}$ & $\begin{array}{c}1998 \\
\text { Actuol }\end{array}$ \\
\hline & \multicolumn{5}{|c|}{ (percent of GDP) } & \multicolumn{5}{|c|}{ (percent of total) } \\
\hline Total revenuse and grants & 46.0 & 48.2 & 50.4 & 48.6 & 52.6 & 100.0 & 100.0 & 100.0 & 100.0 & 100.0 \\
\hline Budgetary central government & 26.5 & 28.3 & 29.0 & 27.3 & 31.7 & 57.6 & 58.8 & 57.7 & 56.2 & 60.2 \\
\hline Extrabudgetary funds & 15.6 & 15.4 & 15.6 & 15.6 & 15.2 & 34.0 & 32.0 & 31.1 & 32.1 & 29.0 \\
\hline Pension fund & 3.9 & 8.8 & 8.8 & 8.8 & 7.7 & 17.7 & 18.2 & 17.5 & 18.2 & 14.6 \\
\hline Health insurance fund & 4.3 & 4.6 & 4.8 & 4.7 & 5.9 & 9.3 & 9.5 & 9.5 & 9.6 & 11.2 \\
\hline Employment fund & 0.6 & 0.7 & 0.6 & 0.5 & 0.5 & 1.4 & 1.5 & 1.2 & 1.0 & 1.0 \\
\hline Child benefit fund & 0.8 & 0.8 & 0.8 & 0.8 & 0.4 & 1.7 & 1.6 & 1.6 & 1.6 & 0.7 \\
\hline Public water management fund & 0.5 & 0.6 & 0.6 & 0.8 & 0.8 & 1.1 & 1.2 & 1.3 & 1.7 & 1.5 \\
\hline Croatian road fund 2 & 1.3 & $\ldots$ & $\ldots$ & $\ldots$ & $\ldots$ & 2.8 & $\ldots$ & $\ldots$ & $\ldots$ & $\ldots$ \\
\hline Local government & 3.9 & 4.4 & 5.7 & 5.7 & 5.7 & 8.4 & 9.2 & 11.3 & 11.6 & 10.8 \\
\hline Tratsl expenditure nod net lendln & 44.1 & 48.9 & 50.7 & 49.8 & 52.1 & 100.0 & 100.0 & 100.0 & 100.0 & 100.0 \\
\hline Budgelary central government & 23.6 & 26.5 & 25.4 & 23.5 & 24.3 & 53.4 & 54.1 & 50.0 & 47.2 & 46.6 \\
\hline Extrubudgetary finds & 16.9 & 18.3 & 19.7 & 20.6 & 21.8 & 38.2 & 37.3 & 38.8 & 41.4 & 41.8 \\
\hline Pention fund & 7.6 & 9.0 & 9.7 & 11.1 & 11.7 & 17.3 & 18.4 & 19.1 & 22.4 & 22.4 \\
\hline Health insuranoe fund & 6.0 & 7.2 & 7.7 & 7.1 & 7.8 & 13.6 & 14.7 & 15.3 & 14.2 & 15.0 \\
\hline Employment fund & 0.5 & 0.5 & 0.6 & 0.6 & 0.4 & 1.1 & 0.9 & 1.2 & 1.2 & 0.8 \\
\hline Child benefit fiund & 0.8 & 0.8 & 0.8 & 0.8 & 0.7 & 1.7 & 1.7 & 1.6 & 1.6 & 1.4 \\
\hline Publio water management fund & 0.6 & 0.8 & 0.9 & 1.0 & 1.1 & 1.3 & 1.6 & 1.7 & 2.1 & 2.2 \\
\hline Croutian road find 2 & 1.4 & $\ldots$ & $\ldots$ & $\ldots$ & $\ldots$ & 3.1 & $\ldots$ & $\ldots$ & ... & $\ldots$ \\
\hline Local government & 3.7 & 4.2 & 5.7 & 5.7 & 6.0 & 8.4 & 8.6 & 11.2 & 11.4 & 11.6 \\
\hline Oversill balance & 1.8 & -0.7 & -0.4 & -1.2 & 0.5 & 100.0 & 100.0 & 100.0 & 100.0 & 100.0 \\
\hline Budgetary central government & 2.9 & 1.9 & 3.7 & 3.8 & 7.4 & 158.2 & -264.2 & -999.1 & -315.4 & 1504.8 \\
\hline Extrabudgetary funds & .1 .2 & -2.8 & -4.1 & .5 .0 & -6.5 & -67.5 & 398.1 & 1097.9 & 412.6 & -1332.2 \\
\hline Pension fund & 0.5 & -0.2 & -0.9 & -23 & -4.0 & 26.8 & 30.5 & 239.3 & 191.6 & -822.6 \\
\hline Health insuremce fund & -1.7 & -2.6 & -3.0 & -2.4 & -1.9 & -94.5 & 366.2 & 802.4 & 198.5 & -384.7 \\
\hline Employment fund & 0.2 & 0.2 & 0.0 & -0.1 & 0.1 & 8.8 & -35.0 & 0.6 & 5.5 & 20.2 \\
\hline Child benefit fund & 0.0 & 0.0 & 0.0 & 0.0 & -0.4 & 1.5 & 5.5 & -6.3 & 1.8 & -72.1 \\
\hline Public water management fund & -0.1 & -0.2 & -0.2 & -0.2 & -0.4 & -4.5 & 30.9 & 61.9 & 15.3 & -72.9 \\
\hline Crontian road find 2 & -0.1 & $\ldots$ & $\ldots$ & $\cdots$ & $\ldots$ & -5.6 & $\ldots$ & $\ldots$ & $\ldots$ & $\ldots$ \\
\hline Local government & 0.2 & 0.2 & 0.0 & 0.0 & -0.4 & 9.3 & -33.9 & 1.2 & 28 & -72.6 \\
\hline
\end{tabular}

Source: Ministry of Finanoe.

$1 /$ Includes the central budget, the extrabuigetary funds and locat governments.

$2 /$ Inoluded in the contral budget nince 1995. 
Table 7. Comparison of General Government Revenues in Selected CEE Countries, 1998 (In percent of GDP)

\begin{tabular}{|c|c|c|c|c|c|c|c|c|c|}
\hline & Bulgaria & Croatia & $\begin{array}{c}\text { Czech } \\
\text { Reptiblic }\end{array}$ & Hungary & Poland & Romania & Slovakia & Slovenia & $\begin{array}{c}\text { Average } \\
\text { excl. Croatia }\end{array}$ \\
\hline General government revenue $1 /$ & 36.9 & 50.6 & 41.5 & 43 & 40.7 & 32.8 & 42.4 & 43.1 & 40.1 \\
\hline Tax revenue & 31.4 & 46.6 & 36.8 & 41.4 & 39.1 & 30.7 & 37.1 & 40.2 & 36.6 \\
\hline Personal income tax & 4.7 & 5.8 & 5.2 & 6.4 & 8.2 & 5.5 & 5.9 & 6.6 & 5.8 \\
\hline Social security contributions & 7.7 & 13.9 & 15.6 & 13.2 & 12.5 & 8.8 & 14 & 13.8 & 12.2 \\
\hline VAT & 8.5 & 14.6 & 6.6 & 7.8 & 7.8 & 6.6 & 7.7 & $14.82 /$ & 8.6 \\
\hline Corporate income tax & 4 & 2.5 & 3.7 & 2.1 & 2.8 & 3.3 & 3.6 & 1.2 & 3.0 \\
\hline
\end{tabular}

Source: IMF country desks.

1/ Excluding privatization.

2/ Revenue from goods and services tax. 
Table 8. Selected Tax Rates in CEE Countries in 1999

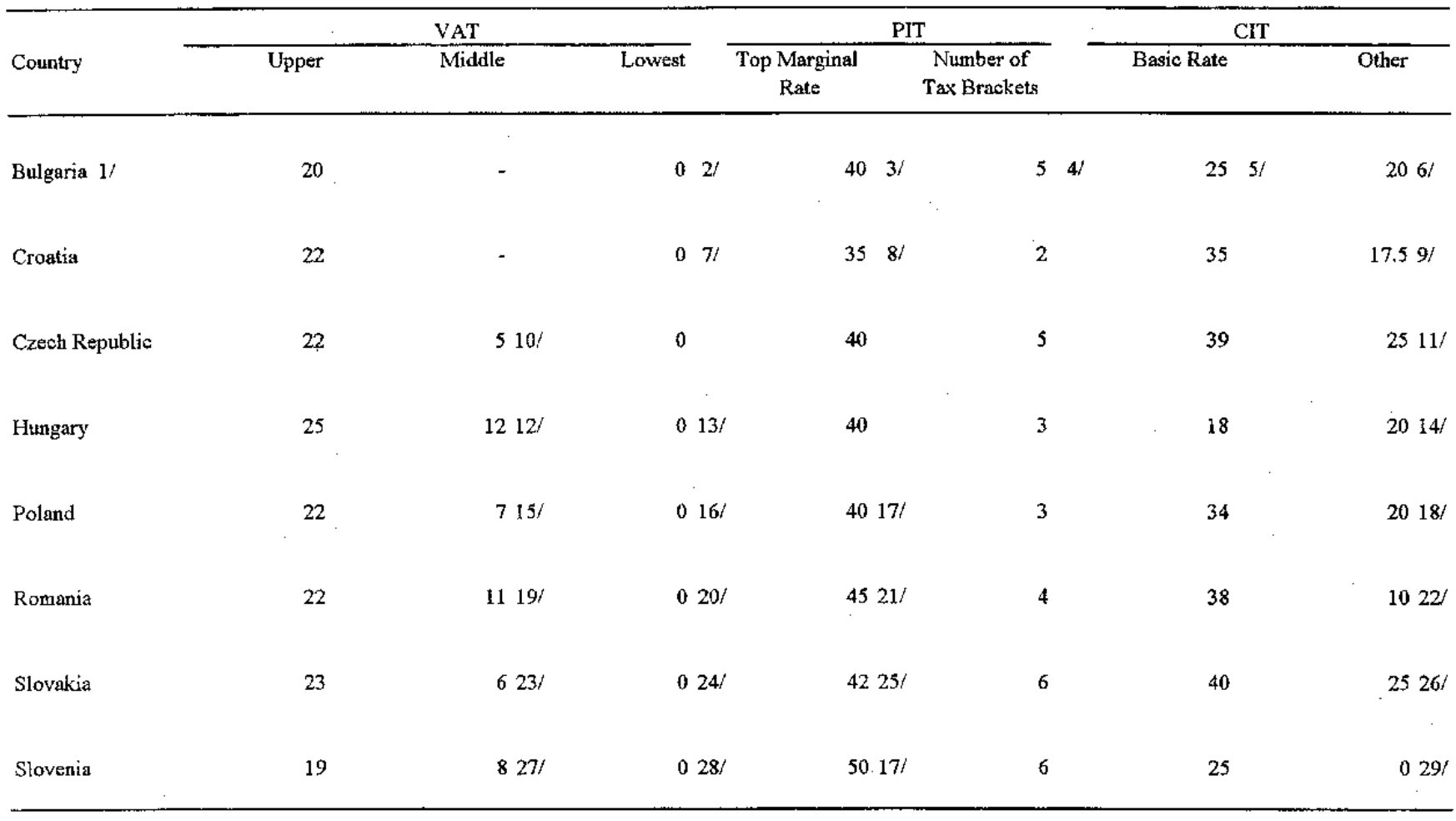

Source: International Bureau of Fiscal Documentation, "Taxation and Investment in Central and East Europcan Countries," various editions.

1/ From January 1, 2000.

2/ Applies only to exports.

3/ Separate schedules apply to wages and other seurces of income. Both schedules have the same tax rates, but the wage tax is more progressive.

4/ Including zero bracket.

5/ An additional 1.0 percent muricipal tax is also levied.

6/ Lower rate applies to companies with taxable profit of less than BGL50 million.

$7 /$ Applies to financial and medical services, and real estate transactions and, since November 1999, to books, milk, bread, and prescription drugs provided by the heaith fund.

8/ Excluding income tax surcharges levied by cities (up to 60 percent in Zagreb and 30 percent in other cities). Actual rates are currently between 6 and 18 percent. 9/ Applies to enterprises in war affected regions.

10/ Applies to basic foodstuffs, all services, real estate and construction works.

11/ Applies to profits of investment and pension funds.

12/ Applies to basic foodstuffs and household electricity.

13/ Applies to textbooks, certain medicines and medical products, and construction.

14/ Dividend withholding tax.

15/ Applies to building materials, pharmaceuticals, medical devices, tourism.

16/ Applies to Basic foodstuffs and health services.

$17 /$ Interest income is tax exempt.

18/ Withholding tax applies to dividends and interest.

19/ Applies to bread.

20/ Household consumption of electricity and gas exempted.

21/ Wage tax. Different schedules (with different tax rates) apply to other sources of income.

22/ On dividends and interest. Income from services is taxed at 15 percent.

23/ Applies to basic foodstuffs, pharmacenticals, electricity, and legal services.

24/ Postal, financial, education and health services.

25/ Capital income is not taxed.

26/ Withhoiding tax applies to royalties, rental income, and income of independent artists.

$27 / \Lambda$ pplies to food, transport, printed material, medical services and publio hygiene.

28/ Applies to insurance and financial services.

29/ Applies to interest from securities issued by state or lowal goveruments or publiv companies, and other exemptions. 
Table 9. Payroll Taxes in Selected CEE Countries in 1999

(In percentage points)

\begin{tabular}{|c|c|c|c|c|c|c|c|}
\hline Country & Pention & Henlth & Unemployment & Other & Total & $\begin{array}{l}\text { Employer's } \\
\text { Contribution }\end{array}$ & Base \\
\hline Bulgaria 1/ & 35.7 & 6.2 & 4 & $12 y$ & 46.9 & 37.7 & $\begin{array}{l}\text { Gross wages including } \\
\text { in-kind benefits. }\end{array}$ \\
\hline Croatia & 21.5 & 18 & 1.7 & $0.49 /$ & 41.6 & 21.0 & Gross wages and salaries \\
\hline Czech Republic & 26 & 13.5 & 3.6 & $4.43 /$ & 47.5 & 35 & $\begin{array}{l}\text { Gross salaries (for employees); } \\
\text { other income (for entrepreneurs) }\end{array}$ \\
\hline Hungary $4 /$ & 30 & $145 /$ & 5.5 & - & 49.5 & 37 & Gross remuneration \\
\hline Poland & 32.5 & $2.45+(0.4-8.12) 6 /$ & 2.45 & $0.087 /$ & $37.5+(0.4-8.12)$ & 18.8 & $\begin{array}{l}\text { Gross salary, including } \\
\text { in-kind benefits. }\end{array}$ \\
\hline Romania & $37.58 /$ & 14 & 5 & - & 56.5 & 40.5 & $\begin{array}{l}\text { Gross salary, incluwing } \\
\text { in-kind benefits. }\end{array}$ \\
\hline Slovakia & 32.3 & 13.7 & 4 & - & 50 & 38 & Gross wages \\
\hline Slovenia & 24.35 & 13.25 & 0.2 & $0.210 /$ & 38 & 15.9 & Gross payments. \\
\hline
\end{tabular}

Source: Internationsl Bureau of Fiscal Documentation, "Taxation and Investment in Central and East European Countries, "various editions.

1/ From January 1, 2000. Reduced rates apply to employment in apecific industries.

$2 /$ For work-related illness and maternity benefits.

3/ Sickness and other benefits.

4/ From January 1, 1999.

3/ An additional lump sum health care levy of KIJF 3,600 per month paid by employers applies.

6/ Contributions for injury insurance vary by type of employment.

$7 /$ Contribution to fund to pay wages in the event of insolvency of employer.

8/ For standard working conditions. A 10 percentage point premium is added for arduous labor conditions.

9/ Contribution to the Chamber of Commence.

10/ Maternity benefits. 
Table 10. Total Debt of the Consolidated Central Government in Selected CEE Countries, 1994-98 1/

(In percent of GDP)

\begin{tabular}{|c|c|c|c|c|c|}
\hline & 1994 & 1995 & 1996 & 1997 & 1998 \\
\hline Bulgaria & $\ldots$ & 100.9 & 105.8 & 104.4 & 84.3 \\
\hline Croatia & $\ldots$ & 28.2 & 27.6 & 26.5 & 24.521 \\
\hline Czech Republic & 13.3 & 11.2 & 9.9 & 10.3 & 10.7 \\
\hline Hungary & 85.1 & 84.3 & 71.5 & 62.9 & 60.4 \\
\hline Poland & 88.8 & 68.0 & 54.6 & 46.5 & 43.8 \\
\hline Romania & $\ldots$ & 16.0 & 22.7 & 27.3 & 28.4 \\
\hline Slovakia & 29.6 & 26.1 & 24.8 & 27.1 & 30.6 \\
\hline Slovenia & 21.1 & 18.5 & 18.7 & 22.8 & 23.2 \\
\hline Average & 47.6 & 44.2 & 41.9 & 41.0 & 38.2 \\
\hline $\begin{array}{l}\text { Memorandum item: } \\
\text { Croatia's consolidated } \\
\text { central government debt, } \\
\text { including public guarantees }\end{array}$ & $\ldots$ & $\ldots$ & $\ldots$ & 31.1 & $36.23 /$ \\
\hline
\end{tabular}

Source: WEO and IMF country desks.

1/ Excluding government guarantees.

2/ At end September 1999, Croatia's government debt increased to 30.5 percent of GDP.

3/ At end September 1999, the sum of Croatia's government debt and public guarantees was 45.2 percent of GDP. 


\section{RECENT DEVELOPMENTS IN CROATIA'S FINANCIAL SECTOR ${ }^{1}$}

\section{A. Introduction}

35. During the 1990s, Croatia has made significant progress in developing a modern financial sector. Banks recovered from a state of near-bankruptcy at the time of independence, money and capital markets were established, and a market-oriented legal framework was introduced. However, the nonbank financial sector remains small and numerous banks experienced severe problems in 1998 and early 1999. This chapter discusses recent developments in the Croatian financial sector. The first section looks at the banking sector, focusing on recent problems, assessing the response of the central bank, and describing the remaining policy agenda. The second section is dedicated to the nonbanking sector and analyzes recent trends and policy needs in the insurance, money, and capital markets.

\section{B. Croatia's Banking Sector}

36. Croatia has a modern two-tier banking system which, in November 1999, comprised 48 fully licensed universal banks, 12 representative offices and licensed branches of foreign banks, and 41 other institutions providing a somewhat more limited range of financial services. ${ }^{2}$ Commercial banks dominate in terms of size, accounting for almost all of the total assets of the banking system. All banks are supervised by the Croatian National Bank (CNB). Although most are privately owned and some foreign owned, the state still holds a majority stake in nearly all of the largest banks (Table 11). Privatization procedures are, however, at an advanced stage, and on December 17 it was announced that a majority share in the country' second largest bank had been sold to an Italian bank.

37. Reforming the system has been a lengthy and costly process fraught with many of the difficulties faced by other transition countries. In a market economy, banks play a crucial role in mobilizing and allocating savings. Establishing a modern banking sector and ensuring the conditions for its long-term development have, therefore, been key goals of the transition process. These objectives, however, have proved elusive in several countries where poor reform sequencing, burdensome legacies from the past, weak institutions and scarce human capital have frequently led to widespread banking problems. Similar problems have marred the development of the Croatian banking sector. Following rapid growth until 1997, serious banking difficulties emerged in 1998-1999 under the cumulative effect of financial and institutional weaknesses. Public confidence in the system was shaken and banking problems contributed to the economic recession that began in late 1998. However, the recent enactment and implementation of a stronger regulatory framework, governmental action to address the

\footnotetext{
${ }^{1}$ Prepared by Åke Lönnberg and Riccardo Maggi. This chapter has benefited from helpful comments by Gary O'Callaghan.

${ }^{2}$ Four housing savings banks and 31 savings banks make up most of this group.
} 
problems of troubled banks, and the increasing participation of foreign capital have strengthened the prospects for the sound development of the banking sector.

38. This section is divided in three parts. First, developments up to 1997 are briefly reviewed, stressing the weaknesses and inefficiencies which accompanied far-reaching changes in the banking sector. The second part describes the emergence of serious banking problems in 1998 and early 1999 and analyzes the authorities' response. The section concludes with a preliminary assessment of the strategy chosen and a description of the remaining policy agenda.

\section{Early banking sector developments}

39. Following the introduction of a market-oriented legal framework in the early $1990 \mathrm{~s},{ }^{3}$ significant progress was made in establishing a modern banking system. The banking sector recovered from its state of near-bankruptcy at the beginning of transition and expanded vigorously until end-1997 (Table 12). With improved political and macroeconomic stability, savings held abroad were repatriated, boosting the resources at banks' disposal and fueling a sharp expansion in lending. The number of commercial banks rose sharply (Figure 4) and many of the smaller, newly established institutions recorded above-average rates of growth.

40. By end-1997, however, the incentives for sound bank behavior had not yet been fully established. First, public financial support was repeatedly granted to several state-owned banks in an attempt to restore their long-term viability. At end-1997, four state-owned banks, ${ }^{4}$ accounting for 32 percent of total bank assets were being financially and

\footnotetext{
${ }^{3}$ See, in particular, the 1992 Law on the National Bank of Croatia and the 1993 Law on Banks and Savings Banks. The latter relaxed entry requirements and set the basis for a sharp increase in the number of banks.

${ }^{4}$ The four banks were: Slavonska Banka (the first to enter the rehabilitation procedure in November 1995 and the first to be privatized in 1998), Riječka Banka and Splitska Banka (the two largest regional banks), and Privredna Banka (at one point the largest Croatian bank). By end-1997, their rehabilitation had implied writing off 17.3 percent of the stock of credit to enterprises and issuing deutsche mark indexed government bonds amounting to $\mathrm{HrK}$ 2.9 billion (or 2.3 percent of 1997 GDP).
} 
Figure 4. Croatia: Number of Commercial Banks by Ownership, 1991-98

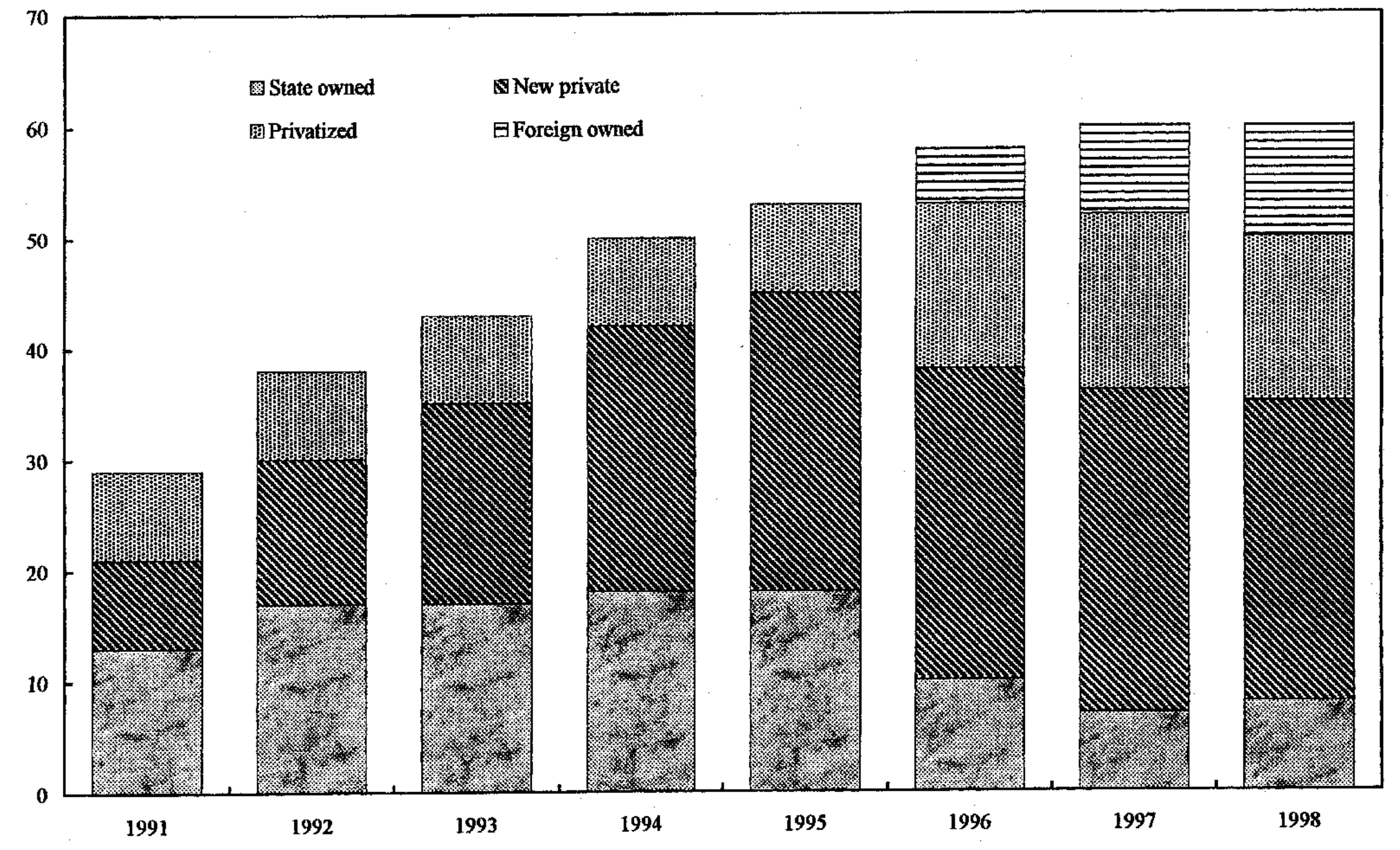

Source: Croatian National Bank. 
operationally restructured under the 1994 Law on Bank Rehabilitation. ${ }^{5}$ While these procedures successfully broke the linkages between weak state banks and loss-making state enterprises, privatization of the rehabilitated banks was only initiated in 1998. Second, private ownership of banks had not always translated into higher efficiency and sound lending policies. ${ }^{6}$ The increasing number of private banks was due to either privatization or new entry. Several banks had been privatized in a way that left the old management in control and did not break their ties with the enterprises which used to own them. ${ }^{7}$ Several new universal banks had entered the market thanks to relatively lax requirements but many appeared to be too small to achieve an efficient scale. Third, the incentives for banks to improve their efficiency had been limited in an environment where deposits grew rapidly and banks could earn high returns by lending surplus funds to the ailing state banks. Finally, the opportunities for unsound bank behavior were exacerbated by shortcomings in the prudential and legal framework ${ }^{8}$ and by a poorly designed deposit insurance scheme which provided depositors with few incentives to monitor banks' financial health. ${ }^{9}$

${ }^{5}$ This law established the so-called Bank Rehabilitation Agency (BRA) as "a specialized financial institution for the insurance of savings deposits in banks and savings banks, and for the implementation of bank rehabilitation procedures." According to the latter, a bank experiencing serious liquidity problems or suspected to be insolvent would be required to enter a 30-day period during which the CNB would assess the extent of the bank insolvency and its long-term viability. If considered nonviable, the bank would be proposed for bankruptcy. If, instead, it was considered viable, and had lost between 30 and 50 percent of its capital, the bank could be recommended for a 'voluntary' rehabilitation process on the basis of its own restructuring plan. If, however, the losses amounted to more than 50 percent of capital, the CNB could recommend mandatory rehabilitation. In either case, the final decision rested with the government. The choice to rehabilitate a bank implied writing off its capital against losses, providing new capital in the form of BRA rehabilitation bonds, replacing management, and implementing a restructuring plan under BRA supervision.

${ }^{6}$ See E. Kraft and D. Tirtiroglu, 1998, "Bank Efficiency in Croatia: A Stochastic-Frontier Analysis", Journal of Comparative Economics, Vol. 26, pp. 282-300.

${ }^{7}$ Enterprise ownership of banks was widespread in Croatia as a legacy of the previous regime. When an enterprise owning a bank was privatized, the bank also passed under private ownership. Enterprise privatization, however, often led to widely dispersed ownership and left management in control.

${ }^{8}$ See "Croatia's Banking Sector" in "Republic of Croatia: Selected Issues and Statistical Appendix", SM/98/58, 1998.

${ }^{9}$ The insurance scheme envisaged full coverage for amounts up to HrK 30,000 and 75 percent compensation for amounts between $\mathrm{HrK} 30,000$ and $\mathrm{HrK} \mathrm{50,000.} \mathrm{Insurance} \mathrm{was}$ extended to all eligible accounts regardless of the financial soundness of the bank holding the deposits. Moreover, in July 1998, a decree of the Ministry of Finance extended full coverage to amounts up to $\mathrm{HrK} 100,000$ per individual and bank. 
41. All of these factors raised concerns about the efficient allocation of the sharply growing stock of loans and the vulnerability of individual banks as the entry of foreign banks and the end of the easy financing provided by savings repatriation raised the pressures of competition. ${ }^{10}$ While some banks appeared to be better equipped than others to cope with a more competitive environment, risk management capabilities, related-party lending, singleclient exposure, inadequate provisioning, and political interference in lending decisions were all sources of concern for the regulatory authority. ${ }^{11}$ In this context, a group of rapidly expanding middle-sized banks was identified as potentially vulnerable. ${ }^{12}$

\section{The banking crisis and the CNB response}

42. A significant segment of the Croatian banking system came under stress in 1998 when several banks turned out to be vulnerable to adverse macroeconomic developments. Monetary tightening, the weakening economy, and a drying-up of repatriated savings exposed the underlying insolvency of a group of rapidly growing institutions. In addition, deficiencies in banking legislation contributed to a perception of indecisiveness on the part of the supervisory authority, making it difficult to deal with the emerging problems and raising fears about the financial health of the sounder banks. The resulting loss of confidence contributed to a weakening of base money demand, an outflow of official reserves, and a resurgence of currency substitution. ${ }^{13}$ However, the entry into effect of a new banking law in late 1998 allowed a more decisive response by the CNB during 1999, thus halting these negative trends and initiating the resolution of banking problems.

43. Although the underlying weaknesses in several banks became apparent in the course of 1998 , the existing legal framework did not allow the CNB to take prompt supervisory action. ${ }^{14}$ In February, a fight among owners of the fifth largest bank, Dubrovačka

${ }^{10}$ The easy profit opportunities offered by lending surplus funds to the ailing state banks had also come to an end when these entered the rehabilitation procedures.

${ }^{11}$ See Croatian National Bank, "Report on the Credit Policies of Croatian Banks", July 1998 and Croatian National Bank, "The Structure and Performance of the Croatian Banking System in 1997", unpublished draft.

${ }^{12}$ See Croatian National Bank, "Banks at the Crossroads: A Report on the Banking System in the Republic of Croatia", September 1997.

${ }^{13}$ Base money contracted by nearly 6 percent in the year to March 1999 as the CNB's net usable reserves fell from 152 percent of base money to 122 percent. The local currency share of broad money dropped from 38 percent at end-1997 to 31 percent at end-March 1999.

${ }^{14}$ Under the 1993 banking law, the CNB's authority was limited to propose improvement measures to be implemented by the banks themselves. Even if it initiated bankruptcy proceedings, the supervisory authority could not take control of the property of a bad bank and protect its assets before the appointment of a receiver by the commercial courts. 
Banka, ${ }^{15}$ led to rumors about the bank's insolvency and prompted a run on deposits. After receiving initial liquidity support from the $\mathrm{CNB}$, the bank was renationalized and subjected to rehabilitation. ${ }^{16}$ By June, the liquidity position of the sixth largest bank, Glumina Banka, had also seriously deteriorated. As a condition for CNB support, the bank requested to be rehabilitated. In a break with the past, however, the CNB did not recommend deeply insolvent Glumina Banka for rehabilitation, thus indicating that some banks were not too big to fail. With a more forceful legal framework under preparation, the CNB continued to step up its provision of exceptional liquidity assistance as an increasing number of banks faced mounting liquidity problems. To prepare for action after the expected approval of the new banking law, however, the CNB also contracted two foreign audit firms to examine the 1997 financial accounts of 12 banks and revise them according to international accounting standards. $^{17}$

44. The new banking law was approved in December 1998, finally allowing the CNB to take more forceful measures. The new legislation strengthened the central bank's enforcement and regulatory powers and increased the responsibilities of banks' supervisory boards. At the same time, it introduced a regime for a measured and timely response to the problems of failing and insolvent banks and established the institution of a temporary administrator ${ }^{18}$ Backed by its new powers, the CNB began implementing a more comprehensive set of measures aimed at dealing with the weaknesses of identified problem banks, which accounted for roughly a quarter of total bank assets at end-1998.

45. The first type of problem banks comprises institutions in serious financial difficulties whose closure was judged by the CNB to pose a systemic risk. This was the case of Croatia Banka, the twelfth largest bank in the country, which, early in the year, had been found

${ }^{15}$ Dubrovačka Banka had belonged to the former state network of regional banks. It was privatized in 1994 when a large portion of its shares was sold to an entrepreneur attempting to consolidate a strong position in the Dalmatian region and its hotel industry.

${ }^{16}$ Dubrovačka Banka thus became the fourth bank out of the top five to be undergoing rehabilitation. Previous rehabilitation procedures, however, had been limited to state-owned banks.

${ }^{17}$ Although off-site data had already indicated the weakness of most of the selected banks, incorrect asset classification had been a source of concern for the supervisory authority. See Croatian National Bank, "Banks at the Crossroads", 1997.

18 The temporary administrator controls the banks' assets and has the task of developing, and recommending to the CNB, a strategy for the solution of a bank's problems. The new legislation also increased minimum initial capital requirements, raised the minimum capitaladequacy ratio to ten percent, decreased maximum exposure limits to single clients and lowered the threshold for lending to connected parties expanding and clarifying its definition. The category of savings banks was abolished and all savings banks are required to meet the criteria for commercial banks by end-2001. 
insolvent by an on-site examination. Fearing the systemic consequences of a permanent closure of the bank, ${ }^{19}$ the CNB appointed a temporary administrator in February 1999, and provided continuous liquidity support. Following CNB recommendations, the government took the decision on September 23 to rehabilitate the bank and announced plans to issue some HrK 550 million in government bonds for its recapitalization.

46. The second type of problem banks accounted for 8 percent of total banking assets at end-1998 and comprised fourteen commercial and savings banks thought to be insolvent. Using the powers of the new banking law, the CNB appointed temporary administrators for all of these banks. By December 1999, bankruptcy proceedings had been initiated for eleven banks $^{20}$ and the temporary administrators of the three remaining banks ${ }^{21}$ had been instructed to take a number of measures aimed at enhancing the collection of their claims, reducing their operating costs, and increasing the prospects for a merger with a sound financial institution.

47. Finally, the CNB has taken preventive action concerning weaker, but still solvent, small banks. Supervisory agreements were negotiated and an enhanced supervision regime was instituted. By November 1999, all banks concerned were implementing the remedial actions mandated by the CNB in spite of the difficult macroeconomic environment.

48. The CNB strategy for the resolution of banking sector problems envisages the direct outlay of public funds only in certain cases, namely when recapitalizing systemically important banks, when providing incentives for a merger with a sound institution, when paying out insured deposits in bankrupt institutions, and when redeeming, in cash and on demand from the CNB, any government security used as collateral for central bank liquidity lending to failed banks. ${ }^{22}$ During 1998-99, total cash injections amounted to HrK 1.8 billion (1.3 percent of 1999 GDP), while government debt issues for bank resolution totaled $\mathrm{HrK} 2.7$ billion (1.9 percent of 1999 GDP). ${ }^{23}$

${ }^{19}$ The bank was closed for a few days in February 1999.

${ }^{20}$ These were: Ilirija, Glumina, Gradska, Komercijalna, Županjska, Gradjanska Stedionica, Neretvanska Gospodarska, Invest Štedionica, Štedionica Gold, Štedionica Mediteran, and Trovačko-Turističa.

${ }^{21}$ Agro-Obrtnička, Promdei, and Hrvatska Gospodarska Banka.

${ }^{22}$ Government securities are currently the only form of collateral allowed for liquidity lending. In the past, however, other assets could also be used. In the case of Glumina Banka, for instance, household loans constituted the collateral. Following the bank's bankruptcy, therefore, the CNB made specific provisions of HrK 290 million for 1999.

${ }^{23}$ During 1999, cash injections amounted to $\mathrm{HrK} 1.2$ billion and debt issues totaled $\mathrm{HrK} 2.1$ billion. 


\section{Preliminary assessment and remaining policy agenda}

49. The approval of a new banking law and the set of measures taken thereafter by the CNB responded to both short- and long-term concerns. Setting in motion the resolution of weaker banks' problems and restoring public confidence were the more urgent immediate goals while preventing the emergence of new problems and ensuring the sustainable development of the local banking sector constituted more long-term objectives.

50. By November 1999, the CNB had achieved most of its more immediate goals although the difficult macroeconomic environment and the multiplicity of claims on strained budget resources constituted a source of concern. Against the background of strengthening confidence, the demand for base money had recovered, growing by 6 percent in the year to November. By end-October, the local currency share of broad money had climbed back to nearly 35 percent and CNB net usable reserves had risen to 139 percent of base money by end-November.

51. Nonfailed banks, meanwhile, adopted a more prudent lending policy. Their nominal stock of loans contracted slightly during the third quarter of 1999 and credit to other domestic sectors grew by only 3.2 percent by September 1999 relative to end-1998. Still, banks' financial indicators provide some tentative evidence of a strengthening in banks' balance sheets compared to 1998 . During that year, the banking sector recorded its first loss on an aggregate basis since 1993 . $^{24}$ This was largely due to increased provisioning for bad loans $\mathrm{s}^{25}$ as the reported quality of banks' loan portfolios deteriorated (Table 13). In the first quarter of 1999, however, nonfailed banks reported a drop in the share of nonperforming risk assets and off-balance sheet items. The largest banks also seem to be recovering. Over the first six months of the year, the second largest institution reported record profits, albeit from a low base, while the largest bank continued to make significant provisions thanks to a sustained growth in gross profits.

52. Finally, the direct vulnerability of the banking sector to exchange rate movements has diminished but indirect exposure remains substantial. At end-1997, the banking sector as a whole held a significant short position in foreign exchange. By the third quarter of 1999 , however, this net short position was eliminated and all the largest banks were long in foreign exchange. ${ }^{26}$ The underlying portfolio adjustment ${ }^{27}$ contributed to the pressures on the foreign

${ }^{24}$ Total losses amounted to some HrK 1.9 billion but one bank accounted for more than half of this sum while 43 banks showed positive net profits.

${ }^{25}$ In 1998, provisioning for identified losses grew by more than fifty percent and accounted for 30 percent of banks' total costs, as opposed to 11 percent in 1997.

${ }^{26}$ These included the banks undergoing rehabilitation which, however, adjusted their portfolios later than the rest of the banking sector.

${ }^{27}$ Estimated to average between 30 and 35 percent of banks' total capital. 
exchange market but eliminated banks' direct exposure to additional kuna depreciation. However, indirect exposure remained substantial since more than sixty percent of all loans to the private sector are either indexed to or denominated in foreign currency. To the extent that these borrowers are unhedged, banks remain vulnerable to exchange rate depreciation. ${ }^{28}$

53. Fully implementing the CNB strategy towards problem banks requires achieving the prompt exit of insolvent banks, finding a solution for the systemically important banks, and taking effective preventive action. Fostering the market-driven development of the domestic banking sector, however, requires more than the resolution of current banking problems. In the medium term, there is a need to re-activate banks' lending role, ensuring a more efficient allocation of credit than in the past, and establishing incentives conducive to efficiencyenhancing investment.

54. With regard to the first medium-term objective, banks' reluctance to extend new loans could be due to several reasons, including the slower growth of loanable resources, the introduction of capital controls in early 1998, and the higher cost of borrowing on the international capital market. Moreover, in a depressed environment characterized by high interest rates and significant political and economic uncertainty, few projects are likely to offer the level of expected returns needed to obtain bank financing. Finally, banks are likely to adjust their balance sheets in a prudential response to previous excess lending and the associated decline in the quality of their assets. However, the expectations of stronger economic activity, diminished political uncertainty after the parliamentary and presidential elections in early 2000 , and the completion of banks' prudential portfolio adjustments are likely to lead to a resumption in loan growth, especially if policy adjustment improves macroeconomic conditions.

55. As for the other medium-term objectives, it is still too early to make a definitive assessment. An increasingly efficient credit allocation should be achieved as the banking system adjusts to the tougher prudential requirements introduced by the new banking law and undergoes further structural changes. Despite recent bankruptcies and mergers and acquisitions, some of the remaining smaller banks will need to find a market niche or merge to achieve a viable size. The level of concentration continues to be high, with the two biggest banks still controlling 45 percent of total banking assets at end-June 1999 (Figure 5). State involvement in the larger banks remains significant and the spread between deposit and lending rates is still high (Figure 6). Nevertheless, the exit of the bankrupt institutions, the

${ }^{28}$ Fund staff estimates indicate that, in March 1999, a 10 percent devaluation would have depleted nearly twenty-six percent of banks' capital under the extreme hypothesis that the indexation clauses on all indexed kuna loans would become immediately and totally inoperable due to borrowers' inability to pay. Thanks to portfolio adjustments, however, the estimated cost of a ten percent devaluation under the same pessimistic assumption had fallen to twenty percent of banks' capital by September 1999. It should be noted that these calculations relate to the aggregate banking system. 
Figure 5. Croatia: Assets and Liabilities of Top Five Banks by Assets, 1996-99 1/

(In percent of banking sector total)
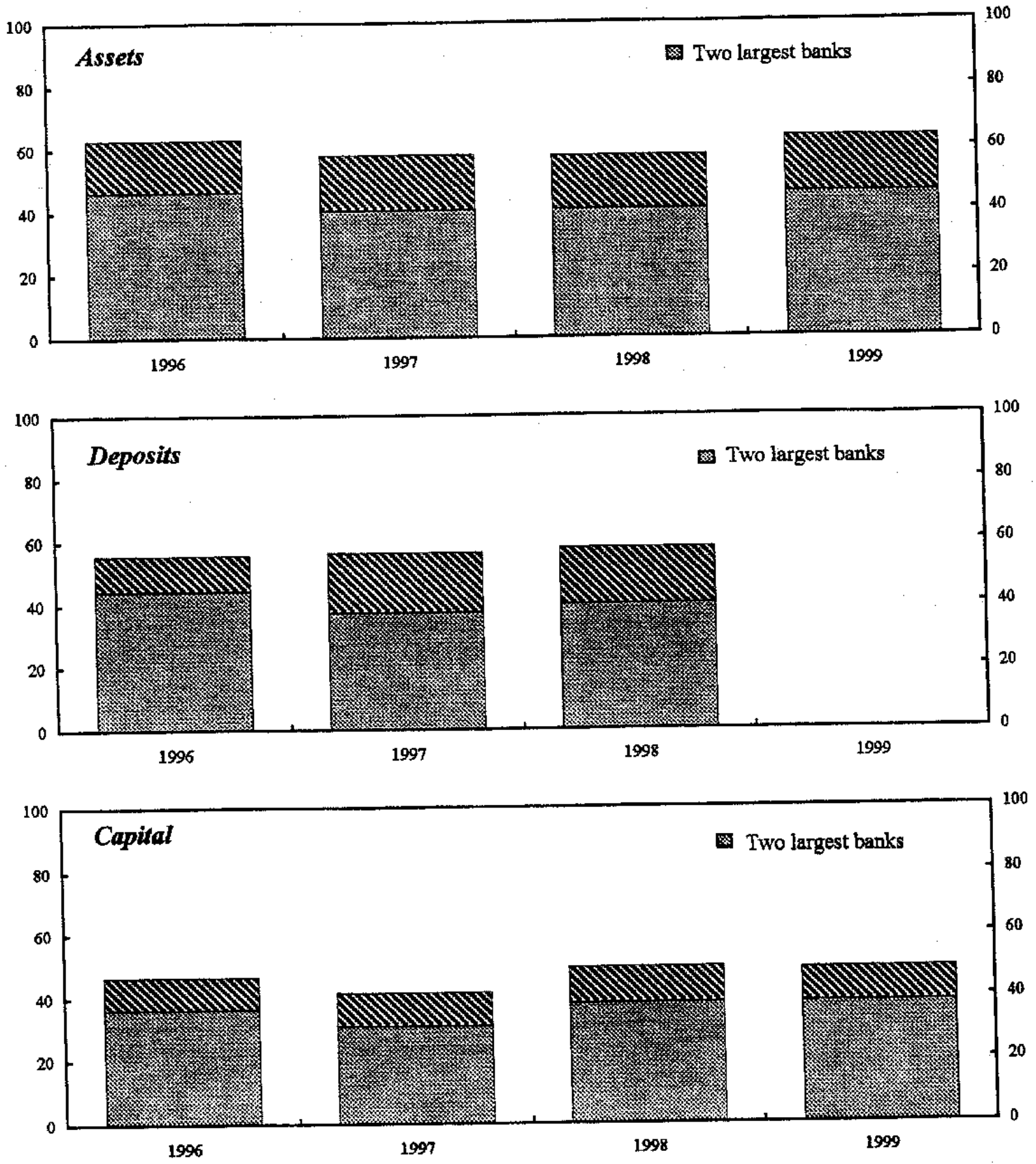

Source: Croatian National Bank.

1/ Data for 1999 refers to end-June where available. 
Figure 6. Croatia: Interest Rates, 1995-99 1/

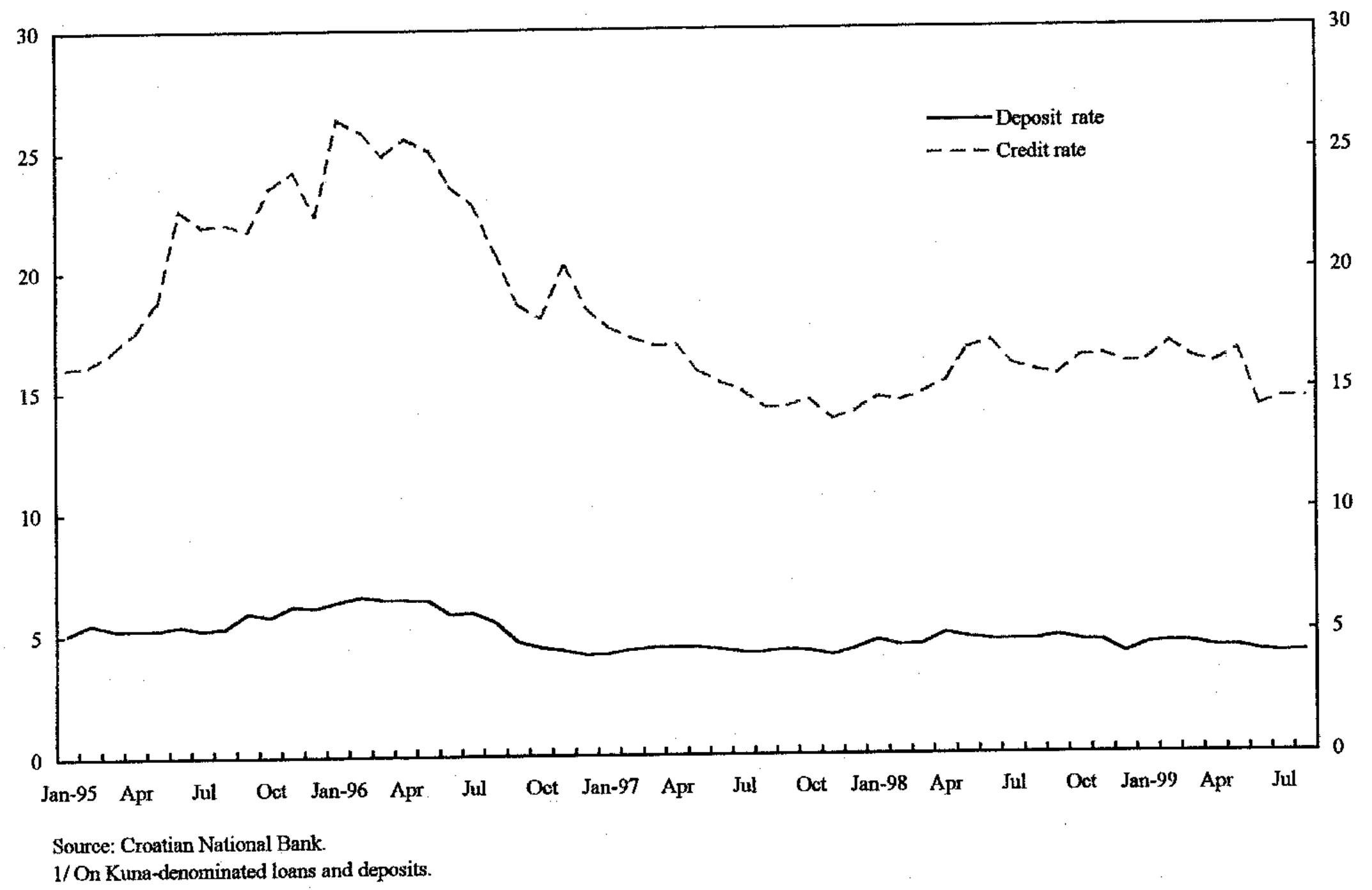


more forceful implementation of an improved supervisory framework, and the increasing dynamism of foreign banks ${ }^{29}$ have strengthened the prospects for the medium-term development of the banking sector.

56. The authorities could reinforce these trends by carrying out their commitment to phase out state ownership. Significant progress in this regard could be made in the near future given the advanced stage of the tenders for Privredna Banka, Riječka Banka, and Splitska Banka, which jointly account for more than 60 percent of all state-owned banks' assets. ${ }^{30}$ If carried out, the sale of these institutions to foreign strategic investors would lead to a significant injection of fresh capital, management skills, and advanced technology. ${ }^{31}$

57. As competitive pressures increase, strengthening the procedures for orderly market exit and restructuring will remain a key priority. Further bankruptcies of smaller banks cannot be excluded. If properly managed, however, such institutions' failure would not undermine depositors' confidence. Takeovers of weaker banks by stronger ones is another market-driven solution and could be granted limited government support as long as a merger clearly constitutes the least-cost alternative for the state budget. Finally, a long-term solution for the excessive regional exposure of some local banks is being sought. Since forcing the exit of these banks has proven to be politically difficult, the entry of new banks in regional markets as well as mergers between banks that operate in areas with different economic features could offer a solution.

58. In order to ensure a smooth consolidation process, the authorities plan to improve the quality of coordination between key institutional players, such as the BRA, the Ministry of Finance, the $\mathrm{CNB}$, and the commercial courts administering the bankruptcy cases. They also intend to abide by their commitment to settle the deposit insurance obligations arising from failed banks as promptly as possible, keeping delayed disbursements to the minimum required by the availability of funds and avoiding reliance on the issuance of illiquid government securities for payment. Finally, a reform of the deposit insurance scheme is currently under preparation. ${ }^{32}$ This could help to reduce central budget contingent liabilities

${ }^{29}$ These are recording faster-than-average growth, and three small domestic banks have been acquired by foreign institutions in late 1999.

${ }^{30}$ As noted in paragraph 2, the government accepted on December 17 an offer from Banca Commerciale Italiana to buy 66.3 percent of Privredna Banka.

${ }^{31}$ As shown in the case of Žagrebacka Banka and Privredna Banka, short of privatization itself, twinning arrangements with foreign banks can facilitate the upgrading of local management and technological skills.

${ }^{32}$ The first specific depositor protection scheme was introduced in the By-Law on Deposit Insurance of June 1997. After the modifications introduced by a decree of the Ministry of Finance in July 1998, the scheme currently insures household savings deposits up to HrK 100,000 per individual and bank. Balances in excess of this level as well as balances on checking accounts, giro accounts, and deposits of high-level staff in the bank are not covered. 
in two ways. First, the vulnerability of the current regime to currency movements can be limited by allowing the BRA to invest an appropriate share of its funds in the foreign currency to which insured deposits are indexed. ${ }^{33}$ Second, changes in the way deposit insurance is financed could decrease moral hazard. ${ }^{34}$ Differentiating the cost of deposit insurance on the basis of banks' financial soundness, for instance, would discourage them from increasing the riskiness of their assets to improve net income. Similarly, basing insurance premia on relative deposit interest rates would discourage unsound banks from offering higher interest rates to attract deposits.

59. The authorities' remaining policy agenda includes some additional items. First of all, the CNB plans to lower reserve requirements to the extent permitted by its exchange rate objective. Banks are currently required to hold a high level of kuna reserves remunerated at below-market rates. ${ }^{35}$ To alleviate the resulting burden on banks, reserve remuneration could be raised to near market rates and kuna requirements reduced as macroeconomic conditions allowed. ${ }^{36}$ Second, the next stages of the reform of the payment system will be implemented, making the clearing house for interbank payments fully operational and phasing out ZAP, the payment agency through which all local currency payments and receipts between legal persons and between legal and physical persons are currently cleared ${ }^{37}$ Finally, the authorities plan to continue upgrading the regulatory and legal framework by making the adjustments warranted by experience, ensuring proper enforcement, and improving the quality of underlying statistical indicators. Having introduced a new banking law, the authorities now intend to draft a revised central bank law. To continue improving the

Since the commitments and liabilities of the BRA are guaranteed by the state, any shortfall in the funds needed for the payout of insured deposits would eventually be covered through taxation or general government borrowing.

${ }^{33}$ The BRA is legally forbidden from investing in foreign assets. A depreciation increases its contingent liabilities because a large share of insured deposits is denominated in foreign currency but would be repaid in local currency.

${ }^{34}$ Currently, banks finance deposit insurance by paying quarterly contributions to the BRA amounting to 0.2 percent of insured deposits. The price of insurance, therefore, is independent of the soundness of banks' balance sheets.

${ }^{35}$ In November 1999, the yield on statutory reserve deposits was 5.9 percent while the yield on one-month CNB bills was 10.5 percent. At 30.5 percent, the level of kuna reserve requirements is high by international standards. Since the beginning of 1999 , however, all obligatory reserves have been remunerated with the exception of reserves held as cash-invault.

${ }^{36}$ Reliance on open market operations could be increased in parallel.

${ }^{37}$ The existence of ZAP, an institution separate from the central bank, is an historical legacy of the payment system in the former SFRY. 
monitoring of banks' financial conditions, the authorities also plan to adopt the regulation for on-site supervisory inspections, implement their plan for the institutional development of the CNB supervision department, and develop an "early warning" system of indicators based on the recently introduced system for unified reporting of prudential and analytical data.

\section{Other Financial Markets}

60. Commercial banks are by far the most important players in the Croatian financial system. If money and capital markets were broadened and deepened pari passu with the development of banks, the pricing and supply of financial services would be improved greatly. For the time being, however, the nonbanking segment remains relatively small. The insurance sector is underdeveloped, although expanding rapidly. The money market discharges its role reasonably well but is highly segmented. The capital market is still in its infancy, with little demand for a scarcely diversified portfolio of financial instruments, very thin secondary markets, and a largely untested regulatory regime. This section analyzes each of these markets in turn.

\section{The insurance market}

61. The insurance sector has been expanding at a rapid pace since 1991. Annual growth rates, in fact, have averaged around 10 percent, with the life insurance segment growing even faster as the public readily caught on to a previously nonexistent product. ${ }^{38}$ At the end of 1998, 24 insurance companies operated in Croatia: four were majority-owned by foreigners and only two, Croatia Osiguranje (CO) and its subsidiary Croatia Lloyd (a reinsurance company), were state-owned. These two companies, however, dominate both the insurance and the reinsurance sector. $\mathrm{CO}$ accounted for more than 60 percent of total insurance premia at end-1998 and Croatia Lloyd was the sole national provider of reinsurance services. In spite of these companies' dominant position, however, competitive conditions are relatively good. Foreign-owned companies incorporated in Croatia are able to compete on a level playing field and the above-average growth of $\mathrm{CO}$ competitors has caused a decline in its market share. The market, however, is still very concentrated, with no insurance company other than CO holding a market share above 5 percent.

62. Due to two parallel developments, further restructuring and increased foreign participation are likely in the near future. First, both $\mathrm{CO}$ and its reinsurance subsidiary are close to being privatized. ${ }^{39}$ Preparations for sale are advanced and a deal is expected in the first half of 2000 . Second, a new insurance act providing for further liberalization and stricter supervisory requirements is close to parliamentary approval. The draft act envisages allowing foreign companies to open branches outside Zagreb, thus further increasing competitive pressures; introducing higher minimum capital requirements to strengthen balance sheets;

${ }^{38}$ It is estimated that roughly 5 percent of the population now holds life-insurance policies.

${ }^{39}$ The state, however, will retain a blocking minority stake in view of the high market share of each of the two companies. 
and forbidding insurance companies to lend to other companies while allowing them to invest in foreign assets, thus compelling insurance companies to focus on their core business while granting them access to a more diversified supply of long-term assets. Once approved, the new legislation is likely to trigger a process of consolidation. Since this would significantly test the existing regulatory framework for the first time, ${ }^{40}$ the government is planning to strengthen the supervisory agency by increasing and training its staff.

\section{The money market}

63. The Croatian money market has developed impressively although significant limitations persist. The Zagreb Money Market (ZMM) was set up in 1990 as an independent joint-stock company ${ }^{41}$ operating under the Money and Capital Market Law and its own Articles of Association. During the day, the ZMM acts as a broker for interbank transactions, charging a fee for every deal. The market is, however, thin and information is limited, leading to a relatively high dispersion of interest rates. At the end of the business day (i.e., at noon), the ZMM calculates a weighted average money market rate that is reported to the $\mathrm{CNB}$ and becomes the starting rate on the next working day.

64. Market thinness is heightened by the reluctance of the financially stronger banks to deal with the weaker ones, even in the presence of a sufficient amount of collateral. As a result, resource-surplus banks prefer to hold excess reserves with the CNB or to lend funds on the so-called bilateral interbank market. This is a separate segment of the money market instituted by the stronger banks through direct bilateral contacts that bypass the ZMM altogether. ${ }^{42}$ Given the different nature of market participants, interest rates on the bilateral interbank market are typically lower than those on the ZMM segment. As the banking crisis unfolded in mid-1998, a number of banks withdrew from the ZMM, causing rates to rise from 11 to 18 percent (Figure 7) and heightening the liquidity problems faced by the weaker banks. After the exit of the bankrupt banks in April 1999, rates on the ZMM fell, but were still reported to be some 1.5 percentage points higher than rates on the bilateral market in November 1999.

${ }^{40}$ The system, in fact, has been largely untested so far. For the time being, however, the supervision and regulation exercised by the Ministry of Finance appear adequate in ensuring the soundness of the Croatian insurance companies.

${ }^{41}$ It was then owned by 27 banks and 2 insurance companies.

${ }^{42}$ In addition to the two segments of the daily market, the ZMM operates an overnight market after the closing hours of the payment agency, ZAP. The ZMM is the sole broker that has access to information about banks' end-of-day reserve positions and has the authority to transfer the balances of banks in surplus to banks with a negative net position. Overnight loans are collateralized by borrowing banks' required reserves. Since July 1998, the overnight rate is set equal to the average day rate. 
Figure 7.Croatia: Money Market and Discount Rates, 1995-99

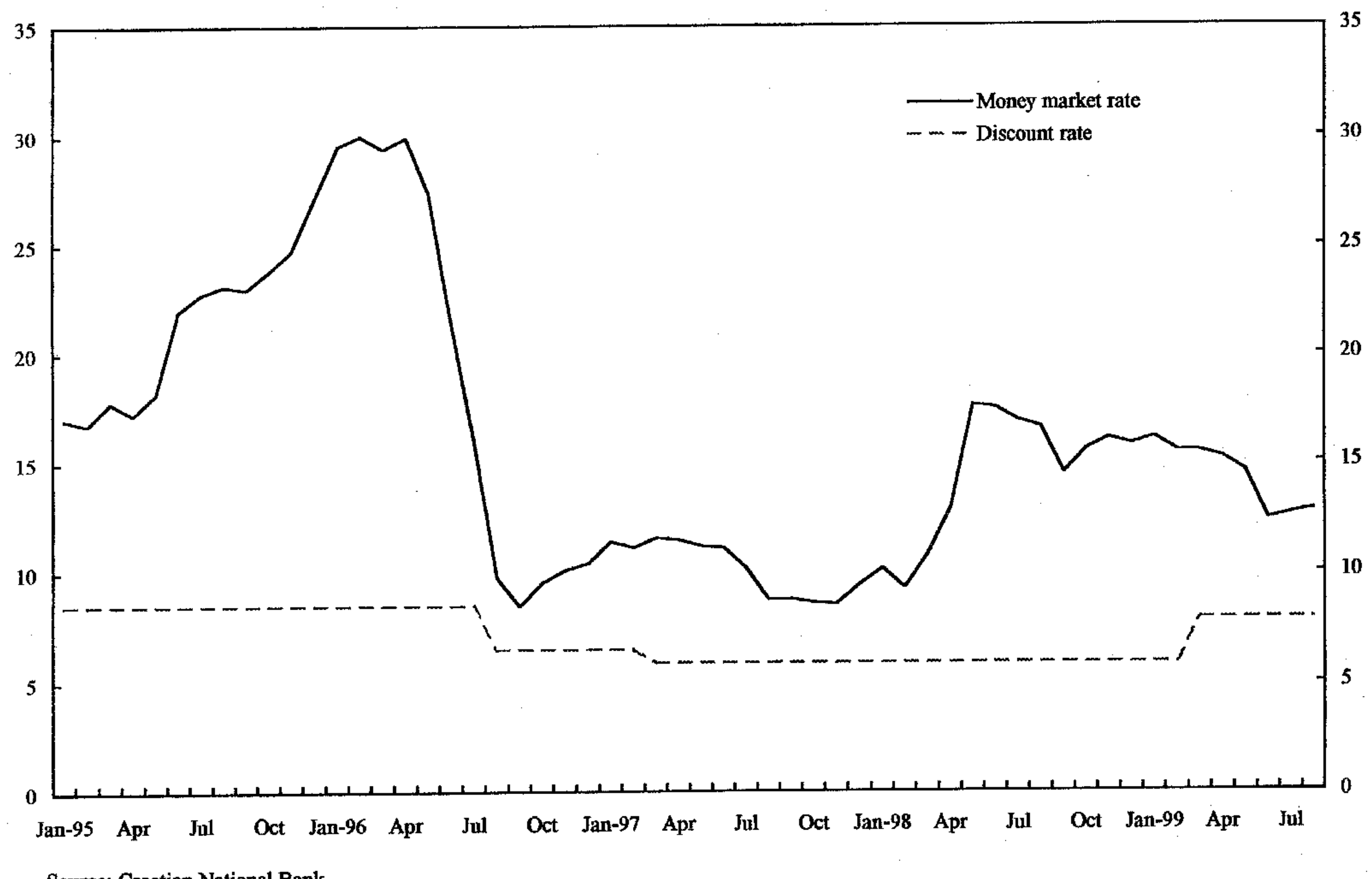

Source: Croatian National Bank. 
65. The segmented nature of the money market in Croatia has several implications:

- As there is no single interest rate indicating prevailing monetary conditions, assessing and implementing monetary policy is particularly difficult.

- There is an over-reliance on the CNB as a lender of first resort: roughly half of total liquidity borrowing by commercial banks is provided by the central bank. To reduce the excessive use of CNB liquidity facilities, the differential between the CNB's lending rates and the interbank market rates could be increased.

- Overnight transactions on the ZMM money market are predominantly among weaker banks.

66. Two ongoing developments are likely to reduce market segmentation. First, the resolution of the current banking problems and the gradual strengthening of banks will weaken its underlying causes. Second, the reform of the interbank payment system being implemented should improve the information banks can rely upon for managing their intraday liquidity and reduce transaction costs. Further improvements could also be achieved by abolishing the monopoly position enjoyed by the ZMM in brokering transactions. The presence of several brokers would generate more information and allow a more efficient determination of the interbank interest rate.

\section{The equity market}

67. The equity market in Croatia is quite rudimentary. In 1999, only six companies were listed on the official market, and 56 on the OTC market. ${ }^{43}$ Market development was stunted by the worsening domestic macroeconomic environment and by the weakening of international investors' sentiment towards emerging markets. As a result, share prices declined sharply and the CROBEX index nearly halved between end-1997 and November 1999 (Figure 8). In the first nine months of 1999, average daily turnover dropped from HrK 10.4 million in 1997 to $\mathrm{HrK} 2.4$ million and the average number of daily trades fell from 96 to 36 .

68. Even if short-term factors account for much of the current slump, the key problems facing the equity market are of a long-term nature. On the supply side, there is no incentive for closely held, private limited companies to be publicly traded. On the demand side, the share-holding habit has not yet developed, even in the presence of a favorable tax regime, ${ }^{44}$ largely because the process of privatization failed to play a catalytic role. This function, however, could be assumed by the reform of the pension system, which will lead to an increase in the demand of local institutional investors for domestic shares and bonds.

${ }^{43}$ These data refer to the Zagreb Stock Exchange but an important regional OTC market also exists in the city of Varaždin.

44 There is no stamp duty and no tax on capital gains or dividends. 
Figure 8. Croatia: Crobex Index, 1997-99

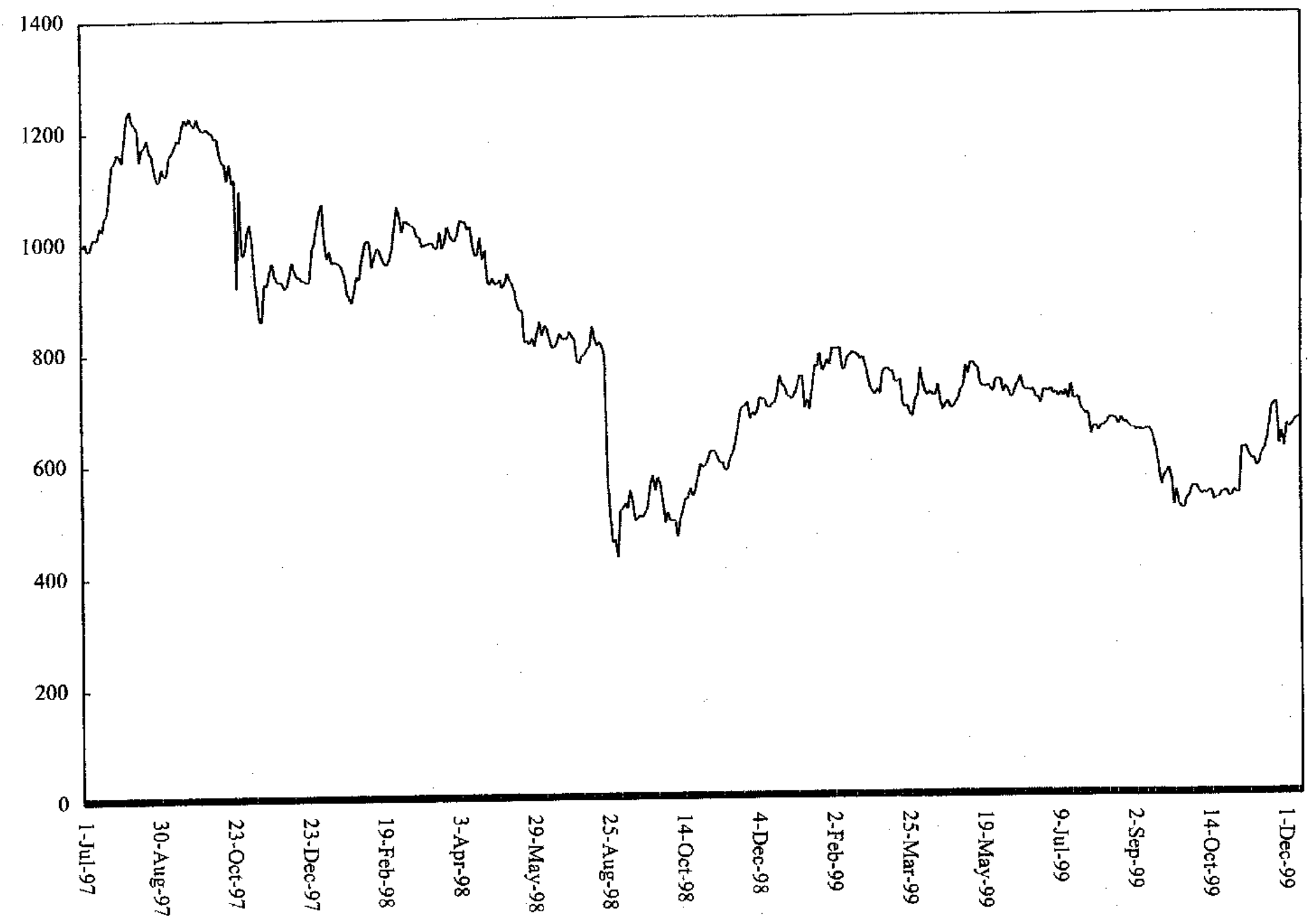

Source: Zagreb Stock Exchange: 
69. The establishment of the institutional infrastructure and regulatory framework is well advanced. There is, however, room for further improvement. The lack of reliable financial information on companies, for instance, is a major obstacle to the public trading of shares. Accordingly, the Ministry of Finance should consider re-examining the Company Law with a view to strengthening the relevant provisions (auditing standards, information disclosure, and the like). Also, the imminent creation of a central depository agency for registering share transfers will reduce the costs of transactions ${ }^{45}$ and make them more secure thanks to the establishment of a guarantee fund against default risk. The legal authority of the market regulatory body ${ }^{46}$ has recently been strengthened, along with its capacity to monitor transactions and impose sizable penalties for improper market behavior. However, the Securities Law does not provide sufficient safeguards to prevent outside auditors from approving inaccurate company financial statements. To this end, the law could be amended, for instance by authorizing CROSEC to impose fines proportional to the losses incurred as a result of audited balance sheets.

\section{The government securities market}

70. The fixed-income securities market has been expanding but does not yet constitute a significant source of financing for the government and the enterprise sector. The main instruments traded are central government Treasury bills and CNB bills. ${ }^{47}$ Market participation is mainly limited to banks and, to a smaller extent, insurance companies. Contrary to earlier practice, auctions now take place on a regular schedule and bills' maturities are not changed frequently. These developments have helped the market grow but secondary trading remains very limited and liquidity is only ensured by the transactions between banks and the CNB. A stronger secondary market, however, may emerge as a result of the imminent establishment of the central depository agency and the reform of the payment system. $^{48}$

\section{Conclusions}

71. The development of the Croatian financial sector has faced many of the difficulties experienced by other transition countries. Recent troubles have exacted a significant

\footnotetext{
${ }^{45}$ A standardized procedure for recording the net positions of buyers and sellers will substitute the current arrangement which requires the transfer of shares through manual trade-for-trade entries between counterparty brokers. This is a cumbersome procedure which does not always guarantee the timely settlement of transactions.

${ }^{46}$ The Croatian Securities and Exchange Commission (CROSEC).

${ }^{47}$ Both can be denominated in either domestic or foreign currencies. The amount of other traded government paper is not large.

${ }^{48}$ In this context, the recent introduction of a real-time gross settlement system is a particularly positive factor.
} 
macroeconomic price but the strategy implemented by the CNB since the approval of the new banking law promises the early resolution of the more immediate problems. A strengthened regulatory environment and the growing presence of foreign investors are further promising developments. However, some of the weaknesses which contributed to the recent problems are still present. To enhance the prospects for an orderly long-term development of the banking sector, the authorities intend to advance structural reforms. Sector-specific measures, however, are not enough since healthy banking sector development depends on sustainable growth in the rest of the economy. Thus, a more balanced macroeconomic policy mix is needed along with the re-launching of reforms in the real sector. Although banks dominate the Croatian financial sector, the development of other financial markets should not be allowed to lag behind. To this end, appropriate supervision needs to be provided and competitive conditions ensured. 
Table 11. Croatia: Banking System by Ownership, 1996-99

(End period; percentage of total)

\begin{tabular}{|c|c|c|c|c|}
\hline & 1996 & 1997 & 1998 & $19991 /$ \\
\hline & \multicolumn{4}{|c|}{ Assets } \\
\hline State banks & 39.5 & 32.7 & 37.0 & 40.8 \\
\hline Private banks & 60.5 & 67.3 & 63.0 & 59.2 \\
\hline Significant public stake $2 /$ & 38.9 & 9.2 & 6.1 & 6.0 \\
\hline Minor public participation & 17.1 & 47.3 & 38.4 & 38.5 \\
\hline Majority foreign-owned & 1.0 & 4.0 & 6.7 & 8.9 \\
\hline Other & 3.6 & 6.8 & 11.9 & 5.7 \\
\hline \multirow[t]{2}{*}{ Total } & 100 & 100 & 100 & 100 \\
\hline & \multicolumn{4}{|c|}{ Deposits } \\
\hline State banks & 35.3 & 29.9 & 35.3 & $\ldots$ \\
\hline Private banks & 64.7 & 70.1 & 64.7 & $\cdots$ \\
\hline Significant public stake $2 /$ & 42.2 & 8.9 & 5.4 & $\ldots$ \\
\hline Minor public participation & 19.2 & 50.6 & 42.4 & $\ldots$ \\
\hline Majority foreign-owned & 0.7 & 3.6 & 4.8 & $\ldots$ \\
\hline Other & 2.7 & 7.0 & 12.0 & $\ldots$ \\
\hline \multirow[t]{2}{*}{ Total } & 100 & 100 & 100 & $\cdots$ \\
\hline & \multicolumn{4}{|c|}{ Regulatory capital } \\
\hline State banks & 31.4 & 26.3 & 36.4 & 36.0 \\
\hline Private banks & 68.6 & 73.7 & 63.6 & 64.0 \\
\hline Significant public stake $2 /$ & 35.9 & 10.1 & 9.2 & 8.4 \\
\hline Minor public participation & 19.1 & 43.5 & 33.9 & 34.7 \\
\hline Majority foreign-owned & 3.2 & 7.7 & 13.8 & 15.3 \\
\hline Other & 10.5 & 12.4 & 6.7 & 5.6 \\
\hline Total & 100 & 100 & 100 & 100 \\
\hline
\end{tabular}

Source: Croatian National Bank.

1/ End-June.

2/ Public shareholding exceeding 20 percent. 
Table 12. Croatia: Banking Sector Assets and Liabilities, 1994-99

(End of period, percent of GDP)

\begin{tabular}{|c|c|c|c|c|c|c|c|c|c|c|c|}
\hline & \multirow[t]{2}{*}{1994} & \multirow[t]{2}{*}{1995} & \multirow[t]{2}{*}{1996} & \multirow[t]{2}{*}{1997} & \multicolumn{4}{|c|}{1998} & \multicolumn{3}{|c|}{1999} \\
\hline & & & & & Mar. & Jun. & Sep. & Dec. & Mar. & Jun. & Sep. \\
\hline Total banking sector assets & 62.5 & 63.7 & 62.5 & 68.9 & 64.0 & 65.7 & 67.3 & 67.4 & 67.4 & 63.3 & 66.6 \\
\hline Deposits & 16.9 & 21.5 & 29.8 & 36.6 & 34.0 & 35.1 & 37.0 & 37.2 & 36.2 & 33.5 & 34.7 \\
\hline Of which : Foreign currency & 10.0 & 14.3 & 20.2 & 25.3 & 24.2 & 25.3 & 26.8 & 27.4 & 27.6 & 24.6 & 25.3 \\
\hline Loans & 26.3 & 28.7 & 27.9 & 36.6 & 35.5 & 37.8 & 39.2 & 40.8 & 40.1 & 36.1 & 38.7 \\
\hline Of which: To enterprises & 21.2 & 22.9 & 21.4 & 25.3 & 24.0 & 25.1 & 25.6 & 26.5 & 25.7 & 21.7 & 23.7 \\
\hline To households & 4.0 & 4.8 & 6.1 & 10.3 & 10.3 & 11.3 & 12.2 & 12.8 & 13.0 & 12.7 & 13.3 \\
\hline \multicolumn{12}{|l|}{ Menjorandum items: } \\
\hline $\begin{array}{l}\text { GDP (HrK million) } \\
\text { Year-on-year inflation rate }\end{array}$ & -3.0 & 3.7 & 3.5 & 3.8 & 5.7 & 5.8 & 5.8 & 5.4 & 3.6 & 3.8 & 5.1 \\
\hline Loans-over-deposit ratio & 1.55 & 1.34 & 0.94 & 1.00 & 1.04 & 1.08 & 1.06 & 1.10 & 1.11 & 1.08 & 1.11 \\
\hline
\end{tabular}

Source: Croatian National Bank. 
Table 13. Croatia: Quality of Banks' Loan Portfolio, 1994-98

(In percent, end of period)

\begin{tabular}{|c|c|c|c|c|c|}
\hline & 1994 & 1995 & 1996 & 1997 & 1998 \\
\hline \multicolumn{6}{|l|}{ Risk classification } \\
\hline $\mathbf{A}$ & 87.3 & 86.8 & 88.7 & 89.0 & 84.2 \\
\hline B & 3.8 & 5.6 & 4.1 & 5.3 & 5.3 \\
\hline $\mathrm{C}$ & 4.2 & 4.2 & 4.2 & 3.1 & 4.2 \\
\hline D & 2.8 & 1.8 & 1.7 & 0.9 & 1.9 \\
\hline $\mathrm{E}$ & 1.9 & 1.6 & 1.3 & 1.7 & 4.4 \\
\hline Total & 100 & 100 & 100 & 100 & 100 \\
\hline $\begin{array}{c}\text { Of which: Nonperforming loans } \\
\text { (Categories C-E) }\end{array}$ & 8.9 & 7.6 & 7.2 & 5.7 & 10.5 \\
\hline
\end{tabular}

Source: Croatian National Bank., 


\section{EXTERNAL VULNERABILITY ANALYSIS ${ }^{1}$}

\section{A. Introduction}

72. Croatia's macroeconomic performance in the mid-1990s surpassed that of many other regional economies. During 1993-97, growth was robust, inflation remained subdued, the government deficit was contained, and the ratios of external debt to GDP and debt service to exports remained well below the average of other transition economies in Central and Eastern Europe. More recently, however, large current account deficits and the shift of their financing from nondebt creating flows to external borrowing have led to a sharp increase in the external debt ratios. In particular, the external debt to GDP ratio doubled between end1995 and mid-1999.

73. This chapter attempts to assess the vulnerability of the Croatian economy to balance of payments and financial crisis. It looks in particular at a range of indicators on which attention has increasingly focused for emerging market economies since the Asian financial crisis, comparing the Croatian economy with comparable transition countries in Central and Eastern Europe. In addition, some indicators of market perception are also presented.

\section{B. External Vulnerability Indicators}

74. With the series of major economic shocks that have affected emerging market economies over the last five years, including the "tequila" crisis of late 1994, the Asian crisis that began in 1997, and the Russia crisis in 1998, attention has increasingly focused on how to assess the risk of liquidity crisis in these economies. Several studies looked at the extent to which the depth and incidence of crises reflect solvency related fundamentals, and whether and to what extent they reflect a lack of liquidity. ${ }^{2}$ These studies tried to establish the relevance of key variables in providing early indications of currency crises.

75. Indicators that appeared to be particularly useful in that context include the current account deficit, export growth, the deviation of the real exchange rate from trend, the ratios of short-term debt and broad money to gross international reserves, and the change in reserves. The first three (current account deficit, export growth and deviations of the real exchange rate) are indicators of solvency: low current account deficits lead to lower needs for external borrowing, high export growth ensures that future debt service as a percent of external revenue is smaller for a given current account deficit, and changes in real exchange rates affect the future path of the current account deficit. The other three are liquidity indicators: the ratio of short-term debt (on a remaining maturity basis) to reserves indicates the ability of a country to service its debt falling due over the coming year if the country is

\footnotetext{
${ }^{1}$ Prepared by Joël Toujas-Bernaté. This chapter has benefited from inputs provided by Gary O'Callaghan.

${ }^{2}$ Such studies include Sachs, Tornell and Velasco (1996), Frankel and Rose (1996), Kaminsky, Lizondo and Reinhart (1998), and Bussière and Mulder (1999).
} 
cut off from external financing, the ratio of broad money to reserves captures the potential for capital flight by residents, while the change in reserves is an indicator of the residual influences on the balance of payments.

76. IMF staff has developed an Early Warning System based on such a set of indicators meant to allow for a long-range alert of the external vulnerability of countries. Particular efforts have also been made to improve the analysis of liquidity issues per se, and in particular of the adequacy of international reserves. The traditional measure comparing reserves to imports does not provide an indication of the ability of reserves to buffer against capital market shocks. Thus, attention has shifted to the ratio of reserves to short-term debt, where short-term debt is defined on a remaining maturity basis. Empirical work suggests that this ratio is indeed a reasonably good predictor of the incidence and depth of crises, even if no single measure can capture all dimensions of vulnerability.

77. Attempts have been made to find simple benchmarks that a country should satisfy in order to minimize vulnerability. An appealing benchmark of "one" for the ratio of reserves to economy-wide short-term debt has received some empirical support. Bussière and Mulder (1999), for instance, found that a ratio of at least one, even with a modest current account deficit and a slightly appreciated exchange rate, would ensure that the risk of a crisis remains low. As another benchmark, it has been suggested that countries should manage their external assets and liabilities in such a way as to be able to live without foreign borrowing for up to one year. This so-called Guidotti rule would require countries to hold reserves not only to cover liabilities maturing within a year, but in addition reserves sufficient to cover one year's current account deficit. A modified Guidotti rule, which has also received attention, consists of adding net FDI to the current account deficit.

78. In looking at measures of liquidity, an important issue is the exact definition of the concepts of reserves and short-term debt. In particular, all forward liabilities should be recognized as such, and debt with embedded put options should be taken to be payable on the earliest date when the creditor can demand repayment. Also, any part of the reserves pledged or used as collateral should be excluded from the concept of usable reserves, as such reserves prove not to be readily available in time of financial crisis.

\section{External Vulnerability of Croatia}

79. In the mid-1990s, following a successful stabilization program initiated at end-1993, the external position of the Croatian economy looked fairly robust (Table 14): the current account balance averaged a surplus of 1.2 percent of GDP in 1993-95; the real exchange rate had stabilized; the ratio of external debt, mostly inherited from the former Socialist Federal Republic of Yugoslavia (SFRY), to GDP was very low at about 20 percent; the international reserves position was relatively comfortable, with a ratio of short-term debt (on a remaining maturity basis) to official gross reserves of about one third in 1995 and net international reserves equivalent to more than 2 months of imports of goods and non-factor services. Only the very modest growth in exports and a strong expansion of bank credit to the private sector during the three preceding years suggested some caution. 
80. In 1995-96, Croatia made rapid progress in normalizing its external relations by concluding debt rescheduling agreements with the Paris Club and the London Club. Reflecting Croatia's sound debt and reserve positions, and favorable external prospects, three credit agencies awarded Croatia an investment grade sovereign credit rating in early 1997, putting Croatia among other transition economies such as Poland and Hungary. ${ }^{3}$ This allowed Croatia to rapidly gain access to capital markets, and shift away from short-term inflows to medium- and long-term borrowing. In particular, Croatia issued three eurobonds of US $\$ 300$ million, DM 300 million and ATS 700 million, respectively, in 1997, and one eurobond (so-called "Matador" bond) of Ptas 15 billion in 1998 . $^{4}$

81. Much larger current account deficits in 1997 and 1998, reaching the equivalent of 11.6 percent and 7.1 percent of GDP, respectively, were largely financed through new external borrowing, thanks to the newly gained access to capital markets. This contributed to a substantial increase in the stock of external debt, which reached the equivalent of about 37 percent of GDP at end-1998, out of which public and publicly guaranteed debt was equivalent to about 20 percent of GDP. ${ }^{5}$ Thus, at end-1998, several indicators of solvency were showing signs of growing weakness: the current account deficit averaged 8.2 percent during the three preceding years; the external debt to GDP ratio nearly doubled-albeit from a low base-in 3 years; and the growth in exports remained very modest.

82. Regarding the indicators of liquidity position, net international reserves increased by about US $\$ 900$ million between end-1995 and end-1998, to reach the equivalent of 2.9 months of imports of goods and nonfactor services. While the stock of short-term debt (on a remaining maturity basis) increased somewhat during 1995-98, its ratio to gross reserves was still relatively low at about 37 percent at end-1998. The indicator based on the modified Guidotti rule, namely the ratio of short-term debt corrected for the current account deficit net of foreign direct investment to reserves, was less favorable at about 62 percent at end-1998, after decreasing from a peak of about 119 percent at end-1997. Finally, the ratio of broad money to reserves increased steadily between end-1995 and end-1998 from 2.4 to 3.2 , with about two-thirds of broad money in the form of foreign currency deposits. This

\footnotetext{
${ }^{3}$ Moody's, Standard \& Poor's, and IBCA gave Croatia in January 1997 their lowest investment grade rating for long-term foreign currency bonds and higher ratings for shortterm bonds (both in foreign currency and kuna). Uncertainties about the political process and the possible fiscal implications of restructuring demands were cited among the main reservations.

${ }^{4}$ The Euro-dollar bond has a 5 -year maturity and a 7 percent coupon ( 80 basis point over 5-year U.S. treasury bills at the time of issuance); the Euro-DM bond has a 7-year maturity and a 6.125 percent coupon ( 95 basis points over the German government benchmark bond at the time of issuance); the Euro-ATS bond has a 5-year maturity and a 5.625 percent coupon; and the "Matador" bond has a 3 -year maturity and a 6.5 percent coupon.

${ }^{5}$ At end-1998, external government debt was estimated to be equivalent to about 15 percent of GDP, and publicly guaranteed external debt to about 5 percent of GDP.
} 
seemingly still comfortable, albeit weakening, external liquidity position should be seen, however, against the fact that part of the increase in official reserves reflected an increasing stock of foreign currency liabilities of the monetary authorities to residents. With the implementation of new regulations regarding reserve requirements on foreign currency deposits in the third quarter of 1998, domestic commercial banks began to accumulate reserve deposits in foreign exchange with the central bank from September 1998 through April 1999. The central bank also started issuing bills in foreign exchange in April 1998. The stock of these central bank foreign exchange liabilities amounted to about US\$500 million at end-1998 and US\$740 million in mid-1999.

83. A important worry from the standpoint of vulnerability in the last few years has been the emerging weakness in the banking sector. In 1998, a weak economy and a drying-up of repatriated foreign savings exposed the underlying insolvency of a rapidly growing group of private banks. The central bank had to intervene in an increasing number of banks, and public concerns about the soundness of the banking sector contributed to exchange market pressures in late 1998 and early 1999. At the same time, Croatian banks switched from a significant short position in foreign exchange at end-1997 to a long position by the third quarter of 1999. While it improved banks' direct exposure to currency depreciation, it also added to the pressures on the exchange rate during this period. Banks' indirect exposure to currency depreciation, however, likely remains substantial, given that an estimated 50 to 60 percent of banks' domestic assets are denominated in, or indexed to, foreign currency, of which a substantial proportion may be presumed to be uncovered by the borrowers. ${ }^{6}$

84. Comparing external vulnerability indicators for Croatia with those for other Central European economies confirms the view that, while the external liquidity position of Croatia still remains favorable, Croatia's position in terms of external solvency indicators is weaker. External vulnerability indicators at end-1998 were compiled for a sample of 10 other Central and Eastern European countries (see Figure 9) ${ }^{7}$ The ratios for Croatia of short-term debt and short-term debt corrected for the current account deficit net of FDI to reserves are in the median to lower range of the sample. The more traditional measure of reserves in months of imports shows Croatia's position at the average of the sample. Croatia is also one of the few countries in the sample, together with the Slovak Republic and Slovenia, not to have had an appreciation of its real exchange rate over the last four years. ${ }^{8}$ However, Croatia compares less favorably regarding the current account, growth in exports, stock of external debt and growth in banking sector credit to the private sector indicators, although it is never among the worst ranked countries of the sample.

\footnotetext{
${ }^{6}$ See Chapter II for a detailed discussion of recent developments in the banking sector.

${ }^{7}$ The sample includes Bulgaria, the Czech Republic, Estonia, Hungary, Latvia, Lithuania, Poland, Romania, the Slovak Republic, and Slovenia.

${ }^{8}$ The appreciation of the real exchange rate over the last four years for some other countries reached 40 to 80 percent. See also Chapter IV.
} 


$$
-59-
$$

Figure 9. Croatia: External Vulnerability Indicators in a Regional Perspective 1/ Liquidity Indicators

External Reserves in Months of Imports, end-1998

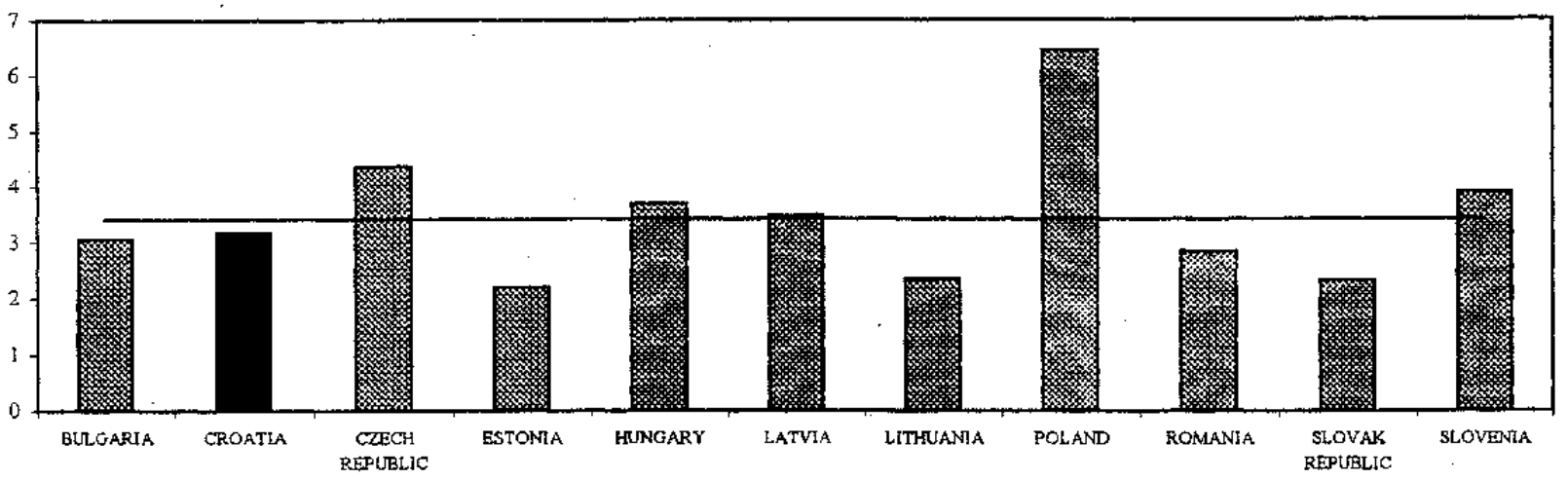

Short-Tern Debt to Reserves Ratio, end-1998 $2 /$

(in percent)

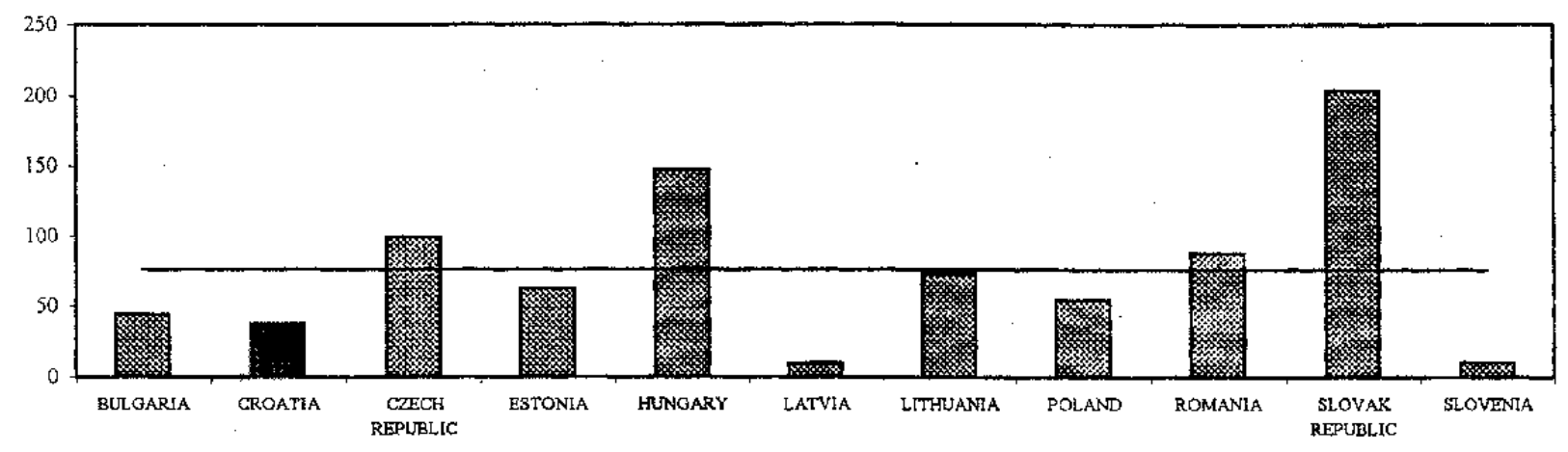

Short-Term Debt and Current Account Balance Net of FDI to Reserves Ratio, end-1998 $2 /$ (in percent)

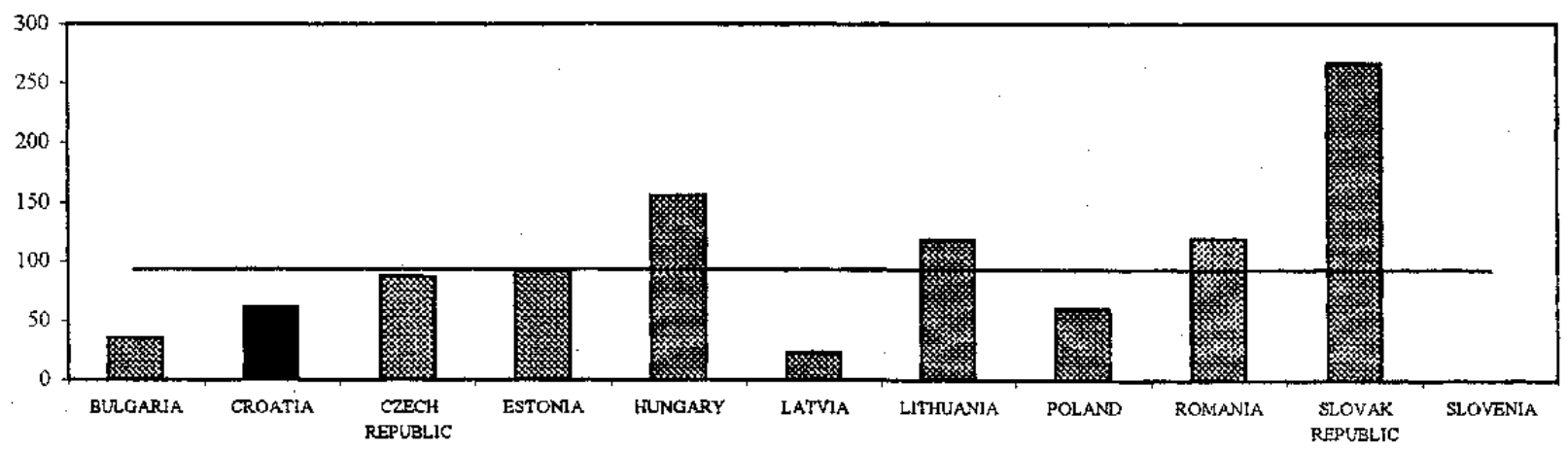

Sources: WEO database; and International Financial Statistics.

1/ In each chart, the average of the sample is represented by a line.

$2 /$ Short-term debt is on a remainig maturity basis. 
Figure 9 (continued). Croatia: External Vulnerability Indicators in a Regional Perspective 1/ Solvency Indicators

Current Account Balance to GDP Ratio

(average 1996-98, in percent)

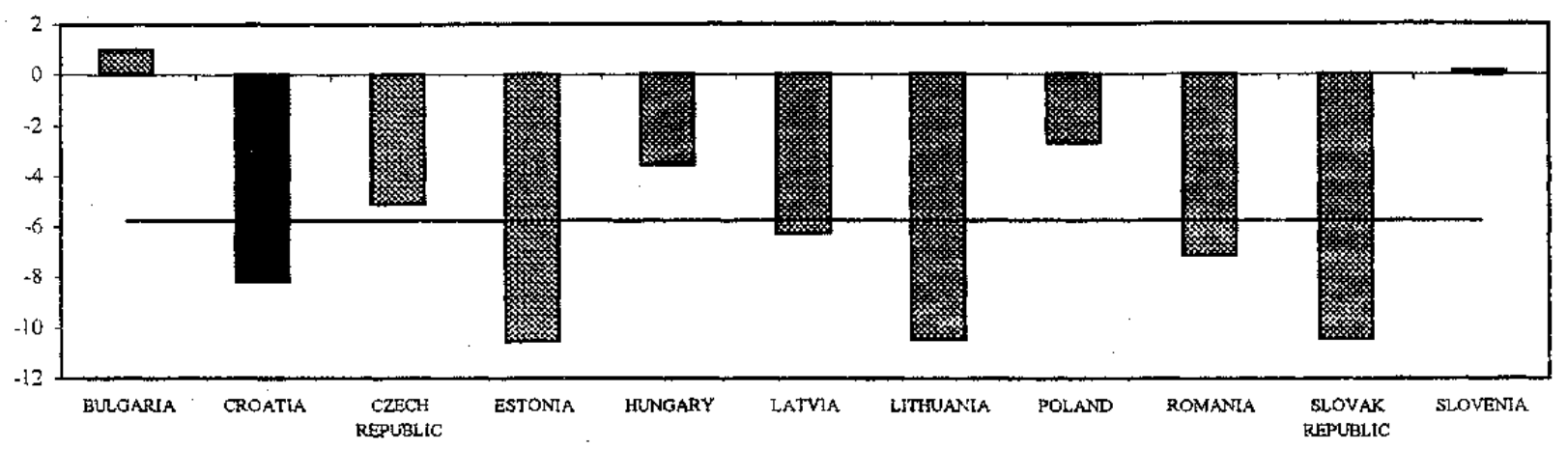

Total Externai Debt to GDP Ratio, end-1998

(in percent)

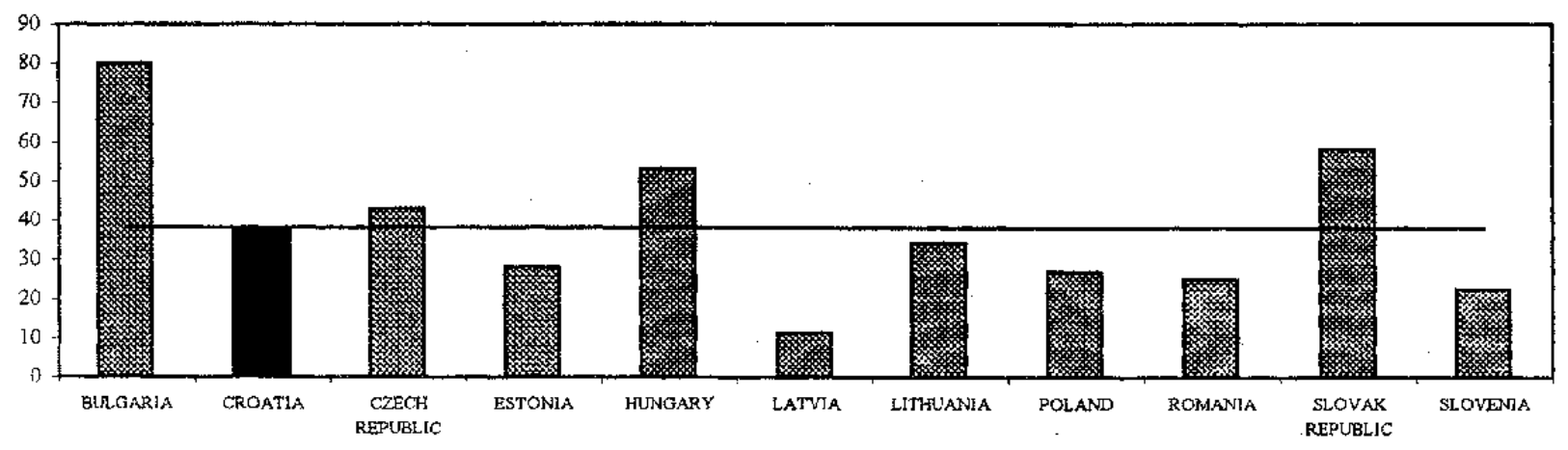

Short-Term Debt to GDP Ratio, end-1998 2/

(in percent)

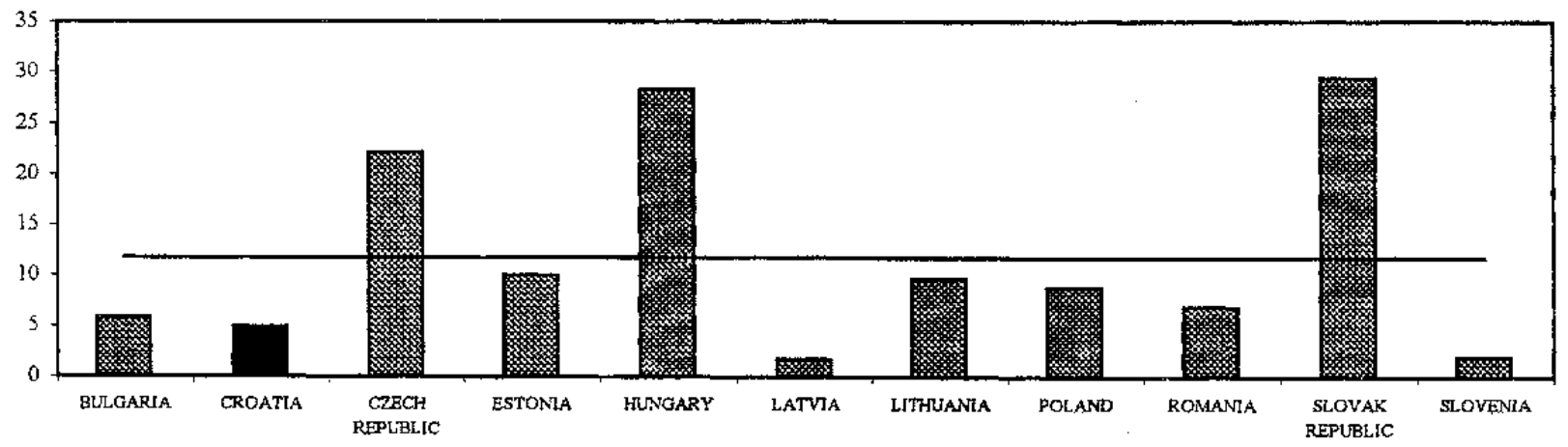

Sources: WEO database; and International Financial Statistics.

1/ In each chart, the average of the sample is represented by a line.

2/ Short-term debt is on a remaining maturity basis. 
Figure 9 (concluded) Croatia: External Vulnerability Indicators in a Regional Perspective 1/

Solvency and Other Indicators

Broad Money to Reserves Ratio, end-1998

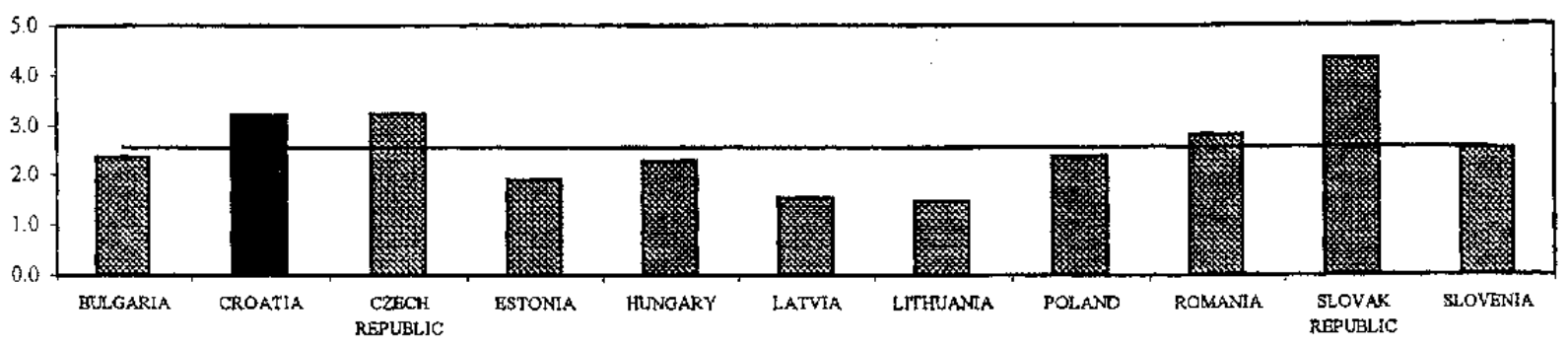

Barking Sector Credit to Private Sector

(change during 1995-98 in percent of GDP)

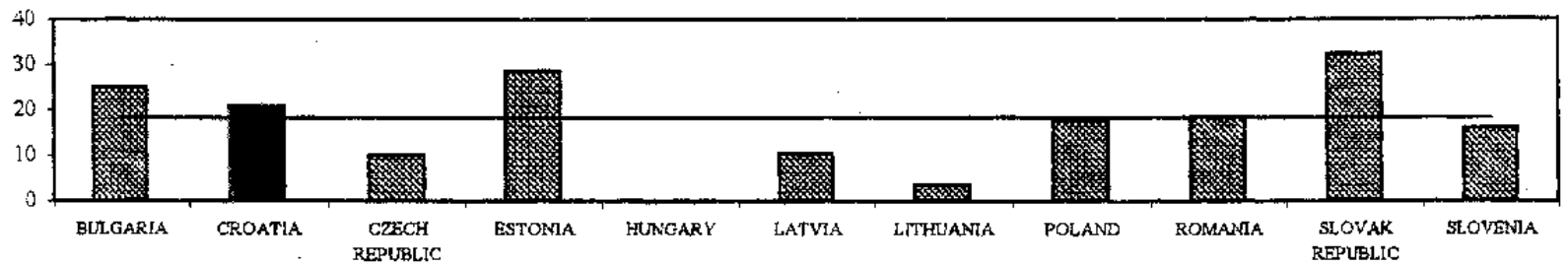

Real Effective Exchange Rate Appreciation

( $1995 \mathrm{~m} 8$ to $1999 \mathrm{~m} 8$, in percent)

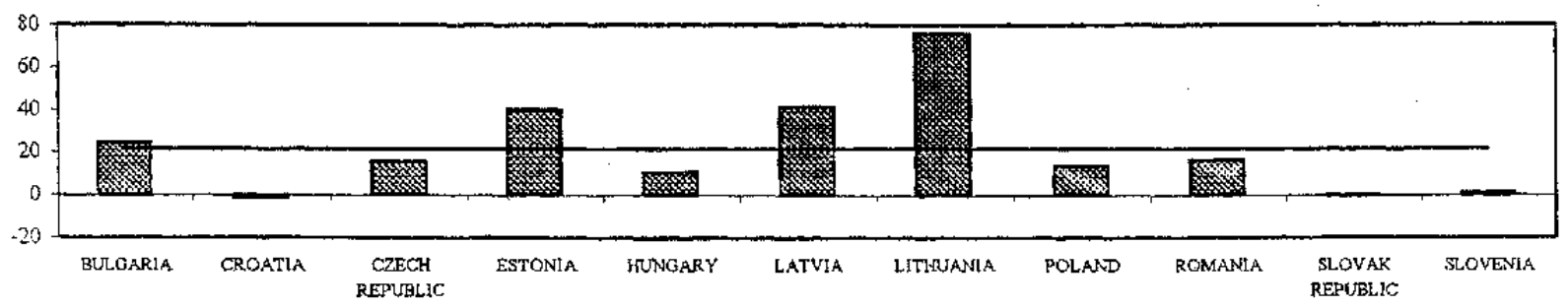

Growth in Exports of Goods and NFS in US Dollar Terms

(average 1996-98, in percent)

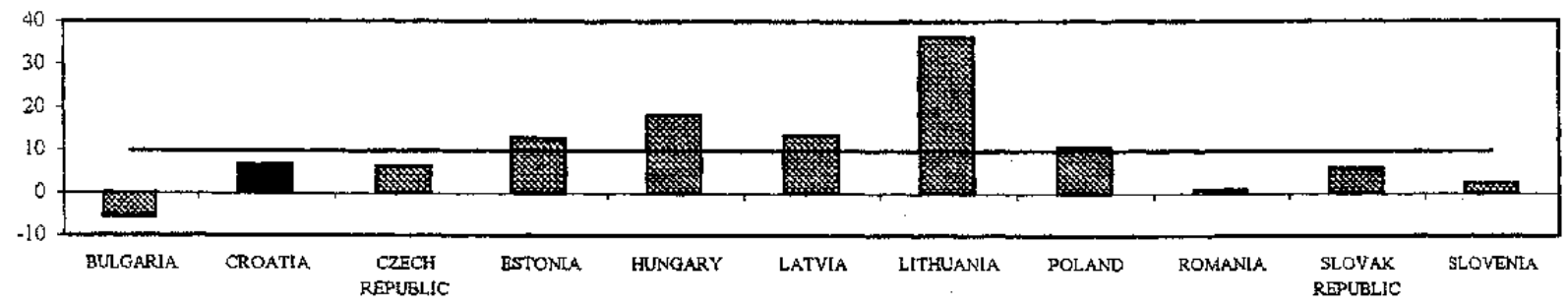

Sources: WEO database; International Financial Statistics; and Information Notice System.

$1 /$ In each chart, the average of the sample is represented by a line. 


\section{Financial Markets' Perception}

85. In the last few years, financial market participants have viewed Croatia with some concern. Following the Asian financial crisis, interest spreads on Croatia's foreign bonds increased by more than in other transition countries with a similar investment-grade credit rating. After initially trading at less than 100 basis points during the first half of 1997, the spread on Croatia's eurodollar bond, which was issued in February 1997 and will mature in 2002 , reached about 300 basis points in January 1998 (Figure 10). In the wake of the Russian crisis, the spread increased markedly, reaching more than 600 basis points in October 1998 . Since then, it has fluctuated within a range of $360-530$ basis points, which is comparable to bonds in lower investment grade rating categories. Countries with similar credit rating to Croatia, such as Malaysia, South Korea or Thailand, currently carry yields that are about 350 basis points below that on Croatian bonds.

86. During 1999, three credit-rating agencies issued negative reviews. In April, Croatia lost its investment grade rating from IBCA. This was attributed to the increased fiscal deficit and heightened pressures on the current account and banks, in the context of a halt to economic growth and general regional uncertainty surrounding the Kosovo crisis. In June, Standard \& Poor's and Moody's both switched from a stable outlook to a negative outlook on foreign currency debt, which was, however, reaffirmed at investment grade ratings. Standard \& Poor's attributed the negative outlook to the increasingly uncertain domestic political environment, and severe adjustment problems in the banking and corporate sectors, in the context of tight monetary conditions and subdued economic activity. Moody's cited large upcoming amortization payments and a lack of competitiveness as chief sources of concern.

87. The negative reviews prompted many investment firms to switch to an "underweight" recommendation to their clients, generally citing a fear of increased fiscal and current account pressures in the year 2000 , an uncertain domestic political climate, and anticipation of a possible future ratings' downgrade. On the other hand, some firms have seen the high yields on Croatian debt as offering a good investment opportunity.

88. Despite this relatively negative current perception, Croatia was able to issue its first samurai bond of $¥ 25$ billion (about US $\$ 250$ million) in early December 1999 . The amount was raised from $¥ 20$ billion initially due to strong investor demand, mainly from small- to medium-sized banks and corporations in the Tokyo area. This bond received an investment grade rating of BBB- from Standard \& Poor's, and carries a coupon of 4 percent.

89. Developments in the Zagreb stock exchange also reflected the concerns of financial market participants. The CROBEX index first fell by about 20 percent in October 1997 following the Asian financial crisis (see Figure 10). It then fell by about 50 percent between April and September 1998, following the Russian crisis, reaching an historic low on September 1, 1998, before recovering somewhat in late 1998 and early 1999. Again reflecting concerns regarding the situation of the banking and corporate sectors, as well as the uncertain political climate, the index fell by about 30 percent between mid-July and endSeptember 1999. Overall, the Zagreb Stock exchange index lost more than half of its value between August 1997 and end-September 1999. 
Figure 10. Croatia: Financial Markets Indicators, 1997-99

Bond Spread over U.S. "Treasuries"

(monthly average, in basis points)

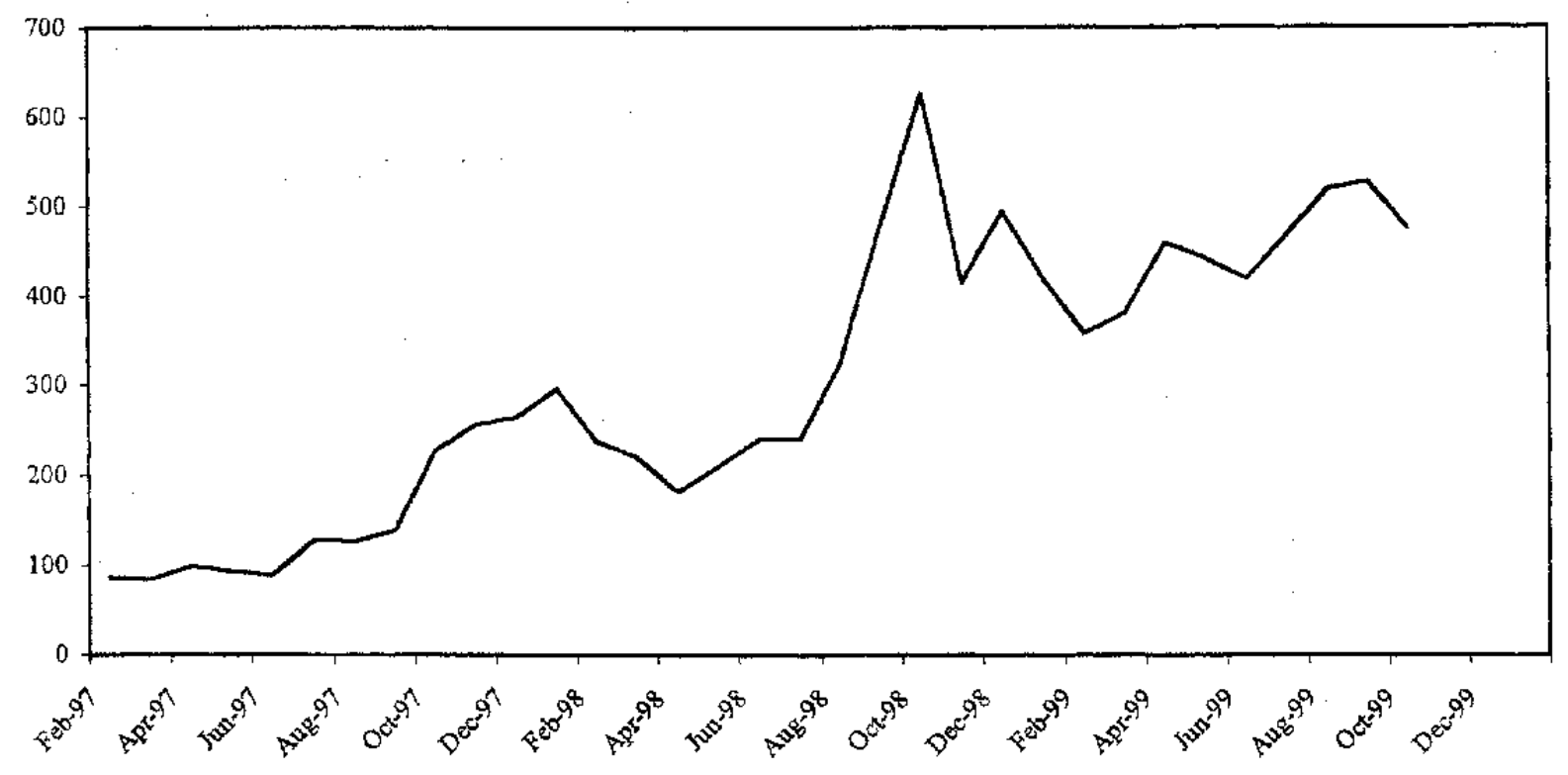

Zagreb Stock Exchange Index

(July 1, 1997=1000)

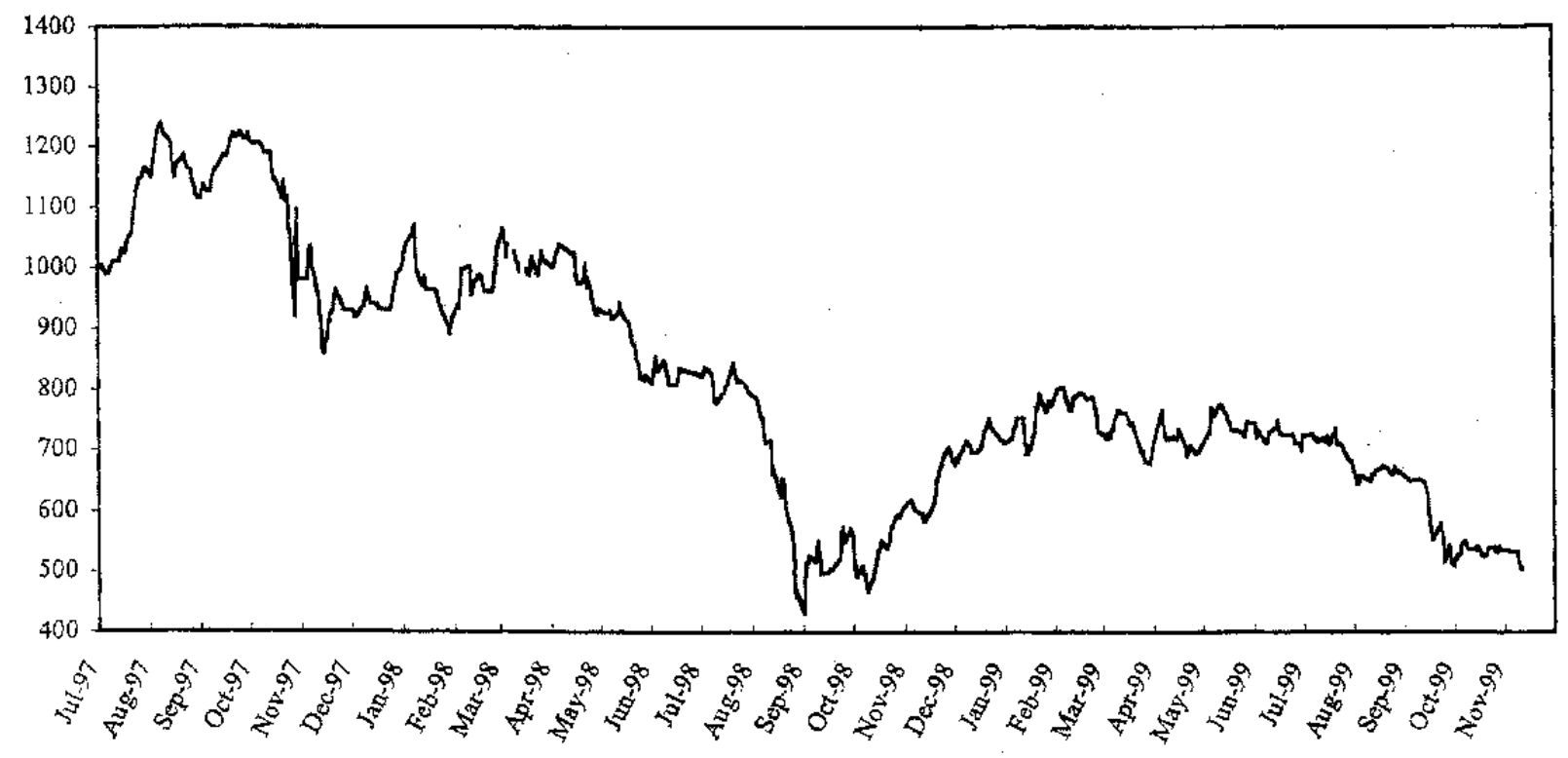

Sources: Bloomberg; and Zagreb Stock Exchange. 


\section{E. Conclusions and Prospects}

90. The external position of Croatia, which looked robust in the mid-1990s, has weakened in the last few years. In particular, several indicators of external solvency, including the current account deficit, the external debt to GDP ratio, and export growth, have shown signs of relative weakness, and do not compare favorably with some other Central and Eastern European countries. Croatia has been able, however, to maintain a comfortable external liquidity position, with international reserves more than covering the external shortterm debt on a remaining maturity basis.

91. In a medium-term scenario prepared by the IMF staff, which is underpinned by a reinvigorating of structural reforms in the enterprise sector, a downsizing of the role of the government in the economy, and increased cooperation between Croatia and its trading partners, the current account deficit is expected to gradually decrease to about $31 / 2$ percent of GDP within 5 years, while net international reserves would be boosted to the equivalent of nearly 4 months of imports and the external debt to GDP ratio reduced to 33 percent (see Table below). Croatia would thus improve its external sustainability. However, reflecting large external debt repayments falling due in 2000-01, partly linked to bullet repayments of international bonds, the short-term debt to reserves ratios would worsen in the next two years before improving again thereafter. Gross usable reserves are nevertheless projected to fully cover the external short-term debt on a remaining maturity basis over the 5-year projection horizon.

\begin{tabular}{|c|c|c|c|c|c|c|}
\hline \multicolumn{7}{|c|}{$\begin{array}{l}\text { Croatia: Medium-Term Scenario } \\
\text { (In percent of GDP, unless otherwise indicated) }\end{array}$} \\
\hline & 1999 & 2000 & 2001 & 2002 & 2003 & 2004 \\
\hline Current account balance & -6.5 & -5.0 & -4.5 & -4.0 & -3.8 & -3.6 \\
\hline Net exports of goods and nonfactor services & -8.2 & -7.2 & -6.0 & -5.5 & -4.8 & -4.1 \\
\hline External debt & 39.0 & 36.5 & 35.2 & 33.9 & 33.8 & 33.1 \\
\hline Net international reserves 1 / & 3.1 & 3.2 & 3.2 & 3.2 & 3.5 & 3.8 \\
\hline $\begin{array}{l}\text { Short-term debt in percent of gross usable } \\
\text { reserves } 2 /\end{array}$ & 88.1 & 85.0 & 94.1 & 74.0 & 64.5 & 49.2 \\
\hline $\begin{array}{l}\text { Current account deficit and short-term dcbt } \\
\text { net of FDI in percent of gross usable reserves } 2 /\end{array}$ & 83.4 & 91.7 & 100.3 & 82.1 & 70.4 & 54.5 \\
\hline
\end{tabular}




\section{References}

Bussière, Matthieu and Christian Mulder, 1999, "External Vulnerability in Emerging Market Economies: How High Liquidity Can Offset Weak Fundamentals and the Effect of Contagion", IMF Working Paper WP/99/88 (Washington: International Monetary Fund).

Frankel, Jeffrey A. and Andrew K. Rose, 1996, "Currency Crashes in Emerging Markets: an Empirical Treatment", Journal of International Economics, Vol. 41, pp.351-366.

Kaminsky, Graciela, Saul Lizondo and Carmen Reinhart, 1997, "Leading Indicators of Currency Crises", IMF Staff Papers, Vol. 45, No. 1.

Sachs, Jeffrey, Aaron Tornell and Andres Velasco, 1996, "Financial Crises in Emerging Markets: The Lessons from 1995", Brookings Papers on Economic Activity: I, Brookings Institution, pp.147-215. 
Table 14. Croatia: Selected External Vulnerability Indicators, 1995-98

(In percent, unless otherwise indicated)

Real Effective Exchange Rate Appreciation (cumulative over last 4 years)

Total External Debt to GDP Ratio (year end)

Short-Term Debt to GDP Ratio (year end) $1 /$

Short-Term Debt to Reserves Ratio (year end) 1/

Short-Term Debt and Current Account Net of FDI to Reserves Ratio (year end)1/

Broad Money to Reserves Ratio (in units)

External Reserves in Months of Imports of Goods and Non-Factor Services

Current Account Balance to GDP Ratio (3-year average)

Banking Sector Credit to Private Sector (3-year change in percent of GDP)

Growth in Exports of Goods and Nonfactor Services (3-year average)

$\begin{array}{rr}\ldots & 40.3 \\ 20.8 & 23.2 \\ 3.2 & 4.7 \\ 31.6 & 40.7 \\ 102.8 & 67.2 \\ 2.4 & 2.8 \\ 2.4 & 2.8 \\ 1.2 & -2.6 \\ 43.1 & 13.3 \\ 0.6 & 8.2\end{array}$

\section{$-0.1$}

31.9

5.8

45.6

118.7

3.1

2.7

$-8.4$

18.9

4.9

Sources: WEO database; International Financial Statistics; and Information Notice System.

V Short-term debt is on a remaining maturity basis. 


\section{Selected Aspects of EXPORT Performance, Competitiveness, AND Trade POLICY ${ }^{1}$}

\section{A. Introduction}

92. Croatia had a relatively poor export performance over 1994-98, especially when compared with a sample of the Central and Eastern European countries (CEECs). ${ }^{2}$ This chapter, after examining in more detail recent export performance, attempts to assess the extent to which Croatia's underperformance was due to a worsening in Croatia external competitiveness. It also explores the roles which could have been played by the trade regime and the trade relations between Croatia and its main partners. In the last section, recent progress towards WTO accession is described.

\section{B. Recent Export Performance}

93. In response to the collapse of the Soviet Union and the Council of Mutual Economic Assistance, the CEECs undertook profound reforms of their trade and exchange regimes. The benefits of this reform process have begun to be felt in many CEECs. Table 15 presents some export performance indicators of a sample of CEECs, including Croatia, during 1994-98. On average for the sample, both exports of goods and of goods and nonfactor services increased by more than 70 percent in U.S. dollar terms over the period. Some countries, including Estonia, Hungary, and Latvia experienced cumulative growth of above 100 percent. As a result, the share of exports of goods and nonfactor services in GDP increased by about 3 percentage points on average. In particular in Hungary, this share more than doubled from a relatively low base.

94. Most of these positive export developments in the CEECs have come from a reorientation of trade toward the EU. On average, exports from the sample of CEECs to the EU increased by more than 15 percent per year during 1994-98, with Estonia, Hungary and the Slovak Republic experiencing annual growth rates in excess of 20 percent. These impressive growth rates led to increases in the market shares of the CEECs in total EU imports from outside the EU by 25 percent on average over the period. As a result, the EU became the increasingly dominant destination of exports for the CEECs.

95. By contrast, Croatia's export developments indicate that Croatia failed to benefit from the rapid expansion of CEEC exports to the EU. The cumulative growth rates of exports of goods and nonfactor services and especially of goods over 1994-98 were much lower than

\footnotetext{
${ }^{1}$ This chapter was prepared by Joël Toujas-Bernaté.

${ }^{2}$ The sample of CEECs to which Croatia is compared in this chapter includes Bulgaria, the Czech Republic, Estonia, Hungary, Latvia, Lithuania, Poland, Romania, the Slovak Republic, and Slovenia.
} 
the average of the sample, at 20 percent and 8 percent, respectively. ${ }^{3}$ More recently, the U.S. dollar value of Croatia's exports of goods during the first 10 months of 1999 decreased by about 8 percent compared with the same period last year. ${ }^{4}$ As a result, the share of exports of goods and nonfactor services in GDP decreased over the 1994-99 period. These developments were largely due to a noticeable decrease in Croatia's exports to the EU and an associated large loss of market share in the EU. Croatia is the only country of the sample in this situation. More recently, however, Croatia has been able to maintain its share in EU imports from outside the EU, as shown in Figure 11. Since early 1998, Croatia has even experienced some gains in this market.

96. Thus, instead of being reoriented toward the EU like the other CEECs (the share of Croatia's exports to the EU in its total exports decreased over 1994-98), Croatia's exports have been increasingly oriented toward nonindustrial countries, including the successor countries of the former SFRY. In 1998, more than 25 percent of Croatian exports went to these countries, of which nearly 15 percent to Bosnia and Herzegovina. But even in these countries, Croatian exports lost market share, especially since early 1997 (see Figure 11). Also, Croatian exports to CEFTA countries have been subdued, and represented less than 15 percent of total exports in 1998 , of which about 10 percent to Slovenia. ${ }^{6}$

97. Another important aspect differentiating Croatia from the other CEECs regards the developments in the composition of exports. The composition of Croatia's exports has changed little since 1994. In particular, an index representing the changes in the composition of exports toward the EU between 1994 and 1998 (see Table 15, last column) indicates that the structure of Croatian exports has changed the least among the CEECs. ${ }^{7}$ This might reflect a slower pace of restructuring of the Croatian economy as a whole compared with other transition economies.

${ }^{3}$ Growth in the tourism sector accounted for most of the better performance of services exports.

${ }^{4}$ A decrease in exports to Bosnia and Herzegovina and Russia accounted for more than half of the decrease in total exports in the first ten months of 1999. Exports to Bosnia and Herzegovina plummeted after the cancellation of a bilateral free trade agreement with the Federation of Bosnia and Herzegovina in May 1999, while those to Russia (including pharmaceuticals and telecommunication equipment) collapsed after the Russian crisis in August 1998.

${ }^{5}$ The decrease in Croatia's exports to the EU in 1999 thus appears to be due to a decrease in total EU imports from outside the EU as economic growth in the EU was slowing down.

${ }^{6}$ CEFTA is the Central European Free Trade Agreement including the Czech Republic, Hungary, Poland, Romania, the Slovak Republic, and Slovenia.

${ }^{7}$ This index is calculated as the sum of the absolute changes in the shares in total exports for each individual SITC 3-digit category between 1994 and 1998. 
Figure 11. Croatia: Exports Market Shares, 1995-99

(Index values, $1995 \mathrm{Ql}=100$ ) $1 /$

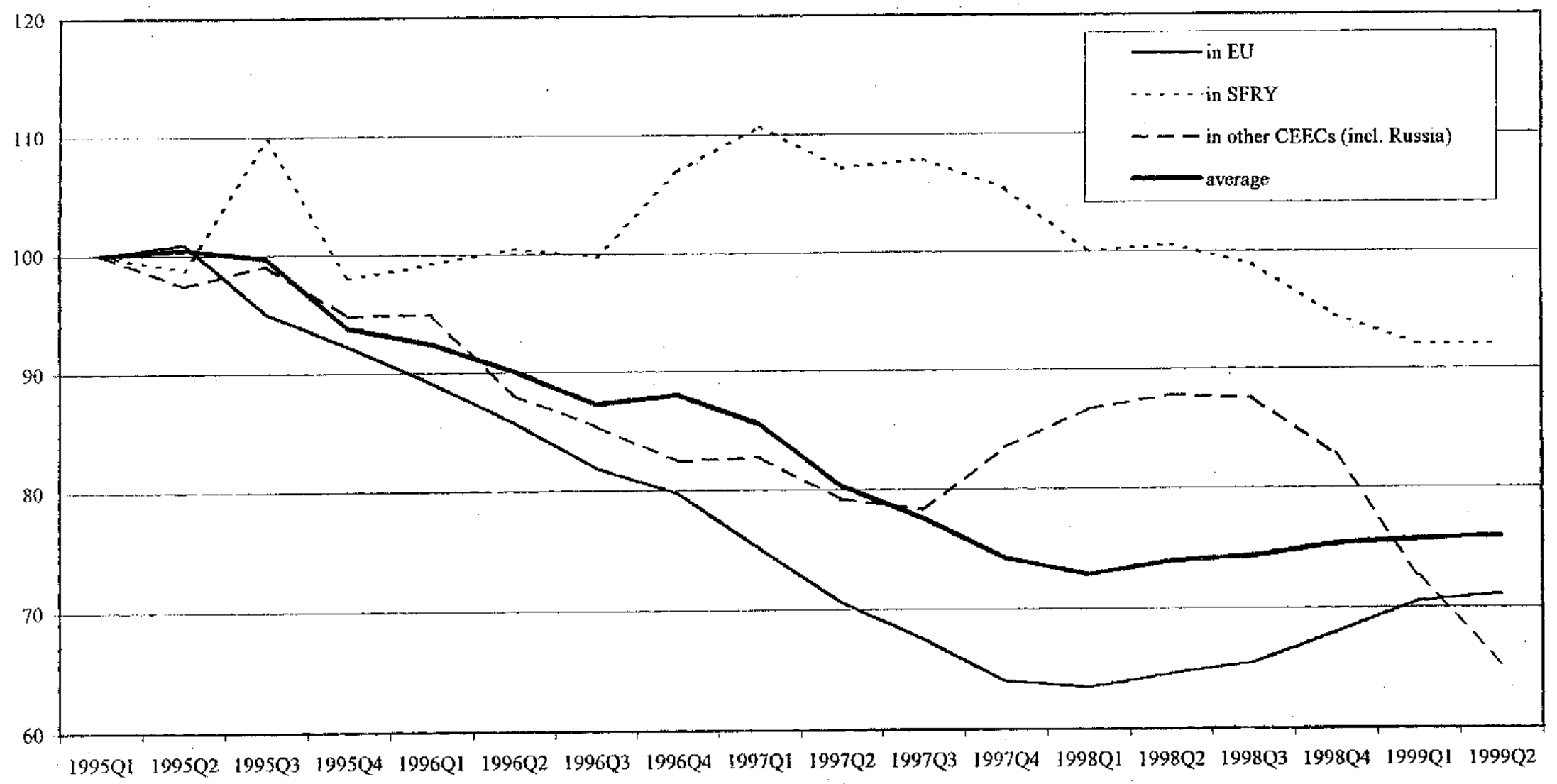

Source: Direction of Trade Statistics (DOTS) database.

1/ Index of market shares of cumulative exports over the four preceding quarters. 


\section{External Competitiveness}

98. In order to assess to what extent Croatia's relatively weak export performance can be accounted for by changes in external competitiveness, a range of competitiveness indicators are reviewed below. Price-based real effective exchange rates are the most frequently used indicators of external competitiveness. ${ }^{8}$ Among them, CPI-based real exchange rate indicators have the advantages that consumer prices are calculated using baskets of goods that are broadly similar across countries, and that such indices are readily available. Other frequently used indicators include PPI-, export price index- and ULC-based real exchange rates, as well as the relative price of nontradables to tradables.

99. All these indicators have pros and cons, and suffer from certain shortcomings as competitiveness indicators, in particular in the context of transition economies. During the transition process, significant productivity and efficiency gains are realized, and prices of some goods and services, which were strongly distorted, including through subsidies and price controls, tend to rise more rapidly. Such developments are usually reflected in an observed appreciation of the real exchange rate measures. However, given that the equilibrium real exchange rate also tends to rise during the transition process for the same reasons, it does not necessarily mean that the observed real exchange rate becomes misaligned when appreciating.

100. Figure 12 presents five real exchange rate indicators for Croatia, including the CPIbased real effective exchange rate from the Fund's Information Notice System (INS), the CPI- and PPI-based real exchange rates calculated by the Croatian National Bank (CNB), a partial ULC-based real exchange rate measuring the ULC in Croatia relative to the ones in its main EU trading partners (Italy, Germany, and Austria), and the relative retail price of services to goods as a proxy for the relative price of nontradables to tradables.

101. The two CPI-based real exchange rates from INS and the CNB have been broadly stable since early 1994, with fluctuations not exceeding 10 percent. Recently, the INS index depreciated by about 8 percent between March 1998 and May 1999, before appreciating by 3 percent until September 1999, thus returning to the level observed in mid-1997. The PPIbased exchange rate from the CNB was very close to the CPI-based indicators until November 1998 , but has depreciated by 5-10 percent faster than the CPI-based indicators since then.

${ }^{8}$ For a detailed review of REERs and other competitiveness indicators, see Marsh and Tokarick (1994) and Lipschitz and McDonald (1991). 
Figure 12. Croatia: Real Exchange Rate Indicators, 1994-99

(Index values; June 1995=100) $1 /$

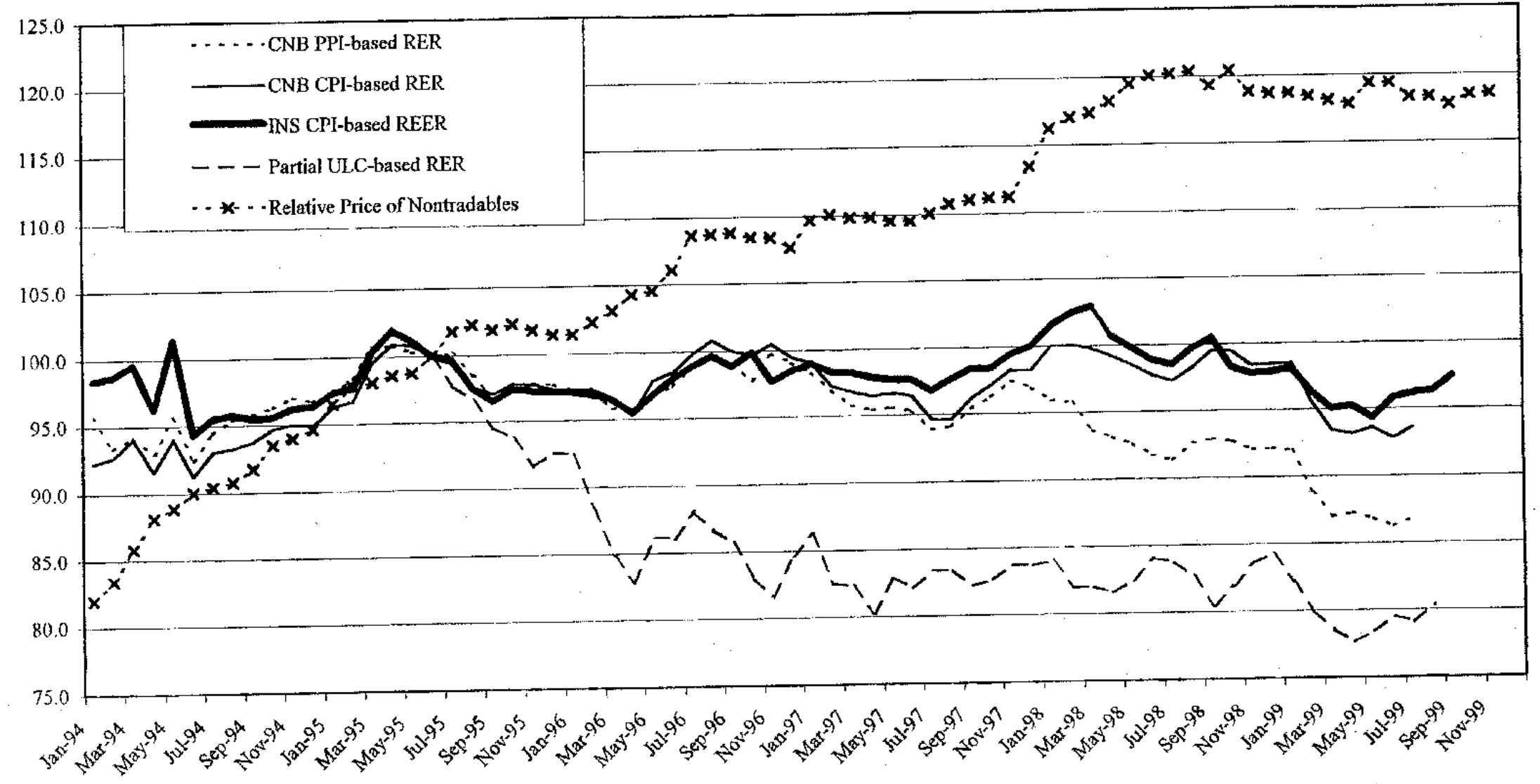

Source: Croatian National Bank; Information Notice System; and Fund staff estimates.

1/ Increase denotes appreciation. 
Figure 13. Unit Labor Costs of Croatia and Its Main Trading Partners, 1995-99

Croatia's Industrial Productivity, Gross Earnings and ULC

(3-month moving average index, June $1995=100$ )

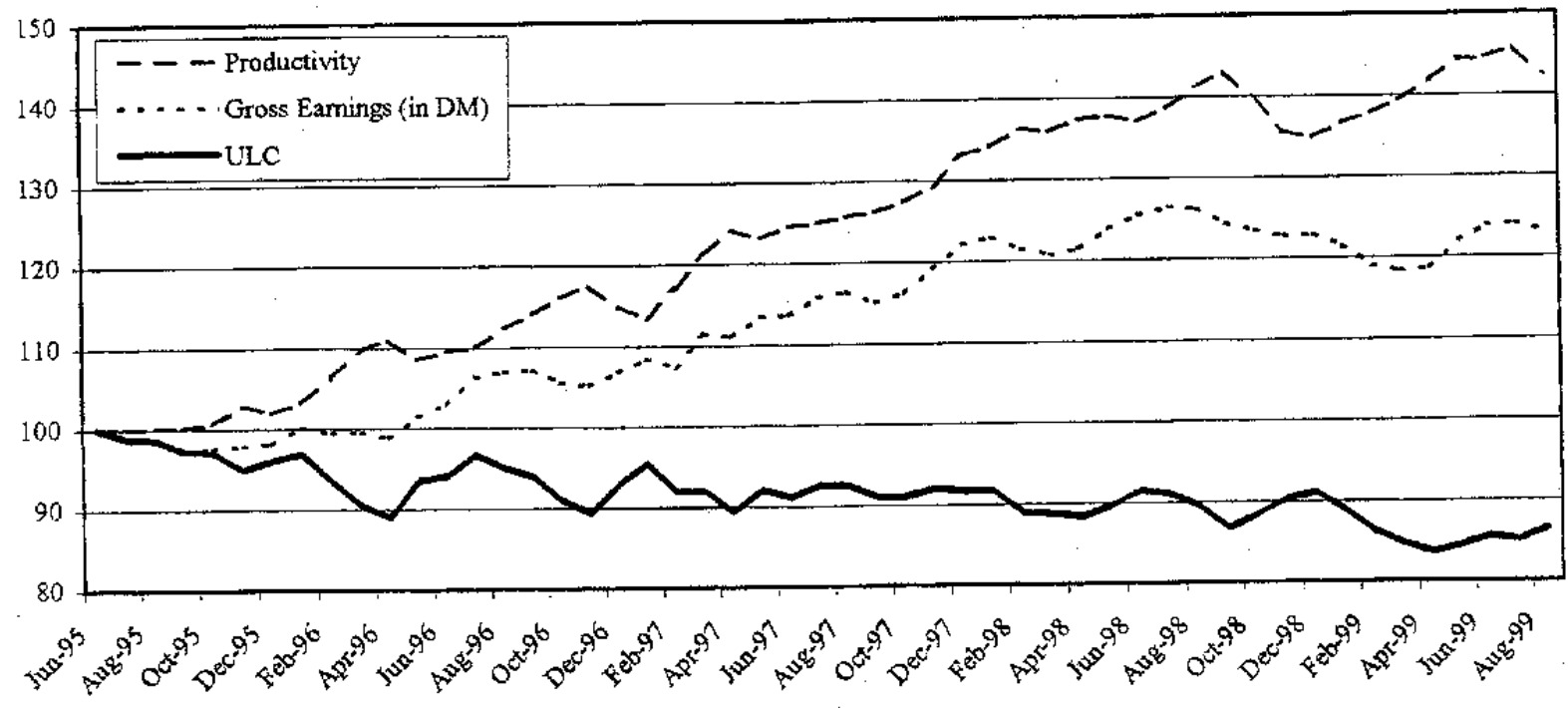

Unit Labor Costs in Croatia and Its Main Trading Partners

(in DM, 3-month moving average index, June 1995=100)

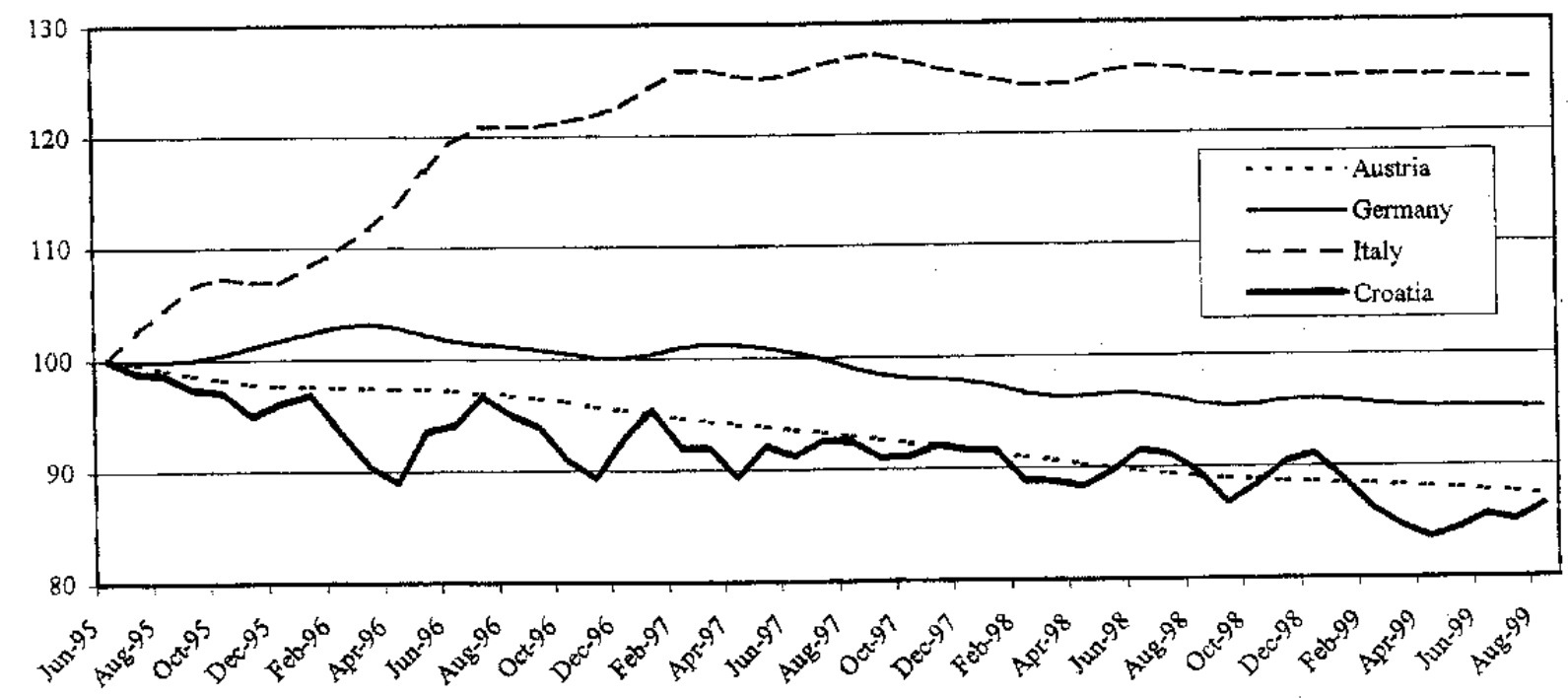

Sources: Croatian Burean of Statistics; and Fund staff estimates. 
102. Regarding the ULC-based measure, Figure 13 indicates that productivity growth has outpaced the increase in industrial wages since mid-1995. Average gross industrial wages expressed in DM increased by about 25 percent between mid-1995 and mid-1998, but have been broadly stable since then. The larger growth in measured productivity, particularly strong between mid-1995 and mid-1998, largely reflects a decrease in industrial employment during this period, which points to the need of accelerating structural reforms if such productivity gains are to be maintained in the future. Nevertheless, Croatia's industrial ULC (expressed in DM) has experienced a declining trend during the last four years, which compares favorably with ULC developments in Italy, Germany, and Austria, Croatia's main EU trading partners. As a result, the ULC-based real exchange rate, calculated as the relative ULC of Croatia to a weighted average of Italy, Germany and Austria' ULCs (with weights based on Croatia's export shares to these countries), depreciated by about 15 percent from mid-1995 to mid-1996, and has fluctuated around a slowly depreciating trend since then.

103. The relative retail price of services to that of goods is the only one of the five real exchange rate measures to exhibit a strong appreciation since 1994. Measured in this way, the real exchange rate appreciated by nearly 50 percent from early 1994 to mid-1998, but has stabilized since then. This marked appreciation, however, is probably not an indication of a loss in external competitiveness, as it mainly reflects the progressive removal of subsidies from public services, which represent a large share of services in the retail price basket; overall improvements in the quality of services, which were reportedly of relatively poor quality in the early $1990 \mathrm{~s}$, and which translated into a more rapidly growing price index for services as the index is not corrected for quality effects; and possibly some higher productivity growth in the tradables sector.

104. The moderate developments in Croatia's REER are even more striking when compared with REERs in other CEECs. Figure 14 presents the INS CPI-based REER for Croatia and the selected sample of CEECs, which is the only readily available measure of the real exchange rate for all the countries in the sample. During 1994-99, several other CEECs experienced significant real exchange rate appreciation, up to 90 percent from January 1994 to September 1999. Croatia had in fact the lowest appreciation of the sample, with only Hungary having experienced comparable developments. As several of these countries registered at the same time significant exchange rate appreciation and substantial export growth, it reinforces the point that changes in external competitiveness as measured by real exchange rates cannot account for much, if any, of Croatia's relatively weak export performance since 1994.

105. These developments in observed real exchange rate indices should be gauged against possible developments in the equilibrium real exchange rate during 1994-98, in order to draw conclusions as to whether Croatia's currency exchange rate became misaligned. The usual methodology for evaluating the equilibrium rate consists of estimating it based on a set 
Figure 14. Central and Eastern Europe: Real Exchange Rate Developments, 1994-99 (Index values; $1994 \mathrm{MI}=100$ )
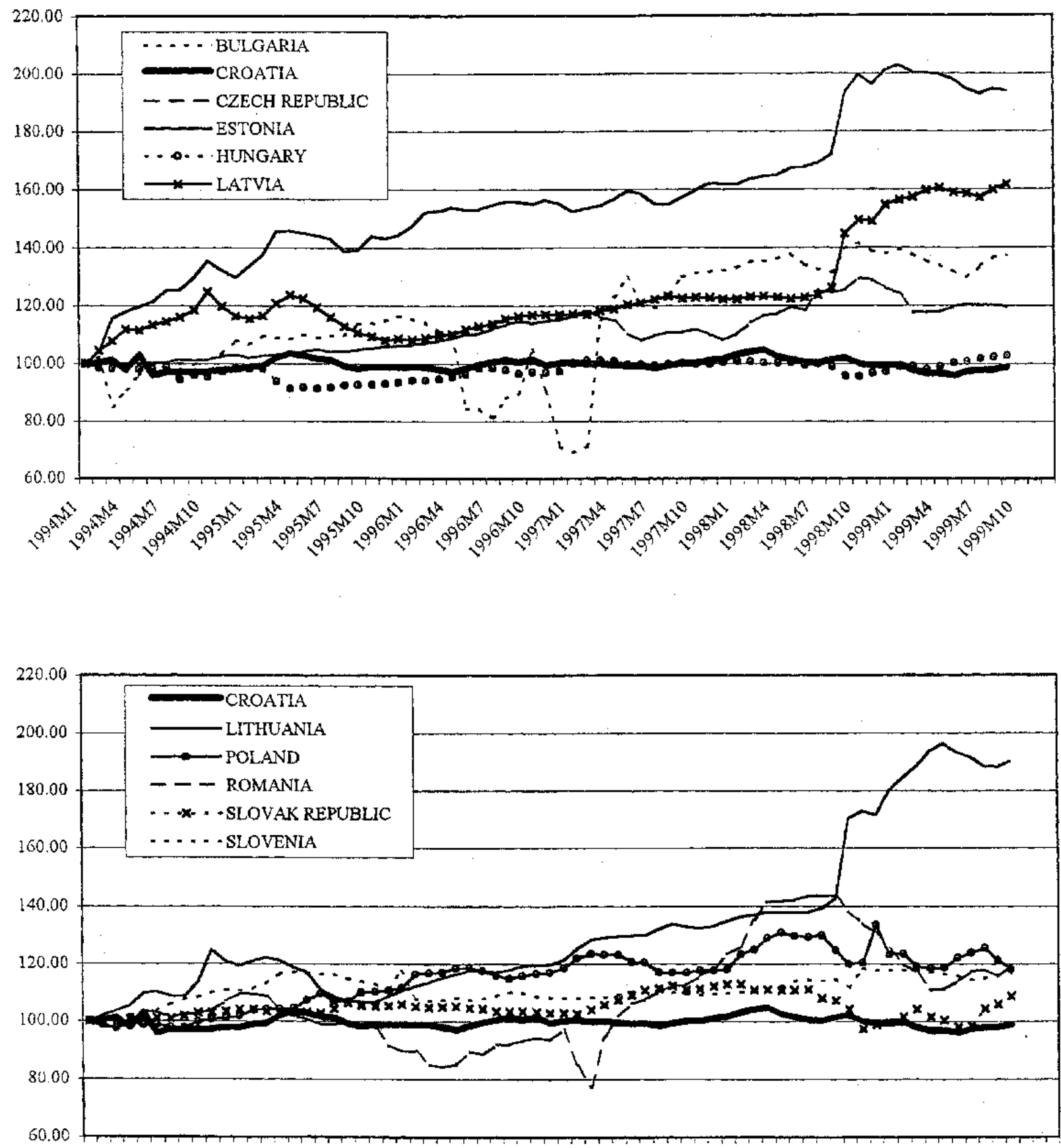

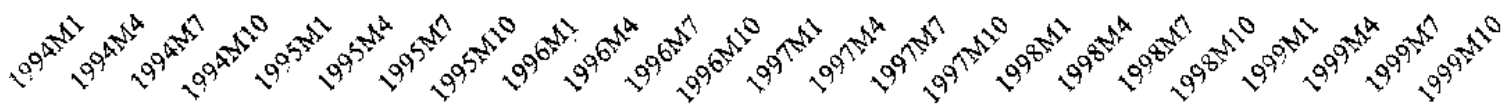

Source: Infornation Notice System 
of fundamental determinants. ${ }^{9}$ The traditional determinants include: differential productivity growth between tradables and nontradables (the Balassa-Samuelson effect, often proxied by a time trend); the composition of government expenditure between tradables and nontradables (usefully proxied by the ratio of government investment to GDP); external environment factors, including terms of trade, external transfers, and international real interest rates; and trade liberalization (usually proxied by the foreign trade to GDP ratio). The determinants found to be the most significant usually include the differential productivity growth, the terms of trade, and trade liberalization. Data limitations preclude conducting an econometric analysis for Croatia, but one can look at broad developments of the fundamental

determinants. As in other transition economies, productivity growth has probably been higher in the tradable than in the nontradable sector, albeit the differential may have been lower than in other transition economies. Terms of trade are not available for Croatia, but composite indices calculated in the WEO for Croatia's export and import deflators would indicate that Croatia did not experience any large fluctuation in its terms of trade over the period. While Croatia progressively liberalized its trade regime (see below), the trade ratio (total exports and imports over GDP) decreased from 75 percent to 70 percent during 1994-95. Regarding nondebt creating transfers, net FDI increased from the equivalent of 0.7 percent of GDP in 1994 to 3.6 percent in 1998 . All of these determinants would have contributed to an appreciation of the equilibrium exchange rate. On the other hand, the consolidated central government investment ratio increased by about 31/2 percentage points of GDP between 1994 and 1998. On balance, it thus seems that Croatia's equilibrium exchange rate has at least been stable since 1994, if not appreciated.

106. Given the shortcomings of traditional competitiveness indicators mentioned above, especially for transition economies, recent research has attempted to estimate equilibrium exchange rates indirectly. ${ }^{10}$ Specifically, equilibrium dollar wages have been estimated based on such fundamental factors as Purchasing Power Parity GDP per capita, secondary school enrollment as an indicator of the stock of human capital, and the share of agriculture in GDP as an indicator of the level of development. These estimates should also be interpreted with caution, as they are sensitive to the underlying data and are based on possibly overly strong assumptions, such as the stability of the relationships between equilibrium wages and their fundamentals during a period of large transformation of transition economies. Nevertheless, the analysis carried out by Halpern and Wyplosz (1997) indicates that Croatia had one of the highest equilibrium dollar wages among CEECs, just below that of Slovenia. This would tend to explain the higher actual dollar wages of Croatia compared with most other CEECs in recent years (see Table below) by differences in fundamentals, such as a more advanced stage of development and relatively higher human capital.

${ }^{9}$ See Clark et al. (1994) and Montiel (1997) for a discussion of the determinants of the equilibrium real exchange rate.

${ }^{10}$ See Halpern and Wyplosz (1997) and Krajnyak and Zettelmeyer (1998). 
Dollar Industrial Wages in Selected CEECs, 1996-99 1/

(in U.S. dollars)

\begin{tabular}{lccrr}
\hline & 1996 & 1997 & 1998 & 1999 \\
& & & & $2 /$ \\
\hline Bulgaria & 106 & 107 & 144 & 154 \\
Croatia & 587 & 566 & 596 & 567 \\
Czech Republic & 348 & 338 & 370 & 350 \\
Hungary & 322 & 320 & 325 & 312 \\
Poland & 372 & 368 & 397 & 455 \\
Romania & 148 & 127 & 160 & 130 \\
Slovak Republic & 280 & 284 & 292 & 256 \\
Slovenia & 604 & 572 & 602 & 618 \\
& & & & \\
\hline
\end{tabular}

Source: Staff estimates.

1/ Average gross monthly wages in the industrial sector, except for Slovenia for which net wages are presented.

2/ Data for 1999 refer to averages of monthly data up to the latest available month, which is August 1999 for Croatia and May 1999 for most of the other countries.

107. In conclusion, there seems to be very little evidence, if any, that Croatia's poor export performance since 1994 could be attributed to significant losses of external competitiveness.

\section{Trade Liberalization Since Independence}

108. At the time of independence, Croatia inherited from the former SFRY a trade system which, despite having been progressively liberalized in the last years before the breakup of the federation, included significant nontariff barriers and was subject to a complex tax system. Imports were classified in four lists: a free list; two lists of items subject to value and volume quotas, respectively; and a list subject to ad hoc licensing. Items on the free list, just under 6,000 out of a total of about 6,600 , comprised about 90 percent of the value of imports. Of the restricted items, only 0.1 percent of total imports were subject to licensing, 1.6 percent were subject to value quotas and 8.6 percent to volume quotas. The import tax system included not only tariffs but also special taxes and fees. Import tariffs ranged from 0 to 25 percent. ${ }^{11}$ In addition, imports were subject to a tax for equalization of traded goods of $0-15$ percent, a special import tax of $0-15$ percent, ${ }^{12}$ and a customs administration fee of

${ }^{11}$ The maximum tariff rate was reduced to 18 percent following the dissolution of the SFRY.

${ }^{12}$ A special import tax of 0-7.5 percent was applied to all imported goods except some, mostly consumer goods, to which a special import tax of up to 15 percent was applied. 
1 percent. ${ }^{13}$ Imports of raw materials and intermediate products used in the production of exports could enter Croatia duty free if the export value was at least 30 percent higher than the value of the imported items, and were only subject to the 1 percent customs fee. Imports by nonresidents for investment purposes were also duty free. By contrast, exports were not subject to any tax, but export proceeds had to be collected and repatriated in full to Croatia within 60 days of the date of exportation.

109. In the post-independence period, the trade system was substantially liberalized. The process of eliminating import quotas began in 1994 and was completed in July 1996, when the Croatian government adopted a decree abolishing all import quotas with immediate effect. Quantitative restrictions had been maintained until that time on certain agricultural products, some foodstuffs, textile fibers, cement, iron and steel products, and machinery to protect some industries which were being restructured and assist areas damaged by war.

110. In June 1996, a new Customs Tariff Law was adopted by parliament which abolished the application of nontariff measures and incorporated all import taxes into the customs tariff, resulting in a higher maximum tariff. The current customs tariff consists of 7,059 tariff lines. All tariff items are subject to ad valorem tariffs, and 590 tariff items are subject to both $a d$ valorem and specific duty rates. The ad valorem rates on industrial products range from 0 to 25 percent (see Table below) ${ }^{14}$. The basic criteria for determining tariff rates are that: (i) tariffs were the only trade policy measure applied to protect domestic industrial and agricultural production; (ii) tariffs were a function of economic development, in particular the technological rehabilitation of the economy; (iii) rates exceeding 15 percent were applied only to protect industries and activities seriously damaged by war, including agricultural products; and (iv) very low tariff rates were applied to imported raw materials.

Croatia: Import Tariff Structure

\begin{tabular}{rc}
\hline Tariff rate & Number of tariff items \\
\hline 0 & 505 \\
$0-5$ & 3,038 \\
$5-10$ & 828 \\
$10-15$ & 883 \\
$15-20$ & 1,260 \\
20 and above & 545 \\
\hline
\end{tabular}

Source: Ministry of Economy

${ }^{13}$ In addition, a surcharge on imports of luxury goods of 7.5 percent was introduced in October 1992.

${ }^{14}$ Rates on some agricultural products exceed 25 percent. The average rate on agricultural products is about 35 percent. 
111. The simple average tariff rate is 12.1 percent and the weighted average tariff was 9.0 percent based on 1998 imports. The simple average tariff of Croatia compares favorably with the median of all IMF members of 12.7 percent, but is slightly higher than the average and median of the sample of CEECs introduced earlier, of 11.8 percent and 11.6 percent, respectively (see Table 16). Coupled with the absence of nontariff barriers, Croatia has an overall rating of 2 on the 10-point index of trade restrictiveness prepared by the Trade Policy Division of the IMF, which is below the average of the CEEC sample of 2.7. Further lowering of import tariffs is scheduled over the next five years in the context of the expected accession of Croatia to the World Trade Organization (WTO), which would make Croatia's tariff one of the lowest among the CEECs (see below).

112. Exports are not subject to any tariffs or taxes. Export quotas, which were introduced in July 1996 in exceptional cases, including for the purpose of ensuring supplies to the domestic market and protecting nonrenewable natural resources were abolished again between end-1997 and the beginning of $1999 .^{15}$ Also, Croatia does not apply any export subsidies.

113. Overall, the fairly liberal trade regime does not seem to have been an impediment to Croatia's export performance.

\section{E. Preferential Trade Relations and WTO Accession}

114. The CEECs, in general, have actively sought closer political and economic relations with the EU, and, to a lesser extent, with the member countries of the European Free Trade Association (EFTA). Many of them were also able to secure their accession to the WTO. At the same time, the CEECs have tried to rebuild traditional markets within Central Europe through bilateral trade arrangements and the foundation of the CEFTA in 1993. By contrast, Croatia has not negotiated any new trade arrangements with either the EU or EFTA, nor has it participated in regional free trade agreements. Croatia was also able to make substantial progress in the process of accession to WTO only recently.

115. Croatia enjoyed the benefits of preferential trade agreements with the EU long before the rest of the CEECs. The SFRY concluded a number of trade agreements with the EU from 1970 onward, including a trade and cooperation agreement in 1980 . Following the dissolution of the SFRY, the EU decided to continue to apply the commercial terms of the agreement to all the former Yugoslav republics. This preferential access has certainly resulted in historically higher volumes of Croatian exports to the EU relative to other CEECs, until these CEECs gained preferential access to the EU.

116. Table 17 provides a summary of the current status of trade relations between the EU and the major CEECs. The main vehicle that the EU has offered for promoting trade and development within the CEECs and closer EU-CEEC trade links has been the Association

\footnotetext{
${ }^{15}$ Items subject to export quotas included corn, crude oil, natural gas, wood, raw leather, glass, and newspaper waste. Quotas had been set for a maximum period of one year.
} 
Agreements. ${ }^{16}$ These Agreements are, in effect, stepping stones to eventual full membership of the EU. The primary benefit for a CEEC of an Association Agreement is that the EU is obliged to phase out all statutory tariffs on CEEC industrial goods more rapidly than the CEEC is required to eliminate its own tariffs on EU goods. ${ }^{17}$

117. Croatia, the other former Yugoslav republics with the exception of Slovenia, and Albania are the only CEECs that have not signed Association Agreements with the EU. Many Agreements with CEECs came into effect in the mid-1990s, except for the Baltics and Slovenia, for which agreements came into effect in 1998 and 1999, respectively. ${ }^{18}$ Although there has been some debate about the impact of Association Agreements upon CEEC-EU trade, the absence of such an Agreement has probably adversely affected Croatian exports to the EU in three ways. First, the majority of CEEC products have been subject to lower EU tariffs than Croatian exports, which has raised the price of Croatian products relative to those produced in other CEECs. Second, the harmonization of product standards and the elimination of other nontariff trade barriers called for under the Association Agreements have put Croatian products to a further disadvantage relative to the other CEECs. Third, the strict rules of origin clauses included in the Association Agreements have likely diverted trade away from Croatia and toward other CEECs with Association Agreements. ${ }^{19}$ Thus, the progressive switch from more to less favorable trade relations with the EU relative to other CEECs may have been a significant factor behind the loss in market share of Croatian exports to the EU.

118. Croatia is also not a member of CEFTA. The requirements for membership in CEFTA include WTO membership and an Association Agreement with the EU. Croatia does not fulfill either of those requirements yet. Members of CEFTA are gradually eliminating tariff and nontariff barriers on all industrial goods and on a limited number of agricultural

${ }^{16}$ See IMF Staff Country Reports No 98/90, 1998, "Republic of Croatia-Selected Issues and Statistical Appendix", Section II, for a detailed discussion of the various facilities offered by the EU for promoting trade and development in the CEECs.

${ }^{17}$ In general, the Association Agreements give the CEEC signatories a 10-year transition period during which all tariffs on industrial goods must be eliminated. The EU, however, continued until recently to impose quotas on so-called sensitive industrial goods such as textiles, clothing, and footwear.

${ }^{18}$ Slovenia, however, has benefited from an EU Interim Agreement since January 1997, which allowed the early implementation of the trade-related aspects of the more comprehensive Association Agreement.

${ }^{19}$ In order to qualify for EU trade preferences, CEEC products must contain a significant value added component produced either locally or within the EU. In order to encourage intraCEEC trade, the EU introduced cumulation provisions, which enable countries that are party to Association Agreements to consider inputs from other countries with similar agreements as local content. 
products toward each other. The low share of Croatia's exports directed to CEFTA countries of less than 15 percent, of which about 10 percent to Slovenia, may reflect tariff and nontariff barriers in place in those countries. ${ }^{20}$ The proximity of these markets and long borders with some of them would suggest that the gains from membership could be significant. Croatia also has only a couple of bilateral free trade agreements in place, with the Former Yugoslav Republic of Macedonia and Slovenia. A free trade agreement between Croatia and the Federation of Bosnia and Herzegovina was cancelled in May 1999. By comparison, other CEECs have signed many more bilateral free trade agreements with bilateral partners in Central and Eastern Europe.

119. Another disadvantage for Croatia of not having preferential trade agreements with the EU and other CEECs is that FDI inflows may be adversely affected. In particular, tradecomplementing FDI, which tries to exploit the comparative advantage of the host country and typically expands the export-oriented sector, may be diverted from Croatia ${ }^{21}$ Croatia has received slightly lower FDI compared with other CEECs during 1994-98 (see Table below). In addition, a significant share of FDI in Croatia reportedly reflected equity investments, and "greenfield" FDI was very low. Nevertheless, while Estonia, Hungary and Latvia received during this period a disproportionate amount of FDI relative to other CEECs, Croatia received more FDI than Slovenia or Poland. With the privatization process accelerating in 1999 , Croatia is likely to compare more favorably in the next few years. However, without significant progress in the relations with the EU and CEFTA countries, "greenfield" FDI will probably remain low in the coming years. ${ }^{22}$

${ }^{20}$ Slovenia's high share is in part explained by the existence of a bilateral trade agreement.

${ }^{21}$ Given the small domestic market, there is also little incentive for trade-substituting FDI to capture domestic market share.

${ }^{22}$ As noted in Chapter I, paragraph 24, "greenfield" investment may also have been attracted to other CEECs by the provision of more favorable corporate income tax treatment. 
Central and Eastern European Countries: Cumulative FDI, 1994-98

(In percent of cumulative GDP)

\begin{tabular}{lc}
\hline & \\
Bulgaria & 2.3 \\
Croatia & 2.2 \\
Czech Republic & 3.3 \\
Estonia & 5.1 \\
Hungary & 5.0 \\
Latvia & 6.3 \\
Lithuania & 3.3 \\
Poland & 1.9 \\
Romania & 2.6 \\
Slovenia & 0.9 \\
Slovak Republic & 1.2 \\
& \\
AVERAGE & 3.1 \\
(standard deviation) & $(1.7)$ \\
MEDIAN & 2.6 \\
\hline
\end{tabular}

Source: World Economic Outlook.

120. With the process of acceding to WTO membership in the final stage (see below), the Croatian authorities would like to concentrate their efforts on CEFTA membership. To this end, as noted, Croatia will need to sign an Association Agreement with the EU. In the context of the EU initiative for the Balkans, this may require that Croatia sign the Stability Pact agreement, which in turn involves political considerations. New perspectives in that regard may open up following the parliamentary and presidential elections in early 2000 . The authorities hope that negotiation with the EU on an Association Agreement could be concluded fairly quickly, possibly before end-2000. This would in turn pave the way for closer trade relations with the CEFTA countries, some of which have been reluctant to sign any preferential trade agreement with Croatia before an agreement between Croatia and the EU has been concluded. As a result, Croatia has not been able to sign any bilateral trade agreement with CEFTA countries, except for Slovenia. Ongoing negotiations with Hungary may nevertheless be concluded in the near future.

121. Croatia is in the final stages of the WTO accession process, which began in 1993 and became very intensive during the last two years. During this period, several laws were amended or passed to ensure compliance with WTO principles. Trade policy, as noted, was liberalized, with all nontariff barriers being eliminated and various import levies replaced with WTO acceptable ad valorem tariffs. The Trade Law, which was adopted by parliament on June 30,1999 , also contained provisions on anti-dumping measures, countervailing duties, safeguard measures, and rules of origin to bring Croatian legislation in these areas in compliance with WTO requirements. A new Customs Law was adopted on June 30, 1999, which brought customs valuation provisions in conformity with the relevant Article of the 
GATT. The Banking Law, which entered into effect in late 1998, is also WTO compliant. The excise law was amended in October 1998 and June 1999 to ensure equal treatment between domestic and foreign products, in particular for alcoholic beverages and tobacco products, thus bringing all excise taxes into conformity with Article III of the GATT. Finally, several laws were adopted in the area of intellectual property rights in June 1999 to harmonize Croatia's legislation with the requirements of the Trade-Related Intellectual Property System (TRIPS) Agreement. ${ }^{23}$ In addition, Croatia has no trade-related investment measures (TRIMs) in place, and is ready to apply the TRIMs Agreement from the date of accession to the WTO. At a formal WTO Working Party meeting which was held at endSeptember 1999, all parties acknowledged that all Croatian laws were compliant with WTO principles.

122. To become a member of WTO, Croatia also committed to a tariff-binding schedule, which should come into effect in January 2000 . Under this schedule, which was accepted by all WTO Working Parties at the meeting at end-September 1999, tariffs will be further lowered over the next 3-7 years. First, the simple average import tariff on industrial goods will decrease to about 5.5 percent within 3-5 years. Regarding agricultural products, the average tariff will decrease from about 35 percent currently to about 14 percent over a period of 5 years, with the transition period being extended to 7 years for some sensitive items, and the highest tariff rate on agricultural products will be brought down to 18 percent.

123. Croatia has all but completed the bilateral negotiations with the 16 countries which requested such negotiations at the beginning of the WTO accession process. The bilateral negotiations covered three areas: industrial products, agricultural products, and services. Negotiations on industrial and agricultural products have been completed, although discussions on agriculture have been difficult with some partners. Negotiations on services were also virtually completed before an issue about audiovisual services came up. One EU member country objected to a clause included in the bilateral agreement between Croatia and the U.S. regarding the opening of the Croatian market in the audiovisual sector. As Croatia cannot amend its commitments under its bilateral agreement without the approval of the other party, the Croatian authorities are now waiting for a compromise to be found between the U.S. and the EU in this area. Such a compromise would remove the last obstacle to Croatia's accession to the WTO, which could come into effect immediately thereafter.

\section{F. Summary and Conclusions}

124. Croatia's export performance has been weak in the last five years compared with other CEECs, as Croatia failed to participate in the rapid expansion of CEEC exports to the EU. While CEEC exports were reoriented toward the EU and gained market shares in this

${ }^{23}$ The new laws included a Trademark Law, a Law on Geographical Indications, a Patent Law, a Law on Industrial Design, and a Law on the Topographies of Integrated Circuits. In the area of copyright, Croatia intends to introduce a new Law on Copyright and Neighboring Rights, but has in the interim ensured compliance with the TRIPS Agreement by amending the existing Copyright Law. 
market, Croatia experienced a decrease in its exports to the EU and resulting large losses of market share. Similarly, Croatian exports to CEFTA countries have been subdued, while trade within the CEFTA area and between CEFTA countries and other CEECs expanded significantly in recent years.

125. There is little evidence, if any, that Croatia's weak export performance could be attributed to a loss of external competitiveness. While most of CEECs experienced, sometimes significant, CPI-based real exchange rate appreciation, Croatia's real exchange rate indicators have been remarkably stable since 1994 . There is also no indication that Croatia's equilibrium exchange rate may have depreciated over the period, therefore not pointing to any misalignment of Croatia's current exchange rate. In addition, higher dollar wages in Croatia compared with most other CEECs can be explained by differences in fundamentals, such as a more advanced stage of development and relatively higher human capital.

126. As part of the SFRY, Croatia enjoyed the benefits of preferential trade arrangements with the EU long before the rest of the CEECs. In the last decade, however, most of the CEECs have signed EU Association Agreements and have favorable prospects for joining the EU, while Croatia has been unable to secure any improvement in its trade arrangements with the EU. The progressive switch from more to relatively less favorable trade relations with the EU has most likely been a significant factor behind the poor Croatian export performance, as Croatian products have faced higher tariff barriers, and the strict rules of origin clauses included in Association Agreements have discouraged other CEECs from using Croatian inputs. In addition, the absence of an Association Agreement with the EU may have been detrimental to "greenfield" FDI inflows in Croatia. Croatia should thus seek closer trade relations with the EU and the CEFTA countries. New perspectives in that regard may open up following the parliamentary and presidential elections in early 2000.

127. The structure of Croatian exports, especially to the EU, has changed the least among the CEECs. This may have reflected a slower pace of restructuring of the Croatian economy as a whole compared with other transition economies, which could have impeded the adaptation of Croatian products to the demand in industrial countries. The structural reform program would thus need to be accelerated, also to sustain strong productivity gains which so far have been achieved at the expense of decreasing employment.

128. Croatia has liberalized its trade regime since its independence, but more needs to be done in order to make Croatia's trade regime one of the most liberal among the CEECs. Reforms scheduled in the context of the WTO accession would achieve this goal. In that regard, Croatia made substantial progress and is now in the final stages of the WTO accession process. The only remaining obstacle to Croatia's membership to the WTO concerns an issue about the audiovisual sector, which, in effect, is beyond the control of the Croatian authorities. 


\section{References}

Clark, Peter et al., 1994, “Exchange Rates and Economic Fundamentals", IMF Occasional Paper No. 115.

Halpern, Laszlo and Charles Wyplosz, 1997, "Equilibrium Exchange Rates in Transition Economies", IMF Staff Papers, Vol. 44, No. 4.

Krajnyak, Kornelia and Jeromin Zettelmeyer, 1998, "Competitiveness in Transition Economies: What Scope for Real Appreciation?”, IMF Staff Papers, Vol. 45, No. 2.

Lipschitz, Leslie and Donogh McDonald, 1991, "Real Exchange Rates and Competitiveness: A Clarification of Concepts, and Some Measurements for Europe" IMF Working Papers WP/91/25.

Marsh, Ian W. and Stephen P. Tokarick, 1994, "Competitiveness Indicators: A Theoretical and Empirical Assessment" IMF Working Papers WP/94/29.

Montiel, Peter J., 1997, "Exchange Rate Policy and Macroeconomic Management in ASEAN Countries" in Macroeconomic Issues Facing ASEAN Countries, ed. by John Hicklin et al., Washington: International Monetary Fund. 
Table 15. Central and Eastern European Countries: Export Performance Indicators

\begin{tabular}{|c|c|c|c|c|c|c|c|c|c|c|}
\hline \multirow[b]{2}{*}{$:$} & \multirow[t]{2}{*}{$\begin{array}{l}\text { Growth of exports } \\
\text { of goods and non- } \\
\text { factor services } \\
\text { (1994-98) 1/ }\end{array}$} & \multirow[t]{2}{*}{$\begin{array}{l}\text { Growth of exponts } \\
\text { of goods (1994- } \\
98) 1 /\end{array}$} & \multirow[t]{2}{*}{$\begin{array}{l}\text { Growth of exports } \\
\text { of goods to EU } \\
(1994-98) 1 /\end{array}$} & \multicolumn{3}{|c|}{$\begin{array}{l}\text { Share of exports of goods and nonfactor } \\
\text { gervices in GDP }\end{array}$} & \multicolumn{2}{|c|}{$\begin{array}{l}\text { Share of exports to EU in total } \\
\text { exports of goods }\end{array}$} & \multirow{2}{*}{$\begin{array}{l}\text { Change in market } \\
\text { share in the EU } \\
(1994-98)\end{array}$} & \multirow{2}{*}{$\begin{array}{c}\text { Index of change in } \\
\text { structure of exports } \\
\text { to } \mathrm{EU}(1994-98) \\
2 /\end{array}$} \\
\hline & & & & 1994 & 1998 & ge (in \%) & 1994 & 1998 & & \\
\hline BULGARIA & $10.4 \%$ & $9.1 \%$ & $57.5 \%$ & $54.3 \%$ & $47.5 \%$ & $-12.6 \%$ & $47 \%$ & $52 \%$ & $10.6 \%$ & 0.7 \\
\hline CROATIA 3/ & $20.5 \%$ & $8.1 \%$ & $-4.6 \%$ & $48.8 \%$ & $39.4 \%$ & $-19.2 \%$ & $59 \%$ & $49 \%$ & $-33.0 \%$ & 0.5 \\
\hline CZECH REPUBLIC & $60.1 \%$ & $65.2 \%$ & $100.1 \%$ & $51.4 \%$ & $59.9 \%$ & $16.6 \%$ & $53 \%$ & $64 \%$ & $40.5 \%$ & 4.6 \\
\hline ESTONIA & $114.2 \%$ & $82.7 \%$ & $190.1 \%$ & $75.5 \%$ & $77.6 \%$ & $2.8 \%$ & $48 \%$ & $55 \%$ & $103.7 \%$ & 0.8 \\
\hline HUNGARY & $161.7 \%$ & $203.4 \%$ & $133.0 \%$ & $25.8 \%$ & $59.4 \%$ & $130.0 \%$ & $64 \%$ & $73 \%$ & $63.6 \%$ & 5.3 \\
\hline LATVIA & $95.2 \%$ & $80.7 \%$ & $46.6 \%$ & $44.3 \%$ & $49.6 \%$ & $12.0 \%$ & $39 \%$ & $57 \%$ & $3.0 \%$ & 0.5 \\
\hline LITHUANIA & $160.7 \%$ & $147.5 \%$ & $58.2 \%$ & $54.4 \%$ & $56.5 \%$ & $3.7 \%$ & $30 \%$ & $38 \%$ & $11.1 \%$ & 0.6 \\
\hline POLAND & $86.4 \%$ & $85.8 \%$ & $52.1 \%$ & $19.3 \%$ & $21.7 \%$ & $12.0 \%$ & $69 \%$ & $68 \%$ & $6.8 \%$ & 4.3 \\
\hline ROMANIA & $34.8 \%$ & $36.8 \%$ & $71.4 \%$ & $23.6 \%$ & $25.1 \%$ & $6.3 \%$ & $48 \%$ & $65 \%$ & $20.4 \%$ & 1.7 \\
\hline SLOVAK REPUBLIC & $44.8 \%$ & $59.4 \%$ & $132.8 \%$ & $65.1 \%$ & $63.6 \%$ & $-2.2 \%$ & $35 \%$ & $56 \%$ & $63.5 \%$ & 2.0 \\
\hline SLOVENLA & $28.2 \%$ & $28.2 \%$ & $29.1 \%$ & $60.4 \%$ & $55.3 \%$ & $-8.4 \%$ & $63 \%$ & $65 \%$ & $-9.3 \%$ & 1.1 \\
\hline $\begin{array}{l}\text { AVERAGE } \\
\text { (standard deviation) }\end{array}$ & $\begin{array}{r}74.3 \% \\
(53.9)\end{array}$ & $\begin{array}{r}73.4 \% \\
(58.9)\end{array}$ & $\begin{array}{r}78.8 \% \\
(55.5)\end{array}$ & $\begin{array}{r}47.6 \% \\
(17.9)\end{array}$ & $\begin{array}{r}50.5 \% \\
(16.6)\end{array}$ & $\begin{array}{r}12.8 \% \\
(40.4)\end{array}$ & $\begin{array}{r}50.6 \% \\
(12.6)\end{array}$ & $\begin{array}{r}58.3 \% \\
(10.0)\end{array}$ & $\begin{array}{r}25.5 \% \\
(39.0)\end{array}$ & $\begin{array}{r}2.0 \\
(1.8)\end{array}$ \\
\hline MEDLAN & $60.1 \%$ & $652 \%$ & $58.2 \%$ & $51.4 \%$ & $\mathbf{5 5 . 3} \%$ & $3.7 \%$ & $48.2 \%$ & $56.6 \%$ & $11.1 \%$ & 1.1 \\
\hline
\end{tabular}

Sources: WEO; Direction of Trade Statistios (DOTS); and Trade Analysis and Reporting System (TARS) databases.

1/ Exports are expressed in US dollars.

(n) sheres in total exports for each individual SITC 3-digit category between 1994 and 1998.

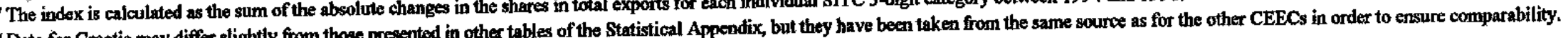


Table 16. Central and Eastern Europe: Tariff Structure Summary and Trade Restrictiveness Rating

\begin{tabular}{|c|c|c|c|c|c|c|c|}
\hline & \multirow{2}{*}{$\begin{array}{c}\text { Simple average } \\
\text { tariff } \\
(1998)\end{array}$} & \multirow{2}{*}{ Minimum } & \multirow{2}{*}{ Maximum } & \multirow{2}{*}{$\begin{array}{l}\text { Import weighted } \\
\text { average tariff } \\
\text { (1998) }\end{array}$} & \multicolumn{3}{|c|}{ Trade restrictiveness index } \\
\hline & & & & & Tariff & NTB & Overall \\
\hline BULGARIA & 15.1 & 0 & 74 & $\ldots$ & 3 & 2 & 6 \\
\hline CROATIA $1 /$ & 12.1 & 0 & 25 & 9.0 & 2 & 1 & 2 \\
\hline CZECH REPUBLIC & 6.9 & 0 & 168 & $\ldots$ & 1 & 1 & 1 \\
\hline ESTONIA & 0.0 & 0 & 0 & 0.0 & 1 & 1 & 1 \\
\hline HUNGARY & 13.3 & 0 & 135 & $\ldots$ & 2 & 2 & 5 \\
\hline LATVIA & 5.3 & 0 & 75 & $\ldots$ & 1 & 1 & 1 \\
\hline LITHUANIA & 4.5 & 0 & 100 & $\ldots$ & 1 & 1 & 1 \\
\hline POLAND & 11.6 & $\ldots$ & $\ldots$ & 5.8 & 2 & 1 & 2 \\
\hline ROMANIA & 19.8 & $\ldots$ & 248 & $\ldots$ & 4 & 1 & 4 \\
\hline SLOVAK REPUBLIC & $7.0 / 10-15$ & $\mathbf{0}$ & 168 & $\ldots$ & 3 & 1 & 3 \\
\hline SLOVENIA & 5.7 & 0 & 40 & $\therefore$ & 1 & 2 & 4 \\
\hline $\begin{array}{l}\text { AVERAGE } \\
\text { (standard deviation) }\end{array}$ & $\begin{array}{r}11.8 \\
(5.9)\end{array}$ & 0.0 & 103.3 & $\cdots$ & $\begin{array}{r}1.9 \\
(1.0)\end{array}$ & $\begin{array}{r}1.3 \\
(0.5)\end{array}$ & $\begin{array}{r}2.7 \\
(1.8)\end{array}$ \\
\hline MEDIAN & 11.6 & 0.0 & 87.5 & $\therefore$ & 2 & 1 & 2 \\
\hline
\end{tabular}

Source: IMF, Trade Policy Division.

1/ The maximum tariff rate of 25 percent refers to industrial products. 
Table 17. Central and Eastem Europe: Trade Arrangements

\begin{tabular}{|c|c|c|c|c|c|c|c|c|c|c|}
\hline & wro & CBFTA & $\begin{array}{l}\text { EU } \\
\text { PHARB }\end{array}$ & $\begin{array}{l}\text { Bilaterel } \\
\text { ugreecenent } \\
\text { with EFTA }\end{array}$ & $\begin{array}{l}\text { Other biliteral } \\
\text { agroommonts }\end{array}$ & $\begin{array}{l}\text { EU Trado and } \\
\text { Cooperstion } \\
\text { Agreenent 1/. }\end{array}$ & $\begin{array}{l}\text { EU Autonomoas } \\
\text { Preferential Trade } \\
\text { Regitano }\end{array}$ & $\begin{array}{l}\text { EU Interion } \\
\text { A Arreement } 1 /\end{array}$ & $\begin{array}{l}\text { EU Aswociantion } \\
\text { Agreerdent 1/ }\end{array}$ & $\begin{array}{l}\text { EUt mutabentip } \\
\text { application }\end{array}$ \\
\hline Bulgaria & Yos & No & Yes & Yes & $\begin{array}{l}\text { Czech Rep, Slovak } \\
\text { Rep, Slovenis, Turkey }\end{array}$ & Novernber 1990 & No & Decertiber 1993 & February 1995 & Docember 1995 \\
\hline Croatia & No & No & No & No & $\begin{array}{l}\text { Slovenia, FYR of } \\
\text { Macedoala }\end{array}$ & No & Yes & No & No & $\mathbf{N o}$ \\
\hline Czech Republic $2 / 3$ / & Yen & Yes & $Y_{\text {es }}$ & Ye & $\begin{array}{l}\text { Bulgaria, Estonis, } \\
\text { Ierael, Latvia, } \\
\text { Lithuanis, Rotrenia, } \\
\text { Slowak Republic, } \\
\text { Thatkey }\end{array}$ & November 1990 & No & March 1992 & February 1995 & Janunry 1996 \\
\hline Estonia & $Y_{a}$ & No & Yes & Yes & $\begin{array}{l}\text { Czoch Republic, } \\
\text { Poland, Slovii: } \\
\text { Republie, Slovenis, } \\
\text { Turkey, Ukraine }\end{array}$ & March 1993 & No & No & February 1998 & November 1995 \\
\hline Hungary & Yos & Yes & Yes & Yeo & $\begin{array}{l}\text { Ertonis, Irovel, } \\
\text { Slovenia, Turkey }\end{array}$ & Decemiber 1988 & No & March 1992 & February 1994 & March 1994 \\
\hline Latvia & Yos & Yes & Yes & Yes & $\begin{array}{l}\text { Czsech Reprublic, } \\
\text { Slovak Republic, } \\
\text { Slowerie, Ukrino }\end{array}$ & February 1993 & No & No & February 1998 & October 1995 \\
\hline Lithumia & Yes & No & Yes & Yot & $\begin{array}{l}\text { Czech Ropublic, } \\
\text { Poland, Slovak } \\
\text { Ropublic, Slovenia, } \\
\text { Turzey }\end{array}$ & February 1993 & No & No & February 1998 & Docounber 1995 \\
\hline Poland & $Y \infty$ & Yes & Yen & Yes & $\begin{array}{l}\text { Denmark, Eutonia, } \\
\text { Irael, Lithuanis }\end{array}$ & Decernber 1989 & No & March 1992 & Februxry 1994 & April 1994 \\
\hline Romania & Yes & No & Yes & Yes & $\begin{array}{l}\text { Creoh Republic, } \\
\text { Moldove, Stovak } \\
\text { Republic, Iurkey }\end{array}$ & May 1991 & No & May 1993 & February 1995 & June 1995 \\
\hline Slovale Republic 2/3f & Yes & Yer & Yex & Yes & $\begin{array}{l}\text { Bulgaria Czech } \\
\text { Reprublic, Estonia, } \\
\text { Imrool, Latvia, } \\
\text { Iithuania, Romania } \\
\text { Slovenia, Trukey }\end{array}$ & November 1990 & No & March 1992 & February 1995 & Tune 1995 \\
\hline Slovenia & Yos & Yen & Yes & Yos & 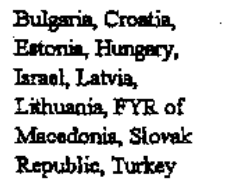 & September 1993 & No & January 1997 & February 1999 & Jume 1996 \\
\hline
\end{tabular}

Sources: BU Sectoral and Trade Barriers Detsbase; and MP Trade Policy Division database.

1/ Date refers to when agreernent carne into force.

2f Tho Crosh Ropublic and the Slovak Republic have a custorus union agreement.

3/ The Czech and Slovak Fedenal Republis (CSFR) signed a Trade and Cooperation Agreonent in May 1990 and an Aseociation Agreenent in December 1991. Following the dissolution of the

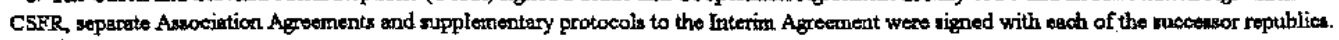




\title{
SUMMARY OF THE CROATIAN EXCHANGE AND TRADE SYSTEM
}

\author{
(Position as of September 30, 1999)
}

\section{Exchange arrangements}

1. Croatia accepted the obligations of Article VIII, Sections 2, 3, and 4 of the Articles of Agreement on May 29, 1995. The currency of Croatia is the kuna, the external value of which is determined in the interbank market. The exchange rates in the interbank market are determined by authorized banks that transact with each other at freely negotiated rates. The Croatian National Bank (CNB) may set intervention exchange rates at which it will transact with banks outside the interbank market for purposes of smoothing undue fluctuations in the exchange rate. On September 30, 1999, the average interbank market rate for the U.S. dollar was HrK 7.249 per US\$1. There are no taxes or subsidies on purchases or sales of foreign exchange. Settlements between residents and nonresidents may be affected in any convertible currency. Croatia does not maintain any bilateral payment agreements.

2. The Law on the Foreign Exchange System, Foreign Exchange Operations, and Gold Transactions, which was enacted on October 7, 1993, governs foreign exchange transactions. The CNB formulates and administers exchange rate policy. The CNB and the Ministry of Finance may issue foreign exchange regulations under this law. A Law on Trade (codifying domestic trade and foreign trade legislation in a comprehensive law) was passed on January 31, 1996, and came into force on February 17, 1996. The Law on Trade has been subsequently amended on June 30, 1999 in order to achieve full compliance of its provisions with the relevant WTO agreements. Companies wishing to engage in foreign companies must be registered with the Ministry of Economy.

3. Foreign exchange transactions must be conducted through authorized banks licensed to conduct foreign exchange transactions. Restricted licenses are given to banks that may open accounts for resident natural persons and may buy and sell banknotes and checks.

\section{Resident and nonresident accounts}

4. Resident natural and juridical persons may, in principle, open and operate foreign exchange accounts only in Croatia. However, the CNB has the authority to allow resident juridical persons to keep foreign exchange in accounts with foreign banks in order to cover the costs of business operations and meet the requirement of regular foreign trade activities abroad. The law also makes specific provisions for resident juridical persons engaged in capital project construction abroad to maintain accounts with foreign banks, subject to a license issued by the CNB.

5. Nonresidents may open foreign exchange accounts with fully licensed banks in Croatia. These accounts may be credited freely with foreign exchange and debited for payments abroad or conversion into domestic currency; reconversion of domestic currency into a foreign currency is permitted. Juridical persons may credit these accounts with foreign banknotes up to a limit of US $\$ 20,000$ per month without special permission from the CNB. 
6. Nonresident natural and juridical persons may open accounts in domestic currency with the proceeds from sales of goods and services or with foreign exchange transferred from abroad. They may purchase foreign exchange with funds held in these accounts without restriction.

\section{Imports and import payments}

7. Croatia does not maintain any import quotas - the existing quotas were abolished by decree of July 12, 1996. All quantitative restrictions, including import quotas can only be applied in situations provided for in relevant WTO agreements. All imports except for a list of products whose importation is controlled by international agreement for noneconomic reasons, including human, animal and plant health, public security, protection of environment, control of trade in works of art and precious metals (such as arms, gold, illegal drugs and narcotics, and artistic and historic works) are free from licensing agreements.

8. Imports are subject to customs tariffs of up to 25 percent. For a number of agricultural and food products combined tariffs (ad valorem+specific tariff per quantity unit) are applied. The exemption for duty-free imports by travelers was US $\$ 100$ until December 1, 1997; since January 1, 1998 this exemption has been changed to HrK 300. Goods imported by travelers and postal shipments up to a value of US\$500 are subject to a simplified customs procedure with a unified tariff rate of 8 percent. For imports exceeding that value, the regular import tariffs and taxes are applied. Returning citizens may bring into the country household effects duty-free in an amount related to the period spent abroad for household effects and for private business purposes without restrictions, but on a case-by-case basis, under the approval of the Ministry of Finance. Under certain conditions, goods imported by nonresidents for investment purposes are exempt from import duties. Also, raw materials and intermediate products used in the production of exports are exempt from all import duties and taxes, provided that the value added on the export product is at least 30 percent of the value of the imported items and that export proceeds are received in convertible currency. Payments for legal imports are not restricted. Advance payments and down payments for imports are permitted.

\section{Payments for invisibles}

9. Payments for invisibles related to legal imports by juridical persons may be made freely. Natural persons may also purchase foreign exchange in the interbank market for the payment of goods and services abroad and for deposits in a foreign exchange account for the purpose of future payments. Payments of royalties, insurance, and legal obligations and contracting of life and casualty insurance policies with foreign companies are also permitted.

10. Resident natural persons may take out of the country-including on short-cross border trips-foreign currency equivalent to DM 1,000. There exist no restrictions on the frequency with which such amounts can be taken out. An additional amount equivalent to DM 2,000 may be taken out, provided that it is withdrawn from foreign currency accounts or purchased from banks for travel expenses. In both cases the CNB may allow higher amounts to be taken out on a case-by-case basis. The exportation of Croatian currency by both 
residents and nonresidents is limited to $\mathrm{HrK} 2,000$ per person, but larger amounts may be exported with special permission from the CNB.

\section{Exports and export proceeds}

11. Exports are free of restrictions, including quantitative restrictions (for WTO members), except that for certain products licenses must be obtained (e.g., weapons, drugs, gold, art objects). Export proceeds must be collected and repatriated in full to Croatia within 90 days of the date of exportation; this period maybe extended with the permission of the CNB up to 150 days. If payment terms in excess of 90 days have been agreed with foreign importers, the credit arrangement must be registered with the CNB.

\section{Proceeds from invisibles}

12. Proceeds from services are, in principle, subject to the same regulations as those applying to merchandise exports. The importation of Croatian currency by both residents and nonresidents is limited to $\mathrm{HrK} 2,000$ a person, but larger amounts may be imported with special permission from the CNB.

\section{Capital account}

13. Resident juridical persons, including commercial banks, may borrow abroad. They are required to register the loans contracted, including commercial credits, with the CNB. Financial credits may be extended to nonresidents by resident juridical persons, only in accordance with the provisions of the Law on Foreign Trade Credit Operations. Natural persons are permitted to obtain loans from nonresidents in domestic or foreign currency. The foreign exchange positions of commercial banks are subject to a limit maximum up to 30 percent of the bank's capital.

14. Foreign direct investment by nonresidents may take the form of joint ventures or full ownership and must be registered with the commercial courts. Repatriation of capital and transfers abroad of profits are not restricted. In principle, domestic and foreign investment is treated equally (e.g., "national treatment"). If the foreign equity capital participation exceeds 20 percent, inputs used in the project are exempt from import duties. The profit tax rate is uniform and amounts to 35 percent. Foreign direct investment abroad by residents must be registered with the Ministry of Economy within a 30-day period from the signing of the contract. Inward portfolio investment is not restricted, except in central bank short-term securities in the primary market. In general, outward portfolio investment is restricted.

15. A new law governing foreign ownership of real estate came into effect on January 1 , 1997. Foreign natural and juridical persons can legally purchase real estate subject to the approval of both the Ministries of Foreign Affairs and Justice. However, the law grants the right of ownership only to those foreign nationals in whose countries Croatian citizens are given reciprocal rights of property ownership. 
16. The CNB may export gold and gold coins without any restrictions. Unprocessed gold may be exported with the approval of the CNB. Gold coins may be exported by authorized commercial banks, with the approval of the CNB. Importation of gold is subject to the approval of the Ministry of Economy.

\section{Changes from July 1, 1995 through September 30, 1999}

December 14, 1995: The Law on Issuance and Sale of Securities was passed and came into force on January 1, 1996.

December 14, 1995: The Law on Investment Funds was passed and came into force on January 3, 1996.

February 17, 1996: The Trade Law became effective.

June 8, 1996: The Law on Foreign Credit Operations became effective.

July 1, 1996: The Law on Customs Tariffs (including unification of various tariffs into a single tariff structure) became effective.

July 12, 1996: A decree abolishing import quotas became effective.

July 31, 1996: An exchange of bonds in the context of an agreement with London Club creditors was effected.

January 1, 1997: The Law on Real Estate Ownership became effective.

June 30, 1999: The new law amending the Law on Trade was passed (ensuring WTO compliance).

June 30, 1999: The new Customs Law was adopted (to take effect as of January 1, 2000). 
SUMMARY OF THE CROATIAN TAX SYSTEM

(Position as of August 31, 1999)

\begin{tabular}{|c|c|c|c|c|}
\hline Tax & Nature of Tax & $\begin{array}{l}\text { Deductons and } \\
\text { Exemptiong }\end{array}$ & Rates & Remarks \\
\hline \multicolumn{5}{|c|}{ 1. Taxes on income, profits and capital goins } \\
\hline 1. Individual Income Tax & $\begin{array}{l}\text { The unified tax is levied on all } \\
\text { personal income and includes } \\
\text { income from employment, small- } \\
\text { business activity and self- } \\
\text { employment, farming and forestry, } \\
\text { and property and property rights. } \\
\text { The tax base for residents is both } \\
\text { income earned domestically and } \\
\text { abroad; foreigners are taxed for } \\
\text { income earned in Croatia. }\end{array}$ & $\begin{array}{l}\text { There is an exempt tax } \\
\text { threshold of HrK } 1,000 \text { per } \\
\text { month (as of Jan. 1, 1997). } \\
\text { This amount increases if } \\
\text { the taxpayer has a } \\
\text { dependent spouse or other } \\
\text { close or disabled family } \\
\text { members and/or children. } \\
\text { As of January } 1,1995 \text {, } \\
\text { allowances for food and } \\
\text { travel are included in the } \\
\text { tax base. Capital gains are } \\
\text { tax exempted. Tax } \\
\text { exemptions granted under } \\
\text { the former Direct Taxes } \\
\text { Act continue to be valid } \\
\text { until they expire. }\end{array}$ & $\begin{array}{l}20 \text { percent on taxable income } \\
\text { up to three annual minimum } \\
\text { salaries (decreased as of } \\
\text { January } 1,1997 \text { from } \\
25 \text { percent); } 35 \text { percent on } \\
\text { taxable income exceeding } \\
\text { three annual minimum } \\
\text { salaries. }\end{array}$ & $\begin{array}{l}\text { The Income Tax Act became } \\
\text { effective January } 1,1994 \text {. } \\
\text { Taxes which are paid abroad } \\
\text { for activities in Croatia can be } \\
\text { deducted from the tax liability } \\
\text { up to the overall liability in } \\
\text { Croatia. }\end{array}$ \\
\hline 1.2 Pront Tax & $\begin{array}{l}\text { The tax is levied on legal entities } \\
\text { as well as natural persons who } \\
\text { engage in regular and for-profit } \\
\text { business activity, and who are } \\
\text { required to keep business books } \\
\text { and have to submit financial } \\
\text { statements. Natural persons who } \\
\text { engage in small business activities } \\
\text { that are covered by the income tax } \\
\text { can choose to pay profit taxes and } \\
\text { keep accounting books instead. } \\
\text { The taxable base is the difference } \\
\text { between the value of assets and } \\
\text { liabilities at the beginning and the } \\
\text { end of the tax period. The tax is } \\
\text { imposed on both residents and } \\
\text { non-residents operating a business } \\
\text { in Croatia. }\end{array}$ & $\begin{array}{l}\text { Exemptions and tax relief } \\
\text { can be granted to } \\
\text { enterprises which invest in } \\
\text { war affected regions. } \\
\text { Taxes which are paid } \\
\text { abroad for activities in } \\
\text { Croatia can be deducted } \\
\text { from the tax liability. } \\
\text { Exemptions that were } \\
\text { granted under the Direct } \\
\text { Taxes Act continue to be } \\
\text { valid until they expire. }\end{array}$ & $\begin{array}{l}\text { As of January } 1,1997 \text {, the } \\
\text { rate was increased from } 25 \text { to } \\
35 \text { percent of the assessed } \\
\text { taxable base. }\end{array}$ & $\begin{array}{l}\text { The Profit Tax Act became } \\
\text { effective January 1, 1994. As } \\
\text { of January } 1,1997 \text {, the tax } \\
\text { base is reduced by a "normal" } \\
\text { rate of retum on equity which } \\
\text { is defined as } 5 \text { percent } \\
\text { increased by the change in the } \\
\text { producer price index } \\
\text { published by the National } \\
\text { Institute for Statistics. }\end{array}$ \\
\hline
\end{tabular}


SUMMARY OF THE CROATIAN TAX SYSTEM

(Position as of August 31, 1999)

\begin{tabular}{|c|c|c|c|c|}
\hline Tax & Nature of Tax & $\begin{array}{l}\text { Deductions and } \\
\text { Exemptions }\end{array}$ & Rates & Remarks \\
\hline $\begin{array}{l}\text { 1.3 Surcharge on Income } \\
\text { Tax } \\
1.4 \text { Gaming Tax }\end{array}$ & $\begin{array}{l}\text { Towns and cities of more than } \\
40,000 \text { inhabitants can impose a } \\
\text { surcharge to be collected by the } \\
\text { cities on the income tax of the } \\
\text { central government. } \\
\text { The tax is levied on individuals } \\
\text { who realize profits from gambling. }\end{array}$ & & $\begin{array}{l}\text { Up to } 30 \text { percent. } \\
\text { City of Zagreb up to } 60 \\
\text { percent. }\end{array}$ & \\
\hline \multicolumn{5}{|c|}{ 2. Social security contributions } \\
\hline $\begin{array}{l}2.1 \text { Employees } \\
\begin{array}{l}2.1 .1 \text { Pension } \\
\text { Fund } \\
2.1 .2 \text { Health Fund } \\
2.1 .3 \\
\text { Employment Fund } \\
\text { 2.1.4 Child } \\
\text { Benefit } \\
\text { Fund }\end{array}\end{array}$ & $\begin{array}{l}\text { The tax is levied on individuals } \\
\text { who receive wages and salaries for } \\
\text { work performed in the country or } \\
\text { abroad if they have been assigned } \\
\text { to a job by a Croatian employer. } \\
\text { The tax takes the form of a Central } \\
\text { Government payroll tax. The } \\
\text { funds are in principle obliged to } \\
\text { balance their budgets, and benefits } \\
\text { are financed on a pay-as-you-go } \\
\text { basis. }\end{array}$ & $\begin{array}{l}\text { No exemptions are } \\
\text { provided. }\end{array}$ & $\begin{array}{l}\text { Standard rates: } \\
\text { Pensions: } \\
10.75 \text { percent } \\
\text { Health: } \\
9.00 \text { percent } \\
\text { Employment: } \\
0.85 \text { percent } \\
\text { Child Benefits: } \\
2.20 \text { percent }\end{array}$ & $\begin{array}{l}\text { On February } 1,1998 \text {, the rate } \\
\text { of the contribution to the } \\
\text { Pension Fund was reduced } \\
\text { from } 12.75 \text { percent to } 10.75 \\
\text { percent, and the rate of the } \\
\text { contribution to the Health } \\
\text { Fund increased from } 7 \\
\text { percent to } 9 \text { percent, for both } \\
\text { employees and employers. } \\
\text { This was intended to offset } \\
\text { the elimination as from that } \\
\text { date of the transfer from the } \\
\text { Persion Fund to the Health } \\
\text { Fund. }\end{array}$ \\
\hline $\begin{array}{l}2.2 \text { Employers } \\
\text { 2.2.1 Pension Fund } \\
2.2 .2 \text { Health Fund } \\
\text { 2.2.3 Employment Fund }\end{array}$ & $\begin{array}{l}\text { Same tax base as for employees' } \\
\text { contributions. }\end{array}$ & $\begin{array}{l}\text { No exemptions are } \\
\text { provided. }\end{array}$ & $\begin{array}{l}\text { Pensions: } \\
10.75 \text { percent } \\
\text { Health: } \\
9.00 \text { percent } \\
\text { Employment: } \\
0.85 \text { percent } \\
\text { Water Management } \\
0.76 \text { percent }\end{array}$ & . \\
\hline
\end{tabular}


SUMMARY OF THE CROATIAN TAX SYSTEM

(Position as of August 31, 1999)

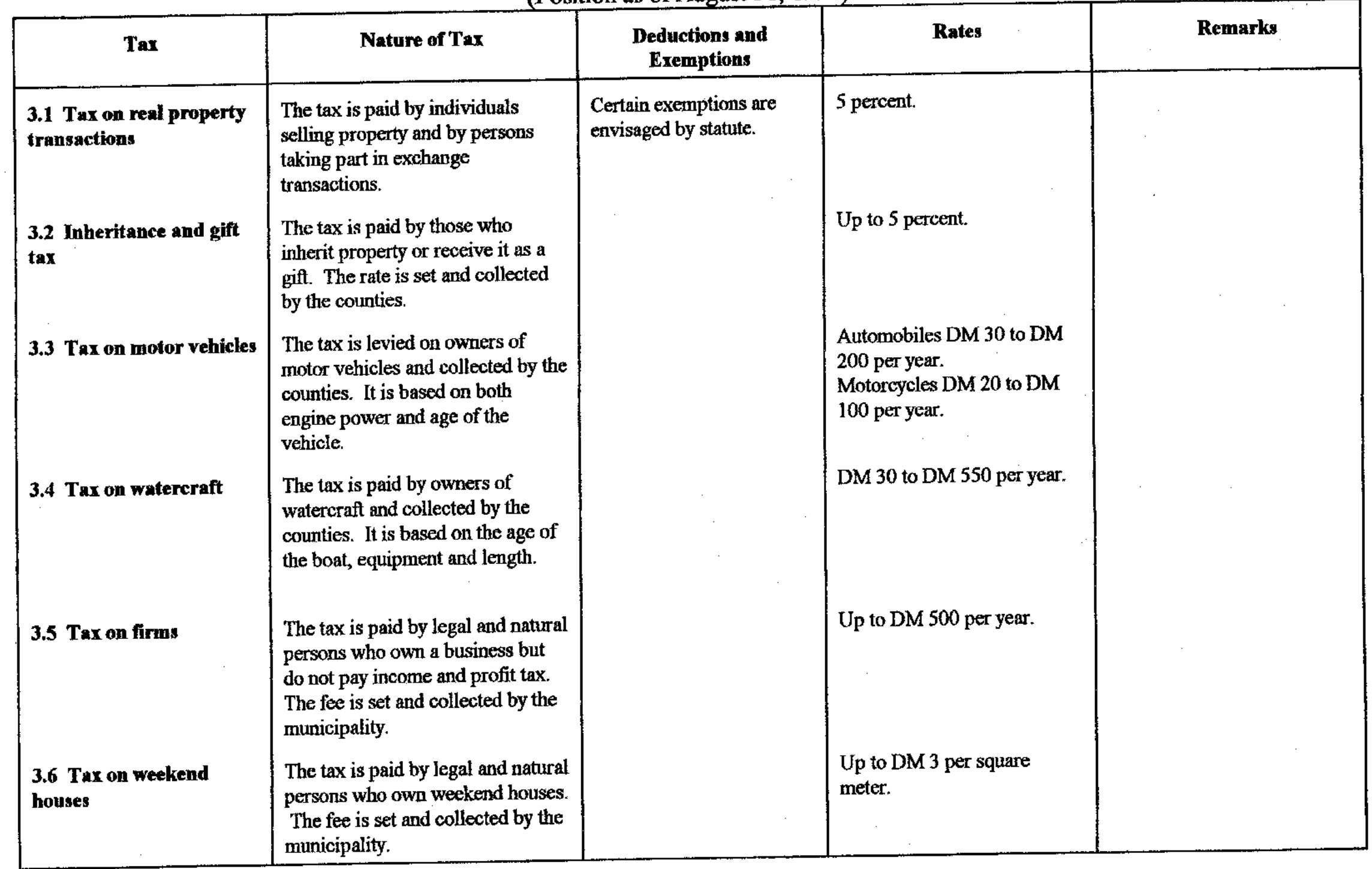




\section{SUMMARY OF THE CROATIAN TAX SYSTEM}

(Position as of August 31, 1999)

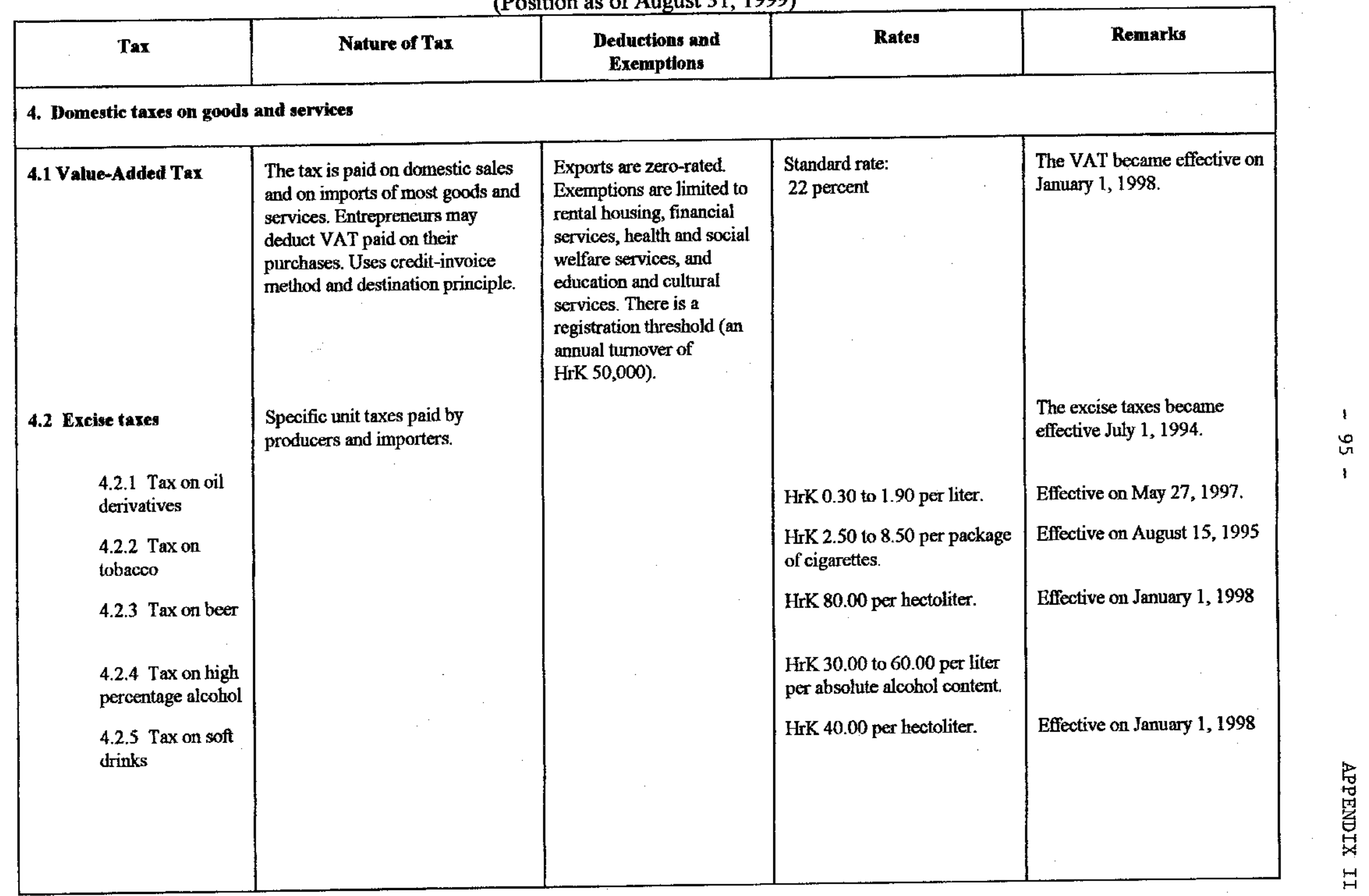


SUMMARY OF THE CROATIAN TAX SYSTEM

(Position as of August 31, 1999)

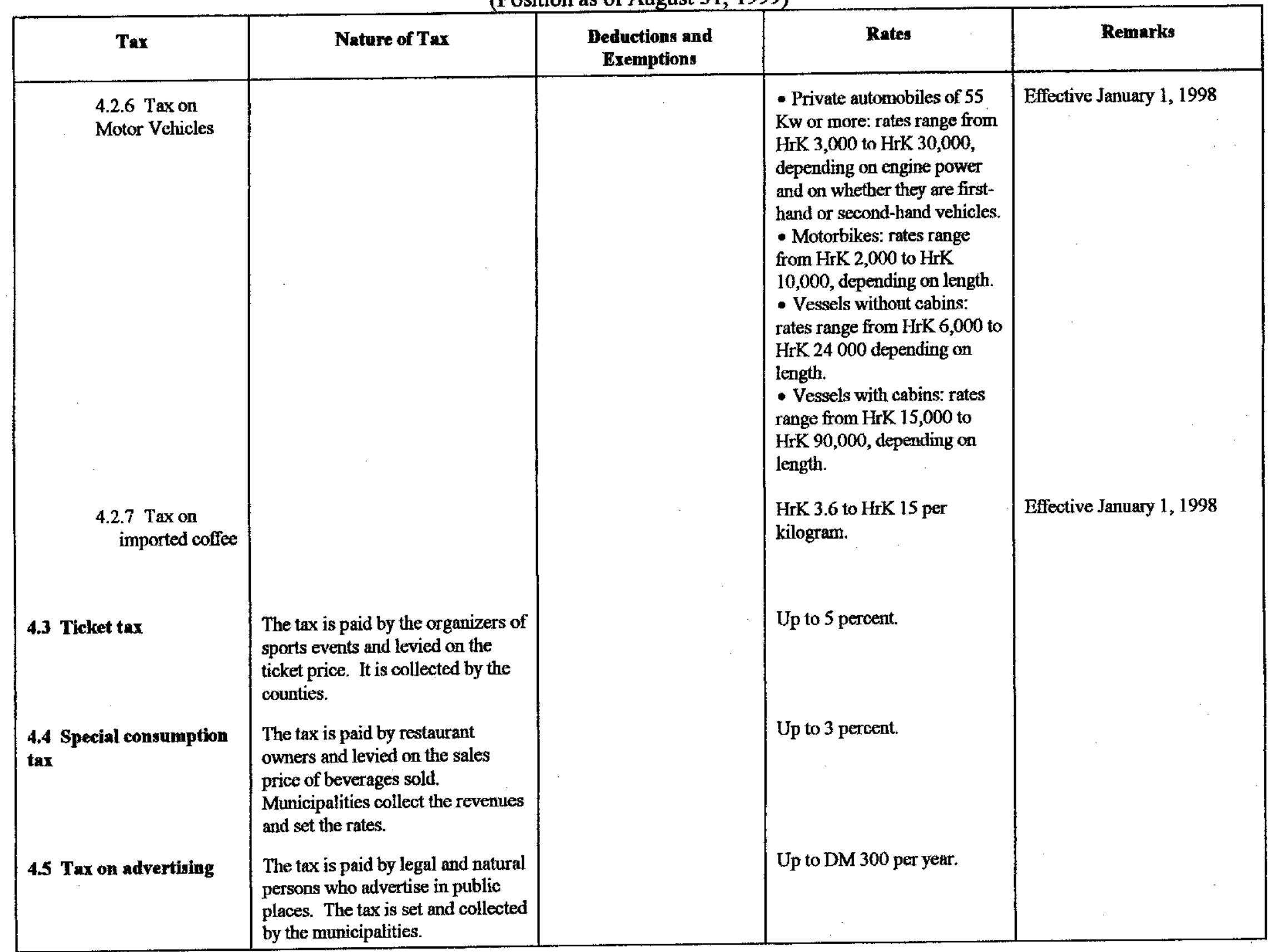


SUMMARY OF THE CROATIAN TAX SYSTEM

(Position as of August 31, 1999)

\begin{tabular}{|c|c|c|c|c|}
\hline Tax & Nature of Tax & $\begin{array}{l}\text { Deductions and } \\
\text { Exemptions }\end{array}$ & Rates & Remarks \\
\hline \multicolumn{5}{|c|}{ 5. Taxes on international trade and trangactions } \\
\hline 5.1 Import duties & & & & \\
\hline $\begin{array}{l}\text { 5.1.1 Customs } \\
\text { duties }\end{array}$ & $\begin{array}{l}\text { Paid by the importer of a wide } \\
\text { range of goods and services }\end{array}$ & $\begin{array}{l}\text { A large number of items } \\
\text { are not considered customs } \\
\text { goods (e.g., movable } \\
\text { property owned by } \\
\text { Croatian citizens, } \\
\text { enterprises, and other legal } \\
\text { persons; certain foreign } \\
\text { personal investments in } \\
\text { domestic enterprises and } \\
\text { retail shops; imports which } \\
\text { will be used mainly for } \\
\text { production of goods for } \\
\text { exports). }\end{array}$ & $\begin{array}{l}\text { Most tariff rates are in the } \\
5-25 \text { percent range. }\end{array}$ & \\
\hline
\end{tabular}


Table 18. Croatia: Quarterly GDP at Constant 1997 Prices, 1991-99 1/

\begin{tabular}{|c|c|c|}
\hline & $\begin{array}{c}\text { GDP } \\
\text { (In millions of kunas) }\end{array}$ & $\begin{array}{l}\text { Index } \\
1990=100\end{array}$ \\
\hline \multicolumn{3}{|l|}{1991} \\
\hline Q1 & 32.0 & 84.6 \\
\hline Q2 & 32.9 & 86.9 \\
\hline Q3 & 28.7 & 75.8 \\
\hline $\mathrm{Q} 4$ & 25.9 & 68.3 \\
\hline Total & 119.4 & 78.9 \\
\hline \multicolumn{3}{|l|}{1992} \\
\hline $\mathrm{Q} 1$ & 25.6 & 67.7 \\
\hline $\mathrm{Q}^{2}$ & 26,0 & 68.8 \\
\hline $\mathrm{Q3}$ & 27.1 & 71.6 \\
\hline Q4 & 26.7 & 70.6 \\
\hline Totsl & 105.4 & 69.7 \\
\hline \multicolumn{3}{|l|}{1993} \\
\hline $\mathrm{Q1}$ & 23.8 & 63.0 \\
\hline Q2 & 24.4 & 64.4 \\
\hline$Q 3$ & 24.8 & 65.5 \\
\hline Q4 & 24.0 & 63.4 \\
\hline Total & 97.0 & 64.1 \\
\hline \multicolumn{3}{|l|}{1994} \\
\hline Q1 & 24.0 & 63.4 \\
\hline $\mathrm{Q}_{2}$ & 25.1 & 66.4 \\
\hline Q3 & 27.1 & 71.7 \\
\hline Q4 & 26.4 & 69.8 \\
\hline Total & 102.7 & 67,8 \\
\hline \multicolumn{3}{|l|}{1995} \\
\hline $\mathrm{Q} 1$ & 26.6 & 70.3 \\
\hline Q2 & 27.5 & 72.7 \\
\hline $\mathrm{Q3}$ & 27.9 & 73.8 \\
\hline Q4 & 27.6 & 73.0 \\
\hline Total & 109.7 & 72.5 \\
\hline \multicolumn{3}{|l|}{1996} \\
\hline Q1 & 27.5 & 72.6 \\
\hline Q2 & 28.7 & 75.9 \\
\hline$Q^{3}$ & 30.6 & 81.0 \\
\hline Q4 & 29.4 & 77.8 \\
\hline Total & 116.3 & 76.8 \\
\hline \multicolumn{3}{|l|}{1997} \\
\hline Q1 & 28.0 & 73.9 \\
\hline Q2 & 30.0 & 79.3 \\
\hline Q3 & 32.5 & 85.8 \\
\hline Q4 & 33.4 & 88.2 \\
\hline Total & 123.8 & 81.8 \\
\hline \multicolumn{3}{|l|}{1998} \\
\hline Q1 & 29.6 & 78.1 \\
\hline Q2 & 31.7 & 83,8 \\
\hline Q3 & 33.7 & 89.1 \\
\hline $\mathrm{Q} 4$ & 32.0 & 84.5 \\
\hline Total & 126.9 & 83.9 \\
\hline \multicolumn{3}{|l|}{1999} \\
\hline Q1 & 29.1 & 76.9 \\
\hline Q2 & 31.5 & 83.3 \\
\hline
\end{tabular}

Source: Central Bureas of Statistics.

1/ Following the publication of a new quarterly GDP serics in June 1999, data from 1997 onwards has been revised. Earlier data is is rebased but not revised. 
Table 19. Croatia: Gross Value Added and Gross Domestic Product at Current Prices, 1995-98 1/

\begin{tabular}{|c|c|c|c|c|}
\hline & 1995 & 1996 & 1997 & $19982 /$ \\
\hline & \multicolumn{4}{|c|}{ (In millions of kunas) } \\
\hline Agriculture, munting, and forestry & $8,193.9$ & $8,887.4$ & $9,471.2$ & $9,673.6$ \\
\hline Fishing & 219.0 & 171.4 & 216.5 & 167.2 \\
\hline Mining and quarrying & 238.0 & 234.9 & 645.9 & 616.3 \\
\hline Mamufacturing & $19,177.6$ & $19,660.2$ & $22,791.4$ & $32,880.8$ \\
\hline Electricity, gas, and water supply & $3,023.3$ & $3,411.3$ & $3,675.5$ & $4,438.7$ \\
\hline Construction & $4,625.2$ & $5,965.1$ & $7,437.0$ & $7,807,2$ \\
\hline Wholesale and retail trade & $9,502.4$ & $11,121.6$ & $13,050.9$ & $13,250.7$ \\
\hline Hotels and restaurants & $2,049.8$ & $2,731.8$ & $3,266.3$ & $3,421.0$ \\
\hline Transport, storage, and communication & $7,805.4$ & $8,022.3$ & $9,091,7$ & $10,608.0$ \\
\hline Financial intermediation & $3,312.3$ & $3,952.3$ & $4,043.7$ & $5,428.1$ \\
\hline Real estate, renting, and business activities. & $8,452.3$ & $9,362.5$ & $10,649.9$ & $12,211.1$ \\
\hline Public administration and defense; compulsory social security & $7,055.4$ & $8,241.9$ & $9,548.7$ & $11,877.7$ \\
\hline Education & $2,863.0$ & $3,433.8$ & $3,864.6$ & $4,870.2$ \\
\hline Health and social work & $2,609.7$ & $3,522.2$ & $4,441.4$ & $5,398.8$ \\
\hline Other & $1,996.1$ & $2,161.5$ & $2,512.6$ & $2,839.4$ \\
\hline FISIM & $-2,240.9$ & $-2,793.7$ & $-3,788.2$ & $-5,056.2$ \\
\hline Gross value added (basic prices) & $78,882.5$ & $88,086.7$ & $100,918.9$ & $110,532.7$ \\
\hline Taxes on products less subsidies on products & $19,499.5$ & $19,893.9$ & $22,891.8$ & $27,859.0$ \\
\hline \multirow[t]{2}{*}{ GDP (market prices) } & $98,382.0$ & $107,980.6$ & $123,810.7$ & $138,391.7$ \\
\hline & \multicolumn{4}{|c|}{ (Percent composition) } \\
\hline Agriculture, hunting, and forestry & 8.3 & 8.2 & 7.6 & 7.0 \\
\hline Fishing & 0.2 & 0.2 & 0.2 & 0.1 \\
\hline Mining and quarrying & 0.2 & 0.2 & 0.5 & 0.4 \\
\hline Manufacturing & 19.5 & 18.2 & 18.4 & 16.6 \\
\hline Electricity, gas, and water supply & 3.1 & 3.2 & 3.0 & 3.2 \\
\hline Construction & 4.7 & 5.5 & 6.0 & 5.6 \\
\hline Whole and retail trade & 9.7 & 10.3 & 10.5 & 9.6 \\
\hline Hotels and restaurants & 2.1 & 2.5 & 2.6 & 2.5 \\
\hline Transport, storage, and communication & 7.9 & 7.4 & 7.3 & 7.7 \\
\hline Financial intermediation & 3.4 & 3.7 & 3.3 & 3.9 \\
\hline Real estate, renting, and business activities & 8.6 & 8.7 & 8.6 & 8.8 \\
\hline Public administration and defense; compulsory social security & 7.2 & 7.6 & 7.7 & 8.6 \\
\hline Education & 2.9 & 3.2 & 3.1 & 3.5 \\
\hline Health and social work & 2.7 & 3.3 & 3.6 & 3.9 \\
\hline Other & 2.0 & 2.0 & 2.0 & 2.0 \\
\hline FISIM & -2.3 & -2.6 & -3.1 & -3.7 \\
\hline Gross value added (basic prices) & 80.2 & 81.6 & 81.5 & 79.9 \\
\hline Taxes on products less subsidies on products & 19.8 & 18.4 & 18.5 & 20.1 \\
\hline GDP (market prices) & 100.0 & 100.0 & 100.0 & 100.0 \\
\hline
\end{tabular}

Source: Central Bureau of Statistics.

$1 /$ Revised series based on the national classification of economic activities 2/ Preliminary estimates. 
Table 20. Croatia: Gross Domestic Product at Constant Prices, 1996-98 1/

(Annual percentage change)

\begin{tabular}{lrrr}
\hline & 1996 & 1997 & 19982 \\
& & & \\
& & & \\
Agriculture, hunting and forestry & 1.8 & 2.4 & 3.8 \\
Fishing & -20.4 & -3.4 & -2.6 \\
Mining and quarrying & -3.0 & 0.1 & -2.4 \\
Manufacturing & 1.7 & 4.3 & 2.7 \\
Electricity, gas and water supply & 20.8 & 24.4 & 8.7 \\
Construction & 18.8 & 13 & 3.2 \\
Wholesale and retail trade & 15.6 & 13.2 & -0.6 \\
Hotels and restaurants & 21.8 & 18.1 & 3.4 \\
Transport, storage and communication & 7.0 & 3.5 & 3.7 \\
Financial intermediation & 1.3 & 6.3 & 8.4 \\
Real estate, renting and business activities & 2.5 & 5.2 & 4.2 \\
Public administration and defense; compulsory social security & 2.3 & 2 & 2.3 \\
Education & 0.7 & 3.7 & 3.5 \\
Health and social work & 1.7 & 3.0 & 1.1 \\
Other community, social and personal service activities & 2.5 & 5.9 & 5.1 \\
Private households with employed persons & 27.2 & 14.7 & 42.7 \\
FISIM & 5.1 & 9.5 & 7.2 \\
Taxes on products less subsides on products & 5.4 & 5.6 & 5.8 \\
GDP (market prices) & 5.9 & 6.8 & 2.5 \\
& & & \\
\hline
\end{tabular}

Source: Central Bureau of Statistics.

1/ Prices of the previous year. Revised series based on the national classification of economic activities.

2/ Preliminary estimates. 
Table 21. Croatia: Trends in Industrial Production, 1992-99

(Industrial production by main industrial groupings, 1992=100)

\begin{tabular}{|c|c|c|c|c|c|c|}
\hline & $\begin{array}{l}\text { Total } \\
\text { Industry }\end{array}$ & Energy & $\begin{array}{c}\text { Intermediate } \\
\text { Goods, Except } \\
\text { Energy }\end{array}$ & $\begin{array}{l}\text { Capital } \\
\text { Goods }\end{array}$ & $\begin{array}{l}\text { Durable } \\
\text { Consumer } \\
\text { Goods }\end{array}$ & $\begin{array}{l}\text { Nondurable } \\
\text { Consumer } \\
\text { Goods }\end{array}$ \\
\hline 1992 & 100.0 & 100.0 & 100.0 & 100.0 & 100.0 & 100.0 \\
\hline 1993 & 94.0 & 114.5 & 97.4 & 107.4 & 108.5 & 78.2 \\
\hline 1994 & 91,4 & 116.9 & 98.2 & 78.9 & 105.7 & 83.3 \\
\hline 1995 & 91.7 & 133,9 & 90.2 & 81.5 & 93.2 & 88.4 \\
\hline 1996 & 94.6 & 146.5 & 97.1 & 86.5 & 93.6 & 82.8 \\
\hline 1997 & 101.0 & 171.3 & 95.2 & 92.3 & 122.7 & 92.6 \\
\hline 1998 & 104.8 & 177.6 & 99.0 & 93.6 & 120.6 & 96.6 \\
\hline \multicolumn{7}{|l|}{1993} \\
\hline Q1 & 94.7 & 124.0 & 99.6 & 108.6 & 113.4 & 76.6 \\
\hline Q2 & 94.9 & 109.1 & 99.6 & 119.4 & 113.5 & 73.8 \\
\hline Q3 & 90.8 & 106.3 & 95.9 & 96.2 & 99.9 & 78.1 \\
\hline$Q 4$ & 95.6 & 118.6 & 94.5 & 105.5 & 107.3 & 84.5 \\
\hline \multicolumn{7}{|l|}{1994} \\
\hline Q1 & 87.1 & 125.0 & 91.0 & 70.5 & 105.2 & 79.6 \\
\hline Q2 & 90.3 & 102.9 & 103.2 & 82.1 & 106.2 & 77.9 \\
\hline Q3 & 90.5 & 119.1 & 97.4 & 72.0 & 97.0 & 84.6 \\
\hline Q4 & 97.8 & 120.6 & 101.1 & 90.9 & 114.5 & 91.1 \\
\hline \multicolumn{7}{|l|}{1995} \\
\hline Q1 & 91.7 & 148.8 & 89.4 & 77.6 & 97.5 & 85.1 \\
\hline Q2 & 92.6 & 135.5 & 94.3 & 82.0 & 95.6 & 86.4 \\
\hline Q3 & 87.2 & 120.1 & 87.3 & 75.7 & 91.3 & 85.4 \\
\hline Q4 & 95.4 & 131.1 & 89.8 & 90.7 & 88.4 & 96.9 \\
\hline \multicolumn{7}{|l|}{1996} \\
\hline Q1 & 91.7 & 161.1 & 92.0 & 79.5 & 90.7 & 78.5 \\
\hline Q2 & 93.9 & 131.2 & 98.6 & 93.7 & 90.5 & 79.5 \\
\hline Q3 & 93.0 & 132.4 & 98.3 & 87.8 & 97.2 & 82.2 \\
\hline $\mathrm{Q4}$ & 99.6 & 1612.0 & 99.5 & 85.1 & 96.1 & 91.1 \\
\hline \multicolumn{7}{|l|}{1997.} \\
\hline Q1 & 94.3 & 186.7 & 86.5 & 83.0 & 115.5 & 83.6 \\
\hline$Q 2$ & 100.2 & 157.3 & 97.3 & 93.4 & 138.1 & 92.2 \\
\hline Q3 & 98.8 & 147.3 & 89.1 & 88.6 & 114.7 & 97.2 \\
\hline Q4 & 110.6 & 194.1 & 107.9 & 104.1 & 122.6 & 97.4 \\
\hline \multicolumn{7}{|l|}{1998} \\
\hline Q1 & 100.3 & 193.0 & 94.1 & 90.5 & 119.0 & 87.2 \\
\hline $\mathrm{Q} 2$ & 105.3 & 147.9 & 105.7 & 101.5 & 122.9 & 95.8 \\
\hline Q3 & 107.5 & 165.4 & 97.7 & 94.7 & 121.5 & 106.5 \\
\hline Q4 & 106.0 & 204.2 & 98.3 & 87.6 & 119.0 & 96.7 \\
\hline \multicolumn{7}{|l|}{1999} \\
\hline Q1 & 96.7 & 228.3 & 86.2 & 77.6 & 116.0 & 82.4 \\
\hline $\mathrm{Q}_{2}$ & 105.0 & 175.9 & 104.9 & 88.2 & 128.4 & 92.7 \\
\hline $\mathrm{Q3}$ & 102.6 & 165.8 & 97.6 & 92.4 & 128.3 & 94.1 \\
\hline
\end{tabular}

Source: Central Bureau of Statistics. 
Table 22. Croatia: Agricultural Production, 1991-98

(Previous year $=100$ )

\begin{tabular}{|c|c|c|c|c|c|c|c|c|}
\hline & 1991 & 1992 & 1993 & 1994 & 1995 & 1996 & 1997 & 1998 \\
\hline Total production - net & 92.8 & 86.5 & 104.9 & 97.0 & 100.7 & 101.6 & 103.4 & 109.9 \\
\hline Field crops & 101.8 & 68.6 & 115.7 & 100.3 & 108.4 & 100.6 & 107.8 & 109.0 \\
\hline Cereals & 106.7 & 60.5 & 126.4 & 93.8 & 107.2 & 98.5 & 114.8 & 103.5 \\
\hline Industrial crops & 94.8 & 80.7 & 100.6 & 90.0 & 104.5 & 110.5 & 105.4 & 142.6 \\
\hline Meadow crops & 104.4 & 67.3 & 103.7 & 107.5 & 102.1 & 99.5 & 113.2 & 102.1 \\
\hline Fruit & 138.6 & 103.7 & 81.6 & 81.6 & 111.4 & 127.9 & 71.6 & 111.9 \\
\hline Viniculture & 107.2 & 96.3 & 104.3 & 91.7 & 93.4 & 110.0 & 108.8 & 103.7 \\
\hline Stock-raising & 75.9 & 100.8 & 92.0 & 98.3 & 92.8 & 99.3 & 103.0 & 107.7 \\
\hline Cattle & 74.0 & 117.4 & 88.8 & 94.4 & 93.4 & 98.4 & 97.1 & 100.8 \\
\hline Pigs & 73.0 & 99.6 & 97.2 & 101.3 & 91.1 & 98.4 & 102.0 & 110.7 \\
\hline
\end{tabular}

Source: Central Bureau of Statistics. 
Table 23. Croatia: Tourism-Overnight Stays, 1989-99

(In thousands)

\begin{tabular}{|c|c|c|c|}
\hline & \multicolumn{3}{|c|}{ Overnight Stays } \\
\hline & Total & Domestic & Foreign \\
\hline 1989 & 61,849 & 7,383 & 54,466 \\
\hline 1990 & 52,523 & 6,747 & 45,776 \\
\hline 1991 & 10,158 & 3,394 & 6,764 \\
\hline 1992 & 10,724 & 3,170 & 7,554 \\
\hline 1993 & 12,909 & 3,152 & 9,757 \\
\hline 1994 & 19,977 & 4,421 & 15,556 \\
\hline 1995 & 12,885 & 4,370 & 8,515 \\
\hline 1996 & 21,455 & 4,909 & 16,546 \\
\hline 1997 & 30,314 & 5,617 & 24,697 \\
\hline 1998 & 31,287 & 5,285 & 26,002 \\
\hline \multicolumn{4}{|l|}{1997} \\
\hline Jan. & 260 & 174 & 86 \\
\hline Feb. & 295 & 187 & 108 \\
\hline Mar. & 496 & 230 & 266 \\
\hline Apr. & 591 & 233 & 358 \\
\hline May & 1,524 & 340 & 1,184 \\
\hline Jun. & 2,946 & 477 & 2,469 \\
\hline Jul. & 8,944 & 1,418 & 7,526 \\
\hline Aug. & 11,286 & 1,619 & 9,667 \\
\hline Sep. & 2,924 & 431 & 2,493 \\
\hline Oct. & 537 & 210 & 327 \\
\hline Nov. & 251 & 151 & 100 \\
\hline Dee. & 260 & 147 & 113 \\
\hline \multicolumn{4}{|l|}{1998} \\
\hline Jan. & 271 & 183 & 88 \\
\hline Feb. & 294 & 182 & 112 \\
\hline Mar. & 361 & 204 & 157 \\
\hline Apr. & 763 & 246 & 517 \\
\hline May & 1,357 & 314 & 1,043 \\
\hline Jun. & 3,566 & 478 & 3,088 \\
\hline Jul. & 9,042 & 1,355 & 7,687 \\
\hline Aug. & 11,465 & 1,506 & 9,959 \\
\hline Sep. & 3,112 & 349 & 2,763 \\
\hline Oct. & 564 & 191 & 373 \\
\hline Nov. & 249 & 145 & 104 \\
\hline Dec. & 243 & 133 & 110 \\
\hline \multicolumn{4}{|l|}{1999} \\
\hline Jan & 252 & 168 & 84 \\
\hline Feb. & 259 & 157 & 102 \\
\hline Mar. & 324 & 167 & 157 \\
\hline Apr. & 595 & 223 & 372 \\
\hline May & 1,102 & 285 & 817 \\
\hline Jun. & 2,620 & 473 & 2,147 \\
\hline Jul. & 7,975 & 1,427 & 6,548 \\
\hline Aug. & 9,717 & 1,483 & 8,234 \\
\hline
\end{tabular}

Source: Central Bureau of Statistics. 
Table 24. Croatia: Nights Spent by Tourists According to Type of Accommodation, 1992-98

(In thousands)

\begin{tabular}{|c|c|c|c|c|c|c|c|}
\hline & 1992 & 1993 & 1994 & 1995 & 1996 & 1997 & 1998 \\
\hline & \multicolumn{7}{|c|}{ (Total nights spent) } \\
\hline Hotels & 4,983 & 5,729 & 8,433 & 5,587 & 8,551 & 11,247 & 11,387 \\
\hline Pensions & 15 & 23 & 21 & 15 & 31 & 51 & 58 \\
\hline Motels & 100 & 82 & 103 & 95 & 111 & 140 & 89 \\
\hline Overnight lodging houses & 32 & 21 & 27 & 29 & 41 & 42 & 43 \\
\hline Tourist facilities & 1,648 & 2,178 & 3,357 & 1,972 & 3,083 & 3,791 & 3,667 \\
\hline Inns and other food and lodging establishments & 2 & 2 & 2 & 2 & 5 & 40 & 67 \\
\hline Spas and sanatoriums & 300 & 199 & 283 & 262 & 172 & 207 & 166 \\
\hline Company vacation facilities & 140 & 139 & 248 & 303 & 401 & 685 & 574 \\
\hline Vacation facilities for children and adolescents & 61 & 107 & 219 & 192 & 225 & 372 & 370 \\
\hline Campgrounds & 2,651 & 3,562 & 5,079 & 3,429 & 5,815 & 7,857 & 8,650 \\
\hline $\begin{array}{l}\text { Housekeeping facilities - private rooms, } \\
\text { apartments, villas and weekend cottages }\end{array}$ & 709 & 748 & 2,054 & 840 & 2,806 & 5,660 & 6,020 \\
\hline Other & 84 & 119 & 151 & 159 & 215 & 224 & 196 \\
\hline \multirow[t]{2}{*}{ Total } & 10,725 & 12,908 & 19,977 & 12,884 & 21,457 & 30,313 & 31,287 \\
\hline & \multicolumn{7}{|c|}{ (Nights spent by tourists from Croatia) } \\
\hline Hotels & 2,067 & 2,053 & 2,610 & 2,569 & 2,732 & 2,793 & 2,623 \\
\hline Pensions & 10 & 9 & 6 & 7 & 10 & 14 & 21 \\
\hline Motels & 64 & 53 & 64 & 66 & 73 & 107 & 53 \\
\hline Overnight lodging houses & 12 & 10 & 14 & 16 & 21 & 19 & 21 \\
\hline Tourist facilities & 391 & 369 & 410 & 466 & 502 & 434 & 414 \\
\hline Inns and other food and lodging establishments & 1 & 1 & 1 & 1 & 3 & 12 & 16 \\
\hline Spas and sanatoriums & 252 & 119 & 130 & 173 & 139 & 156 & 125 \\
\hline Company vacation facilities & 78 & 88 & 173 & 225 & 251 & 442 & 382 \\
\hline Vacation facilities for children and adolescents & 16 & 41 & 108 & 108 & 107 & 200 & 235 \\
\hline Campgrounds & 161 & 257 & 368 & 351 & 388 & 445 & 458 \\
\hline $\begin{array}{l}\text { Housekeeping facilities - private rooms, } \\
\text { apartments, villas and weekend cottages }\end{array}$ & 95 & 97 & 449 & 279 & 527 & 839 & 812 . \\
\hline Other & 23 & 54 & 88 & 108 & 158 & 155 & 126 \\
\hline \multirow[t]{2}{*}{ Total } & 3,170 & 3,150 & 4,421 & 4,369 & 4,911 & 5,616 & 5,286 \\
\hline & \multicolumn{7}{|c|}{ (Nights spent by foreign tourists) } \\
\hline Hotels & 2,916 & 3,676 & 5,823 & 3,018 & 5,819 & 8,454 & 8,765 \\
\hline Pensions & $\therefore 5$ & 14 & 15 & 8 & 21 & 37 & 37 \\
\hline Motels & 36 & 29 & 39 & 29 & 38 & 33 & 36 \\
\hline Overnight lodging houses & 20 & 11 & 13 & 13 & 21 & 23 & 23 \\
\hline Tourist facilities & 1,257 & 1,809 & 2,947 & 1,506 & 2,581 & 3,358 & 3,253 \\
\hline Inns and other food and lodging establishments & 1 & 1 & 1 & 1 & 2 & 27 & 50 \\
\hline Spas and sanatoriums & 48 & 80 & 153 & 88 & 33 & 51 & 41 \\
\hline Company vacation facilities & 62 & 51 & 75 & 78 & 150 & 242 & 191 \\
\hline Vacation facilities for children and adolescents & 45 & 66 & 111 & 84 & 118 & 171 & 135 \\
\hline Campgrounds $\quad \therefore$ & 2,490 & 3,305 & 4,711 & 3,078 & 5,427 & 7,412 & 8,192 \\
\hline $\begin{array}{l}\text { Housekeeping facilities - private rooms, } \\
\text { apartments, villas and weekend cottages }\end{array}$ & 614 & 651 & 1,605 & 561 & 2,279 & 4,820 & 5,208 \\
\hline Other & 61 & 65 & 63 & 51 & 57 & 69 & 71 \\
\hline Total & 7,555 & 9,758 & 15,556 & 8,515 & 16,546 & 24,697 & 26,002 \\
\hline
\end{tabular}

Source: Central Bureau of Statistics. 
Table 25. Croatia: Nights Spent by Tourists According to Country of Origin, 1992-98

\begin{tabular}{|c|c|c|c|c|c|c|c|}
\hline & 1992 & 1993 & 1994 & 1995 & 1996 & 1997 & 1998 \\
\hline & \multicolumn{7}{|c|}{ (Number of nights; in thousands) } \\
\hline Total & 7,044 & 9,758 & 15,556 & 8,515 & 16,546 & 24,697 & 26,002 \\
\hline European Union & 3,642 & 5,130 & 8,027 & 4,569 & 8,987 & 13,024 & 14,141 \\
\hline Eastern Europe & 3,257 & 4,133 & 6,946 & 3,503 & 6,844 & 10,697 & 11,386 \\
\hline Other European & 36 & 338 & 397 & 297 & 443 & 743 & 245 \\
\hline \multirow[t]{2}{*}{ Non-European } & 109 & 156 & 186 & 147 & 272 & 232 & 230 \\
\hline & \multicolumn{7}{|c|}{ (In percent) } \\
\hline Total & 100.0 & 100.0 & 100.0 & 100.0 & 100.0 & 100.0 & 100.0 \\
\hline European Union & 51.7 & 52.6 & 51.6 & 53.7 & 54.3 & 52.7 & 54.4 \\
\hline Eastern Europe & 46.2 & 42.4 & 44.7 & 41.1 & 41.4 & 43.3 & 43.8 \\
\hline Other European & 0.5 & 3.5 & 2.6 & 3.5 & 2.7 & 3.0 & 0.9 \\
\hline Non-European & 1.5 & 1.6 & 1.2 & 1.7 & 1.6 & 0.9 & 0.9 \\
\hline
\end{tabular}

Source: Central Bureau of Statistics. 
Table 26. Croatia: Composition of Employment, 1996-98 1/

(In thousands)

\begin{tabular}{lrrr}
\hline & $1996^{2 /}$ & $1997^{2 /}$ & $1998^{3 /}$ \\
\hline & & & \\
Total & $1,195.1$ & $1,187.9$ & $1,271.7$ \\
A. Agriculture, hunting and forestry & 39.1 & 33.5 & 32.5 \\
B. Fishing & 1.4 & 1.2 & 3.7 \\
C. Mining and quarrying & 8.5 & 8.5 & 8.2 \\
D. Manufacturing & 306.7 & 284.5 & 305.4 \\
E. Electricity, gas and water supply & 26.5 & 26.7 & 26.9 \\
F. Construction & 65.7 & 67.2 & 96.5 \\
G. Wholesale and retail trade & 141.4 & 146.5 & 200.8 \\
H. Hotels and restaurants & 44.0 & 43.2 & 75.6 \\
I. Transport, storage and communication & 86.1 & 88.0 & 98.5 \\
J. Financial intermediation & 26.9 & 27.5 & 29.2 \\
K. Real estate, renting and business activities & 40.0 & 41.9 & 61.4 \\
L. Public administration and defense; compulsory social security & 45.0 & 44.8 & 122.6 \\
M. Education & 76.8 & 77.1 & 78.8 \\
N. Health and social work & 77.7 & 78.0 & 81.4 \\
O. Other community, social and personal service activities & 26.6 & 26.8 & 38.4 \\
P. Private households with employed persons & $\ldots$ & $\ldots$ & 5.8 \\
Q. Extra-territorial organizations and bodies & 0.0 & 0.0 & 1.8 \\
Not classified by activity 4/ & $\ldots$ & $\ldots$ & 4.2 \\
\hline
\end{tabular}

Source: Central Bureau of Statistics.

1/ Since 1996 , data have been classified according to the national classification of economic activities. Earlier data, collected according to uniform classification of economic activities, is not comparable.

2/ Excludes persons enployed in crafts and trades and free-lances, the police and defense, as well as private farmers.

$3 /$ Excludes private farmers only.

4/ Refers to the persons employed in crafts and trades and free-lances. 
Table 27. Croatia: Trends in Employment and Unemployment, 1990-98 I/

(In units, unless otherwise indicated; end of period)

\begin{tabular}{|c|c|c|c|c|c|c|}
\hline : & $\begin{array}{l}\text { Majority State- } \\
\text { owned Ent. \& } \\
\text { Pub. Sector } 2 / \\
\text { (1) }\end{array}$ & $\begin{array}{l}\text { Private } \\
\text { Sector } 3 / \\
\text { (2) }\end{array}$ & $\begin{array}{c}\text { Total } \\
\text { Employment } \\
(3)=(1)+(2)\end{array}$ & $\begin{array}{l}\text { Unemployed } \\
\text { (registered) } \\
\text { (4) }\end{array}$ & $\begin{array}{l}\text { Labor } \\
\text { Force } \\
(5)=(3)+(4)\end{array}$ & $\begin{array}{c}\text { Unemployment } \\
\text { Rate } 4 / \\
\text { (In percent) } \\
\text { (4):(5) }\end{array}$ \\
\hline 1990 & $1,670,096$ & 285,766 & $1,955,862$ & 195,466 & $2,151,328$ & 9.1 \\
\hline 1991 & $1,482,740$ & 343,650 & $1,826,390$ & 283,308 & $2,109,698$ & 13.4 \\
\hline 1992 & $1,221,333$ & 435,200 & $1,656,533$ & 261,050 & $1,917,583$ & 13.6 \\
\hline 1993 & $1,054,357$ & 586,823 & $1,641,180$ & 243,096 & $1,884,276$ & 12.9 \\
\hline 1994 & 870,787 & 716,791 & $1,587,578$ & 247,555 & $1,835,133$ & 13.5 \\
\hline 1995 & 799,665 & 738,804 & $1,538,469$ & 249,070 & $1,787,539$ & 13.9 \\
\hline $19965 /$ & 667,979 & 764,232 & $1,432,211$ & 264,124 & $1,696,335$ & 15.6 \\
\hline $19975 /$ & 644,047 & 746,383 & $1,390,430$ & 284,611 & $1,675,041$ & 17.0 \\
\hline $19985 /$ & 607,052 & 748,990 & $1,392,042$ & 292,332 & $1,683,374$ & 17.4 \\
\hline
\end{tabular}

Sources: State Institute for Macroeconomic Analysis and Forecasting; Bureau of Statistics; and Croatian Employment Office.

1/ Total employment estimates are based on employees paying pension contributions.

2/ Comprises formerly socially owned enterprise sector as well as government sector.

/ Private sector employment includes individual farmers, entrepreneurs and their employees, independent professional workers' and employees at private enterprises. From 1992 onwards, private enterprises established in the process of privatization are included.

4/ This data is based on unofficial (lower) estimates of the labor force and, therefore, differs from that shown in the basic indicators table.

5/ End-March. 
Table 28. Croatia: Trends in Total Labor Costs, 1998-99 1/

(In thousands of kunas)

\begin{tabular}{|c|c|c|c|c|c|c|}
\hline & $\begin{array}{c}\text { Gross } \\
\text { Salaries }\end{array}$ & $\begin{array}{c}\text { Net } \\
\text { Salaries }\end{array}$ & $\begin{array}{l}\text { Contributions } \\
\text { from Salaries }\end{array}$ & $\begin{array}{l}\text { Income } \\
\text { Tax }\end{array}$ & $\begin{array}{c}\text { Compensation } \\
\text { from Employment } \\
\text { and Work }\end{array}$ & $\begin{array}{c}\text { Other } \\
\text { Contributions }\end{array}$ \\
\hline \multicolumn{7}{|l|}{1998} \\
\hline Jan. & $3,164,429$ & $2,051,607$ & 721,490 & 391,332 & 177,967 & 11,297 \\
\hline Feb. & $3,195,320$ & $2,072,272$ & 728,533 & 394,515 & 188,474 & 11,407 \\
\hline Mar. & $3,199,320$ & $2,077,493$ & 729,430 & 392,331 & 223,539 & 11,421 \\
\hline Apr. & $3,300,076$ & $2,128,935$ & 752,417 & 418,724 & 230,030 & 11,781 \\
\hline May & $3,359,352$ & $2,163,644$ & 765,932 & 429,776 & 210,396 & 11,993 \\
\hline Jun. & $3,504,945$ & $2,236,662$ & 799,127 & 469,156 & 202,211 & 12,513 \\
\hline Jul. & $3,483,188$ & $2,285,840$ & 717,537 & 479,811 & 207,247 & 12,435 \\
\hline Aug. & $3,518,010$ & $2,308,299$ & 724,710 & 485,001 & 188,210 & 12,559 \\
\hline Sep. & $3,446,944$ & $2,265,621$ & 710,070 & 471,253 & 206,521 & 12,306 \\
\hline Oct. & $3,469,779$ & $2,269,571$ & 714,774 & 485,434 & 213,395 & 12,387 \\
\hline Nov. & $3,545,118$ & $2,309,132$ & 730,294 & 505,692 & 22,721 & 12,656 \\
\hline Dec. & $3,591,774$ & $2,342,731$ & 739,905 & 509,138 & 380,440 & 12,823 \\
\hline & $\vdots$ & & . & & $\cdots$ & \\
\hline \multicolumn{7}{|l|}{1999} \\
\hline Jan. & $3,416,722$ & $2,322,572$ & 703,845 & 390,305 & 159,247 & 12,198 \\
\hline Feb. & $3,331,967$ & $2,268,552$ & 686,385 & 377,030 & 169,025 & 11,895 \\
\hline Mar. & $3,301,016$ & $2,249,672$ & 680,009 & 371,335 & 191,902 & 11,785 \\
\hline Apr. & $3,446,458$ & $2,334,252$ & 709,970 & 402,236 & 185,305 & 12,304 \\
\hline May & $3,572,691$ & $2,413,320$ & 735,974 & 423,397 & 186,549 & 12,755 \\
\hline Jun. & $3,557,639$ & $2,397,365$ & 732,874 & 427,400 & 204,324 & 12,701 \\
\hline Jul. & $3,646,494$ & $2,458,320$ & 751,178 & 436,996 & 406,968 & 13,018 \\
\hline
\end{tabular}

Source: Payment Agency (ZAP).

1/ Excluding employees of the Ministry of Defense and the Ministry of Internal Affairs 
Table 29. Croatia: Trends in Average Monthly Net Wages and Salaries, 1994-99 1/

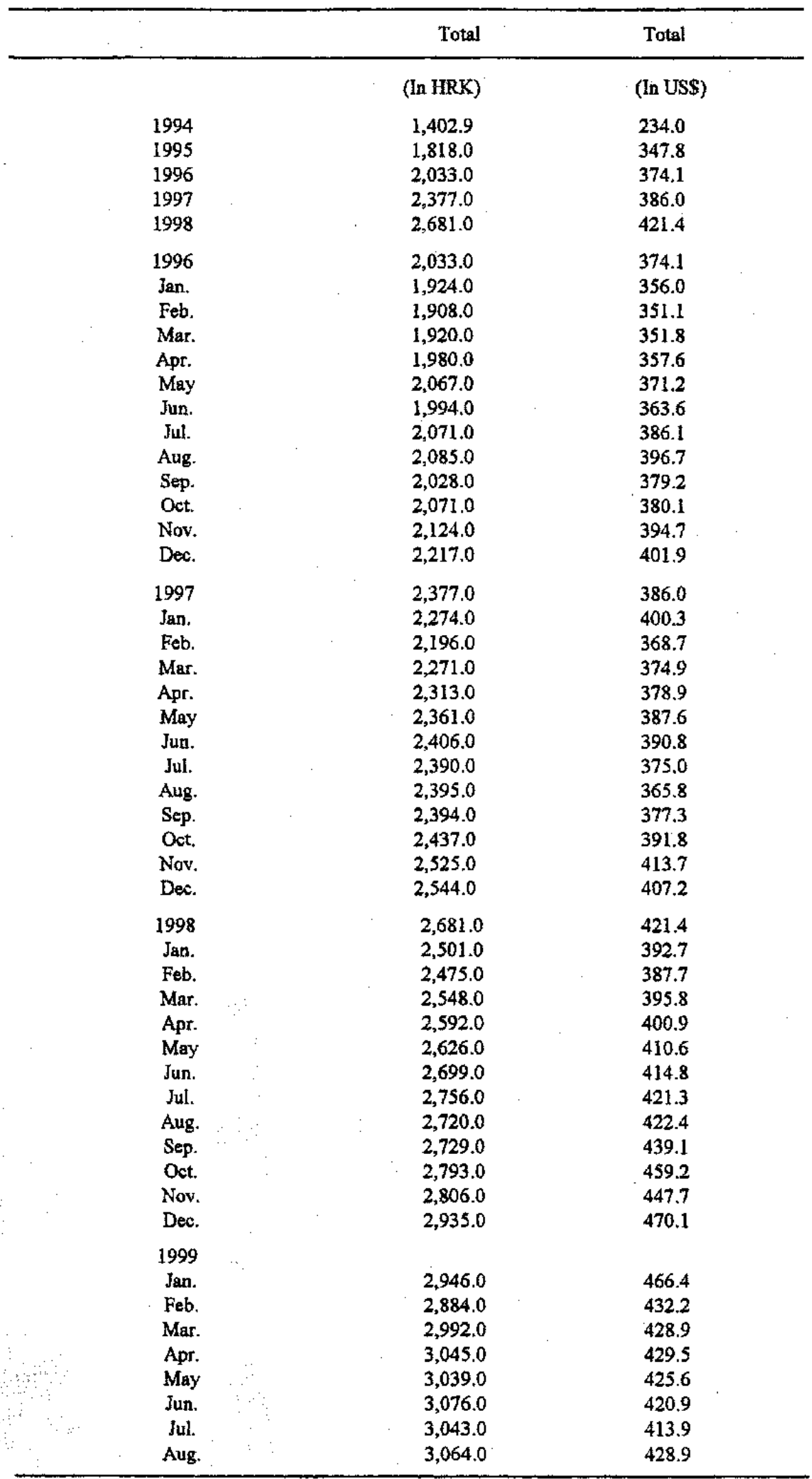

Sources: Central Bureau of Statistics; and IMF staff estimates.

$1 /$ Comprises the formerly socially owned industrial sector ("economy") and the general government sector ("non-economy"). Persons employed in the police and defense, in crafts and trades and fre-lances and private farmers are not included. 
Table 30. Croatia: Average Gross Monthly Pay Per Employee, 1996-99 1/ 2/

(In kina)

\begin{tabular}{llrrrr}
\hline & & 1996 & 1997 & 1998 & 19993 / \\
\hline Total & & & & & \\
A. & Agriculture, hunting and forestry & 3,243 & 3,668 & 4,131 & 4,476 \\
B. Fishing & 3,013 & 3,377 & 3,558 & 3,778 \\
C. & Mining and quarrying & 2,779 & 2,784 & 3,106 & 3,057 \\
D. Manufacturing & 3,838 & 4,206 & 4,351 & 4,573 \\
E. & Electricity, gas and water supply & 3,034 & 3,358 & 3,681 & 3,834 \\
F. & Construction & 3,840 & 4,148 & 4,729 & 5,105 \\
G. Wholesale and retail trade & 2,872 & 3,229 & 3,473 & 3,604 \\
H. Hotels and restaurants & 2,948 & 3,349 & 3,558 & 3,526 \\
I. Transport, storage and communication & 2,740 & 3,048 & 3,453 & 3,600 \\
J. Financial intermediation & 3,387 & 3,970 & 4,324 & 4,852 \\
K. Real estate, renting and business activities & 4,776 & 5,625 & 6,413 & 6,903 \\
L. Public administration and defense; compulsory social security & 3,659 & 4,125 & 4,643 & 4,957 \\
M. Education & 3,737 & 4,155 & 5,053 & 6,056 \\
N. Health and social work & 2,963 & 3,322 & 4,046 & 4,490 \\
O. Other community, social and personal service activities & 3,563 & 4,150 & 4,989 & 5,606 \\
P. & Private households with employed persons & 3,668 & 4,302 & 4,662 & 4,922 \\
Q. Extra-territorial organizations and bodies & $\ldots$ & $\ldots$ & $\ldots$ & $\ldots$ \\
\hline
\end{tabular}

Source: Central Bureau of Statistics.

1/ Since 1996, data have been classified according to the national classification of economic activities.

Earlier data, collected according to uniform classification of economic activities, is not comparable.

$2 /$ Excludes persons in employment in crafts and trades and free-lances, the police and defense, as well as private farmers.

3/ January-August average. 
Table 31. Croatia: Indices of Nominal Net Wages and Salaries Per Employee, 1996-99 1/2/

$(1997=100)$

\begin{tabular}{lrrrr}
\hline & 1996 & 1997 & 1998 & $19993 /$ \\
\hline Total & & & & \\
A. Agriculture, hunting and forestry & 85.5 & 100.0 & 112.8 & 126.7 \\
B. Fishing & 85.9 & 100.0 & 106.6 & 117.7 \\
C. Mining and quarrying & 94.5 & 100.0 & 116.6 & 116.0 \\
D. Manufacturing & 88.1 & 100.0 & 105.3 & 116.5 \\
E. Electricity, gas and water supply & 87.3 & 100.0 & 110.3 & 119.6 \\
F Construction & 87.7 & 100.0 & 113.1 & 127.0 \\
G. Wholesale and retail trade; repair & 87.2 & 100.0 & 109.4 & 117.9 \\
H. Hotels and restaurants & 85.4 & 100.0 & 107.4 & 113.7 \\
I. Transport, storage and communication & 86.9 & 100.0 & 113.5 & 122.1 \\
J. Financial intermediation & 83.2 & 100.0 & 109.3 & 126.9 \\
X. Real estate, renting and business activities & 82.3 & 100.0 & 113.7 & 127.5 \\
L. Public administration and defense; compulsory social security & 85.3 & 100.0 & 112.5 & 125.4 \\
M. Education & 86.7 & 100.0 & 120.2 & 146.8 \\
N. Health and social work & 85.7 & 100.0 & 120.7 & 138.9 \\
O. Other community, social and personal service activities & 83.3 & 100.0 & 119.5 & 139.2 \\
P. Private households with employed persons & 82.4 & 100.0 & 109.2 & 120.4 \\
Q. Extra-territorial organizations and bodies & $\ldots$ & $\ldots$ & $\ldots$ & $\ldots$ \\
\hline
\end{tabular}

Source: Central Bureau of Statistics.

1/ Since 1996, data have been classified according to the national classification of economic activities. Earlier data, collected according to uniform classification of economic activities, is not comparable.

2/ Excludes persons in employment in crafts and trades and free-lances, the police and defense, as well as private farmers.

3/ January-August average. 
Table 32. Croatia: Indices of Real Net Wages and Salaries Per Employee, 1996-98 1/2/

$$
(1997=100)
$$

\begin{tabular}{llrrr}
\hline & & 1996 & 1997 & 1998 \\
\hline Total & & & & \\
& & 89.0 & 100.0 & 106.0 \\
A. Agriculture, hunting and forestry & 89.4 & 100.0 & 100.2 \\
B. Fishing & 98.3 & 100.0 & 109.6 \\
C. Mining and quarrying & 91.7 & 100.0 & 98.9 \\
D. Manufacturing & 90.8 & 100.0 & 103.6 \\
E. Electricity, gas and water supply & 91.3 & 100.0 & 106.3 \\
F. Construction & 90.7 & 100.0 & 102.8 \\
G. Wholesale and retail trade; repair & 88.9 & 100.0 & 101.0 \\
H. Hotels and restaurants & 90.4 & 100.0 & 106.7 \\
I. Transport, storage and communication & 86.6 & 100.0 & 102.7 \\
J. Financial intermediation & 85.6 & 100.0 & 106.8 \\
K. Real estate, renting and business activities & 88.8 & 100.0 & 105.7 \\
L. Public administration and defense; compulsory social security & 90.2 & 100.0 & 112.9 \\
M. Education & 89.2 & 100.0 & 113.4 \\
N. Health and social work & 86.7 & 100.0 & 112.3 \\
O. Other community, social and personal service activities & 85.7 & 100.0 & 102.6 \\
P. Private households with employed persons & $\ldots$ & $\ldots$ & $\ldots$ \\
Q. Extra-territorial organizations and bodies & $\ldots$ & $\ldots$ & $\ldots$ \\
\hline
\end{tabular}

Source: Central Bureau of Statistics.

1/ Since 1996, data have been classified according to the national classification of economic activities. Earlier data, collected according to uniform classification of economic activities, is not comparable.

2/ Excludes persons in employment in crafts and trades and free-lances, the police and defense, as well as private farmers. 
Table 33. Croatia: Price Developments, 1993-99

\begin{tabular}{|c|c|c|c|c|c|c|}
\hline & \multicolumn{3}{|c|}{ Retail Prices } & \multicolumn{3}{|c|}{ Producer Prices } \\
\hline & \multirow[b]{2}{*}{$\begin{array}{c}\text { Index } \\
\text { Dec. } 1994=100\end{array}$} & \multicolumn{2}{|c|}{ Rate of Growth } & \multirow[b]{2}{*}{$\begin{array}{c}\text { Index } \\
\text { Dec. } 1994=100\end{array}$} & \multicolumn{2}{|c|}{ Rate of Growth } \\
\hline & & $\begin{array}{r}\text { Previouss } \\
\text { Period }\end{array}$ & $\begin{array}{l}\text { Same Month } \\
\text { Previous Year }\end{array}$ & & $\begin{array}{l}\text { Previous } \\
\text { Period }\end{array}$ & $\begin{array}{l}\text { Same Month } \\
\text { Previous Year }\end{array}$ \\
\hline 1993 & 50.6 & $1,516.6$ & $\ldots$ & 57.0 & $1,512.4$ & $\ldots$ \\
\hline 1994 & 100.0 & 97.6 & $\ldots$ & 101.3 & 77.6 & $\ldots$ \\
\hline 1995 & 102.0 & 2.0 & $\ldots$ & 102.0 & 0.7 & $\ldots$ \\
\hline 1996 & 105.6 & 3.5 & $\ldots$ & 103.4 & 1.4 & $\ldots$ \\
\hline 1997 & 109.4 & 3.6 & $\ldots$ & 105.8 & 2.3 & $\ldots$ \\
\hline \multicolumn{7}{|l|}{1997} \\
\hline Jan. & 108.3 & 1.0 & 4.2 & 103.6 & 0.5 & 1.8 \\
\hline Feb. & 108.3 & 0.0 & 3.7 & 103.7 & 0.1 & 2.0 \\
\hline Mar. & 108.4 & 0.1 & 3.9 & 103.0 & -0.7 & 2.2 \\
\hline Apr. & 108.5 & 0.1 & 4.4 & 103.2 & 0.0 & 1.9 \\
\hline May & 108.9 & 0.4 & 3.6 & 103.4 & 0.2 & 2.3 \\
\hline Jun. & 109.1 & 0.2 & 3.4 & 103.2 & 0.2 & 2.1 \\
\hline Jul. & 108.8 & -0.3 & 2.7 & 104.4 & -0.2 & 2.0 \\
\hline Aug. & 109.7 & 0.8 & 3.5 & 104.4 & 1.2 & 3.4 \\
\hline Sep. & 110.0 & 0.3 & 3.7 & 104.4 & 0.0 & 3.3 \\
\hline Oct. & 110.2 & 0.2 & 3.3 & 104.5 & 0.1 & 3.3 \\
\hline Nov. & 110.6 & 0.4 & 3.1 & 104.8 & 0.3 & 1.9 \\
\hline Dec. & 111.4 & 0.7 & 3.8 & 104.7 & -0.1 & 1.6 \\
\hline \multicolumn{7}{|l|}{1998} \\
\hline Jan. & 114.1 & 2.4 & 5.3 & 103.9 & -0.8 & -0.4 \\
\hline Feb. & 114.5 & 0.4 & 5.7 & 103.8 & -0.1 & -0.3 \\
\hline Mar. & 114.8 & 0.2 & 5.8 & 101.8 & -1.9 & -0.7 \\
\hline Apr. & 115.1 & 0.3 & 6.0 & 102.0 & 0.2 & -0.7 \\
\hline May & 115.7 & 0.5 & 6.0 & 101.9 & $-0,1$ & -0.6 \\
\hline Jun. & 115.7 & 0.0 & 5.8 & 102.1 & 0.2 & -0.3 \\
\hline Jul. & 115.5 & -0.2 & 5.8 & 101.8 & $-0,3$ & -0.4 \\
\hline Aug. & 115.6 & 0.1 & 5.2 & 101.7 & -0.1 & -2.3 \\
\hline Sep. & 116.6 & 0.9 & 5.8 & 101.6 & -0.1 & -2.3 \\
\hline Oct. & 117.2 & 0.5 & 6.1 & 102.0 & 0.4 & -2.1 \\
\hline Nov. & 117.4 & 0.2 & 5.9 & 102.5 & 0.5 & -2.4 \\
\hline Dec. & 117.6 & 0.2 & 5.4 & 102.5 & 0.0 & -2.1 \\
\hline \multicolumn{7}{|l|}{1999} \\
\hline Jan. & 118.2 & 0.5 & 3.4 & 102,6 & 0.1 & -0.9 \\
\hline Feb. & 118.6 & 0.3 & 3.4 & 103.4 & 0.8 & 0.0 \\
\hline Mar. & 119.1 & 0.4 & 3.5 & 102.8 & -0.6 & 1.3 \\
\hline Apr. & 119.5 & 0.3 & 3.6 & 103.4 & 0.6 & 1.7 \\
\hline May & 120.3 & 0.7 & 3.8 & 103.3 & -0.1 & 1.7 \\
\hline Jun. & 120.3 & 0.0 & 3.8 & 103.4 & 0.1 & 1.5 \\
\hline Jul. & 121.6 & 1.1 & 5.1 & 104.3 & 0.9 & 2.7 \\
\hline Aug. & 121.6 & 0.0 & 5.0 & 105.3 & 0.9 & 3.6 \\
\hline Sep. & 122.3 & 0.6 & 4.7 & 105.9 & 0.6 & 4.3 \\
\hline Oet. & 122.8 & 0.4 & 4.5 & 106.3 & 0.4 & 4.4 \\
\hline Nov. & 122.7 & -0.1 & 4.3 & 108.2 & 1.8 & 5.6 \\
\hline
\end{tabular}

Source: Central Bureau of Statistics. 
Table 34. Croatia: Retail Inflation Rates, 1992-99

(Annual average percentage change)

\begin{tabular}{|c|c|c|c|c|c|c|c|c|}
\hline & 1992 & 1993 & 1994 & 1995 & 1996 & 1997 & 1998 & 1999 l/ \\
\hline Total & 665.5 & $1,516.6$ & 97.6 & 2.0 & 3.5 & 3.6 & 5.7 & 4.1 \\
\hline Goods & 746.8 & $1,502.4$ & 95.1 & 0.0 & 2.4 & 2.8 & 4.1 & 4.1 \\
\hline Agricultural products & 623.3 & $1,135.9$ & 134.5 & 3.7 & 0.0 & 6.5 & 3.7 & -1.0 \\
\hline Industrial products - total & 751.1 & $1,514.2$ & 94.1 & -0.2 & 2.5 & 2.7 & 4.1 & 4.4 \\
\hline Processed food products & 740.7 & $1,442.2$ & 93.3 & 0.0 & 4.5 & 3.6 & 7.3 & 0.6 \\
\hline Alcoholic beverages & 749.7 & $1,593.4$ & 108.2 & 4.4 & 7.7 & 3.2 & -1.7 & 4.5 \\
\hline Tobacco & $1,050.0$ & $1,278.2$ & 159.1 & 27.2 & 18.2 & 0.0 & 0.1 & 7.5 \\
\hline Non-food industrial products & 743.3 & $1,552.6$ & 90.8 & -2.2 & 0.2 & 2.6 & 3.9 & 5.4 \\
\hline Textile products & 817.4 & $1,774.7$ & 103.5 & -4.2 & -1.5 & 5.9 & 4.5 & 9.2 \\
\hline Fuel and light & 659.9 & $1,807.1$ & 87.6 & -3.5 & 1.9 & 3.1 & 1.6 & 3.5 \\
\hline Household furnishings & 771.1 & $1,776.3$ & 103.8 & .5 .8 & -3.3 & 1.5 & -0.6 & 4.0 \\
\hline Electric appliances & 958.5 & $1,488.6$ & 62.2 & -10.6 & -3.9 & -2.2 & -0.9 & 4.1 \\
\hline Medicine & 374.7 & $2,665.1$ & 110.5 & 0.6 & -0.6 & 6.7 & 18.0 & 2.0 \\
\hline Services & 393.5 & $1,604.2$ & 110.9 & 11.9 & 8.6 & 7.0 & 12.1 & 3.8 \\
\hline Housing services & 77.0 & $1,534.4$ & 142.8 & 18.1 & 5.1 & 1.1 & 30.9 & $\ldots$ \\
\hline Public utilities and services & 358.2 & $1,805.5$ & 113.7 & 5.3 & 4.5 & 8.9 & 20.6 & $\ldots$ \\
\hline Transport & 486.7 & $1,681.4$ & 98.8 & 6.5 & 5.9 & 8.2 & 9.0 & 2.0 \\
\hline Communications & 246.2 & $1,703.8$ & 95.2 & 23.8 & 32.8 & 15.0 & 18.1 & 26.2 \\
\hline
\end{tabular}

Source: Centrai Bureau of Statistics.

1/ First eleven months over corresponding period in 1998. 
Table 35. Croatia: Employment in National Public Enterprises, 1992-98

(End of year; in units)

\begin{tabular}{|c|c|c|c|c|c|c|c|}
\hline & 1992 & 1993 & 1994 & 1995 & 1996 & 1997 & $1998 \mathrm{l} /$ \\
\hline $\begin{array}{l}\text { HRVATSKA ELEKTROPRIVREDA } \\
\text { (Electricity) }\end{array}$ & 14,250 & 13,984 & 14,457 & 14,158 & 14,664 & 15,057 & 15,665 \\
\hline $\begin{array}{l}\text { HRVATSKA VODOPRIVREDA } \\
\text { (Water Supply) }\end{array}$ & 569 & 426 & 400 & 401 & 544 & 579 & 595 \\
\hline $\begin{array}{l}\text { HRVATSKE CESTE } \\
\text { (Road Construction) }\end{array}$ & 3,857 & 3,643 & 3,715 & 3,645 & 3,752 & 3,816 & 7,804 \\
\hline $\begin{array}{l}\text { HRVATSKE ZELJEZNICE } \\
\text { (Railroads) }\end{array}$ & 29,301 & 22,840 & 22,004 & 21,812 & 21,833 & 21,966 & 19,342 \\
\hline $\begin{array}{l}\text { HPT } \\
\text { (Post and telecommunications) }\end{array}$ & 18,439 & 19,445 & 19,687 & 20,493 & 20,038 & 21,055 & 22,555 \\
\hline $\begin{array}{l}\mathrm{HP} \\
\mathrm{HT}\end{array}$ & $\ldots$ & $\begin{array}{l}\ldots \\
\ldots\end{array}$ & $\begin{array}{l}\cdots \\
\ldots\end{array}$ & $\begin{array}{l}\ldots . \\
\ldots\end{array}$ & $\begin{array}{l}\ldots \\
\ldots\end{array}$ & $\begin{array}{l}\ldots \\
\ldots\end{array}$ & $\begin{array}{r}12,584 \\
9,971\end{array}$ \\
\hline $\begin{array}{l}\text { JADROLINIJA RIJEKA } \\
\text { (Coastal navigation) }\end{array}$ & 2,209 & 1,499 & 2,113 & 1,974 & 2,046 & 2,030 & 1,489 \\
\hline $\begin{array}{l}\text { HRVATSKA RADIO - TELEVIZIJA. (HRT) } \\
\text { (Radio and TV) }\end{array}$ & 2,846 & 2,752 & 2,719 & 2,928 & 3,179 & 3,369 & 4,331 \\
\hline $\begin{array}{l}\text { HRVATSKE SUME } \\
\text { (Forestry) }\end{array}$ & 10,113 & 9,882 & 10,201 & 10,034 & 9,971 & 9,284 & 8,884 \\
\hline $\begin{array}{l}\text { NARODNE NOVINE } \\
\text { (Printing) }\end{array}$ & 725 & 763 & 746 & 727 & 701 & 652 & 526 \\
\hline $\begin{array}{l}\text { INA - INDUSTRIJA NAFTE } \\
\text { (Oil refining and distribution) }\end{array}$ & 18,345 & 18,084 & 17,965 & 17,513 & 16,525 & 13,974 & 13,406 \\
\hline Total & 100,654 & 93,318 & 94,007 & 93,685 & 93,253 & 91,782 & 94,597 \\
\hline
\end{tabular}

Sources: Central Bureau of Statistics; and State Institute for Macroeconomic Analysis and Forecasting .

1/ End-March 
Table 36. Croatia: Number of Enterprises in the Economic Sector and Number of Legal Entities Undergoing Bankruptcy, 1993-98 (End of year)

\begin{tabular}{|c|c|c|c|c|c|c|c|c|c|c|c|c|}
\hline & \multicolumn{6}{|c|}{ Number of Enterprises in the Economic Sector } & \multicolumn{6}{|c|}{ Number of Legal Entities Undergoing Bankruptcy } \\
\hline & 1993 & 1994 & 1995 & 1996 & 1997 & 1998 & 1993 & 1994 & 1995 & 1996 & 1997 & 1998 \\
\hline Total & 113,543 & 143,755 & 164,104 & 171,170 & 177,730 & 183,306 & 397 & 275 & 348 & 354 & 387 & 294 \\
\hline Total number in the Economic Sector & 84,384 & 117,775 & 135,682 & 140,719 & 145,105 & 148,247 & & & & & & \\
\hline Industry & 9,607 & 12,089 & 13,492 & 14,003 & 14,558 & 15,001 & 131 & 84 & 112 & 119 & 128 & 73 \\
\hline Agriculture and fishing & 2,380 & 3,008 & 3,349 & 3,446 & 3,520 & 3,584 & 17 & 14 & 20 & 26 & 29 & 23 \\
\hline Forestry & 90 & 124 & 151 & 159 & 173 & 177 & $\cdots$ & ... & $\cdots$ & $\cdots$ & $\cdots$ & ... \\
\hline Water supply & 35 & 34 & 36 & 35 & 36 & 39 & $\ldots$ & ... & $\cdots$ & $\ldots$ & $\cdots$ & $\cdots$ \\
\hline Construction & 5,643 & 7,723 & 9,027 & 9,643 & 10,282 & 10,819 & 64 & 45 & 55 & 51 & 56 & 34 \\
\hline Transport and communication & 2,641 & 4,158 & 4,740 & 4,998 & 5,267 & 5,465 & 2 & 4 & 6 & 7 & 8 & 10 \\
\hline Trade & 42,283 & 61,401 & 71,273 & 73,423 & 74,902 & 75,630 & 110 & 78 & 95 & 91 & 104 & 73 \\
\hline Restaurants and Tourism & 4,397 & 6,035 & 6,837 & 7,147 & 7,432 & 7,758 & 14 & 9 & 11 & 12 & 14 & 9 \\
\hline Artisanship and personal services & 3,521 & 5,029 & 5,929 & 6,086 & 6,171 & 6,212 & 24 & 15 & 18 & 17 & 17 & 9 \\
\hline Housing and urban services & 1,064 & 1,141 & 1,200 & 1,244 & 1,313 & 1,385 & 2 & 2 & 3 & 2 & 2 & 4 \\
\hline Financial, engineering and business & 12,723 & 17,033 & 19,648 & 20,535 & 21,451 & 22,177 & 33 & 24 & 28 & 28 & 28 & 39 \\
\hline Number in Non-economic Sector & 29,159 & 25,980 & 28,422 & $30,45 I$ & 32,625 & 35,059 & $\cdots$ & $\because$ & ... & $\cdots$ & $\cdots$ & \\
\hline Education and culture & 11,596 & 13,064 & 14,042 & 14,841 & 15,571 & 16,504 & $\ldots$ & $\cdots$ & $\cdots$ & $\cdots$ & $\cdots$ & 14 \\
\hline Health and social welfare & 697 & 766 & 837 & 936 & 1,044 & 1,289 & $\cdots$ & $\cdots$ & $\cdots$ & ... & $\cdots$ & 6 \\
\hline $\begin{array}{l}\text { Government, funds, associations } \\
\text { and organizations }\end{array}$ & 16,866 & 12,150 & 13,543 & 14,674 & 16,010 & 17,266 & $\cdots$ & ... & $\cdots$ & $\cdots$ & $\cdots$ & .. \\
\hline
\end{tabular}

Source: Central Bureau of Statistics. 
Table 37. Croatia: Budgetary Central Government Revenue, 1991-99.

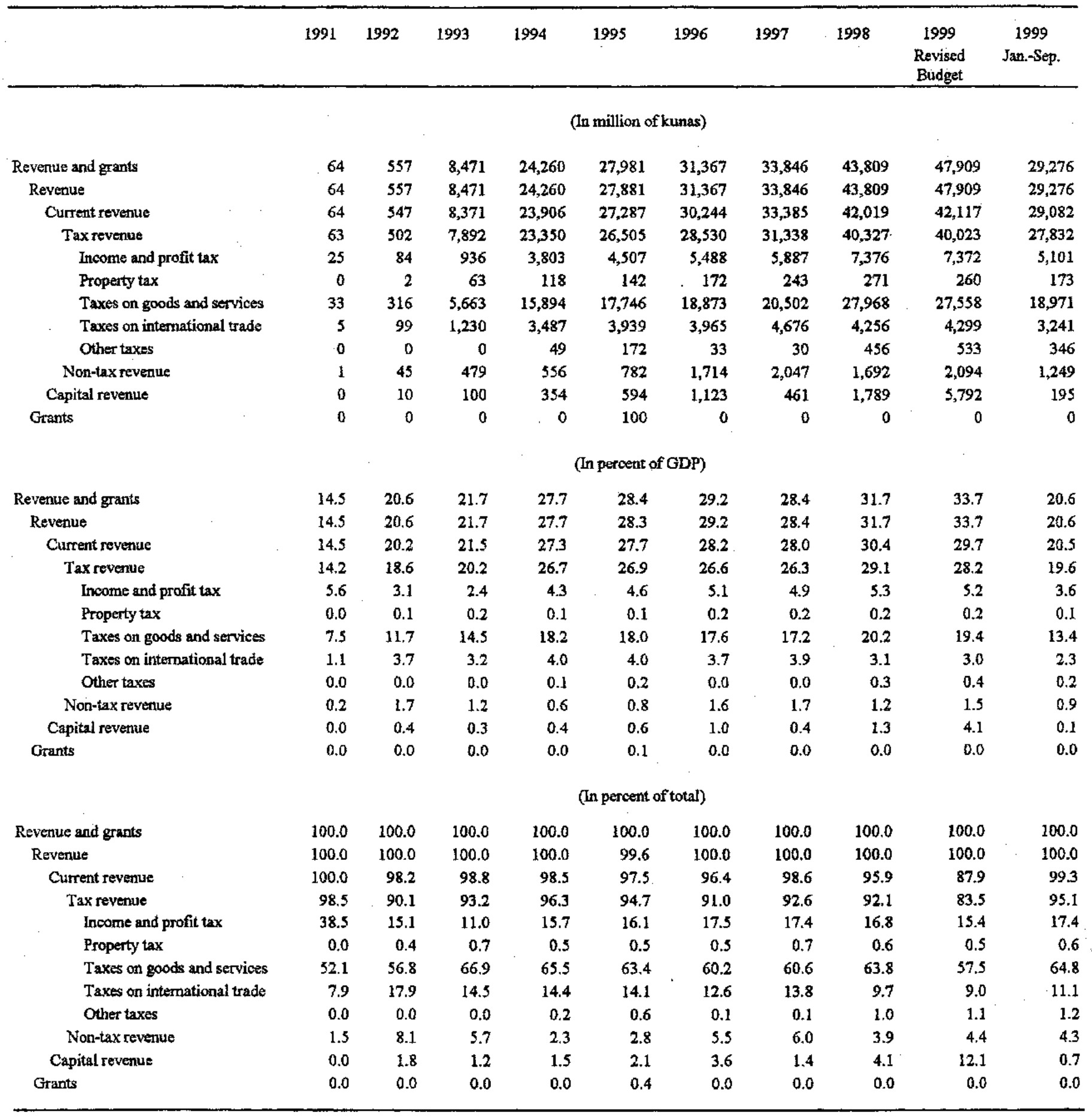

Source: Ministry of Finance. 
Table 38. Croatia: Budgetary Central Government Expenditure and Net Lending, 1992-99

\begin{tabular}{|c|c|c|c|c|c|c|c|c|c|}
\hline & 1992 & 1993 & 1994 & 1995 & 1996 & 1997 & 1998 & $\begin{array}{l}1999 \\
\text { Revised } \\
\text { Buógel }\end{array}$ & $\begin{array}{c}1999 \\
\text { Jan_-Sep. }\end{array}$ \\
\hline & \multicolumn{9}{|c|}{ (In millions of kuna) } \\
\hline Expenditure and net lending & 564 & 8,403 & 23,546 & 28,696 & 31,502 & 35,006 & 42,552 & 49,334 & 33,172 \\
\hline Expenditure & 564 & 8,403 & 23,230 & 28,476 & 30,973 & 34,395 & 41,473 & 48,223 & 32,284 \\
\hline Current expenditure : & 520 & 7,742 & 20,745 & 25,495 & 25,930 & 29,580 & 34,883 & 38,180 & 27,125 \\
\hline Expenditure on goods and services & 396 & 6,111 & 17,144 & 20,735 & 19,623 & 20,263 & 22,649 & 22,510 & 15,689 \\
\hline Wages and salaries & 98 & 1,941 & 6,589 & 8,394 & 8,365 & 9,148 & 10,852 & 12,013 & 8,840 \\
\hline Employer contributions & 24 & 484 & 1,383 & 1,716 & 1,966 & 1,892 & 2,179 & 2,577 & 1,837 \\
\hline Other goods and services & 273 & 3,686 & 9,173 & 10,625 & 9,292 & 9,223 & 9,618 & 7,920 & 5,012 \\
\hline Interest payments & 21 & 212 & 1,131 & 1,392 & 1,218 & 1,737 & 1,951 & 2,214 & 1,589 \\
\hline Domestic & 21 & 207 & 895 & 911 & 950 & 775 & 917 & 986 & 671 \\
\hline External & 0 & 5 & 236 & 481 & 268 & 962 & 1,034 & 1,228 & 918 \\
\hline Subsidies and other current transfers & 103 & 1,419 & 2,470 & 3,369 & 5,089 & 7,579 & 10,283 & 13,455 & 9,847 \\
\hline Capital expenditure & 44 & 661 & 2,485 & 2,980 & 5,043 & 4,815 & 6,590 & 10,044 & $\$, 160$ \\
\hline \multirow[t]{2}{*}{ Lending minus repayments } & 0 & 0 & 316 & 221 & 529 & 611 & 1,079 & 1,111 & 887 \\
\hline & \multicolumn{9}{|c|}{ (In percent of GDP) } \\
\hline Expenditure and net lending & 20.8 & 21.5 & 26.9 & 29.2 & 29.4 & 29.3 & 30.7 & 34.7 & 23.4 \\
\hline Expenditure & 20.8 & 21.5 & 26.6 & 28.9 & 28.9 & 28.8 & 30.0 & 34.0 & 22.7 \\
\hline Current expenditure & 19.2 & 19.8 & 23.7 & 25.9 & 24.2 & 24.8 & 25.2 & 26.9 & 19.1 \\
\hline Expenditure on goods and services & 14.6 & 15.7 & 19.6 & 21.1 & 18.3 & 37.0 & 16.4 & 15.9 & 11.0 \\
\hline Wages and salaries & 3.6 & 5.0 & 7.5 & 8.5 & 7.8 & 7.7 & 7.8 & 8.5 & 6.2 \\
\hline Employer contributions & 0.9 & 1.2 & 1.6 & 1.7 & 1.8 & 1.6 & 1.6 & 1.8 & 1.3 \\
\hline Other goods and services & 10.1 & 9.5 & 10.5 & 10.8 & 8.7 & 7.7 & 7.0 & 5.6 & 3.5 \\
\hline Interest payments & 0.8 & 0.5 & 1.3 & 1.4 & 1.1 & 1.5 & 1.4 & 1.6 & 1.1 \\
\hline Domestic & 0.8 & 0.5 & 1.0 & 0.9 & 0.9 & 0.6 & 0.7 & 0.7 & 0.5 \\
\hline External & 0.0 & 0.0 & 0.3 & 0.5 & 0.2 & 0.8 & 0.7 & 0.9 & 0.6 \\
\hline Subsidies and other current transfers & 3.8 & 3.6 & 2.8 & 3.4 & 4.7 & 6.4 & 7.4 & 9.5 & 6.9 \\
\hline Capital expenditure & 1.6 & 1.7 & 2.8 & 3.0 & 4.7 & 4.0 & 4.8 & 7.1 & 3.6 \\
\hline \multirow[t]{2}{*}{ Lending minus repayments } & 0.0 & 0.0 & 0.4 & 0.2 & 0.5 & 0.5 & 0.8 & 0.8 & 0.6 \\
\hline & \multicolumn{9}{|c|}{ (In percent of total) } \\
\hline Expenditure and net lending & 100.0 & 100.0 & 100.0 & 100.0 & 100.0 & 100.0 & 100.0 & 100.0 & 100.0 \\
\hline Expenditure & 100.0 & 100.0 & 98.7 & 99.2 & 98.3 & 98.3 & 97.5 & 97.7 & 97.3 \\
\hline Current expenditure & 92.1 & 92.1 & 88.1 & 88.8 & 82.3 & 84.5 & 82.0 & 77.4 & 81.8 \\
\hline Expenditure on goods and services & 70.1 & 72.7 & 72.8 & 72.3 & 62.3 & 57.9 & 53.2 & 45.6 & 47.3 \\
\hline Wages and salaries & 17.4 & 23.1 & 28.0 & 29.2 & 26.6 & 26.1 & 25.5 & 24.3 & 26.6 \\
\hline Employer contributions & 4.3 & 5.8 & 5.9 & 6.0 & 6.2 & 5.4 & 5.1 & 5.2 & 5.5 \\
\hline Other goods and services & 48.4 & 43.9 & 39.0 & 37.0 & 29.5 & 26.3 & 22.6 & 16.1 & 15.1 \\
\hline Interest payments & 3.7 & 2.5 & 4.8 & 4.9 & 3.9 & 5.0 & 4.6 & 4.5 & 4.8 \\
\hline Domestic & 3.7 & 2.5 & 3.8 & 3.2 & 3.0 & 2.2 & 2.2 & 2.0 & 2.0 \\
\hline External & 0.0 & 0.1 & 1.0 & 1.7 & 0.8 & 2.7 & 2.4 & 2.5 & 2.8 \\
\hline Subsidies and other current transfers & 18.3 & 16.9 & 10,5 & 11.7 & 16.2 & 21.7 & 24.2 & 27.3 & 29.7 \\
\hline Capital expenditure & 7.9 & 7.9 & 10.6 & 10.4 & 16.0 & 13.8 & 15.5 & 20.4 & 15.6 \\
\hline Lending minus repayments & 0.0 & 0.0 & 1.3 & 0.8 & 1.7 & 1.7 & 2.5 & 2.3 & 2.7 \\
\hline
\end{tabular}

Source: Ministry of Finance. 
Table 39. Croatia: Budgetary Central Government Expenditure by Function, 1991-99

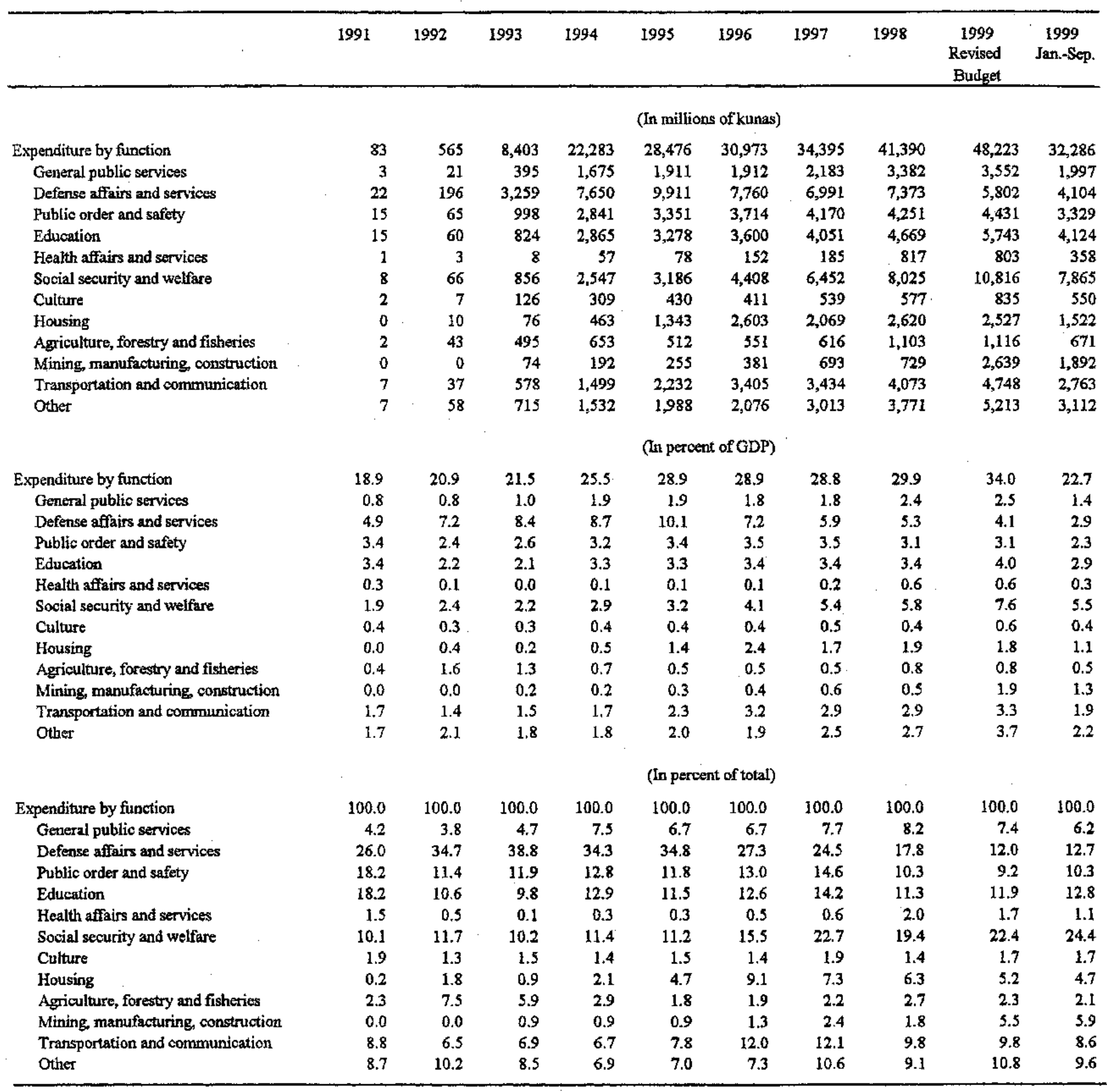

Source: Ministry of Finance. 
Table 40. Croatia: Consolidated Central Government Fiscal Accounts, 1991-99

\begin{tabular}{|c|c|c|c|c|c|c|c|c|c|c|}
\hline & 1991 & 1992 & 1993 & 1994 & 1995 & 1996 & 1997 & 1998 & $\begin{array}{l}1999 \\
\text { Revised } \\
\text { Budget }\end{array}$ & $\begin{array}{c}1999 \\
\text { Jan-Sep. }\end{array}$ \\
\hline & \multicolumn{8}{|c|}{ (In millions of kuna) } & & \\
\hline \multicolumn{11}{|l|}{ Central budgetary government $1 / 2^{\prime}$} \\
\hline Revenues and grants & 64 & 557 & 8,471 & 24,260 & $27,48 \mathrm{I}$ & 30,731 & 33,665 & 43,809 & 47,909 & 29,276 \\
\hline Expenditures plus net lending & 70 & 500 & 7,482 & 21,939 & 26,189 & 27,592 & 29,409 & 34,125 & 36,178 & 23,924 \\
\hline Balance & -6 & 57 & 989 & 2,321 & 1,292 & 3,139 & 4,255 & 9,683 & 11,730 & 5,353 \\
\hline \multicolumn{11}{|l|}{ Extrabudgetary funds $1 / 3$ / } \\
\hline Revenues and grants & 75 & 315 & 4,849 & 12,622 & 15,898 & 17,940 & 19,986 & 21,302 & 21,656 & 15,542 \\
\hline Expenditures plus net lending & 90 & 477 & 6,163 & 13,529 & 18,062 & 21,556 & 25,827 & 30,103 & 34,852 & 24,808 \\
\hline Balance & -15 & -162 & $-1,314$ & -907 & $-2,164$ & $-3,617$ & $-5,841$ & $-8,801$ & $-13,196$ & $-9,266$ \\
\hline \multicolumn{11}{|l|}{ Consolidated central government $1 /$} \\
\hline Revenues and grants & 139 & 872 & 13,320 & 36,882 & 43,379 & 48,671 & 53,651 & 65,111 & 69,555 & 44,818 \\
\hline Expenditures plus net lending & 160 & 977 & 13,645 & 35,469 & 44,251 & 49,148 & 55,236 & 64,229 & 71,030 & 48,732 \\
\hline Balance & -21 & -105 & -326 & 1,413 & -872 & -477 & $-1,586$ & 882 & $-1,475$ & $-3,913$ \\
\hline & \multicolumn{10}{|c|}{ (In percent of GDP) } \\
\hline \multicolumn{11}{|l|}{ Central government $1 / 2 f$} \\
\hline Revenues and grants & 14.5 & 20.6 & 21.7 & 27.7 & 27.9 & 28.7 & 28.2 & 31.7 & 33.7 & 20.6 \\
\hline Expenditures plus net lending & 15.9 & 18.5 & 19.2 & 25.1 & 26.6 & 25.7 & 24.6 & 24.7 & 25.5 & 16.8 \\
\hline Balance & -1.4 & 2.1 & 2.5 & 2.7 & 1.3 & 2.9 & 3.6 & 7.0 & 8.3 & 3.8 \\
\hline \multicolumn{11}{|l|}{ Extrabudgetary funds $1 / 3 /$} \\
\hline Revenues and grants & 17.0 & 11.6 & 12.4 & 14.4 & 16.2 & 16.7 & 16.7 & 15.4 & 15.3 & 10.9 \\
\hline Expenditures plus net lending & 20.3 & 17.6 & 15.8 & 15.5 & 18.4 & 20.1 & 21.6 & 21.8 & 24.5 & 17.5 \\
\hline Balance & .3 .3 & -6.0 & -3.4 & -1.0 & -2.2 & -3.4 & -4.9 & -6.4 & -9.3 & -6.5 \\
\hline \multicolumn{11}{|l|}{ Consolidated central government $1 /$} \\
\hline Revenues and grants & 31.5 & 32.2 & 34.2 & 42.2 & 44.1 & 45.4 & 45.0 & 47.0 & 49.0 & 31.6 \\
\hline Expenditures plus net lending & 36.2 & 36.1 & 35.0 & 40.6 & 45.0 & 45.8 & 46.3 & 46.4 & 50.0 & 34.3 \\
\hline Balance & -4.7 & -3.9 & -0.8 & 1.6 & -0.9 & -0.4 & -1.3 & 0.6 & -1.0 & -2.8 \\
\hline
\end{tabular}

Sources: Ministry of Finance; and IMF staff estimates.

1/ Revenues and expenditures adjusted for intra-governmental transfers.

2/ Includes since 1994 the Crostian Roads Fund.

3/ Composed of the Pension Fund, Health Fund, Employment Fund, Child Benefits Fund, and Public Water Management Fund. 
Table 41. Croatia: Outstanding Stocks of Domestic Debt of the Central Budgetary Government, 1991-99

(In millions of deutsche marks at current exchange rates, end of period)

\begin{tabular}{|c|c|c|c|c|c|c|c|c|c|}
\hline & 1991 & 1992 & 1993 & 1994 & 1995 & 1996 & 1997 & 1998 & $\begin{array}{r}1999 \\
\text { October }\end{array}$ \\
\hline $\begin{array}{l}\text { Medium- and long-term credits from } \\
\text { the Croatian National Bank (CNB) }\end{array}$ & 0.0 & 31.3 & 4.1 & 4.3 & 104.1 & 57.9 & 3.1 & 0.0 & 0.0 \\
\hline CNB loan I & 0.0 & 31.3 & 4.1 & 4.3 & 3.8 & 3.5 & 3.1 & 0.0 & 0.0 \\
\hline CNB loan III & 0.0 & 0.0 & 0.0 & 0.0 & 100.3 & 54.4 & 0.0 & 0.0 & 0.0 \\
\hline Frozen foreign exchange deposits (ffcd) & $5,033,9$ & $4,653.6$ & $3,989.7$ & $3,245.9$ & $2,796.3$ & $2,382.8$ & $2,102.4$ & $1,718.0$ & $1,447.0$ \\
\hline Bonds 1993 (interest ffed) & 0.0 & 0.0 & 107.4 & 89.5 & 53.7 & 17.9 & 0.0 & 0.0 & 0.0 \\
\hline Bonds 1994-1 (interest ffcd) & 0.0 & 0.0 & 0.0 & 47.6 & 0.0 & 0.0 & 0.0 & 0.0 & 0.0 \\
\hline Bonds $1994-2$ (interest ffcd) & 0.0 & 0.0 & 0.0 & 0.0 & 9.7 & 0.0 & 0.0 & 0.0 & 0.0 \\
\hline Bonds JDA 1995-1 (principal ffcd) & 0.0 & 0.0 & 0.0 & 0.0 & 153.7 & 128.1 & 76.9 & 25.6 & 0.0 \\
\hline Bonds JDB 1995,1996 (principal ffed) & 0.0 & 0.0 & 0.0 & 0.0 & 0.0 & 147.1 & 98.1 & 49.0 & 0.0 \\
\hline "Big Bonds" - Series I & $1,550.1$ & $1,597.3$ & $1,420.0$ & $1,360.7$ & $1,301.4$ & 445.1 & 415.4 & 391.3 & 334.6 \\
\hline "Big Bonds" - Series II (Rijecka \& Splitska) & 0.0 & 0.0 & 0.0 & 0.0 & 0.0 & 220.0 & 211.4 & 199.5 & 192.5 \\
\hline "Big Bonds" - Series III (Privredna) & 0.0 & 0.0 & 0.0 & 0.0 & 0.0 & 209.0 & 205.1 & 196.9 & 188.3 \\
\hline "Big Bonds" - Series IV (Privredna Banka) & 0.0 & 0.0 & 0.0 & 0.0 & 0.0 & 213.4 & 182.8 & 116.0 & 40.9 \\
\hline BRA bonds - Series I (Rujecka \& Splitska) & 0.0 & 0.0 & 0.0 & 0.0 & 0.0 & 313.1 & 267.0 & 284.6 & 272.6 \\
\hline BRA bonds - Series II (Privredna Banka) & 0.0 & 0.0 & 0.0 & 0.0 & 0.0 & 86,4 & 84.5 & 80.4 & 76.1 \\
\hline BRA bonds - Series III (Privredna Banka) & 0.0 & 0.0 & 0.0 & 0.0 & 0.0 & 216.5 & 212.5 & 199.8 & 190.7 \\
\hline BRA bonds - Series IV (Privredna Banka) & 0.0 & 0.0 & 0.0 & 0.0 & 0.0 & 120.6 & 118.0 & 110.1 & 104.2 \\
\hline BRA bonds - Series VA (Dubrovacka Banka) & 0.0 & 0.0 & 0.0 & 0.0 & 0.0 & 0.0 & 0.0 & 134.1 & 113.4 \\
\hline BRA bonds - Series VB (Dubrovacka Banka) & 0.0 & 0.0 & 0.0 & 0.0 & 0.0 & 0.0 & 0.0 & 0.0 & 409,6 \\
\hline Reconstraction bonds & 0.0 & 0.0 & 16.3 & 10.9 & 8.0 & 7.3 & 5.5 & 6.1 & 5.8 \\
\hline Depreciation Ioan & 0.0 & 0.0 & 0.0 & 278.5 & 185.7 & 95.7 & 0.0 & 0.0 & 0.0 \\
\hline Apartment bonds & 0.0 & 0.0 & 0.0 & 0.0 & 0.0 & 245.0 & 196.0 & $\cdots$ & $\cdots$ \\
\hline Treasury bills & 0.0 & 0.0 & 0.0 & 0.0 & 0.0 & 76.4 & 105.7 & 151.3 & 197.6 \\
\hline Totsl & $6,584.0$ & $6,282.2$ & $5,537.4$ & $5,037.4$ & $4,612.5$ & $4,982.1$ & $4,284.1$ & $3,662.7$ & $3,573.3$ \\
\hline
\end{tabular}

Source: Ministry of Finance. 
Table 42. Croatia: Government Employment, 1992-97

(End of period)

\begin{tabular}{|c|c|c|c|c|c|c|}
\hline & 1992 & 1993 & 1994 & 1995 & 1996 & 1997 \\
\hline & \multicolumn{6}{|c|}{ (In units) } \\
\hline Central government & 25,635 & 27,055 & 26,190 & 24,688 & 25,231 & 26,963 \\
\hline Budgetary central government & 18,885 & 14,753 & 13,892 & 17,590 & 18,169 & 19,981 \\
\hline Administration & 6,938 & 8,471 & 7,823 & 10,691 & 11,214 & 11,580 \\
\hline Legislature & 721 & 852 & 817 & 1,099 & 1,150 & 1,193 \\
\hline Judiciary & 5,725 & 5,430 & 5,252 & 5,800 & 5,805 & 5,931 \\
\hline Social Accounting Service (ZAP) & 5,501 & 5,430 & 5,252 & 5,252 & 5,200 & $\cdots$ \\
\hline Croatian National Bank (CNB) & 384 & 401 & 431 & 460 & 460 & $\ldots$ \\
\hline Extrabudgetary funds & 6,366 & 6,471 & 6,615 & 6,638 & 6,602 & 6,982 \\
\hline Regional and local governments & 20,443 & 19,395 & 25,560 & 18,948 & 19,000 & 19,637 \\
\hline Health care & 73,158 & 73,409 & 69,996 & 71,234 & 71,317 & 66,792 \\
\hline Social services & 24,090 & 24,613 & 24,978 & 25,578 & 25,097 & 23,682 \\
\hline Education & 64,489 & 67,328 & 65,860 & 67,284 & 66,187 & 66,285 \\
\hline Primary & 38,202 & 39,449 & 38,910 & 39,197 & 38,341 & 37,503 \\
\hline Secondary & 17,249 & 18,354 & 17,922 & 18,574 & 18,149 & 18,410 \\
\hline Tertiary & 8,280 & 8,420 & 8,374 & 8,607 & 8,690 & 8,746 \\
\hline Other & 758 & 1,105 & 654 & 906 & 1,007 & 1,626 \\
\hline Research & 3,994 & 3,947 & 3,865 & 3,990 & 3,361 & 3,536 \\
\hline Culture, arts and information & 17,048 & 16,576 & 16,446 & 16,619 & 17,093 & 18,757 \\
\hline Sports & 1,608 & 1,578 & 1,513 & 1,536 & 1,458 & 1,556 \\
\hline \multirow[t]{2}{*}{ Total general government } & 230,465 & 234,285 & 234,954 & 237,310 & 231,083 & $234,178 \quad 1 /$ \\
\hline & \multicolumn{6}{|c|}{ (In percent of total employment) } \\
\hline Total general government & 18.3 & 18.9 & 19.4 & 19.8 & 19.3 & 19.7 \\
\hline Budgetary central government & 1.5 & 1.2 & 1.1 & 1.5 & 1.5 & 1.7 \\
\hline Regional and local governments & 1.6 & 1.6 & 2.1 & 1.6 & 1.6 & 1.7 \\
\hline Extrabudgetary funds & 0.5 & 0.5 & 0.5 & 0.6 & 0.6 & 0.6 \\
\hline \multicolumn{7}{|l|}{ Providers of } \\
\hline Health care & 3.7 & 3.8 & 3.7 & 6.0 & 6.0 & 5.6 \\
\hline Education & 3.3 & 3.5 & 3.5 & 5.6 & 5.5 & 5.6 \\
\hline Social services & 1.2 & 1.3 & 1.3 & 2.1 & 2.1 & 2.0 \\
\hline Culture, arts and information & 0.9 & 0.9 & 0.9 & 1.4 & 1.4 & 1.6 \\
\hline
\end{tabular}

Source: Croatian Ministry of Finance.

1/ Excluding ZAP and the $\mathrm{CNB}$. 
Table 43. Croatia: Health Insurance, 1992-98

(Number of persons insured; annual averages)

\begin{tabular}{lcccccccc}
\hline & 1992 & 1993 & 1994 & 1995 & 1996 & 1997 & 1998 & \\
& & & & & & & & \\
& $4,608,466$ & $4,571,955$ & $4,591,341$ & $4,629,280$ & $4,634,634$ & $4,634,142$ & $4,075,226$ \\
Total & $1,606,984$ & $1,573,520$ & $1,564,494$ & $1,588,344$ & $1,599,226$ & $1,604,895$ & $1,430,649$ \\
Currently employed 1/ & 712,032 & 742,828 & 778,400 & 799,892 & 821,909 & 850,052 & 931,169 \\
Pensioners & 178,618 & 166,534 & 161,660 & 158,164 & 174,123 & 189,844 & 192,148 \\
Unernployed persons & $1,847,566$ & $1,818,717$ & $1,813,077$ & $1,811,602$ & $1,824,209$ & $1,824,144$ & $1,319,571$ \\
Family members & 191,000 & 191,000 & 191,000 & 191,649 & 138,088 & 80,585 & 28,243 \\
Refugees and displaced persons & 72,266 & 79,356 & 82,710 & 79,629 & 77,079 & 84,652 & 173,446 \\
\hline
\end{tabular}

Sources: CBS, Statistical Year Book; and Croatian Health Insurance Institute.

1/ Ircluding active farmers. 
Table 44. Croatia: Disability and Retirement Insurance, 1992-98

\begin{tabular}{|c|c|c|c|c|c|c|c|}
\hline & 1992 & 1993 & 1994 & 1995 & 1996 & 1997 & 1998 \\
\hline & \multicolumn{7}{|c|}{ (Number of persons) } \\
\hline Retirement benefits & 762,072 & 784,364 & 813,382 & 863,551 & 874,061 & 907,479 & 938,647 \\
\hline Disabilty pensions & 183,530 & 181,614 & 184,989 & 193,654 & 197,049 & 207,858 & 212,753 \\
\hline Old-age pensions & 387,405 & 409,122 & 433,180 & 443,688 & 451,046 & 467,363 & 487,431 \\
\hline Survivor pensions & 191,137 & 193,628 & 195,213 & 200,589 & 196,603 & 202,866 & 212,709 \\
\hline Former republies of former Yugoslavia & & & 25,620 & 29,118 & 29,363 & 29,392 & 26,354 \\
\hline $\begin{array}{l}\text { Disability compensation } \\
\text { (for bodily injury) }\end{array}$ & 95,153 & 100,964 & 104,172 & 104,819 & 105,392 & 105,919 & 107,093 \\
\hline $\begin{array}{l}\text { Disabled workers - retraining } \\
\text { or additional training }\end{array}$ & 2,472 & 2,159 & 2,102 & 2,476 & 953 & 651 & 444 \\
\hline \multicolumn{8}{|l|}{ Disabled workers - } \\
\hline unemployment benefits & 7,418 & 11,654 & 13,061 & 14,434 & 21,016 & 37,699 & 39,688 \\
\hline \multicolumn{8}{|l|}{ Compensation for less than } \\
\hline full-time ernployment & 16,947 & 16,192 & 16,145 & 14,390 & 11,811 & 12,028 & 6,876 \\
\hline \multicolumn{8}{|l|}{ Compensation for reduced } \\
\hline \multirow[t]{2}{*}{ pay on new jab } & 32,043 & 31,637 & 32,956 & 32,217 & 28,335 & 25,823 & 23,103 \\
\hline & \multicolumn{7}{|c|}{ (Expenditures, in thousands of kuras) } \\
\hline Total & 208,836 & $3,318,269$ & $8,479,06 \mathrm{I}$ & $10,667,302$ & $12,343,273$ & $15,448,078$ & $16,535,589$ \\
\hline Disability pensions & 39,383 & 593,397 & $1,245,613$ & $1,648,754$ & $1,969,763$ & $2,944,078$ & $3,341,432$ \\
\hline Old-age pensions & 108,681 & $1,756,203$ & $3,698,375$ & $4,412,054$ & $4,758,209$ & $6,648,471$ & $7,493,421$ \\
\hline Survivor pensions & 36,132 & 571,993 & $1,208,417$ & $1,510,676$ & $1,672,647$ & $2,434,623$ & 290,444 \\
\hline Supplement (100 kuna) & ... & $\ldots$ & 413,087 & $\$ 21,767$ & $1,059,389$ & $\ldots$ & ... \\
\hline Compensation for bodily injury & 1,382 & 20,709 & 42,780 & 51,695 & $\$ 7,350$ & 82,959 & 81,431 \\
\hline $\begin{array}{l}\text { Costs and compensations associated } \\
\text { with retraining and additional }\end{array}$ & & & & & & & 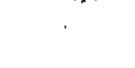 \\
\hline training of disabled workers & 4,471 & 96,256 & 240,043 & 257,632 & 351,947 & 640,939 & 789,832 \\
\hline Contributions to housing construction & 2,754 & 36,128 & 3,243 & $1,782,484$ & $1,924,702$ & $1,721,989$ & 344,452 \\
\hline Administrative costs & 4,933 & 91,481 & 166,327 & 316,078 & 222,901 & 250,774 & 328,785 \\
\hline Other & 11,100 & 152,102 & $1,874,265$ & 274,842 & 326365 & 724,245 & $1,251,782$ \\
\hline
\end{tabular}

Sources: Central Bureau of Statistics, and National Wonkers' Retirement and Disability Fund. 
Table 45. Croatia: Accounts of the Health Fund, 1994-99

(In millions of kuna)

\begin{tabular}{|c|c|c|c|c|c|c|c|}
\hline & 1994 & 1995 & 1996 & 1997 & 1998 & $\begin{array}{c}1999 \\
\text { Revised } \\
\text { Budget }\end{array}$ & $\begin{array}{c}1999 \\
\text { Jan-Sep }\end{array}$ \\
\hline Revenue and grants & 5,942 & 7,602 & 8,751 & 9,343 & 11,552 & 12,964 & 8,972 \\
\hline Current revenue & 5,819 & 7,253 & 8,134 & 8,536 & 9,915 & 10,378 & 7,503 \\
\hline \multicolumn{8}{|l|}{ Social security contribution } \\
\hline (including transfers from Pension Fund) & 5,553 & 6,960 & 7,779 & 8,418 & 9,783 & 10,185 & 7,352 \\
\hline Nontax revenue & 266 & 293 & 355 & 118 & 132 & 192 & 150 \\
\hline Capital revenue & 0 & 0 & 0 & 25 & 76 & 0 & 0 \\
\hline Grants (current transf. from the government) & 122 & 349 & 617 & 782 & 1,561 & 2,586 & 1,469 \\
\hline Expenditure and net lending & 5,636 & 7,592 & 8,924 & 9,434 & 11,571 & 12,964 & 9,055 \\
\hline Current expenditure & 5,636 & 7,528 & 8,737 & 9,176 & 11,401 & 12,834 & 8,959 \\
\hline Wages and salaries & 1,810 & 2,580 & 2,807 & 3,353 & 3,858 & 4,221 & 3,099 \\
\hline Employer contributions & 380 & 510 & 567 & 691 & 795 & 863 & 638 \\
\hline Other purchases of goods and services & 2,790 & 3,308 & 3,729 & 3,168 & 4,671 & 5,490 & 3,816 \\
\hline Interest & 0 & 0 & 0 & 15 & 12 & 19 & 10 \\
\hline Transfers to households & 655 & 1130 & 1634 & 1949 & 2,065 & 2,241 & 1,396 \\
\hline Capital expenditure (aquis. of fixed capital assets) & 0 & 64 & 187 & 258 & 170 & 130 & 96 \\
\hline Net lending & 0 & 0 & 0 & 0 & 0 & 0 & 0 \\
\hline Current balance excluding grants & 184 & -275 & -602 & -640 & $-1,486$ & $-2,456$ & $-1,456$ \\
\hline Overall balance & 306 & 10 & -173 & -91 & -19 & 0 & -83 \\
\hline Financing & -306 & -10 & 173 & 91 & 19 & 0 & 83 \\
\hline Foreign & 0 & 0 & 84 & 71 & 37 & 0 & 3 \\
\hline Domestic & -306 & -10 & 89 & 20 & -19 & 0 & 80 \\
\hline Of which : From depasit money banks & -306 & -10 & 89 & 20 & -19 & 0 & 80 \\
\hline
\end{tabular}

Sources: Ministry of Finance; and IMF staff estimates. 
Table 46. Croatia: Accounts of the Pension and Disability Insurance Fund, 1991-99

(In millions of kuna)

\begin{tabular}{|c|c|c|c|c|c|c|c|c|c|c|}
\hline & 1991 & 1992 & 1993 & 1994 & 1995 & 1996 & 1997 & 1998 & $\begin{array}{c}1999 \\
\text { Revised } \\
\text { Budget }\end{array}$ & $\begin{array}{l}1999 \\
\text { Jan.-Sep. }\end{array}$ \\
\hline Revenue and grants & 46 & 188 & 3,008 & 8,325 & 10,524 & 12,407 & 15,300 & 16,137 & 19,348 & 14,107 \\
\hline Current revenue & 43 & 185 & 2,968 & 8,322 & 10,030 & 11,106 & 12,439 & 11,907 & 12,968 & 9,229 \\
\hline Social security contributions & 42 & 170 & 2,636 & 8,041 & 9,807 & 10,951 & 12,244 & 11,767 & 12,897 & 9,181 \\
\hline Other nontax revenue (mostly property income) & 1 & 15 & 332 & 281 & 223 & 155 & 196 & 140 & 72 & 48 \\
\hline Capital revenue (sales of shares) & 0 & 0 & 0 & 0 & 162 & 141 & 236 & 431 & 150 & 79 \\
\hline Grants (transfer from the budget) & 2 & 3 & 40 & $\mathbf{3}$ & 332 & 1,160 & 2,624 & 3,799 & 6,229 & 4,799 \\
\hline Expenditure and net lending & 46 & 209 & 3,318 & 8,002 & 10,667 & 12,411 & 15,548 & 16,555 & 19,348 & 14,108 \\
\hline Current expenditure & 46 & 209 & 3,318 & 8,002 & 10,651 & 12,394 & 15,533 & 16,521 & 19,318 & 14,102 \\
\hline Wages and salaries & 1 & 3 & 46 & 99 & 133 & 143 & 164 & 223 & 253 & 184 \\
\hline Employer contributions & 0 & 0 & 10 & 22 & 24 & 27 & 31 & 42 & 52 & 35 \\
\hline Other purchases of goods and services & 3 & 13 & 184 & 258 & 321 & 258 & 340 & 328 & 399 & 289 \\
\hline Interest & 0 & 0 & 0 & 4 & 2 & 1 & 14 & 28 & 23 & 42 \\
\hline Transfer to the Health Fund $1 /$ & 0 & 0 & 0 & 1,295 & 1,782 & 1,925 & 1,722 & 344 & 0 & 0 \\
\hline Persion payments & 42 & 193 & 3,078 & 6,324 & 8,389 & 10,040 & 13,263 & 15,500 & 18,532 & 13,551 \\
\hline Capital expenditure & 0 & 0 & 0 & 0 & 16 & 18 & 15 & 34 & 30 & 6 \\
\hline Net lending & 0 & 0 & 0 & 0 & 0 & 0 & 0 & 0 & 0 & 0 \\
\hline Current balance excluding grants & -2 & -24 & -351 & 320 & -621 & $-1,288$ & $-3,093$ & $-4,614$ & $-6,349$ & $-4,872$ \\
\hline Overall balance & 0 & -21 & .310 & 323 & -143 & -4 & -248 & -418 & 0 & -1 \\
\hline Financing & 0 & 21 & 310 & -323 & 143 & 4 & 248 & 418 & 0 & 1 \\
\hline Foreign & 0 & 0 & 0 & 0 & 0 & 0 & 0 & 0 & 0 & 0 \\
\hline Domestic & 0 & 21 & 310 & -323 & 143 & 4 & 248 & 418 & 0 & 1 \\
\hline \multicolumn{11}{|l|}{ Memorandum itens: } \\
\hline $\begin{array}{l}\text { Rate of contribution to the Pension Fund } \\
\text { (end of period) } 2 /\end{array}$ & 22.0 & 22.0 & 22.0 & 27.0 & 25.5 & 25.5 & 25.5 & 21.5 & 21.5 & 21.5 \\
\hline Total expenditure on pensions in percent of GDP & 9.6 & 7.1 & 7.9 & 7.2 & 8.5 & 9.4 & 11.1 & 11.2 & 13.1 & 9.5 \\
\hline
\end{tabular}

Sources: Ministry of Finance; and Central Bureau of Statistics.

1/ Transfer to pay for health care for pensioners. The contribution to the Health Fund was reduced from 25 percent to 18 percent of pension payments in January 1997 and eliminated altogether in February 1998. To compensate for the elimination of this transfer to the Health Fund, the contribution rate to the Pension Fund was reduced from 25.5 percent to 21.5 percent, and the contribution rate to the Health Fund increased from 14 percent to 18 percent, with both changes also becoming effective in February 1998 .

$2 /$ In percent of gross wages. Includes both employers' and workers' contributions. 
Table 47. Croatia: Key Indicators of the Pension System, 1991-98

\begin{tabular}{|c|c|c|c|c|c|c|c|c|}
\hline & 1991 & 1992 & 1993 & 1994 & 1995 & 1996 & 1997 & 1998 \\
\hline Total number of pensioners (end-of-period) & 646,140 & 762,072 & 784,364 & 813,382 & 863,551 & 874,061 & 907,479 & 919,409 \\
\hline Of which: Old-age pensioners & 310,068 & 387,405 & 409,122 & 433,180 & 443,688 & 451,046 & 467,363 & 496,714 \\
\hline Total active insured persons (end-of-period) & $1,839,265$ & $1,724,792$ & $1,698,138$ & $1,644,009$ & $1,567,981$ & $1,478,975$ & $1,468,938$ & $1,471,509$ \\
\hline Of which: Workers' Fund & $1,555,734$ & $1,442,406$ & $1,410,638$ & $1,354,146$ & $1,340,951$ & $1,267,650$ & $1,270,226$ & $1,282,576$ \\
\hline Dependency ratio (insured/pensioners) $1 /$ & 2.4 & 1.9 & 1.8 & 1.7 & 1.6 & 1.5 & 1.4 & 1.4 \\
\hline Old-age dependency ratio $2 /$ & 2.9 & 2.8 & 2.8 & 2.7 & 2.7 & 2.7 & 2.7 & 2.7 \\
\hline $\begin{array}{l}\text { Average old-age monthly pension } \\
\text { (period average; in kunas) }\end{array}$ & 6 & 25 & 376 & 755 & 924 & 994 & 1,154 & 1,314 \\
\hline Net replacement rate for old-age pensions $3 /$ & 74.2 & 73.6 & 71.4 & 60.6 & 50.8 & 48.9 & 48.6 & 49.0 \\
\hline
\end{tabular}

Sources: Central Bureau of Statistics; Croatian Pension and Disability Fund; and the World Bank.

1/ Insured persons of the Workers' Fund only.

2/ Population between 20 and 59 years old over population aged 60 or more.

3/ Average monthly old-age pension over average monthly net wage. 
Table 48. Croatia: Consolidated General Government, 1994-98

\begin{tabular}{|c|c|c|c|c|c|c|c|c|c|c|}
\hline & $\begin{array}{c}1994 \\
\text { Actual }\end{array}$ & $\begin{array}{c}1995 \\
\text { Actual }\end{array}$ & $\begin{array}{c}1996 \\
\text { Actual }\end{array}$ & $\begin{array}{c}1997 \\
\text { Actual }\end{array}$ & $\begin{array}{c}1998 \\
\text { Actual }\end{array}$ & $\begin{array}{c}1994 \\
\text { Actual }\end{array}$ & $\begin{array}{c}1995 \\
\text { Actual }\end{array}$ & $\begin{array}{c}1996 \\
\text { Actual }\end{array}$ & $\begin{array}{c}1997 \\
\text { Actual }\end{array}$ & $\begin{array}{c}1998 \\
\text { Actual }\end{array}$ \\
\hline & \multicolumn{5}{|c|}{ (ln millions of kuna) } & \multicolumn{5}{|c|}{ (Percent of GDP) } \\
\hline Revenue and grants & 40,325 & 47,440 & 54,385 & 60,200 & 72,738 & 46.1 & 48.2 & 50.4 & 48.6 & 52.6 \\
\hline Revenue & 40,325 & 47,430 & 54,371 & 60,182 & 72,687 & 46.1 & 48.2 & 50.4 & 48.6 & 52.5 \\
\hline Current revenue & 39,965 & 46,451 & 52,779 & 58,987 & 69,947 & 45.7 & 47.2 & 48.9 & 47.6 & 50.5 \\
\hline Tax revenue & 37,898 & 43,677 & 47,962 & 53,282 & 64,506 & 43.3 & 44.4 & 44.4 & 43.0 & 46.6 \\
\hline Income and profit tax including social security contributions & 17,728 & 21,053 & 24,222 & 26,943 & 30,743 & 20.3 & 21.4 & 22.4 & 21.8 & 22.2 \\
\hline Personal Income tax & 5,317 & 5,732 & 6,916 & 6,714 & 8,051 & 6.1 & 5.8 & 6.4 & 5.4 & 5.8 \\
\hline Social security contributions & 11,525 & 13,920 & 15,534 & 17,725 & 19,215 & 13.2 & 14.1 & 14.4 & 14.3 & 13.9 \\
\hline Profits tax & 887 & 1,401 & 1,772 & 2,504 & 3,477 & 1.0 & 1.4 & 1.6 & 2.0 & 2.5 \\
\hline Property tax & 306 & 476 & 551 & 748 & 810 & 0.3 & 0.5 & 0.5 & 0.6 & 0.6 \\
\hline Donestic taxes on goods and services & 15,797 & 17,763 & 18,895 & 20,538 & 27,968 & 18.1 & 18.1 & 17.5 & 16.6 & 20.2 \\
\hline General sales, or VAT & 13,107 & 12,802 & 13,504 & 15,133 & 22,200 & 15.0 & 13.0 & 12.5 & 12.2 & 16.0 \\
\hline Excises & 2,689 & 4,960 & 5,391 & 5,405 & 5,768 & 3.1 & 5.0 & 5.0 & 4.4 & 4.2 \\
\hline Local taxes on goods and services & 348 & 114 & 116 & 146 & 145 & 0.4 & 0.1 & 0.1 & 0.1 & 0.1 \\
\hline Taxes on international trade & 3,487 & 3,922 & 3,942 & 4,640 & 4,256 & 4.0 & 4.0 & 3.7 & 3.7 & 3.1 \\
\hline Other tax revenue & 233 & 350 & 236 & 267 & 582 & 0.3 & 0.4 & 0.2 & 0.2 & 0.4 \\
\hline Non-tax revernue & 2,066 & 2,774 & 4,816 & 5,704 & 5,441 & 2.4 & 2.8 & 4.5 & 4.6 & 3.9 \\
\hline Capital revenuse & 361 & 979 & 1,593 & 1,195 & 2,740 & 0.4 & 1.0 & 1.5 & 1.0 & 2.0 \\
\hline Privatization & 359 & 965 & 1,553 & 1,155 & 2,704 & 0.4 & 1.0 & 1.4 & 0.9 & 2.0 \\
\hline Capital Transfers from nongovernment sources & 2 & 14 & 40 & 40 & 36 & 0.0 & 0.0 & 0.0 & 0.0 & 0.0 \\
\hline Grants & 0 & 10 & 14 & 18 & 51 & 0.0 & 0.0 & 0.0 & 0.0 & 0.0 \\
\hline Expenditure and net lending & 38,598 & 48,140 & 54,785 & 61,697 & 72,059 & 44.1 & 48.9 & 50.7 & 49.8 & 52.1 \\
\hline Expenditure & 38,274 & 47,882 & 54,297 & 61,058 & 70,871 & 43.8 & 48.7 & 50.3 & 49.3 & 51.2 \\
\hline Current expenditure & 35,607 & 43,409 & 46,941 & 53,608 & 61,342 & 40.7 & 44.1 & 43.5 & 43.3 & 44.3 \\
\hline Expenditure on goods and services & 22,669 & 27,370 & 27,160 & 28,667 & 33,985 & 25.9 & 27.8 & 25.2 & 23.2 & 24.6 \\
\hline Wages aud salaries & 9,064 & 11,739 & 12,051 & 13,577 & 16,350 & 10.4 & 11.9 & 11.2 & 11.0 & 11.8 \\
\hline Other goods and services & 13,606 & 15,630 & 15,109 & 15,089 & 17,635 & 15.6 & 15.9 & 14.0 & 12.2 & 12.7 \\
\hline Interest payments & 1,138 & 1,423 & 1,243 & 1,839 & 2,104 & 1.3 & 1.4 & 1.2 & 1.5 & 1.5 \\
\hline Domestic & 966 & 942 & 976 & 876 & 1,068 & 1.1 & 1.0 & 0.9 & 0.7 & 0.8 \\
\hline External & 173 & 481 & 268 & 962 & 1,036 & 0.2 & 0.5 & 0.2 & 0.8 & 0.7 \\
\hline Subsidies and other current transfers & 11,799 & 14,616 & 18,537 & 23,103 & 25,252 & 13.5 & 14.9 & 17.2 & 18.7 & 18.2 \\
\hline Capital expenditure & 2,667 & 4,473 & 7,356 & 7,450 & 9,530 & 3.1 & 4.5 & 6.8 & 6.0 & 6.9 \\
\hline Lending minus repayments & 324 & 258 & 487 & 639 & 1,188 & 0.4 & 0.3 & 0.5 & 0.5 & 0.9 \\
\hline Current balance & 4,227 & 3,042 & 5,838 & 5,379 & 8,605 & 4.8 & 3.1 & 5.4 & 4.3 & 6.2 \\
\hline Overall balance & 1,596 & -700 & -399 & $-1,497$ & 678 & 1.8 & -0.7 & -0.4 & -1.2 & 0.5 \\
\hline less privatization & 1,238 & $-1,665$ & $-1,952$ & $-2,652$ & $-2,026$ & 1.4 & -1.7 & -1.8 & -2.1 & -1.5 \\
\hline Primary balance & 2,735 & 723 & 844 & 342 & 2,783 & 3.1 & 0.7 & 0.8 & 0.3 & 2.0 \\
\hline less privalization & 2,376 & -242 & -709 & -813 & 78 & 2.7 & -0.2 & -0.7 & -0.7 & 0.1 \\
\hline
\end{tabular}

Source: Ministry of Finance Annual Report 1994-1998. 
Table 49. Croatia: Monetary Survey, 1994-99

(In millions of kuna; end of period)

\begin{tabular}{|c|c|c|c|c|c|c|c|c|c|c|c|}
\hline & \multirow[b]{2}{*}{1994} & \multirow[b]{2}{*}{1995} & \multirow[b]{2}{*}{1996} & \multirow[b]{2}{*}{1997} & \multicolumn{4}{|c|}{1998} & \multicolumn{3}{|c|}{199911} \\
\hline & & & & & Mar. & June & Sep. & Dec. & Mar. & June & Sep. \\
\hline \multicolumn{12}{|l|}{ Assets } \\
\hline 1. Foreign assets (net) & $1,139.8$ & $3,046.7$ & $11,740.7$ & $16,913.0$ & $14,619.5$ & $14,885.5$ & $15,260.0$ & $12,713.5$ & $10,616.5$ & $12,046.1$ & $14,361.8$ \\
\hline 2. Domestic credit & $43,280.5$ & $47,976.6$ & $48,464.9$ & $56,194.9$ & $58,993.4$ & $62,302.7$ & $64,324.1$ & $66,923.1$ & $69,126.1$ & $64,190.7$ & $66,598.3$ \\
\hline 2.1. Claims on central government and funds (net) & $15,619.0$ & $15,157.1$ & $14,633.7$ & $7,331.4$ & $6,229.3$ & $6,397.4$ & $6,520.1$ & $7,131.1$ & $9,064.8$ & $9,219.3$ & $8,544.5$ \\
\hline 2.2. Claims on other domestic sectors & $27,599.5$ & $32,718.6$ & $33,691.0$ & $48,616.6$ & $52,516.6$ & $55,609.1$ & $57,503.5$ & $59,597.7$ & $59,866.6$ & $54,807.9$ & $57,862.0$ \\
\hline 2.3. Claims on other banking institutions & 0.0 & 0.0 & 0.0 & 0.0 & 0.0 & 0.0 & 0.0 & 0.0 & 0.4 & 0.0 & 47.1 \\
\hline 2.4. Claims on other financial institutions & 62.1 & 100.8 & 140.2 & 246.8 & 247.4 & 296.2 & 300.5 & 193.9 & 194.3 & 163.5 & 144.6 \\
\hline Total $(1+2)$ & $44,420.3$ & $51,023.3$ & $60,205,6$ & $73,107.8$ & $73,612.9$ & $77,188.2$ & $79,584.1$ & $79,636.5$ & $79,742.6$ & $76,236.8$ & $80,960.1$ \\
\hline \multicolumn{12}{|l|}{ Liabilities } \\
\hline 1. Money & $6,642.6$ & $8,234.9$ & $11,368.9$ & $13,731.4$ & $12,758.0$ & $13,309.4$ & $13,852.3$ & $13,531.4$ & $11,982.4$ & $13,269.5$ & $13,559.4$ \\
\hline 2. Savings and time deposits & $2,045.6$ & $2,158.0$ & $3,386.6$ & $5,598.9$ & $5,890.2$ & $5,552.6$ & $5,943.6$ & $5,683.8$ & $5,353.1$ & $4,977.2$ & $5,252.5$ \\
\hline 3. Foreign currency deposits & $8,783.3$ & $14,099.4$ & $21,817.5$ & $31,278.1$ & $33,453.0$ & $34,958.5$ & $37,046.0$ & $37,970.9$ & $39,165.5$ & $34,970.5$ & $35,994.6$ \\
\hline 4. Bonds and money market instruments & 208.5 & 130.7 & 128.1 & 133.6 & 136.5 & 127.4 & 123.9 & 154.1 & 134.5 & 138.0 & 510.7 \\
\hline 5. Restricted and blocked deposits & $12,128.6$ & $10,717.4$ & $8,305.4$ & $5,953.4$ & $5,192,0$ & $5,069.6$ & $4,538.6$ & $4,315.2$ & $4,598.2$ & $4,375.0$ & $3,886.4$ \\
\hline \multicolumn{12}{|l|}{ Of which } \\
\hline Households' blocked ffc deposits & $11,470.6$ & $9,812.5$ & $7,170.6$ & $4,573.8$ & $4,158.3$ & $3,951.7$ & $3,445.9$ & $3,419.1$ & $3,184.1$ & $3,110.5$ & $2,798.7$ \\
\hline 6. Other items (net) & $14,611.8$ & $15,682: 8$ & $15,199.2$ & $16,412.5$ & $16,183.1$ & $18,170.7$ & $18,079.7$ & $17,981.1$ & $18,509.0$ & $18,506.6$ & $21,756.6$ \\
\hline Total $(1+2+3+4+5+6)$ & $44,420.3$ & $51,023.3$ & $60,205.6$ & $73,107.8$ & $73,612.9$ & $77,188.2$ & $79,584,1$ & $79,636.5$ & $79,742.6$ & $76,236.8$ & $80,960.1$ \\
\hline \multicolumn{12}{|l|}{ Memorandum items: } \\
\hline 1. Net domestic assets & $16,540.1$ & $21,576.3$ & $24,960.4$ & $33,829.0$ & $37,618.3$ & $39,062.4$ & $41,705.8$ & $44,626.8$ & $46,018.9$ & $41,309.2$ & $40,955.3$ \\
\hline \multicolumn{12}{|l|}{ Assets } \\
\hline 1. Claims on central government and funds (net) & $15,619.0$ & $15,157.1$ & $14,633.7$ & $7,331.4$ & $6,229.3$ & $6,397.4$ & $6,520.1$ & $7,131.1$ & $9,064.8$ & $9,219.3$ & $8,544.5$ \\
\hline 2. Domestic credit & $27,661.5$ & $32,819.5$ & $33,831.2$ & $48,863.4$ & $52,764.0$ & $55,905.3$ & $57,804.0$ & $59,791.6$ & $60,061.2$ & $54,971.4$ & $58,053.8$ \\
\hline 3. Other assets (net) & $-26,740.4$ & $-26,400.3$ & $-23,504.6$ & $-22,365.9$ & $-21,375.1$ & $-23,240.3$ & $-22,618.3$ & $-22,295.9$ & $-23,107.2$ & $-22,881.5$ & $-25,643.0$ \\
\hline \multicolumn{12}{|l|}{ Liabilities } \\
\hline 1. Broadest money (M4) & $17,679.9$ & $24,623.0$ & $36,701.1$ & $50,742.0$ & $52,237.8$ & $53,947.9$ & $56,965.8$ & $57,340.3$ & $56,635.4$ & $53,355.2$ & $55,317.1$ \\
\hline 2. Foreign liabilities (net) & $-1,139.8$ & $-3,046.7$ & $-11,740.7$ & $-16,913.0$ & $-14,619.5$ & $-14,885.5$ & $-15,260.0$ & $-12,713.5$ & $-10,616.5$ & $-12,046.1$ & $-14,361.8$ \\
\hline
\end{tabular}

Source: Croatian National Bank.

1/ Data from Q2 1999 onwards excludes the assets and liabilities of the banks declared bankrupt in April 1999. Changes in the statistical reporting system introduced a break in the data in July 1999. 
Table 50. Croatia: Money Authorities' Balance Sheet, 1994-99

(In millions of kuna; end of period)

\begin{tabular}{|c|c|c|c|c|c|c|c|c|c|c|c|}
\hline & \multirow[b]{2}{*}{1994} & \multirow[b]{2}{*}{1995} & \multirow[b]{2}{*}{1996} & \multirow[b]{2}{*}{1997} & \multicolumn{4}{|c|}{1998} & \multicolumn{3}{|c|}{1999} \\
\hline & & & & & Mar. & June & Sept. & Dec. & Mar. & June & Sept. \\
\hline \multicolumn{12}{|l|}{ Assets } \\
\hline 1. Foreign assets & $7,908.3$ & $10,075.1$ & $12,818.5$ & $16,004,9$ & $15,952.9$ & $16,829.5$ & $17,016.1$ & $17,591.5$ & $17,375,2$ & $19,156.5$ & $20,412.9$ \\
\hline 2. Claims on central government and funds & 250.6 & 390.1 & 218.8 & 0.0 & 0.0 & 0.0 & 617.1 & 0.0 & $1,270.0$ & $1,374.4$ & $1,378.0$ \\
\hline 3. Claims on other domestic sectors $1 /$ & 0.7 & 0.9 & 1.1 & 24.4 & 0.3 & 2.3 & 1.7 & 1.0 & 0.4 & 303.6 & 291.6 \\
\hline 4. Claims on banks $2 /$ & 223.8 & 220.2 & 213.9 & 33.5 & 314.9 & 487.1 & 666.7 & $1,053.8$ & $1,638.0$ & $1,309.4$ & $1,609.5$ \\
\hline 5. Claims on other banking institutions $2 /$ & 0.0 & 0.0 & 0.0 & 0.0 & 0.0 & 0.0 & 0.0 & 0.0 & 0.0 & 0.0 & 0.0 \\
\hline Total $(1+2+3+4+5)$ & $8,383.4$ & $10,686.3$ & $13,252.3$ & $16,062.8$ & $16,268.1$ & $17,318.8$ & $18,301.6$ & $18,646.2$ & $20,283.6$ & $22,143.9$ & $23,692.0$ \\
\hline \multicolumn{12}{|l|}{ Liabilities } \\
\hline 1. Reserve money & $4,714.2$ & $6,744.1$ & $8,770.4$ & $10,346.1$ & $9,520.8$ & $9,742.1$ & $10,373.8$ & $9,954.2$ & $8,966.1$ & $9,493.9$ & $9,906.7$ \\
\hline 1.1 Currency outside banks $2 /$ & $2,657.3$ & $3,362.1$ & $4,361.3$ & $5,307.5$ & $4,985.3$ & $5,244.8$ & $5,579.4$ & $5,718.8$ & $5,029.7$ & $5,608.4$ & $5,533.5$ \\
\hline 1.2 Banks' cash 2/ & 134.7 & 134.5 & $\lfloor 52.2$ & 216.9 & 176.4 & 207.8 & 222.6 & 251.4 & 207.6 & 245.9 & 260.3 \\
\hline 1.3 Banks' deposits $2 /$ & $1,906.6$ & $3,244.7$ & $4,256.7$ & $4,821.6$ & $4,358.4$ & $4,279.7$ & $4,569.6$ & $3,980.2$ & $3,726.5$ & $3,637.1$ & $4,110.5$ \\
\hline 1.4 Deposits of other banking institutions $2 /$ & 0.0 & 0.0 & 0.0 & 0.0 & 0.0 & 0.0 & 0.0 & 2.4 & 1.5 & 1.7 & 1.8 \\
\hline 1.5 Deposits of other domestic sectors & 15.6 & 2.8 & 0.1 & 0.0 & 0.7 & 9.8 & 2.1 & 1.3 & 0.8 & 0.8 & 0.6 \\
\hline 2. Restricted and blocked deposits & 40.3 & 212.2 & 243.2 & $10 t .1$ & 108.6 & 118.1 & 560.9 & $1,787.6$ & $3,523.2$ & $4,275.9$ & 4,837.1 \\
\hline 2.1 Restricted deposits $3 /$ & 40.3 & 54.1 & 78.7 & 101.1 & 108.6 & 118.1 & 125.8 & 119.1 & 141.5 & 336.2 & 359.1 \\
\hline 2.2 Blocked f/c deposits & 0.0 & 158.1 & 164.4 & 0.0 & 0.0 & 0.0 & 0.0 & 0.0 & 0,0 & 0.0 & 0.0 \\
\hline 3. Foreign liabilities & 716.1 & $1,175.1$ & $1,160.0$ & $1,470.7$ & $1,486.3$ & 1,4919 & $1,422.6$ & $1,464.3$ & $1,588.2$ & $1,548,3$ & $1,571.7$ \\
\hline 4. Central govemment and funds' deposits & 793.8 & 395.5 & 557.6 & $1,032.7$ & $1,618.2$ & $1,339.0$ & $1,024.5$ & 434.8 & 530.5 & 600.0 & 467.6 \\
\hline 4.1 Demand deposits & 793.8 & 395.5 & 424.6 & 805.7 & $1,340.5$ & $1,170.5$ & 955.1 & 390.2 & 495.8 & 580.2 & 467.6 \\
\hline 4.2 Foreign currency deposits & 0.0 & 0.0 & 0.0 & 147.6 & 0.0 & 0.0 & 0.0 & 0.0 & 0.0 & 0.0 & 0.0 \\
\hline 4.3 CNB bills & 0.0 & 0.0 & 133.0 & 79.4 & 277.7 & 168.5 & 69.4 & 44.6 & 34.7 & 19.8 & 0.0 \\
\hline 5. CNB bills & 375.1 & 168.3 & 665.7 & 722.0 & 936.5 & $1,708.7$ & $2,303.4$ & $2,242.9$ & $1,906.4$ & $2,306.1$ & $2,720.2$ \\
\hline 6. Other items (net) & $1,743.8$ & $1,991.1$ & $1,855.4$ & $2,390.2$ & $2,597.6$ & $2,919.1$ & $2,616.4$ & $2,762.4$ & $3,769.3$ & $3,919.7$ & $4,188.7$ \\
\hline Total $(1+2+3+4+5+6)$ & $8,383.4$ & $10,686.3$ & $13,252.3$ & $16,062.8$ & $16,268.1$ & $17,318.8$ & $18,301.6$ & $18,646.2$ & $20,283.6$ & $22,143.9$ & $23,692.0$ \\
\hline
\end{tabular}

Source: Croatian National Bank.

1/ After May 1999, includes overdue claims on banks for which bankruptcy proceedings have been initiated.

2/ Data revised due to the reclassification of savings banks from the subsector other banking institutions to the subsector banks.

3/ After May 1999, includes depasits of banks for which bankruptcy proceedings have been initiated. 
Table 51. Croatia: Deposit Money Banks' Accounts, 1994-99

(In million of kuna; end of period)

\begin{tabular}{|c|c|c|c|c|c|c|c|c|c|c|c|}
\hline & \multirow[b]{2}{*}{1994} & \multirow[b]{2}{*}{1995} & \multirow[b]{2}{*}{1996} & \multirow[b]{2}{*}{1997} & \multicolumn{4}{|c|}{1998} & \multicolumn{3}{|c|}{1999} \\
\hline & & & & & Mar. & June & Sep. & Dec. & Mar. & June $1 /$ & Sep. $2 /$ \\
\hline \multicolumn{12}{|l|}{ Assets } \\
\hline 1. Reserves & $2,033.5$ & $3,302.1$ & $4,359.2$ & $4,963.3$ & $4,548.4$ & $4,501.5$ & $5,238.4$ & $5,908.1$ & $7,325.4$ & $7,844.8$ & $8,854.6$ \\
\hline 2. Foreign assets & $7,078.4$ & $9,273.9$ & $12,518.0$ & $16,126.7$ & $16,426.0$ & $15,468.9$ & $15,575.9$ & $12,763.1$ & $11,740.9$ & $10,821.6$ & $12,113.8$ \\
\hline 3. Clains on central government & $17,837.0$ & $17,186.5$ & $16,692.7$ & $15,238.7$ & $14,816.9$ & $15,010.9$ & $14,493.5$ & $14,864.2$ & $16,571.6$ & $16,590.9$ & $15,876.3$ \\
\hline 3.1 Bonds arising from blocked $/ / \mathrm{c}$ deposits & $11,437.3$ & $10,078.2$ & $8,291.1$ & $6,714.3$ & $6,367.3$ & $6,237.1$ & $5,642.4$ & $5,802.3$ & $5,562.5$ & $5,404.1$ & $5,515,6$ \\
\hline 3.2 Big bonds & $4,971.6$ & $5,060.9$ & $2,438.5$ & $2,291.9$ & $2,182.6$ & $2,186.9$ & $2,125.5$ & $2,103.1$ & $2,088.8$ & $2,055.6$ & $1,702.7$ \\
\hline 3.3 Other claims & $1,428.1$ & $2,047.4$ & $5,963.1$ & $6,232.5$ & $6,267.0$ & $6,586.9$ & $6,725.5$ & $6,958.8$ & $8,920.2$ & $9,131,1$ & $8,657.9$ \\
\hline 4. Clains on other domestic sectors & $27,220.8$ & $32,345.8$ & $33,310.0$ & $47,926.1$ & $52,516.3$ & $55,606.8$ & $57,501.8$ & $59,596.7$ & $59,866.2$ & $54,504.3$ & $57,570.5$ \\
\hline 4.1 Claims on local government & 112.9 & 147.1 & 145.4 & 308.8 & 383.0 & 565.3 & 570.5 & 654.0 & 731.9 & 763.3 & 869.4 \\
\hline 4.2 Claims on enterprises & $23,733.5$ & $27,686.4$ & $26,814.7$ & $35,282.8$ & $37,887.1$ & $39,410.3$ & $40,091,4$ & $41,225.5$ & $40,742.9$ & $35,684.8$ & $37,808.8$ \\
\hline 4.3 Claims on households & $3,374.4$ & $4,512.3$ & $6,349.9$ & $12,334.5$ & $14,246.2$ & $15,631.2$ & $16,839.9$ & $17,717.2$ & $18,391.4$ & $18,056.2$ & $18,892.3$ \\
\hline 5. Claims on other barking institutions & 30.0 & 30.8 & 38.4 & 72.9 & $\ldots$ & $\ldots$ & $\cdots$ & 0.4 & 0.4 & - & 47.1 \\
\hline 6. Claims on other financial institutions & 61.8 & 100.6 & $139 . \mathrm{I}$ & 240.9 & 247.4 & 296.2 & 300.5 & 193.9 & 194.3 & 163.5 & 144.6 \\
\hline Total $(1+2+3+4+5+6)$ & $54,261.4$ & $62,239.8$ & $67,057.4$ & $84,568.5$ & $88,555.0$ & $90,884.4$ & $93,110.1$ & $93,326.4$ & $95,698,7$ & $89,925.1$ & $94,606.9$ \\
\hline \multicolumn{12}{|l|}{ Liabilities } \\
\hline 1. Demand deposits & $3,960.5$ & $4,861.2$ & $6,997.2$ & $8,404.8$ & $7,772.0$ & $8,054.8$ & $8,270.7$ & $7,808.9$ & $6,950.4$ & $7,658.6$ & $8,023.5$ \\
\hline 2. Savings and time deposits & $1,866.9$ & $2,037.9$ & $3,254.7$ & $5,350.8$ & $5,890.2$ & $5,552.6$ & $5,943.6$ & $5,683.8$ & $5,353,1$ & $4,977.2$ & $5,252.5$ \\
\hline 3. Foreign currency deposits & $8,755.3$ & $14,099.4$ & $21,802.0$ & $31,059.6$ & $33,453,0$ & $34,958.5$ & $37,046,0$ & $37,970.9$ & $39,165.5$ & $34,970.5$ & $35,994.6$ \\
\hline 4. Bonds and money market instruments & 199.0 & 124.8 & 129.5 & 137.0 & 136.5 & 127.4 & 123.9 & 154.1 & 134.5 & 138.0 & 510.7 \\
\hline 5. Foreign liabilities & $13,134.8$ & $15,148.7$ & $12,466.6$ & $13,806.5$ & $16,273.1$ & $15,921.0$ & $15,909.4$ & $16,176.8$ & $16,911.3$ & $16,383.7$ & $16,593.1$ \\
\hline 6. Central government and funds' deposits & $1,669.4$ & $2,025.6$ & $1,720.9$ & $6,874.2$ & $6,969.3$ & $7,274.5$ & $7,565.9$ & $7,298.3$ & $8,246.3$ & $8,146.0$ & $8,242.1$ \\
\hline 7. Credit from central bank & 224.0 & 182.6 & 267.7 & 33.7 & 314.2 & 444.4 & 666.8 & $1,049.2$ & 1,6339 & $1,306.8$ & $1,596.7$ \\
\hline 8. Restricted and blocked deposits & $12,081.5$ & $10,656.0$ & $8,219.2$ & $5,849.4$ & $5,083,4$ & $4,951.5$ & $4,412.9$ & $4,196.0$ & $4,456.7$ & $4,038.8$ & $3,527.2$ \\
\hline Of which: Households' blocked $\emptyset^{\prime c}$ deposits & $11,470.6$ & $9,812.5$ & $7,168.2$ & $4,571.8$ & $4,158.3$ & $3,951.7$ & $3,445.9$ & $3,419.1$ & $3,184.1$ & $3,110.5$ & $2,798.7$ \\
\hline 9. Capital accounts & $13,721.8$ & $15,116.2$ & $15,133,6$ & $16,629.9$ & $17,614.4$ & $18,834.9$ & $19,146.0$ & $19,785.6$ & $18,619.5$ & $17,859.7$ & $21,004.2$ \\
\hline 10. Other items (net) & $-1,371.7$ & $-2,012.6$ & $-2,934.0$ & $-3,577.5$ & $-4,951,2$ & $-5,235.2$ & $-5,975.2$ & $-6,797.2$ & $-5,772.4$ & $-5,554.2$ & $-6,137.7$ \\
\hline Total $(1+2+3+4+5+6+7+8+9+10)$ & $54,261.4$ & $62,239.8$ & $67,057.4$ & $84,568.5$ & $88,555.0$ & $90,884.4$ & $93,110.1$ & $93,326.4$ & $95,698.7$ & $89,925.1$ & $94,606.9$ \\
\hline
\end{tabular}

Source: Croatian National Bank.

1/ Data from O2 1999 onwards exclude sthe assets and liabilities of the banks declared bankrupt in April 1999.

2/ From Q3 1993, total provisions for identified losses are included in the capital accounts line. 
Table 52. Croatia: Deposit Rates of the Croatian National Bank, 1994-99

(In percent, annualized)

\begin{tabular}{|c|c|c|c|c|c|c|c|c|c|}
\hline \multirow{3}{*}{ Year } & \multirow{3}{*}{ Month } & \multirow{3}{*}{$\begin{array}{l}\text { On Statutory } \\
\text { Reserves with the } \\
\text { CNB }\end{array}$} & \multirow{3}{*}{$\begin{array}{l}\text { On CNB Bills on } \\
\text { Obligatory Basis }\end{array}$} & \multicolumn{6}{|c|}{ On CNB Bills } \\
\hline & & & & \multicolumn{3}{|c|}{ On a Voluntary Basis } & \multicolumn{3}{|c|}{ On a Voluntary Basis in $\mathrm{f}_{\mathrm{c}}$} \\
\hline & & & & 35 days & 91 days & 182 days & 62 days & 91 days & 182 days \\
\hline 1994 & Deceniber & 5.2 & $\ldots$ & 12.0 & 14.0 & $\ldots$ & ... & $\ldots$ & $\ldots$ \\
\hline 1995 & December & 5.5 & 16.5 & 25.5 & 27.0 & $\ldots$ & $\cdots$ & $\cdots$ & $\ldots$ \\
\hline 1996 & December & 5.5 & $\cdots$ & 8.0 & 9.5 & $\cdots$ & $\cdots$ & $\ldots$ & $\cdots$ \\
\hline \multirow[t]{12}{*}{1997} & Jamuary & 5.5 & $m$ & 7.5 & 9.0 & $\cdots$ & ... & $\ldots$ & $\ldots$ \\
\hline & February & 5.5 & ... & 7.5 & 9.0 & $\ldots$ & $\cdots$ & $\cdots$ & $\ldots$ \\
\hline & March & 5.5 & $\ldots$ & 7.5 & 9.0 & $\cdots$ & $m$ & $\cdots$ & $\ldots$ \\
\hline & April & 5.5 & $\cdots$ & 7.1 & 8.5 & $\ldots$ & $\cdots$ & $\cdots$ & $\ldots$ \\
\hline & May & 5.5 & $\ldots$ & 7.0 & 8.5 & 9.50 & $\ldots$ & $\cdots$ & $\cdots$ \\
\hline & June & 4.5 & $\ldots$ & 7.0 & 8.5 & ... & $\ldots$ & $\ldots$ & $\ldots$ \\
\hline & July & 4.5 & $\ldots$ & 7.0 & 8.5 & 9.50 & $\ldots$ & $\ldots$ & $\cdots$ \\
\hline & August & 4.5 & $\ldots$ & 7.0 & 8.5 & 9.50 & ... & $\ldots$ & $\cdots$ \\
\hline & September & 4.5 & $\cdots$ & 7.9 & 9.0 & 9.89 & $\cdots$ & $\ldots$ & $\ldots$ \\
\hline & October & 4.5 & $\cdots$ & 8.0 & 9.0 & 9.82 & ... & $\ldots$ & ... \\
\hline & November & 4.5 & $\ldots$ & 8.0 & 9.0 & 10.00 & $\cdots$ & $\cdots$ & $\ldots$ \\
\hline & December & 4.5 & $\ldots$ & 8.0 & 9.0 & 10.00 & $\ldots$ & $\ldots$ & $\ldots$ \\
\hline \multirow[t]{12}{*}{1998} & January & 4.50 & $\cdots$ & 8.0 & 9.0 & 9.75 & $\ldots$ & $\ldots$ & $\ldots$ \\
\hline & February & 4.50 & $\cdots$ & 8.5 & 9.5 & 10.00 & $\ldots$ & $\cdots$ & $\cdots$ \\
\hline & March & 4.50 & $\ldots$ & 8.6 & 9.7 & 10.06 & $\ldots$ & $\ldots$ & $\ldots$ \\
\hline & April & 4.50 & $\ldots$ & 9.2 & 10 & 10.40 & 4.1 & 3.9 & 4.6 \\
\hline & May & 4.50 & $\ldots$ & 9.5 & 11 & 11.00 & 4.1 & 3.5 & 5.6 \\
\hline & June & 4.50 & $\ldots$ & 9.5 & 11 & - & 4.1 & 3.4 & $\ldots$ \\
\hline & July & 4.50 & $\cdots$ & 9.3 & 11 & 11.00 & 4.4 & 3.8 & $\ldots$ \\
\hline & August & 4.50 & $\ldots$ & 9.5 & 11 & 11.00 & 4.4 & 3.4 & $\ldots$ \\
\hline & September & 4.50 & $\ldots$ & 9.5 & 11 & 11.00 & 4.3 & 3.4 & $\ldots$ \\
\hline & October & 5.90 & $\ldots$ & 9.5 & 11 & 11.00 & 4.5 & 3.4 & $\ldots$ \\
\hline & November & 5.90 & $\ldots$ & 9.5 & 11 & 11.00 & 4.4 & 3.5 & $\ldots$ \\
\hline & December & 5.90 & $\ldots$ & 9.5 & 11 & 11.00 & 4.6 & 3.1 & 3.1 \\
\hline \multirow[t]{9}{*}{1999} & January & 5.90 & $\begin{array}{l}\ldots \\
\ldots\end{array}$ & 9.5 & 11 & 11.00 & 3.9 & 3.0 & $\ldots$ \\
\hline & February & 5.90 & $\ldots$ & 9.5 & 11 & 11.50 & 4.0 & 2.9 & 2.9 \\
\hline & March & 5.90 & $\ldots$ & 9.7 & 11 & 11.78 & 3.8 & 3.8 & $\ldots$ \\
\hline & April & 5.90 & $\ldots$ & 10.1 & 11 & 12.00 & 4.0 & 2.6 & $\ldots$ \\
\hline & May & 5.90 & $\ldots$ & 10.1 & 11 & 12.00 & 3.4 & 2.6 & $\ldots$ \\
\hline & June & 5.90 & $\ldots$ & 10.1 & 11 & 12.13 & 3.9 & 2.4 & 5.2 \\
\hline & July & 5.90 & $\ldots$ & 10.1 & 11 & 12.15 & 4.1 & 2.5 & $\ldots$ \\
\hline & August & 5.90 & $\ldots$ & 10.1 & 11 & 12.20 & 3.8 & 2,5 & $\ldots$ \\
\hline & September & 5.90 & $\cdots$ & 10.3 & 11 & 12.28 & 4.0 & 2.7 & 5.8 \\
\hline
\end{tabular}

Source: Croatian National Bank. 
Table 53. Croatia: Croatian National Bank Credit Facilities

\begin{tabular}{|c|c|c|c|}
\hline Loan type & Purpose and Conditions & Maturity & Interest rate ${ }^{t}$ \\
\hline ; & $\begin{array}{l}\text { These secured credits are granted } \\
\text { in amounts up to } 50 \text { percent of a } \\
\text { bank's holdings of CNB bills in } \\
\text { kuna, treasury bills, and Ministry } \\
\text { of Finance bills of exchange, and } \\
40 \text { percent of a bank's holdings of } \\
\text { CNB bills in foreign currency. }\end{array}$ & $\begin{array}{l}\text { These loans may be used } \\
\text { for a maximum of } 15 \\
\text { working days days within } \\
\text { a month. }\end{array}$ & 13 percent \\
\hline Intervention credit & $\begin{array}{l}\text { These credits are available to } \\
\text { banks if they have a negative } \\
\text { liquidity balance at the end of the } \\
\text { business day, having exhausted } \\
\text { all avenues to obtain additional } \\
\text { funds from the money market or } \\
\text { through Lombard credits. }\end{array}$ & $\begin{array}{l}\text { These credits must be } \\
\text { repaid the next working } \\
\text { day. }\end{array}$ & 19 percent \\
\hline $\begin{array}{l}\text { Short-term liquidity } \\
\text { credit }\end{array}$ & $\begin{array}{l}\text { These credits are available within } \\
\text { the framework of the measures } \\
\text { taken by the CNB, pursuant to the } \\
1998 \text { Law on Banks, for } \\
\text { improving the situation of a bank } \\
\text { experiencing liquidity problems } \\
\text { but meeting solvency criteria. } \\
\text { Amounts and terms are } \\
\text { determined by the CNB } \\
\text { Governor. Strictly specified high } \\
\text { quality collateral is required. }\end{array}$ & $\begin{array}{l}\text { To be determined by the } \\
\text { CNB. }\end{array}$ & 14 percent \\
\hline $\begin{array}{l}\text { Illiquidity bridging } \\
\text { loans }\end{array}$ & $\begin{array}{l}\text { This loan can be granted to banks } \\
\text { in the period during which the } \\
\text { CNB is assessing the economic } \\
\text { feasibility of initiating the } \\
\text { rehabilitation process. The } \\
\text { amount is determined by the CNB } \\
\text { Governor. High quality } \\
\text { guarantees are required and } \\
\text { determined by the loan contract. }\end{array}$ & $\begin{array}{l}\text { Loans must be repaid } \\
\text { within } 90 \text { days or, if the } \\
\text { bank is subject to } \\
\text { rehabilitation, } \\
\text { immediately after the } \\
\text { receipts of the funds } \\
\text { granted for its. } \\
\text { rehabilitation. }\end{array}$ & 14 percent \\
\hline $\begin{array}{l}\text { Repurchase } \\
\text { agreements }\end{array}$ & $\begin{array}{l}\text { These agreements are organized } \\
\text { at the discretion of the CNB for } \\
\text { bridging short-tern illiquidity or } \\
\text { mopping up excess liquidity. } \\
\text { CNB and Treasury bills are } \\
\text { eligible securities. }\end{array}$ & $\begin{array}{l}\text { To be determined by the } \\
\text { CNB }\end{array}$ & $\begin{array}{l}\text { Auction } \\
\text { determined }\end{array}$ \\
\hline $\begin{array}{l}\text { Foreign exchange } \\
\text { swap }\end{array}$ & $\begin{array}{l}\text { Swaps are organized at the } \\
\text { discretion of the CNB for } \\
\text { bridging short-term illiquidity } \\
\text { problems. Only fully licensed } \\
\text { banks are entitled to participate. }\end{array}$ & $\begin{array}{l}\text { To be determined by the } \\
\text { CNB. }\end{array}$ & - \\
\hline
\end{tabular}

\footnotetext{
${ }^{1}$ As of end-November, 1999.
} 
Table 54. Croatia: Credit rates of the Croatian National Bank, 1994-99 (in percent, annualized)

\begin{tabular}{|c|c|c|c|c|c|c|c|c|}
\hline & Month & $\begin{array}{l}\text { CNB } \\
\text { Discount } \\
\text { Rate }\end{array}$ & $\begin{array}{l}\text { On } \\
\text { lombard } \\
\text { credits }\end{array}$ & $\begin{array}{c}\text { On } \\
\text { intervention } \\
\text { credits }\end{array}$ & $\begin{array}{l}\text { Intra-day } \\
\text { refinmoe } \\
\text { facility }\end{array}$ & $\begin{array}{l}\text { On short-tem } \\
\text { liquidity } \\
\text { credits }\end{array}$ & $\begin{array}{l}\text { On inaccurately } \\
\text { calculated } \\
\text { statutory reserves }\end{array}$ & On arrears \\
\hline 1994 & Decermber & 8.50 & 18.00 & 19.00 & 17.00 & 14.00 & 19.00 & 22.00 \\
\hline 1995 & December & 8.50 & 25.49 & 19.00 & 17.00 & ... & 19.00 & 22,00 \\
\hline 1996 & Decerrber & 6.50 & 11,00 & 19.00 & 17.00 & $\ldots$ & 19.00 & 18.00 \\
\hline \multirow[t]{6}{*}{1997} & January & 6.50 & 11,00 & 19.00 & 17.00 & $\ldots$ & 19.00 & 18.00 \\
\hline & February & 6.50 & 11.00 & 39.00 & 17.00 & $\ldots$ & 19,00 & 18.00 \\
\hline & March & 5.90 & 9.50 & 19.00 & 17.00 & $\ldots$ & 19.00 & 18.00 \\
\hline & April & 5.90 & 9.50 & 19.00 & 17.00 & $\therefore$ & 19.00 & 18.00 \\
\hline & May & 5.90 & 9.50 & 19.00 & 37.00 & $\ldots$ & 19.00 & 18.00 \\
\hline & Juse & 5.90 & 9.50 & 19.00 & 17.00 & $\ldots$ & 19.00 & 38.00 \\
\hline \multirow[t]{6}{*}{. } & Iuly & $\$ .90$ & 9.50 & 19.00 & 17.00 & $\ldots$ & 19.00 & 18.00 \\
\hline & Augast & 5.90 & 9.50 & 19.00 & 17.00 & $\ldots$ & 19.00 & 18,00 \\
\hline & Septernher & 5.90 & 9.50 & 19.00 & 17.00 & $\ldots$ & 19.00 & 18,00 \\
\hline & October & 5.90 & 9.50 & 19.00 & 17.00 & $\ldots$ & 19.00 & 18.00 \\
\hline & Novenber & 5.90 & 9.50 & 19.00 & 17.00 & $\ldots$ & 19.00 & 18.00 \\
\hline & December & 5.90 & 9.50 & 19.00 & 17.00 & $\ldots$ & 19,00 & 18.00 \\
\hline \multirow{12}{*}{1998.} & January & 5.90 & 9.50 & 19.00 & 17.00 & $\ldots$ & 19.00 & 18.00 \\
\hline & Februaty & 5.90 & 9.50 & 19.00 & 17.00 & $\ldots$ & 19.00 & 18.00 \\
\hline & March & 5.90 & 9.50 & 19.00 & 17.00 & 14.00 & 19.00 & 18.00 \\
\hline & Apri] & 5.90 & 11.00 & 19.00 & 17.00 & 14.00 & 19.00 & 18.00 \\
\hline & May & 5.90 & 11.00 & 19.00 & 17.00 & 14.00 & 19.00 & 18.00 \\
\hline & June & 5.90 & 11.00 & 19.00 & 17.00 & 14.00 & 19.00 & 18,00 \\
\hline & July & 5.90 & 11.00 & 19.00 & 17.00 & 14.00 & 19,00 & 18.00 \\
\hline & August & 5.90 & 11.00 & 19.00 & 17.00 & 14.00 & 19.00 & 18.00 \\
\hline & September & 5.90 & 11.00 & 19.00 & 7.00 & 14.00 & 19.00 & 18.00 \\
\hline & Oetober & 5.90 & 11.00 & 19.00 & 7.00 & .14 .00 & 19.00 & 18.00 \\
\hline & Novenber & 5.90 & 11,00 & 19.00 & 7.00 & 14.00 & 19.00 & 18.00 \\
\hline & December & 5.90 & 1200 & 19.00 & 7.00 & 14.00 & 19.00 & 18.00 \\
\hline \multirow{9}{*}{1999.} & Janusery & 5.90 & 12.00 & 19.00 & 7.00 & 14.00 & 19.00 & 18.00 \\
\hline & February & 5.90 & 12.00 & 19.00 & 7.00 & 14.00 & 19.00 & 18.00 \\
\hline & March & 7.90 & 13.00 & 19.00 & 7.00 & 14.00 & 19.00 & 18.00 \\
\hline & April & 7.90 & 13.00 & 19.00 & 7.00 & 14.00 & 19.00 & 18.00 \\
\hline & May & 7.90 & 13.00 & 19.00 & $\ldots$ & 14.00 & 19.00 & 18.00 \\
\hline & June & 7.90 & 13.00 & 19.00 & $\ldots$ & 14.60 & 19.00 & 18.00 \\
\hline & July & 7.90 & 13.00 & 19.00 & $\ldots$ & 14.00 & 19.00 & 18.00 \\
\hline & Augurt & 7.90 & 13.00 & 19.00 & $\ldots$ & 14.00 & 19.00 & 18.00 \\
\hline & Septeriber & 7.90 & 13.00 & 19.00 & $\ldots$ & 14.00 & 19.00 & 18.00 \\
\hline
\end{tabular}

Source: Croatian National Bank. 
Table 55. Croatia: Deposit Money Banks' Deposit Rates, 1994-99

(Monthly weighted average; in percent, annualized)

\begin{tabular}{|c|c|c|c|}
\hline & $\begin{array}{l}\text { Interest Rates on } \\
\text { Deposits in Kuna }\end{array}$ & $\begin{array}{l}\text { Interest Rates on } \\
\text { Deposits in Kuna } \\
\text { Indexed to } \mathrm{f} / \mathrm{x}\end{array}$ & $\begin{array}{l}\text { Interest Rates on } \\
\text { Deposits in } \mathbf{f} x\end{array}$ \\
\hline $1994 \mathrm{Dec}$ & 5.0 & 7.0 & $\ldots$ \\
\hline $1995 \mathrm{Dec}$ & 6.1 & 12.7 & 4.6 \\
\hline $1996 \mathrm{Dec}$ & 4.2 & 9.5 & 5.1 \\
\hline 1997 Jan & 4.2 & 9.8 & 4.5 \\
\hline $\mathrm{Feb}$ & 4.3 & 9.5 & 4.2 \\
\hline Mar & 4.4 & 8.6 & 4.3 \\
\hline Apr & 4.4 & 9.2 & 4.4 \\
\hline May & 4.4 & 9.5 & 4.5 \\
\hline Jun & 4.3 & 10.3 & 4.4 \\
\hline Jul & 4.2 & 8.0 & 4.3 \\
\hline Aug & 4.2 & 9.5 & 4.1 \\
\hline Sept & 4.3 & 8.8 & 4.3 \\
\hline Oct & 4.3 & 6.8 & 4.2 \\
\hline Nov & 4.1 & 8.8 & 4.5 \\
\hline Dec & 4.4 & 7.6 & 4.8 \\
\hline $1998 \mathrm{Jan}$ & 4.7 & 7.3 & 5.1 \\
\hline Feb & 4.5 & 7.4 & 5.6 \\
\hline Mar & 4.5 & 7.7 & 5.5 \\
\hline Apr & 4.9 & 7.7 & 5.4 \\
\hline May & 4.8 & 9.4 & 5.6 \\
\hline Jun & 4.7 & 9.6 & 5.6 \\
\hline Jul & 4.7 & 9.2 & 5.3 \\
\hline Aug & 4.7 & 9.9 & 5.3 \\
\hline Sept & 4.8 & 7.4 & 4.3 \\
\hline Oct & 4.6 & 7.5 & 4.4 \\
\hline Nov & 4.6 & 7.1 & 4.4 \\
\hline Dec & 4.1 & 7.5 & 4.0 \\
\hline 1999 Jan & 4.5 & 6.5 & 4.3 \\
\hline Feb & 4.6 & 7.0 & 4.2 \\
\hline Mar & 4.5 & 7.5 & 4.1 \\
\hline Apr & 4.3 & 6.5 & 4.2 \\
\hline May & 4.3 & 7.4 & 4.2 \\
\hline Jun & 4.2 & 6.2 & 4.1 \\
\hline Jul & 4.1 & 5.9 & 3.9 \\
\hline Aug & 4.1 & 6.2 & 4.3 \\
\hline Sept & 4.2 & 6.6 & 4.1 \\
\hline
\end{tabular}

Source: Croatian National Bank. 
Table 56. Croatia: Deposit Money Banks' Credit Rates, 1994-99

(Monthly weighted average; in percent, annualized)

\begin{tabular}{|c|c|c|c|}
\hline & $\begin{array}{l}\text { Interest Rates on } \\
\text { Credits in Kuna }\end{array}$ & $\begin{array}{l}\text { Interest Rates on Credits } \\
\text { in Kuna Indexed to } f / x\end{array}$ & $\begin{array}{l}\text { Interest Rates on } \\
\text { Credits in } \mathrm{f} / \mathrm{x}\end{array}$ \\
\hline $1994 \mathrm{Dec}$ & 15.4 & 12.0 & $\ldots$ \\
\hline $1995 \mathrm{Dec}$ & 22.3 & 19.6 & 15.7 \\
\hline 1996 Dec & 18.5 & 19.0 & 19.3 \\
\hline $1997 \mathrm{Jan}$ & 17.6 & 20.1 & 23.5 \\
\hline Feb & 17.2 & 17.6 & 20.4 \\
\hline Mar & 16.9 & 18.1 & 19.1 \\
\hline Apr & 16.9 & 17.0 & 17.7 \\
\hline May & 15.8 & 16.6 & 17.9 \\
\hline Jun & 15.3 & 15.4 & 16.7 \\
\hline Jul & 15.0 & 15.2 & 15.5 \\
\hline Aug & 14.2 & 15.7 & 13.6 \\
\hline Sept & 14.3 & 15.8 & 15.3 \\
\hline Oct & 14.6 & 15.9 & 18.7 \\
\hline Nov & 13.7 & 15.5 & 17.5 \\
\hline Dec & 14.1 & 14.4 & 13.6 \\
\hline 1998 Jan & 14.7 & 15.4 & 16.1 \\
\hline Feb & 14.5 & 15.2 & 15.5 \\
\hline Mar & 14.8 & 15.2 & 14.6 \\
\hline Apr & 15.3 & 15.2 & 15.8 \\
\hline May & 16.7 & 15.1 & 15.1 \\
\hline Jun & 17.0 & 14.9 & 14.9 \\
\hline Jul & 16.0 & 15.0 & 5.4 \\
\hline Aug & 15.7 & 15.2 & 5.8 \\
\hline Sept & 15.6 & 13.4 & 7.4 \\
\hline Oct & 16.3 & 14.3 & 7.4 \\
\hline Nov & 16.4 & 13.6 & 7.1 \\
\hline Dec & 16.1 & 13.0 & 7.0 \\
\hline $1999 \mathrm{Jan}$ & 16.1 & 13.9 & 6.9 \\
\hline Feb & 16.9 & 13.6 & 6.3 \\
\hline Mar & 16.3 & 13.2 & 5.7 \\
\hline Apr & 16.0 & 13.4 & 6.3 \\
\hline May & 16.6 & 13.4 & 5.5 \\
\hline Jun & 14.2 & 13.3 & 5.2 \\
\hline Jul & 14.6 & 12.7 & 6.6 \\
\hline Aug & 14.6 & 13.1 & 5.7 \\
\hline Sept & 14.0 & 12.9 & 6.0 \\
\hline
\end{tabular}

Source: Croatian National Bank. 
Table 57. Croatia: Balance of Payments 1993-99 1/

(Millions of U.S. dollars, urless otherwise indicated)

\begin{tabular}{|c|c|c|c|c|c|c|c|c|}
\hline & \multirow[t]{2}{*}{1993} & \multirow[t]{2}{*}{1994} & \multirow[t]{2}{*}{1995} & \multirow[t]{2}{*}{1996} & \multirow[t]{2}{*}{1997} & \multirow[t]{2}{*}{1998} & \multicolumn{2}{|c|}{1999} \\
\hline & & & & & & & Jan,-Mar. A & $\begin{array}{l}\text { Apr.Jun. } \\
\text { (Preilim.) }\end{array}$ \\
\hline Current account & 606 & 826 & -1451 & -1148 & $-2,343$ & $-1,543$ & .541 & .528 \\
\hline Merchandise trade belance & .742 & $-1,172$ & $-3,268$ & $-3,690$ & $-5,224$ & $-4,161$ & -662 & .955 \\
\hline Exports fo.b. & 3,904 & 4,260 & 4,633 & 4,546 & 4,210 & 4,613 & 984 & 1.041 \\
\hline Importas J.o.b. & $-4,645$ & $-5,432$ & $-7,901$ & $-8,236$ & $-9,435$ & $-8,773$ & $-1,646$ & $-1,996$ \\
\hline Services and income & 1,019 & 1,469 & 1,013 & 1,510 & 2,010 & 1,910 & -17 & 303 \\
\hline Transportation & 314 & 321 & 314 & 310 & 283 & 228 & 16 & 23 \\
\hline Travel & 935 & 1,405 & 924 & 1,504 & 2,000 & 2,133 & 81 & 389 \\
\hline Other services & -112 & -93 & -197 & -234 & -251 & -286 & .50 & .39 \\
\hline Compensation of employees & 17 & 35 & 39 & 39 & 56 & 70 & 16 & 14 \\
\hline Interest income & -137 & -200 & -67 & -109 & .76 & -235 & .79 & -84 \\
\hline Current transfers & 329 & 529 & 804 & 1,032 & 872 & 708 & 139 & 124 \\
\hline Capital and Financial account & -163 & 38 & 1,132 & 2,472 & 3,120 & 1,647 & $\$ 44$ & 622 \\
\hline Capital account & 0 & 0 & 0 & 16 & 21 & 19 & 5 & 0 \\
\hline Finsncial account & -163 & 38 & 1,132 & 2,456 & 3,099 & 1,628 & 438 & 622 \\
\hline Direct investment & 78 & 106 & 96 & 509 & 302 & 775 & 75 & 122 \\
\hline Pottolia investratent & 0 & 9 & 5 & 27 & 665 & 25 & 319 & -12 \\
\hline Medium- and lonf-term loans & -190 & -145 & -142 & 454 & 1,205 & 1,058 & -19 & .34 \\
\hline Disbursements & 154 & 184 & 315 & 844 & 1,792 & 1,775 & 133 & 91 \\
\hline Amortization scheduled & -343 & -329 & -457 & -391 & -587 & -717 & -152 & .124 \\
\hline Currency and deposits $2 /$ & -149 & 58 & 704 & 840 & 443 & 218 & 233 & -394 \\
\hline Shart term capital flows (net) 3/ & 97 & 10 & 470 & 199 & 248 & 36 & $3 t$ & 289 \\
\hline Traoce Credits 4/ & 0 & 0 & 0 & 426 & 236 & -484 & -202 & 650 \\
\hline Net errors and omissions & -226 & -540 & 406 & -422 & -590 & 181 & -258 & 68 \\
\hline Overall balance & 217 & 324 & 87 & 903 & 188 & 285 & -355 & 162 \\
\hline Finzincing & -217 & -324 & .87 & .903 & -188 & -285 & 355 & -152 \\
\hline Gross reserves ( $-m$ increase) & -451 & -789 & -490 & -419 & -225 & -277 & 358 & -152 \\
\hline MMF (net purchases) & .24 & 106 & 98 & -4 & 37 & -9 & -2 & -10 \\
\hline Exceptional Grancing & 258 & 360 & 306 & -479 & 0 & $a$ & 0 & 0 \\
\hline \multicolumn{9}{|l|}{ Merporendum Items } \\
\hline Current account (in percent of GDP) & 5.6 & 5.7 & -7.3 & -5.8 & -11.6 & -7.1 & -11.0 & -10.7 \\
\hline Current account (in percent of adjusted GDP) $5 /$ & 4.4 & 4.5 & -6.2 & -4.6 & -9.3 & -5.7 & -8.8 & -8.6 \\
\hline Gross reserves (millions of US dollars) & 616 & 1,405 & 1.895 & 2,314 & 2,539 & 2,816 & 2,458 & 2,610 \\
\hline Reserves in months of imports of goods and NFS & 1.3 & 2.5 & 2.4 & 2.8 & 2.7 & 3.2 & 3.0 & 3.2 \\
\hline Net international rescrves (miltians of US dolkers) & 574 & 1,286 & 1,674 & 2,105 & 2,306 & 2,581 & 2,234 & 2,399 \\
\hline in months of imports of goods and NFS & & 2.3 & 2.2 & 2.5 & 2.4 & 2.9 & 12.3 & 11.8 \\
\hline Gross ussable reserves (mizlions of US dollars) 6 & 616 & 1,405 & 1,895 & 2,314 & 2,539 & 2,320 & 1.763 & 1,872 \\
\hline Gross useble reserves in months of imports of goods and NFS 6 f & 1.3 & 2.5 & 2.4 & 2.8 & 27 & 2.6 & 2.2 & 2.3 \\
\hline Net usabie intemational reserves (millions of US dollars) & 574 & 1,286 & 1,674 & 2,105 & 2,306 & 2,085 & 1,539 & 1,661 \\
\hline in months of imports of goods ayd NFS & & 2.3 & 2.2 & 2.5 & 2.4 & 2.3 & 8.5 & 8.1 \\
\hline Outstanding debt (USSm) 7 & 2,942 & 3,282 & 3,921 & $4,6 ! 1$ & 6,420 & 8,062 & 8,163 & 8,195 \\
\hline of which : short-term debt $3 / 8$ / & so & 37 & 208 & 355 & 441 & 366 & 357 & 582 \\
\hline Debs to GDP ratio $7 /$ & 27.0 & 22.5 & 20.8 & 23.2 & 31.9 & 37.1 & 40.6 & 40.8 \\
\hline Short-term debt in percent of gross usable reserves $3 / 8 / 9 /$ & 61.5 & 35.2 & 31.6 & 40.7 & 45.6 & 51.4 & & \\
\hline Short-tern debt and current account deficit ret of FDI in percent of & & & & & & & & \\
\hline gross usable reserves $3 / 8 / 9 /$ & -89.8 & 131.7 & 65.3 & 128.9 & 75.9 & 55.8 & & \\
\hline Debe Service & -591 & -642 & -698 & -713 & -848 & -1110 & -262 & -180 \\
\hline Debt service to exports ratio & 9.5 & 9.0 & 9.9 & 9.1 & 10.3 & 12.9 & 16.7 & 9.6 \\
\hline GDP (millions of US dollars) & 10,904 & 14,583 & 18,811 & 19,871 & 20,109 & 21.752 & 4,902 & 4,918 \\
\hline GDP(Millions of Kuns) & 39,000 & 87.441 & 98,382 & 107,981 & 123,813 & 138,392 & 32,623 & 35,308 \\
\hline \multicolumn{9}{|l|}{ Exchange rates } \\
\hline Kung per US roller (pB) & 3.58 & 6.00 & 5.23 & 5.43 & 6.16 & 6.4 & 6.7 & 7.2 \\
\hline
\end{tabular}

Sources: Croatian National Bank, World Economic Outlook, and staff estimates

1/ Based upon CNB bilance of payments revisions of summer 1999.

2 A significant proportion of the currency and deposit flows in 1998 and 1999 are the repatriation of foreign currency redeposit requirements held at the CNB.

3/ Data for short term commercial bark eredits derived from the CNB foreign exchange department.

4/ Coverage only includes import trade credits with maturities less than three months.

5! Includes an upward adjustment of 25 percent to GDP for the informat sector. While the exact size of the needed adjustment is nat known, some such upward adjustment is ciearly warranted and ostinates by the Ministry of Finance and the institute of Public Finance in Zagreb suggest that an adjustrent on the order of 25 percent would be reasonable.

6/ Gross teserves adjusted downward by foreign curency redeposit requirements held at the CNB, and by the amount of outstanding foreign currency

CNB bills.

7/ Does not include debt that was excluded from the London Club agreement.

8/ Coverage is limited to short term debt contracts registered with the CNB.

9/ Shot-term debt is presented on a remaining maturity basis. 
Table 58. Croatia: Merchandise Exports and Imports, 1997-99 1/

(In millions of U.S. dollars)

\begin{tabular}{|c|c|c|c|c|c|c|}
\hline & \multicolumn{2}{|c|}{ Overall } & \multicolumn{2}{|c|}{$\begin{array}{l}\text { World Except Former } \\
\text { Yugoslav Republics }\end{array}$} & \multicolumn{2}{|c|}{$\begin{array}{c}\text { Former Yugoslav } \\
\text { Republics }\end{array}$} \\
\hline & Exports & Imports & Exports & Imports & Exports & Imports \\
\hline 1997 & 4,171 & 9,104 & 2,919 & 8,163 & 1,252 & 941 \\
\hline January & 484 & 652 & 331 & 586 & 153 & 66 \\
\hline February & 356 & 719 & 254 & 653 & 102 & 66 \\
\hline March & 339 & 669 & 248 & 595 & 91 & 74 \\
\hline April & 321 & 635 & 232 & 565 & 89 & 70 \\
\hline May & 330 & 758 & 232 & 675 & 98 & 83 \\
\hline June & 344 & 782 & 251 & 699 & 93 & 83 \\
\hline July & 310 & 743 & 222 & 668 & 88 & 75 \\
\hline August & 296 & 630 & 184 & 554 & 112 & 76 \\
\hline September & 360 & 785 & 249 & 707 & 111 & 78 \\
\hline October & 341 & 776 & 230 & 685 & 111 & 91 \\
\hline November & 366 & 856 & 252 & 761 & 114 & 95 \\
\hline December & 323 & 1,100 & 235 & 1,015 & 88 & 85 \\
\hline 1998 & 4,541 & 8,383 & 3,374 & 7,430 & 1,167 & 953 \\
\hline January & 316 & 606 & 230 & 551 & 86 & 55 \\
\hline February & 334 & 581 & 249 & 514 & 85 & 67 \\
\hline March & 431 & 743 & 327 & 656 & 104 & 87 \\
\hline April & 323 & 613 & 239 & 543 & 84 & 70 \\
\hline May & 420 & 810 & 312 & 716 & 108 & 94 \\
\hline June & 353 & 765 & 262 & 684 & 91 & 81 \\
\hline July & 349 & 781 & 252 & 690 & 97 & 91 \\
\hline August & 369 & 595 & 278 & 520 & 91 & 75 \\
\hline September & 453 & 750 & 342 & 651 & 111 & 99 \\
\hline October & 464 & 770 & 353 & 677 & 111 & 93 \\
\hline November & 378 & 765 & 266 & 686 & 108 & 79 \\
\hline December & 350 & 603 & 259 & 542 & 91 & 61 \\
\hline \multicolumn{7}{|l|}{1999} \\
\hline January & 349 & 575 & 267 & 511 & 82 & 64 \\
\hline February & 278 & 543 & 202 & 489 & 76 & 54 \\
\hline March & 334 & 548 & 252 & 487 & 82 & 61 \\
\hline April & 321 & 633 & 227 & 567 & 94 & 66 \\
\hline May & 384 & 681 & 276 & 607 & 108 & 74 \\
\hline June & 313 & 718 & 234 & 651 & 79 & 67 \\
\hline July & 417 & 750 & 330 & 674 & 87 & 76 \\
\hline August & 363 & 539 & 282 & 478 & 81 & 61 \\
\hline September & 399 & 653 & 295 & 571 & 104 & 82 \\
\hline
\end{tabular}

Source: Central Bureau of Statistics.

1/ Data have not been revised in line with the 1998 balance of payments compilation methodology. Includes trade with countries of the former SFRY. 
Table 59. Croatia: Composition of Exports (SITC), 1993-98 1/

(In millions of U.S. dollars)

\begin{tabular}{|c|c|c|c|c|c|c|}
\hline & \multicolumn{6}{|c|}{ Total } \\
\hline & 1993 & 1994 & 1995 & 1996 & 1997 & 1998 \\
\hline Total & 3,904 & 4,232 & 4,633 & 4,512 & 4,171 & 4,541 \\
\hline Food products & 367 & 369 & 395 & 411 & 385 & 385 \\
\hline Live animals & 22 & 5 & 6 & 7 & 5 & 3 \\
\hline Meat and meat products & 49 & 60 & 50 & 47 & 54 & 50 \\
\hline Fish and fish products & 49 & 50 & 45 & 49 & 60 & 43 \\
\hline Grain and grain products & 74 & 64 & 75 & 64 & 36 & 54 \\
\hline Fruit and vegetables. & 40 & 40 & 42 & 40 & 28 & 24 \\
\hline Coffee, tea, cocos and spices & 25 & 1 & 34 & 31 & 31 & 30 \\
\hline Livestock feed & 10 & 21 & 15 & 15 & 21 & 23 \\
\hline Other food products & 98 & 128 & 128 & 158 & 149 & 158 \\
\hline Beverages and tobacco & 101 & 67 & 90 & 92 & 121 & 111 \\
\hline Raw materials, excluding fueis & 237 & 214 & 251 & 247 & 261 & 231 \\
\hline Oil seeds, for planting and consumption & 1 & 2 & 4 & 2 & 4 & 5 \\
\hline Raw rubber & 0 & 0 & 0 & 0 & 0 & 0 \\
\hline Wood, framing lumber and cork & 168 & 144 & 161 & 166 & 168 & 157 \\
\hline Textile fibers and waste material & 6 & 6 & 7 & 3 & 2 & 3 \\
\hline Raw fertilizers and minerals & 12 & 13 & 13 & 13 & 19 & 14 \\
\hline Metal ores and scrap & 10 & 20 & 22 & 20 & 31 & 23 \\
\hline Other raw materials & 40 & 29 & 44 & 43 & 37 & 29 \\
\hline Mineral fuels and lubricants & 377 & 386 & 391 & 416 & 426 & 264 \\
\hline Petroleum and petroleum products & 322 & 344 & 366 & 371 & 385 & 232 \\
\hline Gas, natural and industrial & 18 & 16 & 22 & 28 & 40 & 30 \\
\hline Other fuels and lubricants & 37 & 26 & 3 & 17 & 1 & 1 \\
\hline Aninal and vegetable oil and fats & 4 & 7 & 9 & 10 & 14 & 16 \\
\hline Chemical products & 564 & 543 & 814 & 643 & 570 & 545 \\
\hline Organic chemicals & 61 & 43 & 53 & 44 & 36 & 31 \\
\hline Paints, material for tanning and dyeing & 16 & 14 & 18 & 23 & 24 & 20 \\
\hline Medical and pharmaceutical products & 100 & 133 & 137 & 139 & 157 & 149 \\
\hline Synthetic fuels & 77 & 86 & 112 & 118 & 87 & 76 \\
\hline Plastic, cellulose resins & 145 & 177 & 361 & 209 & 171 & 176 \\
\hline Other chemical products & 166 & 90 & 133 & 110 & 96 & 93 \\
\hline Products classified according to constituent material & 526 & 654 & 670 & 594 & 589 & $\$ 84$ \\
\hline Rubber products & 11 & 13 & 9 & 9 & 8 & 9 \\
\hline Paper, cardboard and products thereof & 80 & 98 & 107 & 62 & 72 & 63 \\
\hline Textile yarns, textiles and the like & 95 & 129 & 124 & 110 & 91 & 89 \\
\hline Non-metal mineral products & 102 & 126 & 126 & 135 & 133 & 131 \\
\hline Raw iron and stee] & 66 & 69 & 59 & 48 & 64 & 68 \\
\hline Non-ferrous metals & 41 & 50 & 73 & 65 & 62 & 62 \\
\hline Other metal products & 131 & 168 & 172 & 165 & 160 & 162 \\
\hline Machines and transport equipment & 552 & 732 & 778 & 964 & 752 & 1380 \\
\hline Special machines for specific industries & 32 & 47 & 45 & $\$ 1$ & 42 & 52 \\
\hline Metal-working tools & 17 & 15 & 28 & 24 & 31 & 38 \\
\hline General-purpose industrial machines & 39 & 42 & 52 & 54 & 59 & 55 \\
\hline Electrical machines, devices and tools & 143 & 172 & 211 & 219 & 227 & 234 \\
\hline Other machines and transport equipment & 321 & 456 & 442 & 616 & 393 & 1001 \\
\hline Miscellaneous ready-made products & 1,169 & 1,257 & 1,233 & 1,133 & 1,049 & 1,023 \\
\hline Household furmishings & 148 & 138 & 151 & 120 & 125 & 107 \\
\hline Clothing & 644 & 629 & 673 & 633 & 555 & 556 \\
\hline Footwear & 225 & 279 & 234 & 235 & 226 & 199 \\
\hline Scientific and monitoring instruments & 13 & 17 & 28 & 22 & 23 & 26 \\
\hline Other ready-made products & 139 & 194 & 147 & 123 & 120 & 135 \\
\hline Miscellaneous transactions and goods & 7 & 3 & 2 & 2 & 2 & 3 \\
\hline
\end{tabular}

Source: Central Bureau of Statistics.

1/ Data have not been revised in line with the 1998 balance of payments compilation methodology. Includes trade with countries of the former SFRY. 
Table 60. Croatia: Composition of Imports (SITC), 1993-98 1/

(In millions of U.S. dollars)

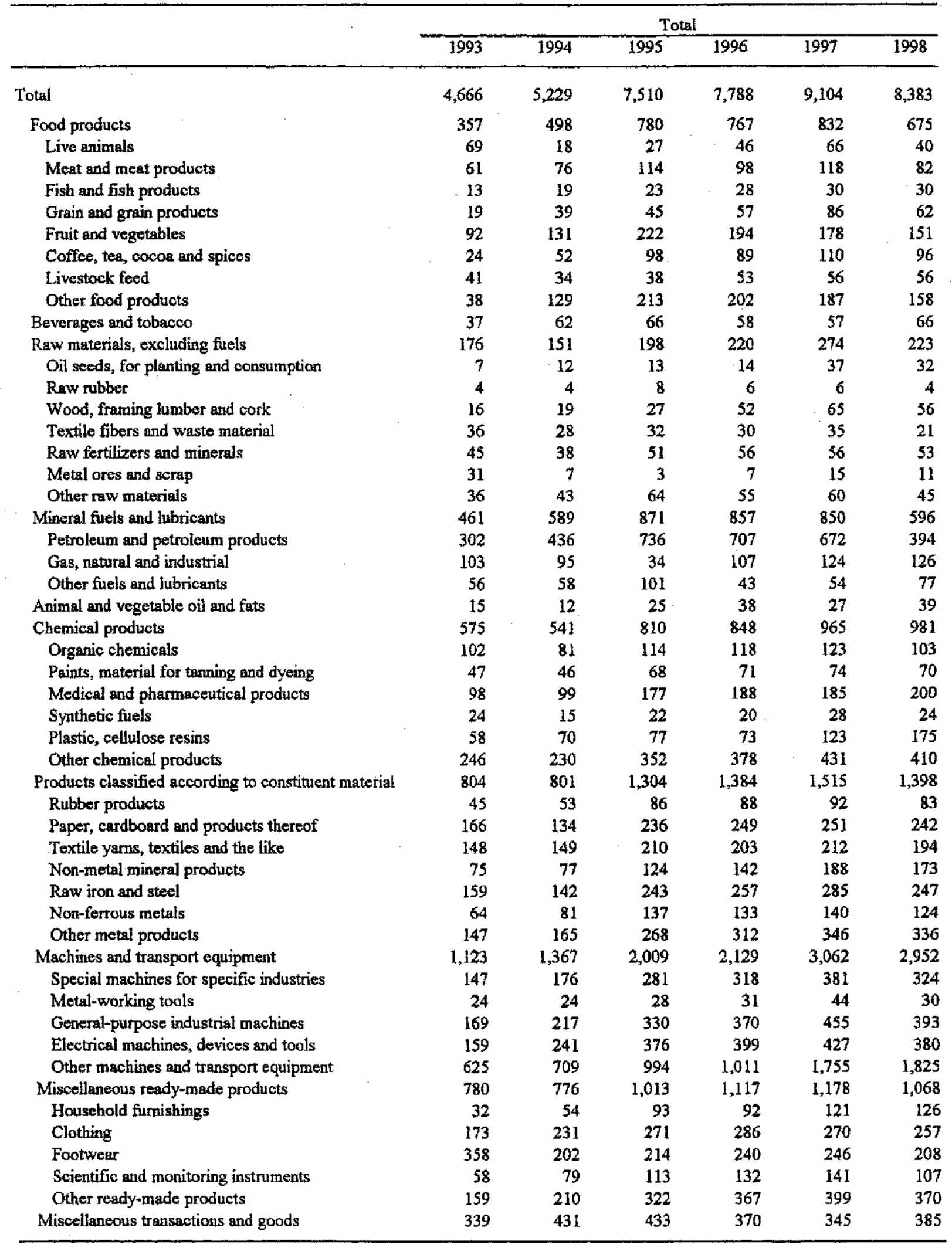

Source: Central Bureau of Statistics.

1/ Data have not been revised in line with the 1998 balance of payments compilation methodology. Includes trade with countries of the former SFRY. 
Table 61. Croatia: Exports by Destination, 1993-98 1/

(In millions of U.S. dollars)

\begin{tabular}{|c|c|c|c|c|c|c|}
\hline & 1993 & 1994 & 1995 & 1996 & 1997 & 1998 \\
\hline Total & 3,904 & 4,260 & 4,633 & 4,512 & 4,171 & 4,541 \\
\hline Developed countries & 2,419 & 2,729 & 2,862 & 2,478 & 2,272 & 2,381 \\
\hline EU countries & 2,245 & 2,531 & 2,672 & 2,303 & 2,074 & 2,161 \\
\hline Austria & 130 & 149 & 200 & 198 & 223 & 247 \\
\hline Belgium & 29 & 38 & 43 & 41 & 38 & 40 \\
\hline Denmark & 7 & 10 & 7 & 4 & 6 & 5 \\
\hline France & 133 & 111 & 110 & 84 & 80 & 102 \\
\hline Italy & 828 & 910 & 1,098 & 949 & 787 & 802 \\
\hline Netherlands & 92 & 94 & 80 & 69 & 62 & 53 \\
\hline Germany & 895 & 941 & 997 & 839 & 746 & 767 \\
\hline Sweden & 25 & 164 & 14 & 13 & 16 & 19 \\
\hline Great Britain & 73 & 68 & 57 & 70 & 67 & 71 \\
\hline Other & 33 & 46 & 65 & 35 & 49 & 54 \\
\hline EFTA countries & 45 & 65 & 59 & 41 & 49 & 80 \\
\hline Norway & 3 & 4 & 5 & 3 & 4 & 36 \\
\hline Switzerfand & 40 & 60 & 52 & 37 & 41 & 41 \\
\hline Other & 2 & 1 & 2 & 1 & 4 & 3 \\
\hline Other developed countries & 129 & 133 & 131 & 135 & 149 & 140 \\
\hline Australia & 6 & 5 & 6 & 4 & 5 & 7 \\
\hline Japan & 1 & 1 & 1 & 2 & 6 & 7 \\
\hline Canada & 5 & 5 & 7 & 8 & 9 & 8 \\
\hline U.S.A. & 82 & 88 & 83 & 89 & 97 & 89 \\
\hline Turkey & 20 & 14 & 5 & 13 & 9 & 8 \\
\hline Other & 15 & 20 & 30 & 19 & 23 & 21 \\
\hline Developing countries & 1,484 & 1,531 & 1,770 & 2,034 & 1,899 & 2,160 \\
\hline Countries of former SFRY & 966 & 967 & 1,061 & 1,219 & 1,253 & 1,167 \\
\hline Bosnia and Herzegovina & 189 & 338 & 383 & 549 & 649 & 654 \\
\hline FYR of Macedonia & 63 & 73 & 70 & 59 & 77 & 64 \\
\hline Slovenia & 712 & 556 & 608 & 611 & 506 & 432 \\
\hline Other and unclassified & 2 & $\cdots$ & $\cdots$ & 0 & 21 & 17 \\
\hline Countries of the former USSR & 173 & 176 & 185 & 172 & 198 & 201 \\
\hline Other developing European countries & 158 & 192 & 229 & 191 & 223 & 247 \\
\hline Czech and Slovak Republics & 11 & $\ldots$ & $\ldots$ & $\ldots$ & $\ldots$ & $\ldots$ \\
\hline Czech Republic & 13 & 34 & 36 & 40 & 46 & 39 \\
\hline Hungary & 54 & 68 & 71 & 55 & 49 & 52 \\
\hline Poland & 37 & 45 . & 49 & 56 & 47 & 46 \\
\hline Slovakia & 8 & 16 & 21 & 22 & 22 & 22 \\
\hline Other & 35 & 29 & 52 & 17 & 59 & 88 \\
\hline Developing Middle East countries & 19 & 14 & 39 & 64 & 11 & 79 \\
\hline Developing Asian countries & 59 & 28 & 60 & 54 & 30 & 21 \\
\hline Developing countries of North Africa & 22 & 22 & 33 & 39 & 29 & so \\
\hline Developing other African countries & $\$ 5$ & 71 & 115 & 270 & 130 & 343 \\
\hline Developing countries in the Americas & 33 & 61 & 48 & 24 & 24 & 51 \\
\hline Developing countries of Oceania & 0 & 0 & 0 & 0 & 0 & 0 \\
\hline
\end{tabular}

Source: Central Bureau of Statistics.

1/ Data have not been revised in line with the 1998 balance of payments compilation methodology. Includes trade with countries of the former SFRY. 
Table 62. Croatia: Imports by Origin, 1993-98 1/

(In millions of U.S. dollars)

\begin{tabular}{|c|c|c|c|c|c|c|}
\hline & 1993 & 1994 & 1995 & 1996 & 1997 & 1998 \\
\hline Total & 4,666 & 5,229 & 7,510 & 7,788 & 9,104 & 8,383 \\
\hline Developed countries & 2,952 & 3,525 & 5,300 & 5,262 & 6,261 & 5,823 \\
\hline EU countries & 2,630 & 3,096 & 4,664 & 4,625 & 5,412 & 4,980 \\
\hline Austria & 311 & 353 & 575 & 597 & 709 & 612 \\
\hline BeIgium & 47 & 55 & 85 & 100 & 96 & 110 \\
\hline Denmark & 16 & 31 & 51 & 48 & 62 & 61 \\
\hline France & 97 & 116 & 188 & 199 & 293 & 401 \\
\hline Italy & 882 & 994 & 1,366 & 1,421 & 1,705 & 1,500 \\
\hline Netheriands & 92 & 115 & 174 & 176 & 170 & 161 \\
\hline Germany & 991 & 1,110 & 1,509 & 1,602 & 1,841 & 1,616 \\
\hline Sweden & 60 & 81 & 148 & 117 & 147 & 109 \\
\hline Great Britain & 90 & 179 & 455 & 225 & 189 & 176 \\
\hline Other & 44 & 62 & 113 & 139 & 200 & 234 \\
\hline EFTA countries & 86 & 112 & 219 & 179 & 244 & 231 \\
\hline Norway & 5 & 8 & 44 & 27 & 21 & 39 \\
\hline Switzerland & 79 & 101 & 169 & 144 & 213 & 181 \\
\hline Other & 2 & 3 & 6 & 8 & 10 & 11 \\
\hline Other developed countries & 235 & 317 & 417 & 457 & 605 & 612 \\
\hline Australia & 5 & 5 & 9 & 17 & 12 & 11 \\
\hline Japan & 42 & 54 & 80 & 104 & 139 & 146 \\
\hline Canada & 10 & 19 & 12 & 17 & 49 & 18 \\
\hline U.S.A. & 124 & 172 & 201 & 213 & 266 & 278 \\
\hline Turkey & 9 & 16 & 28 & 27 & 31 & 26 \\
\hline Other & 45 & 50 & 88 & 79 & 108 & 133 \\
\hline Developing countries & 1,714 & 1,705 & 2,210 & 2,526 & 2,844 & 2,560 \\
\hline Countries of former SFRY & 773 & 572 & 850 & 866 & 942 & 953 \\
\hline Bosnia and Herzegovina & 14 & 4 & 8 & 63 & 137 & 156 \\
\hline FYR of Macedonia & 46 & 27 & 36 & 34 & 42 & 56 \\
\hline Slovenia & 712 & 541 & 805 & 769 & 756 & 722 \\
\hline Other and unclassified & 1 & $\ldots$ & $\cdots$ & $\cdots$ & 7 & 19 \\
\hline Countries of the former USSR & 261 & 254 & 224 & 253 & 498 & 407 \\
\hline Other developing European countries & 235 & 210 & 473 & 571 & 640 & 572 \\
\hline Czech and Slovak Republic & 52 & $\ldots$ & $\cdots$ & $\ldots$ & $\ldots$ & $\ldots$ \\
\hline Czech Republic & 42 & 92 & 147 & 207 & 208 & 181 \\
\hline Hungary & 78 & 100 & 158 & 193 & 239 & 212 \\
\hline Poland & 25 & 38 & 45 & 50 & 59 & 63 \\
\hline Slovakia & 24 & 53 & 78 & 84 & 81 & 65 \\
\hline Other & 14 & 27 & 45 & 38 & 53 & 50 \\
\hline Developing Middle East countries & 3 & 16 & 44 & 106 & 186 & 85 \\
\hline Developing Asian countries & 284 & 364 & 213 & 301 & 213 & 217 \\
\hline Developing countries of North Africa & 64 & 91 & 236 & 269 & 169 & 106 \\
\hline Developing other African countries & 37 & 15 & 24 & 17 & 21 & 64 \\
\hline Developing countries in the Americas & 57 & 81 & 145 & 143 & 174 & 155 \\
\hline Developing cotntries of Oceania & 0 & 0 & 0 & 0 & 0 & 0 \\
\hline
\end{tabular}

Source: Central Bureau of Statistics.

1/ Data have not been revised in line with the 1998 balance of payments compilation methodology. Includes trade with countries of the former SFRY. 
Table 63. Croatia: Exchange Rates and International Reserves, 1996-99

\begin{tabular}{|c|c|c|c|c|c|c|c|}
\hline & & \multicolumn{2}{|c|}{ HRKUSS } & \multicolumn{2}{|c|}{$\mathrm{HRK} / 100 \mathrm{DM}$} & \multirow{2}{*}{$\begin{array}{c}\text { Real Effective } \\
\text { Exchange Rate } \\
\text { (Jan 1994=100) } 1 /\end{array}$} & \multirow{2}{*}{$\begin{array}{l}\text { Foreign Exchange } \\
\text { Reserves of the CNB } \\
\text { (In millions of } \\
\text { U.S. dollars) }\end{array}$} \\
\hline & & e.0.p & p.a. & e.o.p & p.a. & & \\
\hline \multirow{12}{*}{1996} & Janutary & 5.5 & 5.4 & 370.8 & 370.5 & 98.8 & $1,845.2$ \\
\hline & February & 5.4 & 5.4 & 369.1 & 370.1 & 98.8 & $1,883.6$ \\
\hline & March & 5.5 & 5.5 & 370.0 & 369.6 & 98.1 & $1,890.8$ \\
\hline & April & 5.6 & 5.5 & 365.5 & 368.8 & 97.1 & $1,876.3$ \\
\hline & May & 3.6 & 5.6 & 360.9 & 363.6 & 98.5 & $1,919.2$ \\
\hline & June & 5.4 & 5.5 & 357.6 & 359.1 & 99.7 & $2,019.1$ \\
\hline & July & 5.3 & 5.4 & 355.7 & 356.1 & 100.6 & $2,216.3$ \\
\hline & Angust & 5.3 & 5.3 & 355.1 & 354.7 & 101.3 & $2,331.1$ \\
\hline & September & 5.4 & 5.3 & 356.2 & 355.6 & 100.5 & $2,295.1$ \\
\hline & October & 5.4 & 5.4 & 356.6 & 356.3 & 101.5 & $2,312.5$ \\
\hline & November & 5.5 & 5.4 & 356.2 & 356.5 & 99.3 & $2,292.5$ \\
\hline & December & 5.5 & 5.5 & 356.2 & 356.0 & 100.1 & $2,314.0$ \\
\hline \multirow{12}{*}{1997} & January & 5.85 & 5.68 & 356.3 & 356.2 & 100.6 & $2,273,1$ \\
\hline & February & 6.04 & 5.96 & 357.3 & 356.7 & 100.0 & $2,177.8$ \\
\hline & March & 5.99 & 6.06 & 357.5 & 357.3 & 99.9 & $2,252.4$ \\
\hline & April & 6.20 & 6.11 & 358.0 & 357.5 & 99.5 & $2,208.1$ \\
\hline & May & 6.08 & 6.09 & 356.8 & 357.3 & 99.3 & $2,271.9$ \\
\hline & June & 6.17 & 6.16 & 357.0 & 356.8 & 99.3 & $2,326.5$ \\
\hline & Iuly & 6.56 & 6.37 & 356.6 & 356.9 & 98.5 & $2,326.2$ \\
\hline & August & 6.38 & 6.55 & 355.1 & 355.9 & 99.3 & $2,442.4$ \\
\hline & September & 6.24 & 6.34 & 354.5 & 354.7 & 100.1 & $2,487.8$ \\
\hline & October & 6.06 & 6.22 & 352.6 & 353.4 & 100.1 & $2,527.1$ \\
\hline & November & 6.23 & 6.10 & 352.7 & 352.4 & 101.1 & $2,515.6$ \\
\hline & December & 6.30 & 6.25 & 351.1 & 352.1 & 101.7 & $2,539.0$ \\
\hline \multirow{12}{*}{1998} & January & 6.42 & 6.37 & 351.7 & 351.5 & 103.2 & $2,404.1$ \\
\hline & February & 6.38 & 6.38 & 352.8 & 351.9 & 104.2 & $2,424.6$ \\
\hline & March & 6.49 & 6.44 & 352.2 & 352.9 & 104.6 & $2 ; 457.6$ \\
\hline & April & 6.43 & 6.47 & 357.6 & 355.8 & 102.4 & $2,481.2$ \\
\hline & May & 6.47 & 6.39 & 363.0 & 360.1 & 101.5 & $2,538.6$ \\
\hline & June & 6.60 & 6.51 & 364.1 & 363.4 & 100.6 & $2,550.0$ \\
\hline & July & 6.41 & 6.54 & 362.6 & 363.6 & 100.1 & $2,597.5$ \\
\hline & August & 6.44 & 6.44 & 360.2 & 360.3 & 101.4 & $2,745.2$ \\
\hline & September & 6.17 & 6.22 & 368.4 & 364.7 & 102.1 & $2,757.3$ \\
\hline & October & 6.17 & 6.08 & 373.6 & 371.5 & 99.9 & $2,696.9$ \\
\hline & November & 6.36 & 6.27 & 373.6 & 373.4 & 99.4 & $2,674.7$ \\
\hline & December & 6.25 & 6.24 & 374.0 & 373.9 & 99.5 & $2,815.6$ \\
\hline \multicolumn{8}{|c|}{1999} \\
\hline & January & 6.48 & 6.32 & 377.7 & 375.3 & 99.7 & $2,610.1$ \\
\hline & February & 6.87 & 6.67 & 386.9 & 382.6 & 98.0 & $2,396.3$ \\
\hline & March & 7.09 & 6.98 & 388.4 & 388.6 & 96.6 & $2,450.8$ \\
\hline & April & 7.16 & 7.09 & 388.1 & 388.5 & 96.9 & $2,413.1$ \\
\hline & May & 7.26 & 7.14 & 388.2 & 388.1 & 95.9 & 2583.9 \\
\hline & June & 7.34 & 7.31 & 388.4 & 388.3 & 97.4 & $2,610.1$ \\
\hline & July & 7.10 & 7.35 & 388.1 & 388.3 & 97.8 & $2,755.0$ \\
\hline & August & 7.26 & 7.14 & 388.0 & 387.9 & 98.0 & $2,847.4$ \\
\hline & September & 7.25 & 7.25 & 390.2 & 389.4 & 99.1 & $2,815.8$ \\
\hline & October & 7.32 & 7.13 & 390.7 & 390.5 & $\ldots$ & $2,993.2$ \\
\hline & November & 7.57 & 7.39 & 391.6 & 390.8 & $\ldots$ & $2,826.0$ \\
\hline
\end{tabular}

Source: Cmatian National Bank.

1/ Real effective exchange rates are calculated relative to seven currencies using retail of consumer prices. An increase in the rato denotes a real appreciation. 
Table 64. Croatia: External Debt, 1993-98 1/

(In millions of U.S. dollars, unless otherwise stated)

\begin{tabular}{|c|c|c|c|c|c|c|}
\hline & 1993 & 1994 & 1995 & 1996 & 1997 & 1998 \\
\hline Total debt stock, including short-term credits & 2,942 & 3,282 & 3,921 & 4,615 & 6,427 & 8,062 \\
\hline Total debt stock, excluding short-term credits & 2,942 & 3,282 & 3,919 & 4,611 & 6,420 & 8,062 \\
\hline Medium- and long-term loans & 2,332 & 2,655 & 3,018 & 4,256 & 5,979 & 7,051 \\
\hline Official sector & 1,142 & 1,292 & 1,423 & 1,866 & 1,855 & 1,970 \\
\hline International organizations & 315 & 399 & 487 & 672 & 851 & 975 \\
\hline Government sector & 827 & 893 & 936 & 1,194 & 1,005 & 996 \\
\hline Paris club & 772 & 821 & 864 & 993 & 843 & 886 \\
\hline Other & 56 & 72 & 72 & 201 & 162 & 110 \\
\hline Private sector & 1,191 & 1,363 & 1,595 & 2,390 & 4,123 & 5,081 \\
\hline London club & 941 & 993 & 1,000 & 1,462 & 1,428 & 1,405 \\
\hline Other commercial banks & 152 & 223 & 353 & 671 & 2,283 & 3,031 \\
\hline Suppliers & 98 & 148 & 242 & 256 & 412 & 646 \\
\hline Non allocated debt $2 /$ & 433 & 368 & 391 & $\cdots$ & $\cdots$ & $\cdots$ \\
\hline Interest arrears $3 /$ & 127 & 222 & 302 & $\cdots$ & $\cdots$ & $\cdots$ \\
\hline London club & 36 & 51 & 55 & $\cdots$ & $\cdots$ & $\cdots$ \\
\hline Paris club & 91 & 170 & 247 & $\cdots$ & $\cdots$ & $\cdots$ \\
\hline Bonds 4/ & $\cdots$ & $\cdots$ & $\cdots$ & $\cdots$ & $\cdots$ & 645 \\
\hline Short-term debt $5 /$ & 50 & 37 & 208 & 355 & 441 & 366 \\
\hline Short-term credits & 0 & 1 & 2 & 5 & 8 & 0 \\
\hline \multicolumn{7}{|l|}{ Memorandum iterns: } \\
\hline External debt to GDP ratio $6 /$ & 26.5 & 23.1 & 21.7 & 23.2 & 31.9 & 37.1 \\
\hline Short-term debt in percent of gross reserves & 8.0 & 2.6 & 11.0 & 15.3 & 17.4 & 13.0 \\
\hline Official debt to GDP ratio & 10.3 & 9.1 & 7.9 & 9.4 & 9.2 & 9.1 \\
\hline Private sector debt to GDP ratio & 10.7 & 9.6 & 8.8 & 12.0 & 20.5 & 23.4 \\
\hline Short-term debt to GDP ratio & 0.4 & 0.3 & 1.1 & 1.8 & 2.2 & 1.7 \\
\hline Dollar GDP & 11,116 & 14,235 & 18,081 & 19,871 & 20,109 & 21,752 \\
\hline Gross reserves & 616 & 1,405 & 1,895 & 2,314 & 2539 & 2816 \\
\hline
\end{tabular}

Sources: CNB and IMF staff estimates.

1/ Excludes non reported principal payments

2/ Debt contracted by the former Socialist Republic of Yugoslavia, for which responsibility was assumed by Croatia as part of the London and Paris club restructuring agreements of 1995--96.

3 / These arrears were subsequently restructured into principal as part of the London and Paris club restructuring agreements of 1995-96.

4/ Data for bonds prior to November 1998 was recorded as medium and long term loans

5/ Does not include short term trade related debt with maturities of less than three months.

6/ Excludes short term credits. 